IINIVERSITY OF CALIFORNIA, SAN DIEGO

LA JOLLA, CALIFORNIA

\section{DATE DUE}

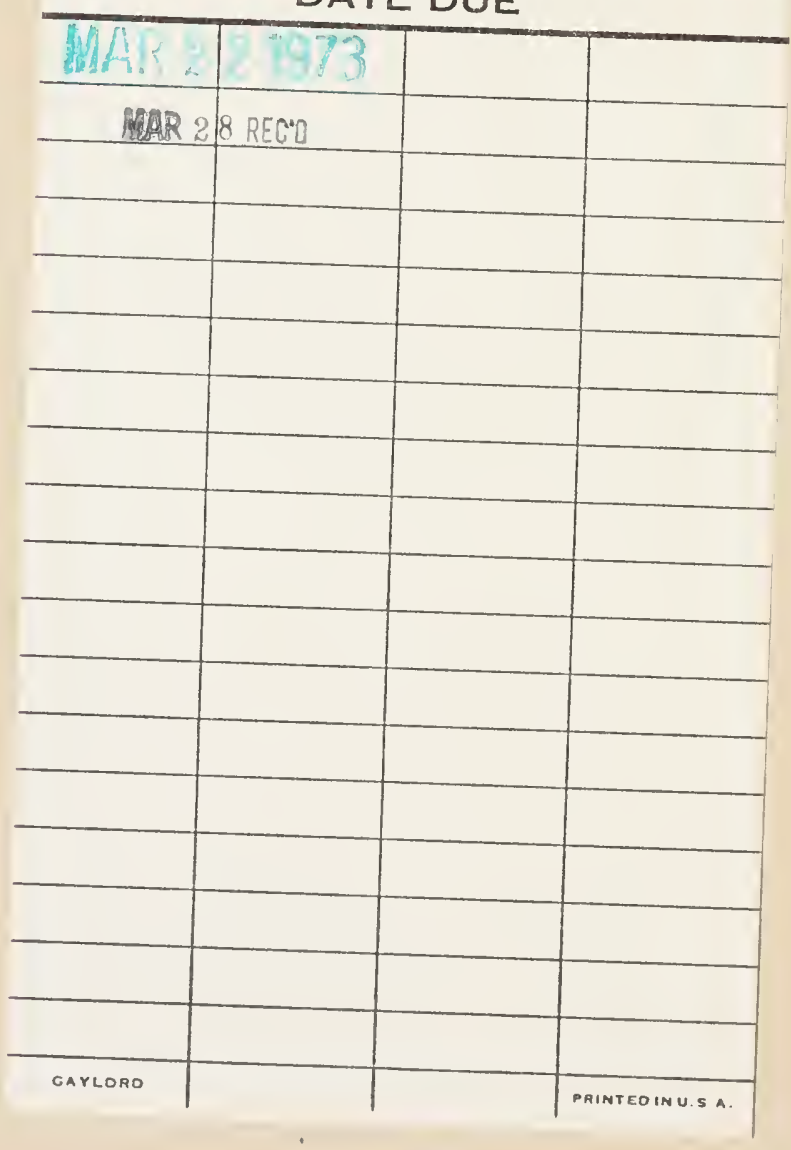


Digitized by the Internet Archive in 2008 with funding from Microsoft Corporation 


\title{
AROUND the WORLD
} via INDIA $=$

\author{
A MEDICAL TOUR
}

BY

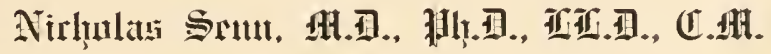

Professor of Surgery Universty of Chicago-Professor and Head of the Surgical Department Rusb Medical College-Surgeon-in-Chief Sit. Foseph's Hospital-Attending Surgeon Presbyterian Hospital

-Surgeon General of Illinois-Lieutenant Colonel and Chicf of the Operating Staff ivith the Army in the

Field During the Spanisb-American $U$ 'ar, etc. 

$\begin{array}{lllllll}P & R & E & F & A & C & E\end{array}$

Tbis book is more especially intelioes for my protesslonal

frienos wbou II bave met ourting my travels in oiffer= ent parts of tbe worlo, and to wbom II am cbiefly il = sebtes for many courtesics and mucb intormation. $\tau$ bc tert consigts of a series of articles publisbeo in Tbe Fournal of tbe fmerican Miscoical $\mathfrak{z}$ seociation ouring tbe lagt six montbs of the vear past. Mallouew illus= trations bave becll aoded wbicb the alltbor bopes will enbance tbe valuc of tbe book

N. SENN

Chicago, June 15,1905 



\section{ONTENTS.}

Tratel as a Means of Post-Graduate Medrcal liduca-

PAGE.

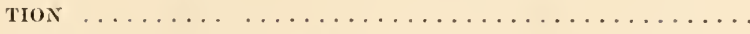

leprosy in the Hawaind Islands: The Proposed Establishment of a Government Baeteriologic InstituteSegregation-A Fighting Leper-The Leper Settlement on the Island of Mlokai-A Government Baeteriologic Laboratory and Station for the Seientifie Study of Leprosy-The Island of Molokai as a Home for Lepers....

Fathel Daniex, the Leper Hero: A Heroie Brother-The

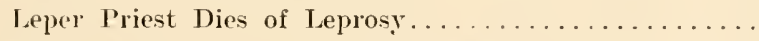

IIEdCal AfFars ix tile Hawaiax Islaxds: Historieal Sketel of the Islands-Climate-Native PopulationPrevailing Diseases-Ihe Medieal Profession-Queen's Hospital-Medieal Society of the Hawaiian lerritory.

Gur lossession ix Samoa from a Medical Standpoint: Sketeh of the History of the Islands of Samoa-Our Samoan Island-Climate-The People--Present Form of Government-Kava Drinking-Native Houses-Diseases - Hospitals .......................

XEW ZeAlaxd: The Oeean Voyage-Climate-NativesAnckland-Anckland Hospital-Medieal Profession....

Iustialia: The Kangaroo-Climate-Prevailing Diseases -People-Natives-The Mika or Kulpi OperationSurviving Aborigines-Sydney-Hospitals-Sydney Hospital-Royal Prince Alfred Hospital-Medieal Profes. sion $\ldots \ldots \ldots \ldots \ldots \ldots \ldots \ldots \ldots \ldots \ldots \ldots \ldots \ldots \ldots \ldots \ldots \ldots \ldots \ldots$

The Melbourne Hospitals: The Melbourne HospitalRadical Cure for Inguinal Hernia-Prostateetomy-Alfred Hospital-Melbourne Hospital for Siek ChildrenSt. Tincent's Hospital-A Trip to the Giant Euealyptus Trees

The Adelaide Hospitals: The Adelaide Hospital-Adelaide Children's Hospital-Gallstone in ElephantsPristuortem on a Zelna Private llospitals in Australia - Terrace IIospital-Clareton Hospital 
Medical Education in Australia: Sydney University anel Medical Sichool-Melbomrne University and Medical School-Arelaicle University and Medical School..... 155

CEYLox: From Anstralia to Ceylon-Island of Ceylon; Its Climate. People; Prevailing Diseases-Soysa Bacteriologic Institute, Colombo The General Civic HospitalCeylon Medical College-Leper Asylum at HendalaLeper Buddhist Celebration-City of Kandy-The Anmul Budlua Celebration-Botanical Garden-Kandy General Ciric Hospital . . . . . . . . . . . . 167

Ixpra: Madras Mealical College-Jress, for Natives Only - Madras fovermment General Hospital-Carcinoma in Indial-Alscess of the Liver-Aneurism of Common ant External Cirotid Arteries-Hydatid Cyst of Tibia-Rhinoscleromi ........................... 197

Bengal Medical College: Female Certificate ClassThe fimmomye Hostel-Military l'upil Class-Midwives and Dias ................... 13

Galenta Govermment Gineral Hospital: The ('ity of latipm and Mayo Hospital; Splenic Anemia-l'iroplasma Donovani . . . . . . . . . . . . . . . . . . . . 229

Grant Medieal College and the Hospitals of Bombay: Pathologic Mnsemus-Pnemonic Plague-syphilitie Fibrosis of the Lung-Anewrism of the lleart-Hepatic Abscess-Enormous Calculus of the Bladder-Ainhum of the Small Toe-Myretoma or Madura Foot-Anesthetie Leprosy-Guinea Worm-Jamsetjee Jeejeebhoy Hospital - Prevalent Diseases-Homeless Leper Asylum, Batunga -The Plague Researcli Laboratory of the Government of India, Jarel-Pombay Bubonic Plagne Flospital-A Cobra Den-Calmette's Antivenene ............. 247

Fonr Thousand Miles Through India by Rail in Mid-l1mmer: Attractions of India-Master and ServantIndian Summer Climate-The People-Inelian Art-Notable Medicinal Trees of India-Benares Nonkey Temple-1 Benares Saint-Hindn Cremation-Taj MahalDelhi-A Parsee Woman Doetor-A Siek Elephant-A Crocodile Tank-A Belated Bridal Ceremony-Feast of the Sew Moon-A Faithful Roman Catholic PriestElephanta Caves-A Grewsome Chamel House........ 


\section{L L U S T RATIONS.}

TiLitiRE

PAGE.

1. Tuberenlar Jeprosy in a Joung Native Girl. . . . 2.23

2. Tubercular Leprosy in a Hawaiian ............ 24

3. Inland of Molokat . . . . . . .

4. Anesthetic Leprosy in a Native Woman.......... 27

j. Baldwin Home for Lejer Boys, Kalawao, Mőokai... ¿s

6. Father Damien .................. 3]

7. Kalawao Leper Settlement. Nolokai, Established by the IIawailan Govermment in 186.s. Showing Also Father damiens Chureh ............. 35

s. Father Damien's Grave ............... 4 l

9. Natives and Native House................. 47

10. Lnan, National Hawaiian Feast .............. 49

11. The Govermment House, Honolulu ............ 51

12. Queen Emma, Consort of King Kamehameha III... 53

13. Quen's Hospital, Honolulu, Established by King Kamehameha III and Queen Fuma in $1860 \ldots \ldots . .5 . j$

14. Tutuila, Samoa, U. S. Naval Station...........63

15. Flag-raising Ceremonies ................ 6.5

16. Samoan Women and Child ...............67

17. Tamasese, Fine Specimen of Samoan............ 71

18. A Native of Tutuila Affected with Elephantiasis Affecting All Extremities ............... 75

19. Native Hospital in Pago Pago, Tutuila ......... . 79

20. Swa Dance in Tutuila, July 4, 1904, in Front of Naval

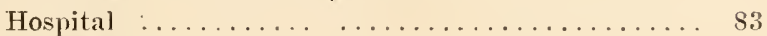

21. Maori Women .................... 89

22. Auckland Hospital .................. 95

23. Australian dborigines ................. 110

24. Aborigines of Central Australia in War Dress....... 111

25. Young Native Mother and Infant............. 115

26. The University of Sydney, Overlooking Victoria Park. 119

27. The Original Medical School, University of Sydney. . 120

28. View of Sydney Hospital from the Northwest...... 121

29. The Operating Theater. Sydney Ifospital. . . . . . . . 12.

30. Adelaide Hospital .................... 141

31. View on the Grounds; Adelaide Childrens' Hospital.. 149

32. Medical Sehool University of Sydner............. 161 
FIGURE.

33. A Singhalese . . . . . . . . . . . . . . 175

24. Singhalese Woman . . . . . . . . . . . . . . . 179

35. Leper Asylum at Hendala . . . . . . . . . . . . . 189

36. Tooth of Buddah ...................... 191

37. Madras Medical College and Government General Hospital ....................... I9s

38. Another View of Madras Medieal College and Government Gelleral Hospital................... I99

39. Chondrosareoma of Humerus and Scapula......... 203

40. Bengal Medical College, Caleutta............... 213

41. Quarters for Military Pupils ............... 215

42. Eden Hospital, Calcutta ................ 221

43. Elephantiasis of Legs .................. 223

44. An Undiagnosed Case ................... 225

45. Native of Jaipur .................... 230

46. Hindu Dancing Girl ................... 231

47. Piroplasma Donovani ................. 243

48. A Parsee ............................ 249

49. Anatomy Building, Grant Medical College ......... 251

50. Madura Foot ....................... 257

5 I. Feloid of Punctured Lobe of Ear .............. 259

52. Operating Room, Jamsetjee Jeejeebhoy Hospital. . . . . 261

53. Hindı Snake Charmer ................. 273

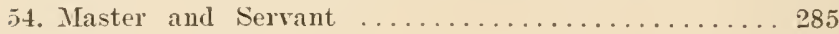

55. Hindu Butler ...................... 287

56. In Indian Faquir ................... 295

57. An Arab Jew in India ................ 297

s. Hindu Women ........................ 301

59. A Sikh Priest .................... 305

60. Low Caste 1Iindu Girls................... 307

61. An Illustration of Hindu Architecture............ 311

62. The Colonnade in the Hindu Temple at Rameshwaran. 313

63. Open Air Cremation.................... 317

64. Swani Bhaskara Nand Saraswati, the Famous Ascetic of Benares ...................... 320

65. Taj Mahal ....................... 321

66. Tower Dear Dethi .................. 325

67. City of Delhi .................... 327

6. Sative Policemen ................... 331

‘9. Botanical Garden, Calcutta............... 337

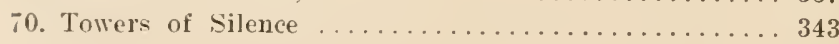


TRAVER IS I MEATS OF POST-GRADUTAE IIEITES EI)LCITIOA.

For the second time I am on a tour aromed the world -this time in an opposite direction. from Eart to West, via India. I leave San Francisco on the steaner sierra. July $\%$, and if I am spared the disease-producing etlects of the tropical climate and not delayed by failing to make timely comnections, I expect to reach New York on the Kromprinz Withelm, October 11 . Three years ago I girdled the globe via Siberia in three months and twenty days. That trip was replete with information of all sorts, general and professional, and the pleasure of it was enhanced by the companionship of my friends, Prof. D. R. Brower and Drs. Mastin and Frank.

I am very well aware of the fact that midsummer is the wrong time to undertake a journey through India, owing to the intensity of the heat, but I expect to receive at least a partial recompense for the expected sufferings incident to unfavorable climatic conditions by aroiding crowded hotels, cars and steamers, which so often detract from the pleasures and benefits of travel during the winter season. when the tourists elbow their way over this popular pathway around the world. This, at least, was my experience in visiting the Holy Tand and Egypt during the summer months on a former occasion.

Beside, the duties of my college work are such as to preclude all possibility of seeing India at the most desirable time. My friends who had comtemplated mak- 
ing this long jonlney with me have all, one after the other. decided otherwise. so I shall find myself alone for once from one end of the world to the other. This isolation also has its adrantages and charms. 'The time will be'ong to me exclusively and I shall dispose of it in the most profitable mamner in studying the different places of greatest interest, the people, their customs and habits. I shall also devote special attention to matters pertaining to our profession and report from time to time to the readers of 'THE Jourxal the results of my observations. Experience has taught me that in traveling in tropical countries the best means to counteract the banchef effects of heat is work. mental and phy-ical. It is mnder the influenee of prolonged heat that inadivity begets mental and physical languor. while exercios of body and mind increases the force of the enfecbled circulation and stimulates the organs of sccretion and excretion to greater activity. Before leaving the Pacific Coast I desire to discuss rery briefly the snbject indicated by the title of this, my first communication. and in doing so I fully realize what Cicero said of letter-writing:

"Te write ditlerently when we think that those only to whom we write will read our letters, and in a different style when our letters will be seen ly many."

- My prospective letters mean letters to the over 31,000 subscribers of the official organ of the American Medical Association, many of whom I count among my most estcemer and intimate friends, hence my diffirlence and uneasiness in beginning.

From time immemorial travel has been recognized as an important element in acquiring a general education and in obtaining proficiency in the professions, arts, sciences and trades.

It is the study of men and mamer. in different clines and varying social and political conclitions that proves so useful in enlarging the views of life and 
weighing its posibilitios. Horatios was fully aware of this whem ho wrote:

"The knowledge of men and mamor's is the first principle and fomtain head of good writing."

before machincry usurped the place of hand labor mechanies and tradesmen acquired their technical knowledge by serving as appentices for a number of vears under the supervision of an acknowledged master, and after having obtained the required proficiency they spent another year or two, their Wanderjahre. in traveling from place to place in perfecting themselves in their rocation by familiarizing themselves with the practical work of different masters, before they considered themselves fully qualified to take their independent stations in life. In this manner they acquired a reliable knowlvilge of the detail of their work, which no one master could impart. If travel and observation and practice uncler different masters in the acquirement of a thorough knowledge of the different trades are such important factors of snceess in the world of business, it must appear very evident that the same means are even nore desirable and efficient in the stndy of medicine and in keeping pace with the wonderful adrancements and improvements of the most progressive of all professions. In this age of research and discoveries, the science and the practice of medicine and surgery are molergoing revolutionary changes from lay to day. and the ceascless search for truth and facts makes it necessary for the molern practitioner to keep abreast with the latest and best pertaining to his calling.

In our day this means much. It was not so in the remote past, when the anthority of writers of popular text-books remained unchallenged for centuries. We live in an age characterized by progressivencss. deep scientific investigation, free and sharp criticism. Theories advanced by one are overthrown by another unles: they stand the erucial test of successful repetition by 
acknowledged leaders in the profession. What was new yesterday may become old and obsolete to-morrow. Scientific work is no longer confined to a few favored institutions; it may be seen in all parts of the civilized globe. Nations and institutions are now enciged in a laudable competition to excel in blazing new pathways through the still unexplored territories of scientific medicine. It is by the concerted, systematic, scientific inrestigation of disease in all climes and under varying conditions that we must look for more radical measures in the prevention and more successful treatment of disease. There is no time in the life of a medical man when he feels more confident and competent to battle successfully with disease and perform the most difficult operations than on the day he leaves his alma mater. diploma in hand. ready to seek his place in the crowded ranks of his future profession. If the new aspirant for a liberal patronage is honest, it will not take him long to discover his shortcomings and crave for more knowledge. He will be made painfully aware of the fact that

\footnotetext{
"Because all the sick do not recover, therefore medicine is no art."-Cicero.
}

The completion of the study of medicine, even in the best equipped medical colleges and universities, furnishes at best but the foundation for the subsequent post-graduate education. If the foundation is firm and the building material contributed later substantial and in sufficient abundance, the resulting structure will resist fire. wind and storm. a lasting monument to the builder. If the foundation is defective and the building material not of the right sort, failure and disappointment will surely follow misdirected efforts, no matter how earnest and persistent they have been. The successful physician and surgeon will be the one who, with the day of his graduation. enters on a rational, well-planned. systematic post-graduate comrse of 
the study of medicine and its allied sciences. 'T'his constitutes a life sudy. Without it the practice of medicine incritably soon degenerates into a miserable tracle. 'The reading of new text-books and the best current medical literature, passive and active work in medical socicties, local, national and international, laboratory work in the office and local hospitals, are well calculated to meet the needs of the ambitious, conseientions practitioner, but thcy will not suffice in giring him the best possible opportunitics to keep in touch with the spirit and practice of the extraordinary age in which we live. Reading and seeing are two entirely ditferent things. 'The eye is the great educator in technics of all kinds. It is one thing to read the description of a eomplicated operation; it is another thing to see it performed by the hands of a master. 'Textbooks, valuable as they are, are but poor substitutes for actual instruction and demonstrations in elinical and laboratory methods. Personal intercourse with prominent men in the profession imparts a stimulation for more earnest and more effective efforts not obtainable to the same extent in any other way.

A personal acquaintance with men who have carned a well-merited reputation in the advancenent of our profession is a source of great gratification and excites a new interest in the work he has accomplished. 'The study of strange diseases in distant countries fills a gap which a college education and subsequent reading can not fill. An aceurate knowledge of elimatic conditions and their effects on health and disease can only be acquired by travel.

For the professional man, and especially for the physician, travel opens a field of learning and affords opportunities the importance of which can not be overestimated. In order that travel may rield the desired results, both physically and mentally, it must be carefully planned and properly conducted. The demands 
on the time and energies of an exacting, laborious practice are such that fatigue. bodily and mental, must follow sooner or later. Of all learned professions the medical is the one in greatest need and most deserving of a long, free-of-care annual vacation. It is hard to make the public believe this, but it is nerertheless true. During the summer months the complicated mechanism of the law comes to a standstill and the lawyers take their racation without crippling their bank acconnt to any considerable extent. The fashionable churches close their doors when the members of the congrega. tions leave for their luxurious summer homes, and the rectors and preachers, with purses well filled with gold by their appreciative parishioners for their vacation expenses, leave the great cities and spend their allotted leisure weeks and months where ther are sure to find rest, comfort and recreation. It is the physician who is expected to work from one end of the year to the other, ready for call by day and night, in sunshine and storm. It is the phrsician whose annual income suffers when he leares his practice for a much-needed outing. It is the physician who carries away with him the weight of his responsibilities to a greater extont than the members of any other profession when away from daily routine work. The public must be made to understand that medical men are entitled, above any other profession or class of men, to an annual racation, and that such racation, properly spent, will bring to their patients better service, and will be one of the most important factors in promoting the science of melicine. public hygiene and sanitation.

Where and how shall the physician spend his vacation?

"Travel, in the younger sort, is a part of education; in the elder, a part of experience."-Bacon.

The phrsician who has the interests of his patients and profesion at heart will not be content, like most 
professional and business men, to spend his precious vacation time in idleness at some fashiouable seashore or mountain resort or to imbibe the questionable plear-ures of city life. The working time of a profussional carcer is too short to waste time by idleness or dissipation. Rest to him means work of the right kind. What wears a busy doctor out is not the physical work he does, but the care and sense of responsibility it carries with it. The greatest pleasure to him is to see others work, and the sweetest rest a freedom from care. Brain fatigue is more frequently caused by care, real or imaginary, than overwork. A man in average health can do an incredible amount of congenial work. lut it is care that furrows the face and blanches the hair prematurely.

Relieved of care the physician on his vacation is in the best possible mood to reap the benefits of the work of others near and far. The visits to laboratories. hospitals and museums, the personal contact with colleagues in different countries, the inspection of new instruments, the practical work in the operating room and laboratory will become to him fascinating and instructive object lessons. The genuine feeling of fraternity among medical men throughont the entire world will insure to the earnest and honest seeker of knowledge a most friendly reception, provided the risitor conducts himself properly. The American, born in a land where the idea of equality among men is pre-eminent, in order not to give unintentional offense, must adapt himself to the customs of the countries he visits, and thereby secure the good will and friendship of those whose work he is privileged to see.

In Europe the matter of titles conferred by the governments on medical men is confusing to the American visitor. Fortunately our forefathers guarded against anything reminding one of royalty to take foothold on our soil. In Furope and any of the European possessions and Japan a titled person must he recognized and 
treated as such. The title of professor there means much more than with us, for the reason that it can not be made use of without being granted by the government. A professor must, therefore, not be addressed as doctor, as is customary in our country, where the freshman medical student does not hesitate to make use of this common and familiar term in addressing his teachers, and if he comes from some rural district, where physicians are too familiar with their clients and neighbors, he may be bold enough to shorten the word to "inc."

As soon as a European professor is honored by a government title he has a decided preference for the latter, hence. if he is a Lord, Sir, Excellency. Geheimrath, Baron, Pasha, Bey, etc., he expects to be addresserl by the titles with which he has been honored.

Another thing the traveling physician should always be mindful of, and that is not to pester the teacher or operator with unnecessary questions. Many of these men we meet are very busy, and their temper is sometimes rufled by overwork. The assistants, less burdened with responsibilities. alo always glad to give the required information if approached properly and at an opportune time. The firing of questions, often of an irrelevant nature, at a busy, orerburdened professional man, is in exceedingly bad taste, and can hardly fail to excite his displeasure. The plysician away from his cares and strenuous duties should not undertake to teach or to instruct, but should devote all available time to add to his knowledge by seeing. hearing and rearling. The visiting physician must become a woll-squeezed sponge, ready and eager to absorb, slow in offering artvice and in exhibiting his operative skill. The display of technical skill in strange hospitals and elinics shonld be discouraged, as the operator labor's muler the great disarlvantages of doing his work with unfamiliar instruments and strange assistants, and for these and other olvious reasons can not do himself and his patient jus- 
tice. 'The traveling post-graduate medical student, unless he intemds to devote considerable time to laboratory work, should not remain at any one place for any length of time. It does not take long to become familiar with methods of teaching and details of operative technic. It is more profitable, and certainly more interesting. to see ten men operate ten times each than to see any one man operate a hundred times. 'Travel, as a mreans of post-graduate medical education, does not necessarily imply that the time should be spent in great medical centers, as is too often the case. Some of the very best medical and surgical work is now being lone beyond the shadows of medical sehools and great metropolitan hospitals. We often learn more of the real merit of a surgeon who is thrown entirely on his own resonrces in some remote, small, isolated city, whose instrmment supply is limited, assistants few and perhaps incxperienced, than when we witness the operations by recognized masters in the palatial hospitals, supplied with everything that modern surgery could possibly sug. gest, and assisted by a large staff of well-trained, experienced resident surgeons.

In our comntry and abroad magnificent little hospitals are being built in the smaller cities and large villages in which the patients receive excellent nursing and the very best medical and surgical service. Some of these places in our own country have recently become famous for the excellency of the surgery practiced. Among these Rochester. Minn., and Oshkosh. Wis., deserve special mention. The Mayo brothers at Rochester control the lion's share of the surgery of the West, and their hospital in the little prairic city of not more than 5,000 inlabitants has become a Meeca for the surgeons not only from this country but from albroad. There is no other hospital on this side of the Atlantic in which so many important operations are performed daily as in this one. It would be rifficult for any one to visit St. Mary's Hospital, Oshkosh, a city of 30,000 
inhabitants, in which Dr. C. IV. Oriatt toes his surgical and gynecologic work, and find him perform less than three or four major operations, any day of the year. These are by no means isolated instances; there are many other comparatively small cities in which the traveling physician will find excellent phrsicians and surgeons from whose example and practice he will carry away many new ideas, suggestions and hints of scientific and practical importance. The elinical teacher is not necessarily the best phrsician or surgeon, as much of his time and talent are consumed for the benefit of his students. It is the man with a solid, scientific foundation, endowerl with a keen, practical sense, studions and deroted to his work. who generally seores the greatest success. Travel from place to place has this one great advantage, that the traveler does not become one-sirled nor too much influeneed by the riews and practice of any one man. The traveler must know how to discriminate. what to reject and what to alopt. We often learn more from shadows than light and from mistakes than a correct techie. The privileged visitor must be slow in criticism and grateful for the opportunities he is giren to familiarize himself with methods emplored by men in rarious parts of the world. Let him trarel from place to place. cultivate the personal acquaintance of his professional colleagues near and far and learn from them all he ean and remember that

\footnotetext{
"The nse of traveling is to regulate the imagination by reality. and instead of thinking how things may he, to see them as they are."-Tohnson.
}

Many men with brilliant minds and endowed with the purest and noblest ambitions to sneceed in their calling fail in reaching the intender mark becanse they did not keep in touch with the ontside world. In the practice of medicine isolation is a dangerous thing becanse it engendors a routine practice from which it is impossible to escape in late attempts. The olserration o? the work of others, the interchange of ideas and ex- 
periences constitute a course of post-graduate education which can not be supplanted by the greatest diligenee in reading and hard laboratory work. 'The young loctor should take short vacations, and with advancing age the length of vacations and scope of travel should increase. Away from trouble, free from care, the wandering plysician will find between his hospital risits, laboratory investigations and musem studies most profitable opportunities to dip deep into the great and inexhaustible book of nature. I can hardly conceive of a physician who loves and values his profession who should not take the deepest interest in medical geography and everything that pertains to it. The physician can not help making man, muder the most varying conlitions, climatic and social, a life study. He can not resist the allurements of the vegetable and animal kingdom under most diverse conditions of climate and soil. Iway from the bedside and operating room, out of reach of the moaning, of the suffering and. the anxious faces of the parents and friends of the aftlicted, l.e will instinctively turn to the more pleasant phases of life and study and admire the wonderful works of the Supreme Creator of all things, animate and inanimate. Away from toil the sun will appear to him brighter, the stars nearer and more brilliant, the flowers more beantiful, the foliage and sward greener, the song of birds more cheerful, the babbling of brooks more gentle and the language of the talking ocean sweeter than when eve and ear are engaged by the afflictions of his suffering clientele. Tet the overbmrdened, careworn physician remember when away from care and anxiety

"We place a happy life in tranquility of mind." - Cicero.

San Francisen, July $7,1904$. 



\section{LEPIOSY IN THE HAIIAIIAN ISLANDS.}

THE IROPOSEA ESTABLISIIMENT OF A GOYEITMENT B.AC-

TERIOLOGIC TNSTITUTE.

The inhabitants of the beautiful Hawaiian Islands, comparatively free from the devastating infectious diseases so long as they enjored the blessings of isolation from the outside world, have been made painfully aware of the dangers of the dissemination of disease from man to man. They have experienced the benefits and blessings as well as the evils and curses arising to them from a new civilization brought to their palm-clad shores by white men in seareh of new lands and fabulons wealth. Some fifty years ago the first case of leprosy came to the little island kingdom from the distant Orient. As usual with the primitive peoples of the islands of the South Seas, this dreadful disease found a fertile soil in the natives, with so little resistance to all infections diseases, acute or chronic. It spread with alarming rapidity. and it became evident unless rigid measures were enforced in the way of ahsolute and early segregation, that from this cause alone, the entire population would become practically extinct in less than half a century. In 1866 the number of known lepers had reached 105 ; in $1876,6 \% \%$; in 1886.590 : in $189 \%$, 1.100 , and when I visited the Molokai settlement two years later I found that the number of leper had reached 1,300. When I visited the islands a second time I was informed that the number of lepers. owing to the fearful mortality among them, had been reduced to 1,100 . The nationalities of the lepers is shown by a report made in 1898, of which number $98 t$ were natires, 62 half eastes, 32 Chinese, and 5 Americans. 
SEGREGITION.

When it was found necessary to enforce segregation a commission was appointed to select the most favorable location, climatic and otherwise, for the unfortumate exiles. This commission acted wisely in selecting a tongue-like projection of the island of Molokili, isolated on two sides by the ocean and from the remaining part of the island by an almost perpendicular cliti, the Pali, 2,000 feet in height, which is crossed by those who are permitted to visit the settlement over a shelf-like path hewn ont of the solid rock. A trip over such a mountain path demands much physical exertion, and more than an ordinary interest in making the visit. The laws regulating and enforcing segregation are more stringent here than anywhere else. They include a divorce of married people if the man or wife so desire, and exclusion from society for the remainder. of the leper's life. If the healthy husband or wife is willing to share the fate of the doomed consort she or he is permitted to share the banishment, with the understanding that the cxile is for life, and with no expectation of ever coming in tonch with remaining relatires again, this side of eternity. On the other hand, the exiled man or woman is tree to marry again, an inmate of the leper settlement. 'The government recognized that what certainly appear as hard, and even cruel, measures, were intended for the benefit and protection of the mass of the population. That these severe laws met first with violent opposition on the part of the lepers and their rlevoted relatives and friends is very natural, among a people who are very unselfish and affectionate. The officers were intrusted with carrying the laws into effect. The physicians who made the diagnosis and the police who had to apprehend the suspeets and attend to their transportation to the settlement met with many difficulties, and in some instances -nstained personal violence. 


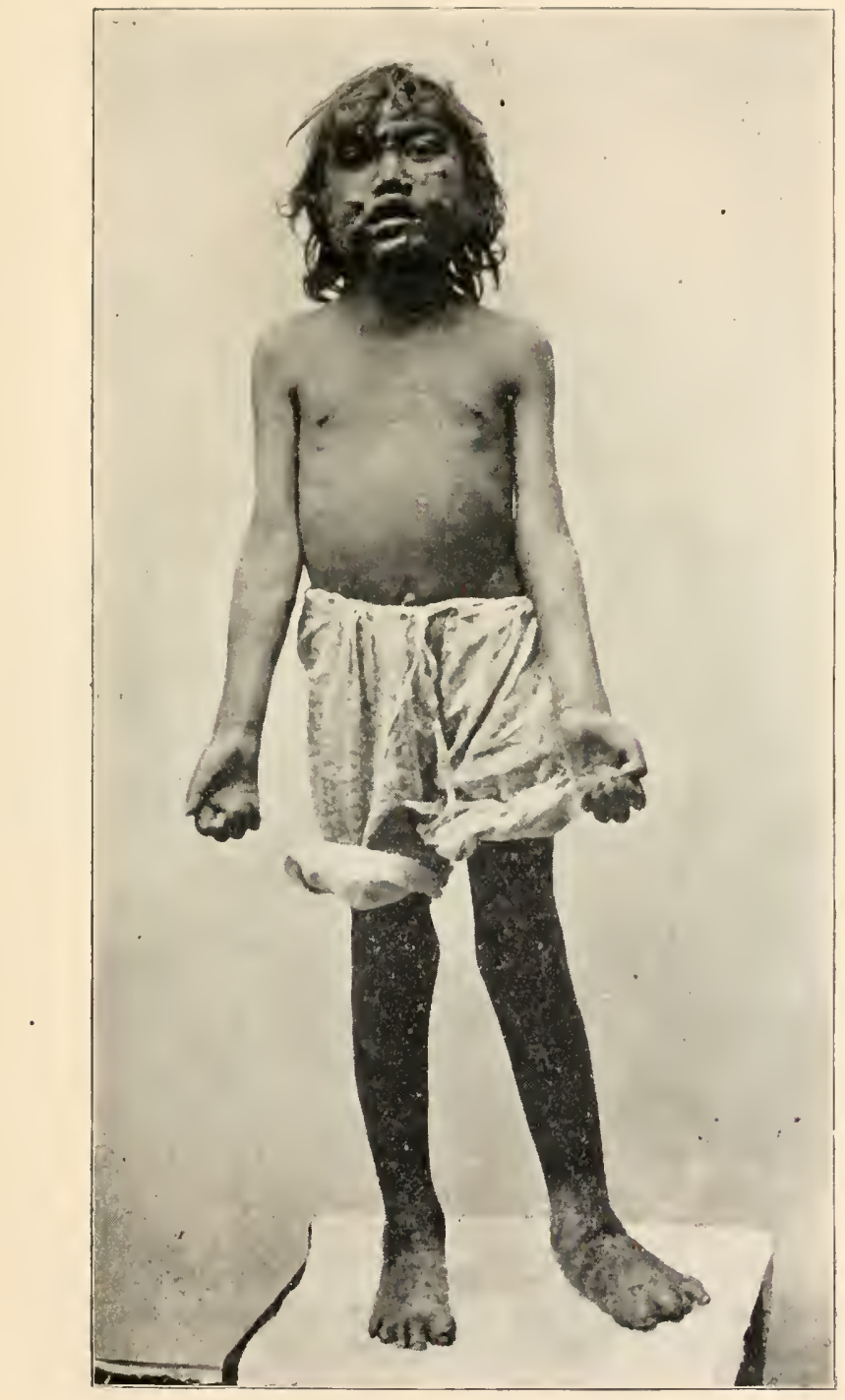

Fig. 1.-Tubercular leprosy in a young native girl. 


\section{A FIGIITING LEIER.}

There is one instance on record where a leper resisted not only the police force but an entire company of infantry. He hid himself in a mountain care, accompanied by his faithful wife, the only access to which was orer a narrow path, whene men had to walk in sin-

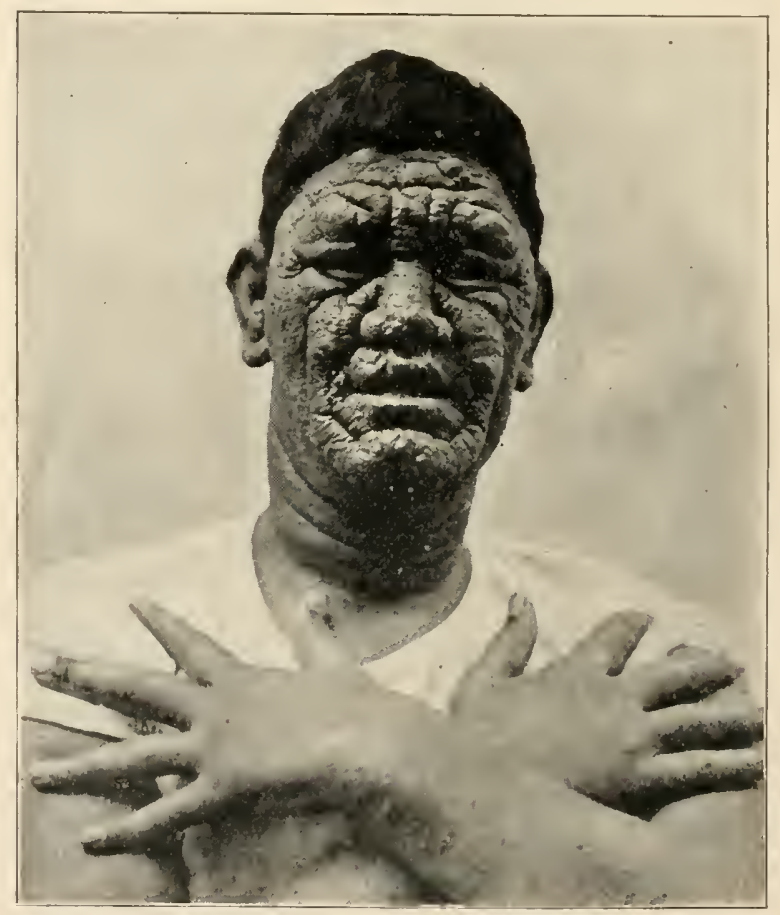

Fig. 2.-Tubercular leprosy in a Mawaiian.

gle file. He supplied himself with firearms and ample ammunition. and declared that anyone who came within range of his gun would be killed. When the soldiers were sent to secure him he only did what he had threatened, and killed the first four who headed the file. The attempt was never repeated, and the lesperate leper had the satisfaction of being relieved of sufferings in his 
lonely care, beine ared lor by his decoted wile. Just when he died and where his mutilated body found its last resting place no one knows, as lis wife took the preaution to hide his remains in some lonely mountain place, to protect it from being interfered with. and her rflorts. so far, have been successful.

THE I.EPER SELPLEMENT ON THE ISLAND OF MOLOKAI.

The leper settlement is made up of two rillages, on opposite sides of the promontory. From the very beginning the unfortmate inhabitants of this strange and idnal settlement have been treated in the kindest and most humane manner. Under royal rule, when the

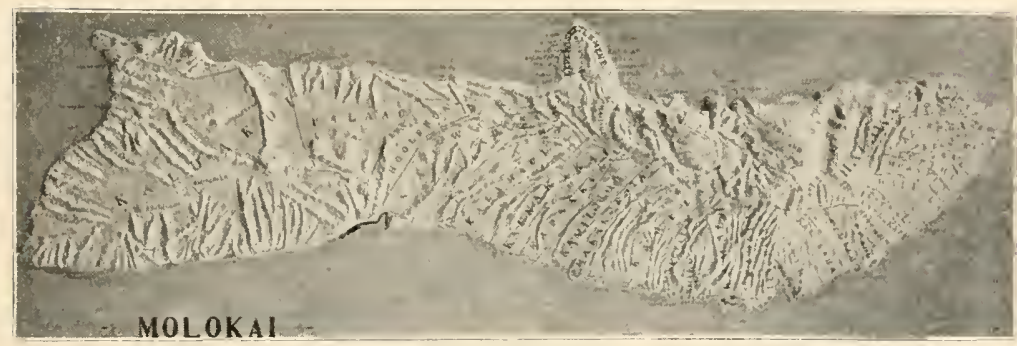

Flg. 3.-Island of Molokal.

islands formed a republic, and now under a territorial form of gorernment. large sums of money. on an arerage $\$ 100,000$ a year, have been spent to procure all possible comfort. The settlement has churches, schoolhouses, stores, and even places of amusement. 'The lepers live in little homes, to many of which a pleasant garien spot is attached. This parental care on the part of the government. and the home life are what have removed all opposition to segregation. Lepers now seek artmission to the settlement of their own accord. It wonld be difficult, and. I think. impossible to find a place better adapted by nature for such a purpose. The rquable climate all the year around, the cooling, refreshing land and sea hreezes. the surf baths, the ahmo- 
ance of salt-water fish. the excellent water supply and matmral serrerage adrantages furnish conforts and conditions. by nature and man, that could not be found anywhere else.

A GOTERAMENT BACTERIOLOGIC LABORATORT AND STATION FOR THE SCIEXTIFIC STUDY OF LEPROSY.

The gorernment owes an important duty in furnishing protection to its citizens against infections diseases. To the physician leprosy still remains a strange, mysteriou disease. We know its microbic cause, we have become somewhat familiar with its pathology. we are powerless in euring it, or even in retarding its ravages and relentless course. I successful treatment must and will be found. There is no other place in the world where more effective work conld be done. The leper: are here. They are a docile. gentle people, who will heartily co-operate with a scientific man to find the much-neederl remedy. The annexation of the Hawailan Island places this great field of scientific research within easy reach of the United States. Tittle Tapan has placed a small colony of lepers and sufficient funds at the disposition of the distinguished Professor Kitasato to discorer a remedy for millions of people scattered all over the world. Why can not the rich and enterprising goverument of the United States embrace this great opportunity to find a remedy for such a loathenme and hopeless discase like lepra. With the aequisition of island possessions in the Pacific and Atlantic the danger of the spread of the disease in our own country is being rastly inereaser. Let the United States take care of the leper settlement at Molokai, spend $\$ 100,000$ in the erection of a laboratory for the study of leprosy. pay a recognized scientist at its head with a salary of $\$ 10.000$ a year. and thus place itself in line with other conntries. which are now doing what they can on a mnch smaller scale in hringing leprosy within range as a curable diseasp. Hawaii would hai] such a step with 
joy to be relieved of the heary ammual cxpense in earing for its leper children, and in co-operating with the general govermment in seientific research, calculated to lead to the discovery of a cure for a discase. so widely sprearl, and which has proved itself so obstinate to all kinds of tratment so liar suggested and tried, and

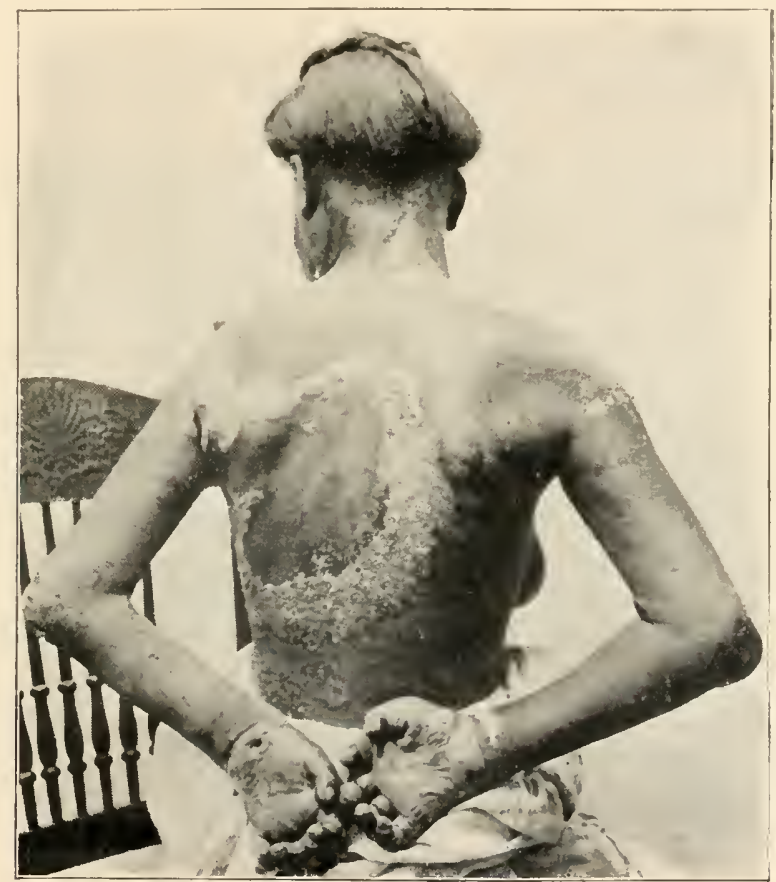

Fig. 4.-Anesthetic lemrosy in a native woman.

against the dissemination of which stern exile has been the only means. The time is ripe for the United States to act. Let the mass of the American medical profession agitate this matter and let the delegates of the territory bring it to the attention of om energetic and humane congress and such prompt action is sure to bring about the desired result. 
THE ISLAND OF MOLOKAI AS A HOME FOR LEPERS.

As can be seen from the accompanying small sketch of the island of Molokai (Fig. 3), the leper settlement occupies only a very little of it. It seems to me that in view of the many lepers that will come under our charge it might be advisable to devote the whole island of Molokai to homes for lepers. There is only one limited tract of land, owned by Mrs. Meyer and her children, which is of any considerable money value. The balance of the island could be bought very cheaply. The

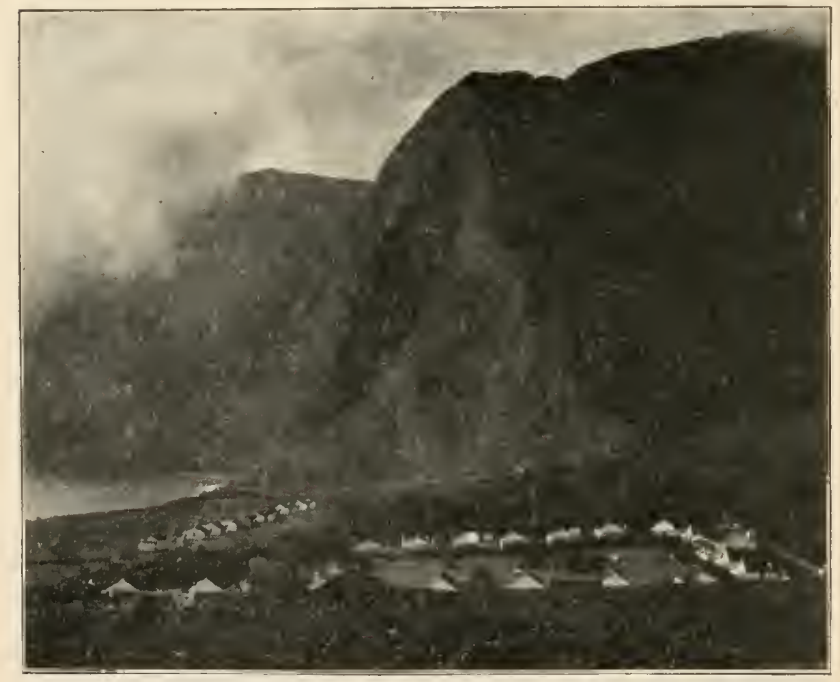

Fig. 5.-Baldwin Home for leper boys, Kalawao, Molokal.

Hawaiian lepers should remain where they are, but the remaining part of the island could be readily converted into pleasant homes for lepers from the states and colonies. The entire island is large enough for colonies representing different nationalities, which conld be established sufficiently far apart to guard against international friction. It would not be difficult to locate pleasantiy 3.000 additional lepers on the opposite shore and monntainous part of the island. This suggestion is worthy of consideration.

I[oxolite. July 14. 1904. 


\title{
FATHER DAMIEN, THE LEPER HERO.
}

\author{
"Yothing is more delightful than the light of \\ truth."- (icero.
}

There are heroes and heroines, men and women, who in times of danger do not hesitate to sacrifice their lives in attempts to save others. Heroism consists in acts of moelfishness and courage of the highest type, under conditions of impending danger. or calling for a degree of self-sacrifice from which the average mortal instinctively sluinks. Untimely death and self-imposed deprivation of the comforts of life for the benefit of others who are in danger or distress exact from heroes the highest and noblest qualitics of man-undaunted courage, unselfish charity and unconquerable love, and boundless hmmanity toward mankind. Such a combination of the highest virtnes is, indeed, rare, and when fomblentitles the hero to the profomnd respect, highest almiration and permanent gratitude of all nations. and morc especially the one benefited by his sacrifices. The world looks to the battlefield as the arena for the exhibition of heroism in its truest, grandest and nobiest sense. Military heroism has from time immemorial been immortalized in song and prose. Heroism in war signifies conrage and patriotism, but lacks humanity and the grcatest of all virtnes, charity. The soldier knows that his brarery will be recognized, and that, in the event of his survival, he may confidently expect that a grateful nation will reward him for lis raliant services.

Sudden, painless reath in the heat and tumult of battle is. in itself, an honor, a sufficient inducement for many to seck it when imbued with the justness of the cause for which they fight and stimulated by the fire of a borning patriotism. Heroism in the cause of 
humanity, stripped of the excitement and glories of war, brings out the best attributes of man. Heroism rendered at the altar of humanity. with no expectation of renown or reward, among the sick and dying, under conditions attended by vastly more danger to life and health than the risks of war, gives testimony of the highest type of a hero or heroine.

Such a hero was Father Damicn, the subject of this sketch. During his life devoted to the welfare of exiled lepers, his motives were often misunderstood and his noble soul experienced many a pang when he was maligned, as was not infrequently the case. We can say of him:

"Glory comes too late when paid only to our ashes."-Martialis.

Father Damien is no stranger to the medical profession (Fig. (i). His heroic labors among the banished. maimed and disfigured lepers of Molokai, and his glorious death from the discase he fought so courageously, have made him a hero in the estimation of the medical profession and in the eves of the entire world-a hero whose name will live long after the disease he fought and from which he died will have become extinet. As a humanitarian, his memory will go down to the future side by side with that of Henri Dumont; as the leper hern. it will never die. The whole life of Father Damien from the cradle to the grave was an exemplary one, and his work was characterized by unselfishness and an ardent devotion to his manifold and trying duties. How it was possible that statements to the contrary conld bave been made during his lifetime is a mystery that admits only of one explanation-he, like nther great men, had enemies whose envy was aroused by the marrelous sncees in everything he attempted. His entire career as a priest and friend of the lepers breathes a spirit of true, earnest Christianity which those who knew him best nerer qnestioned. The malicions attacks on his character were made by men who 


were too cowardly to visit the leper settlement and observe his work among the thousand unfortunates whose pains he soothed and to whose spiritual needs he ministered with an unparalleled zeal and untiring derotion, whose dying he consoled, and whose dead he buried in coffins and graves often made by his own hands. Is a true minister of the gospel, he served his God and leprous congregation with a devotion and faithfulness that knew no limits, by day and night, in sunsline and storm.

Father Damien's name in the world was Joseph de Veuster. He was born at Tremelo, near Louvain. Belgium, Jan. 3, 1840. His parents were honest, hardworking, devout peasants, who raised a family of seven children, four of whom entered the service of the church-his older brother, Pamphile, and two sisters. The earliest desire of his boyhood was to become a priest, in which rocation his older brother preceder? him. The parents being poor, he struggled with the greatest difficulties to realize his desire. He finally entered the College of the Fathers of the Sacred Hearts of Jesus and Mary, and entered holy orders at the age of 19. The splendid health which he enjoyed throughout his long student life was gained during his boyhood days, spent in hard work on the farm. The cloister life made him abstemious, and he exhibited an irresistible attraction for the rigors of austere penance. Early piety and a tender affection for his parents. as shown in all his letters, laid the foundation for a successful priestly carcer. When he entered the cloister he was the very embodiment of health, strength and activity. Endowed with great mental power and applying himself closely to his studies, his progress was rapid, and when he left the institution he was well prepared for his chosen life work. Although serious. he was not ascetic. In a letter to his parents during his theological studies, in commenting on the uncertainty of life, he says: "The thought of the uncer- 
tainty of to-morrow must, no doubt, cause bitter grief to a sinful soul, but for us, Christians or religious, who look on ourselves as exiles here below, and who long only for dissolution of our body that we may enter our true country, there is, it appears to me, only joy and blessedness in the thought that each moment we get nearer to the last hours of our life." His splendid health. his lore for an abstemious life, and especially his burning desire to serve his Lord and his church where he could accomplish the most, awakened in him during his early novitiate dars an ardent desire to consccrate himself to missionary work in the islands of the Pacific. I have no doubt but that this desire was often included in his daily prayers. The prayer wis answered sooner than he possibly could expect. Mgr. Maigret. ricar-apostolic of the Hawaiian Islands, made a request for sisters and brothers to assist him in his missionary work. His brother, Pamphile, was sclected, but took typhoid fever, and Damien begged to take his place. He was then only in minor orders, but the request was granted. What a source of pleasure it must have been for young Damien to learn that he was permitted to enter on work in one of the roughest of the Lord's vineyards so early in life! He made the long journey in a sailing ressel from Bremen to Honolulu around Cape Horn, and was ordained priest on his arrival, at the age of $2 t$. On foot and horseback, across mountains and valleys. from place to place, he brought to the natives the glad tidings of the gospel, and by his great modesty, genial manners and a willingness to assist them in their worldly affairs. soon won their confidence, respect and love. The name Kamiano, the Hawaiian for Damien, soon became a household word throughout the islands. His first station as priest was in Hawaii Island, but it was destined that his life should be sacrificed in the spiritual and worldly betterment of the unfortunate inhabitants of the leper settlement. Before Father Damien came to 
the settlement the govermment, after cstablishing segregation, only concerned itself in the temporal wellbeing of the unfortunate outcasts. The many Protestant ministers in the islands never dreamed of extending their work to where it was most needed. 'The Catholic Church, ever alert to enlarge its field of usefulness, and to reach the poor, miserable and unfortunate, and bring them within its fold, came to the resene of the leper outeasts. Occasional visits to the settlement to render the much-needed spiritual assist-

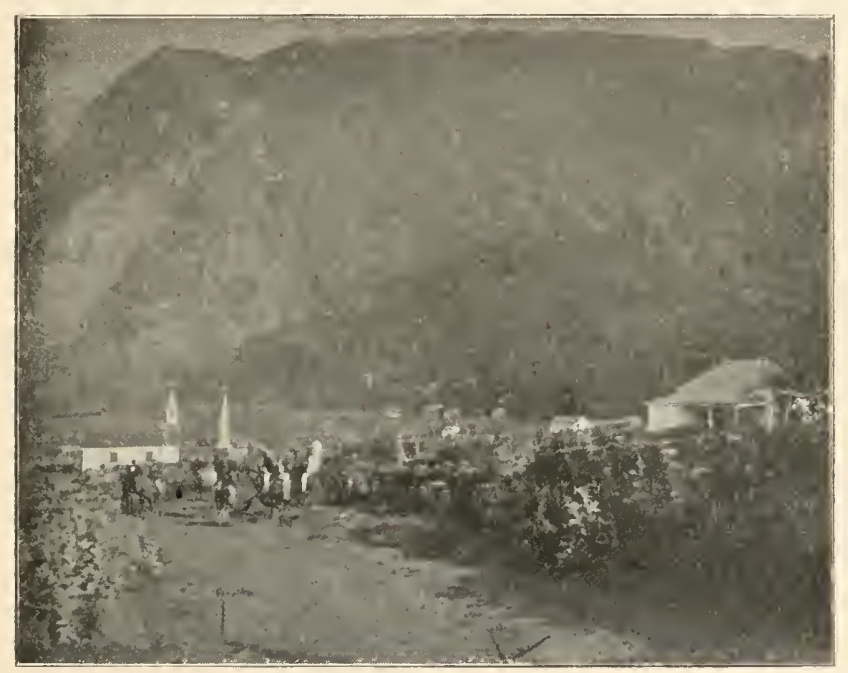

Fig. T.- Lalawao leper settlement, Molokai, established by the Hawaian government in 1865, showing also Father Damien's church.

ance were made by Fathers Ralymund, Albert and Bonsface from $18 \% 1$ to $18 \% 3$. A lay brother completed it little chmreh in 18\%3. At a meeting of priests held at this time in Maui, presided orer by the bishop, it was decided to supply the settlement with a resident priest. The bishop called for a volunteer. Every one of the three priests assembled was ready to serre.

Father Damien emphasized his claim for preference in the following brief, forcible speech: "My Tord, re- 
membering that I was placed under the pall on the day of my religious profession, thereby to learn that voluntary death is the beginning of a new life, here I am, ready to bury myself alive among these unfortunate people, several of whom are personally known to me." Sueh language could not fail in securing for him the cherished position. He sailed directly for the settlement, where he landed May 10, 1873, penniless, and even without a change of linen. The only arailable shelter he found to proteet him from rain and the burning rays of the sun was a hospitable pandanus tree, in the shadow of which he lived for some time. The very presence of this saintly priest had of itself a marrelous effect on the morals of the exiled. In a letter to his provincial two days after reaching the settlement he writes: "You know my disposition. I want to sacrifice myself for the poor lepers. The harvest is ripe." The heroism of this humble priest made a deep impression not only on the lepers, but the antire population of the islands. He eommenced work with a will. The time left between his priestly offices was oceupied in improving the worldly condition of his charges. Beside his clerical duties, he did the work of a earpenter, mason, gardener, ete. It is said that he made more than 1.500 coffins for his dead out of the rough boards furnisher by the government. On an average he officiated at 200 funerals a year, where lie often was priest and sexton at the same time.

He built little frame houses among them-one for himself, with only two small rooms. I found here a wooden bathtub made by himself which gave testimony to his skill as a carpenter. No leper ever entered this, the plainest of all houses in the village. A chair. table, bed and a few plain pictures representing Bible scenes and the life of saints, his saddle and bridle, well worn, and a frw religious books were about everything he left behind him at the time of his death. He built another church (Fig. ?), roing most of the work himself, 
and took great pleasure in rendering its interior attractive by the simplest but tasty decorations. He erected schoollionses and orphan asylums, established a choir and organized a music band, and placed them under the direction of his faithful helper, Brother Dutton. I listened to the music of this band playing national and sacred songs. Every member of the band was a leper; some had lost a number of their fingers, others played the cornet with lips half destroyed, ulcerated and distorted. It was a scene it wonld be impossible to forget. Father Damien became a physician and a druggist, and his place in these functions is now filled by Brother Dutton. Although the settlement had a resident physician at the time of my visit, the little but well-stocked dispensary was crowded with patient:, and Brother Dutton was busy in washing and dressing wounds and realing out simple remedies.

In describing leprosy, Father Damien writes to his brother: "Lepross, sn far as is known. is incurable. It seems to begin by a corruption of the blood. Discolored patches appear on the shin. especially on the checks, and the parts affected lose their. feeling. After a time this discoloration covers the whole body; these ulcers begin to open chicfly at the extremities. The flesh is eaten away and gives ont a fetid odor; even the breath of the leper becomes so foul that the air around is poisoned with it. I have had great difficulty in getting accustomed to such an atmosphere. One day at the Sunday mass I found myself so stifled that I thought I must leave the altar to breathe a little of the onter air, but I restrained myself, thinking of our Lord when $\mathrm{He}$ commanded them to open the grave of Lazarus, notwithstanding Martha's word, 'Jam foetet.' Now my sense of smell does not cause me so much inconrenience, and I enter the huts of lepers without difficulty. Sometimes, indeed, I feel some repugnance when I have to hear the confessions of those near the end, whose wounds are full of maggots. Often. 
also, I scarce know how to administer extreme unction, when both hands and feet are nothing but raw wounds."

Let those Protestant ministers who complain of small salaries listen to how Father Damien managed his financial affairs: "I hare not a penny of income-yet, nihil. mili deest. I want for nothing. I have even alms to give away. How is this to be explained? That is His secret, who promised to give a hundredfold to those who gave up all to Him." What better proof could be furnished of his childlike, Christian faith? When Father Damien took charge of the leper settlement he took a census and found that it contained 600 lepers, 80 of whom were very ill in the hospital. Vice ran high. The poor exiles sought solace in the excessive use of a domestic alcohol, held dances, and practiced card playing and sensualities of all kinds. This is the way in which Father Damien proceeded to improve the morals of the people: "Kindness to all, charity to the needy, a sympathizing hand to the sufferers and the dying, in conjunction with a solid religious instruction to my listeners, have been my constant means to introduce moral habits among the lepers." It is no wondre that under this kind precept and teaching the influence of Father Damien increased from day to day in improving the bodily and moral conditions of his people. Protestants, entirely neglected by their preachers, and non-believers, soon felt the effect of the religious teaching and example of the only spiritual adviser in the settlement and were not slow in embracing the Catholic faith. This is what one leper had to say of Father Damien, and he was only the spokesman for all: "We are especially satisfied with our pastor. He overwholms us with his solicitous care, and he himself builds our houses. When any of us is ill, he gives him tea. biscuits and sugar; and to the poor he gives clothes. He makes no distinction between Catholics and protestants." On the occasion of a visit of the princess regent to the settlement. one of the Honolulu papers, in re- 
ferring to Father Damiens work, emmmented on it in the following most beautiful language: "This young priest, Damien hy name, who has comsecrated his life to the lepers, is the glory and boast of Hawaii. He resuscitates the saintly heroism of the bloody arena of the ages of old-nay, he does even more. Wonld it not bes a greater laror to be thrown a prey to the wild beasts rather than to be condemned to live in the poisonous atmosphere of a leper settlement? And DamienDamien, the soldier of Christ-has lived now several years in the midst of the banished lepers of Molokai!" Are there any more witnesses to be heard to prore that the charges made against Father Damien by a jealous Protestant minister who never saw the leper settlement were utterly without foundation? I believe not, for "by their fruits ye shall know them." The spiritual and worldly care of the poor lepers remains to-day in the hands of devoted priests. brothers and sisters of the Catholic Church. I could not finish this brief sketch of the leper hero without referring briefly to one of his faithful co-laborers who shared with his master the heary burdens of the early missionary work, and who remains at his post to-day.

\section{A HEROIC BROTHER.}

During my visit to the leper settlement I became very much interested in a man of medimm size. spare build, dressed in a blue cotton suit decidedly the worse for long wear, a pair of cheap spectacles hanging loosely over nearly the end of a sharp-pointed nose. He was the master of the school for boys and leader of the band. His facial expression, bearing and attitude were enough to indicate that he was a tireless worker. It was Brother Dutton, so long associated with Father Damien in the care of the lepers. He showed us the different institutions, and spoke most enthusiastically. but in great modesty, of his work. In speaking of Father Damien tears filled his eyes and his lips trem- 
bled. He had not risited the little house in which Father Damien lived since his death, although separated from his school only by a narrow street. The man's whole soul seemed to be in his work, and I presume the great grief eaused by the loss of his beloved priest prevented him from entering the little house where they had spent so many hours together in consultation and prayer for fear of increase of mental anguish. Nobody knows the early history of his life. He never speaks of the past. It was rumored that he was disappointed in love during early life, but no proof to this effect has ever been furnished. It is known that he serred during the civil war, and that for gallant service he was promoted from the ranks to major. He was a Protestant. and joined the Catholic Church twenty-one years ago, and has been a most devoted member of that church since. A friend has this to say of him: "His superb sacrifice in going to Molokai was made from no weak or unworthy motive. He was supremely grateful to Almighty God for the gift of the true faith, and simply wished to make the best return in his power. and so, like the brave soldier he had long proved himself to be, he quietly made the decision to derote his life to the most laborious and, humanly speaking, the most distasteful charity in the whole range of the Catholic religion." Soon after Father Damien's death Brnther Dutton discorered some sores on his legs. He firmly believed he was suffering from leprosy, and was happy in the thought that in a short time he would have the great privilege to die of the same disease as his master and join him in heaven. The doctor's examination tnok away this hope, and he remains at his post, free from the loathsome disease after an uninterrupted service of twenty-three years.

How many faithful, deroted and unselfish servants the Catholic Church has! 
TIE LELEL TRIEST DIES OF IALIROSY.

When Father Damien left his native country he bade his relatires and friends good-bye with the firm conriction that he would nerer meet them again on earth. When he consecrated himself to the cance of the lepers lie did so with the expectation that he would sonner or later share the fate of his flock. It was his desire and hope that he might be spared for a long time for the benefit of the cause he had made his lifework. He took

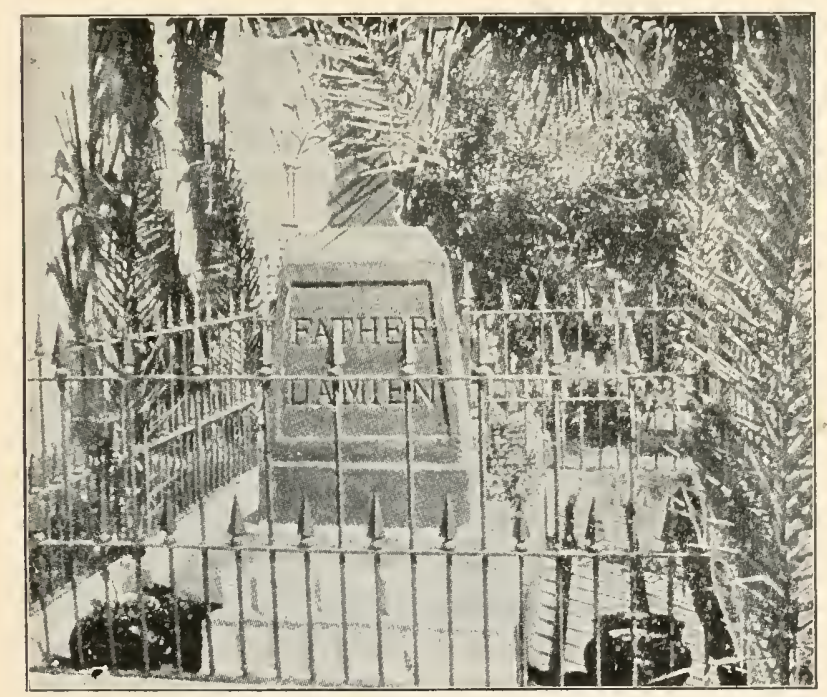

Fig. S.-Father Damien's grave.

every precaution to escape contagion by excluding the lepers from his house and by observing the utmost cleanliness of his person, and by inculcating the same as far as he could on the inhabitants of his leper villages. With all care, however, he could not escape the unusually prolific sources of contagion in performing his priestly functions, more especially in administering the sacrament and extreme unction. The manual labor of the roughest kind which he did for the lepers, to make them more comfortable, could not fail to produce 
frequently cuts, punctures and abrasions, by which the danger of inoculation was greatly increased. What he had feared occurred before he had expected it. After twelve ycars of ceaseless self-sacrificing toil among the lepers he discovered accidentally that he had himself become a victim of the terrible disease. In his sermons he always addressed his congregation, "We lepers." Now he conld say so in truth. In taking a foot bath one cvening in hot water he noticed that he had blistered one of his feet without having felt any pain. He knew only too well what this meant-the first symptom of the anesthetic form of leprosy. The physician who examined him later confirmed what had become to him already a conviction. In writing at this time to the bishop, he said: "From henceforth I am forbidden to come to Honolulu again, because $I$ am attacked by leprosy. Its marks are seen on my left cheek and ear, and my eyebrows begin to fall. I shall soon be completely disfigured. I have no doubt whatever of the nature of my illness, but. I am calm and resigned and very happy in the midst of my people. The good God knows what is best for my sanctification. I daily repeat from my heart, "Thy will be done." " It was very fortunate, indeed, that Father Damien contracted the macular instead of the tubercular form of the disease, and that the palmer side of fingers and hands remained clean, permitting him to perform his spiritual functions until a few days before his death, which occurred April 15, 1889.

So ended the precious life of one of the greatest benefactors of the human race-the hero of charity! The greatest heroism of Father Damien was exhibited during his illness, as he persisted in working with hand:and heart until a few days before his death. What could touch the human heart more than to see a leper priest render manual work and spiritual consolation to a congregation of lepers, the blind leading the blind, the lame supporting the lame! His heroic death has 
silenced the vile tongues. The surviving lepers can not be comforted; they will carry their grief over the loss of their faithful shepherd to their graves. The entire population of the Hawaiian Islands-in fact, the whole world-mourns his death. He has gone to his wellearned reward. His mangled remains sleep under the shadows of the pandanus tree which first sheltered the robust, devoted young priest awaiting a glorious resurrection. (Fig. 8.)

Volumes have been written in praise of Father Damien. Monuments have been erected to his memory, charitable institutions have sprung up to immortalize his heroic charity; but if that humble priest could speak to his admirers he would say, "I have only done my duty, praise God. Send greetings and extend a helping hand to my leper friends."

S. S. Sierra, July 1 .

\section{FATHER DAMIEN.}

$\mathrm{O}$ sing your requiems, waves and winds, On far-off tropic shore!

O mourn the Soldier of the Cross, Arms stacked forevermore!

The weapons forged in Love's fierce flame Of sacrifice untold!

And shining with the glittering gems Of abnegation's gold!

Dear Father, 'twas a lonely way, Where waves moaned on the shore, While with their wailings rose the cry Of suffering evermore.

Aye, lonely as the world defines The loneliness of soul,

But well we know the angels walked Beside thee to the goal!

Treading within the Savior's steps, And "doing all things well";

Letting the light of Christian Hope Shine through Despair's dark cell; 
So like thy Master, hands upraised

To serve and heal and bless,

While to His little ones you gave

The Father's pure caress.

Within that far-off tropic isle The twilight splendor glows

In dazzling hues for one brief space, And then as swiftly goes;

So thou when life was radiant with Thy splendid deeds of light,

Saw deepening shadows gather round And fold thee in Death's night.

But o'er the gloom of wind-swept grare, A star of beautr beams,

And through its rays, to all the world, Thy martyr's halo gleams.

While man remembers glorious deeds, Thy name shall live in light,

For never Soldier of the Cross Died in a nobler fight!

O sigh rom requiems, ocean winds,

Above the martyred one!

But clearer than your wailing rings

The Master's sweet "Well done!"

No grander, purer, nobler soul,

E'er waged the war of God.

Sleep on. O Soldier of the Cross,

Beneath the sea-girt sod!

Mari E. Griffin. 


\section{MEDICAT AFFAIRS IN THE IAWATIAN ISTANDS.}

The recent annexation of the Hawaiian Islands as a territory of the United States has awakened among us a new interest in their agricultural, commereial, professional and educational status. The wisdom of the consummation of such an act can not be questioned, as the United States has thereby gained a firm foothold in the Pacific Ocean at a point of great strategic importance and the islands have secured for themselves a permanent form of government and the most advantageous commercial relations with the outside world. The inhabitants will be made to feel that

"In no other state except that in which the power of the people is supreme has liberty any abode, than which nothing assuredly can be more delightful."-Cicero.

The islands have natural resources that must be made arailable to the natives. The rapid transitions from barbarism to a kingdom and from a kingdom to a republic and from a republic to a territory of the great republic have left the agricultural and commercial interests of the islands in an unsettled state, which, however. nuder the new arministration will soon be remedied. Since the foreigners have taken the reins of government in their hands prosperity and depression have followed each other at variable intervals of time, and the gains have found their way largely into the pockets of a favored few. It is to be hoped that under the new rule booms and depressions will gire way to a steady and more healthful growth of the undereloped resources in which the natives will reap their legitimate share. 
The scenic beauty of the Hawaiian archipelago is exquisite. The islands are of volcanic origin, mountainous, and clad with verdure and intersected by fertile valleys.

\section{HISTORICAL SKETCH OF THE ISLANDS.}

It is supposed that these gems of the Pacific Ocean became populated by the Polynesians from the distant Samoa Islands about the year 500 A. D. It is claimed that they were first seen by Juan Gaetano, a Spanish mariner, in 1555 , but as he left no record, either at home or on the islands, of his visit their discovery must be credited to Captain Cook, who sighted them in January, 17\%8, and named them Sandwich Islands, in honor of Lord Sandwich. On landing, the discoverer found them densely populated, the people peaceable, hospitable and extremely modest and courteous, as they prostrated themselves on his approach and remained in this humble position until he and his escort had passed, a courtesy they always extended to their chiefs. He found no indications of cannibalism, but human sacrifices, as in all the South Sea islands, were frequently offered. On his return from a voyage to the west coast of America the next year he was killed by the natives soon after landing at the island of Hawaii. at a place now indicated by a monument to the memory of the intrepid explorer. The killing of Captain Cook was provoked by a drunken brawl of his sailors, which incensed the natives, and their wrath centered on the leader of the expedition. His body was interred, and not eaten, as is so often claimed. The political condition of the islands under the rule of different chiefs, was a stormy one, wars between the different islands and tribes being frequent, until the Napoleon of the islands, Kamehameha I-born $1 \% 3 \%$, died on the island of Hawaii, 1819-after many bitter wars gained supremacy over all of the islands and ruled them in the capacity of a king. His reign was humane and wise. 
He abolished human sacrifice and introduced many other reforms most creditable to savage rule. With the death of Kamchameha $V$ the reigning family became extinct, and Kalakana was elected king. He died

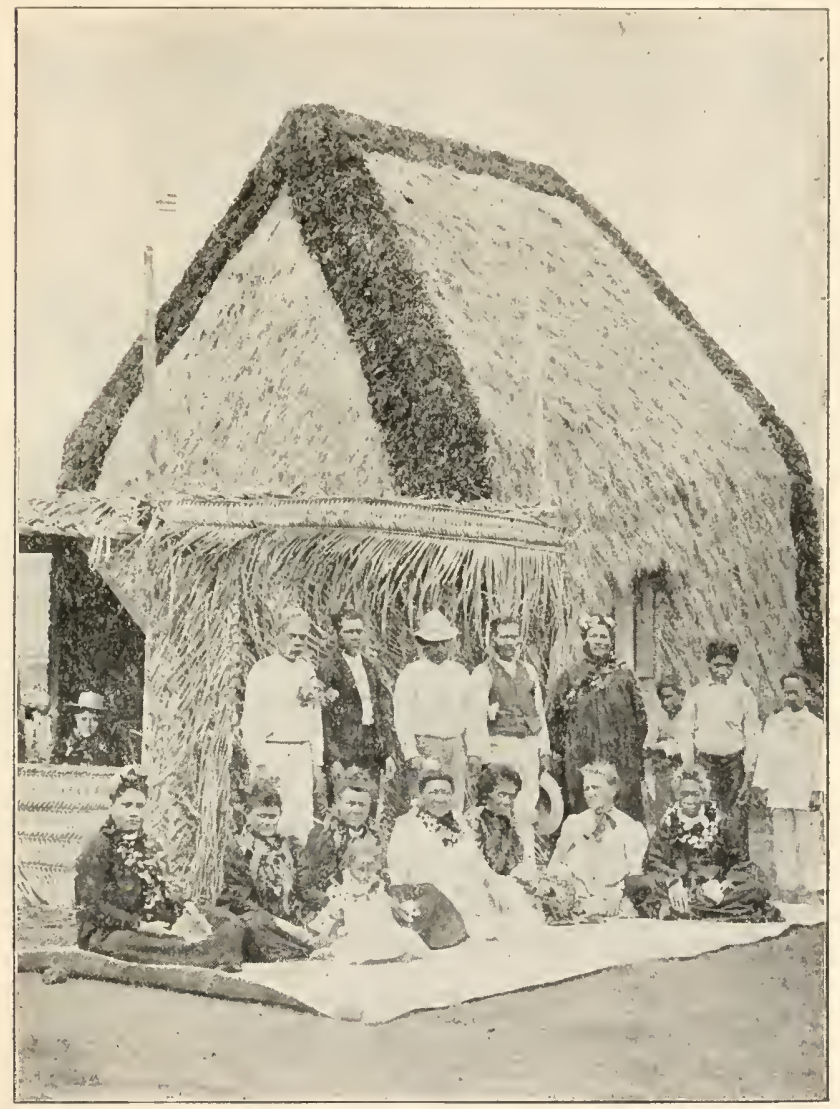

Fig. 9.-Natives and native house.

at the Palace Hotel, San Francisco, Jan. 20. 1891. His sister, Liliuokalani, succeeded to the throne. By a bloodless revolution she was deposed, and the kingdom became a republic Jan. 19, 1893. After a number of futile previous attempts annexation was effected by an 
act of Congress, July 14, 1900. 'The present administration has already made many radical changes in the government of the islands which can not fail in bringing about a more prosperous future.

\section{CLIMATE.}

'The Hawaiian Tslands enjoy an equable and salubrions climate. It is the land of sunshine and breezes. The northeast trade winds fan the islands 225 to 301 days out of the year, and their cooling and invigorating effects are enhanced by the daily land breezes. Anyone who visits Honolulu for the first time and walks or rides along its well-pared and clean streets any time of the year from $\mathrm{S}$ a. $\mathrm{m}$. to $5 \mathrm{p}$. m. may feel the effects of heat and be thrown into a perspiration, when suddenly a land breeze descends from the mountains, cool and refreshing, making the visitor forget that he is in a subtropical region. It is only when the atmosphere sleeps during midday that the stranger feels at all uncomfortable and seeks relief in the shade. The arerage temperature throughout the year is from 69 to is F., extremes, 50 to $90 \mathrm{~F}$.

\section{MATITE POPULATION.}

The Hawaiians are Polynesians, resembling in habits and appearance the South Sea Islanders, who by migration eastward from the Malay peninsula progressed from island to island, undergoing certain changes under climatic and other influences, but retaining to a great extent their originality. In intelligence they are far superior to the negro race, to which they have absolutely no resemblance (Fig. 9). Their; greatest fault is inborn indolence. The average native makes no unnecessary effort, mental or physical. They are as indifferent as children. They abhor agricultural pursuits and prefer to live on waterfronts, where they can secure their fish supply without much effort and amuse themselves with their national sports, swimming 
and canoe or surf riding. 'They do not take kindly to the professions, and will only work under the pressure of necessity. Civilization has rather increased than diminished their repugnanee to labor.

The natives are generous to a fault, honest, easy going. with a happy disposition, but have an inordinate fondness for flattery. They are very fond of flowers and music, but have little, if any, sense of art. The leis (flower wreath) is found on all festival occasions, and is especially comspicuous at the luau feasts (Fig. 10).

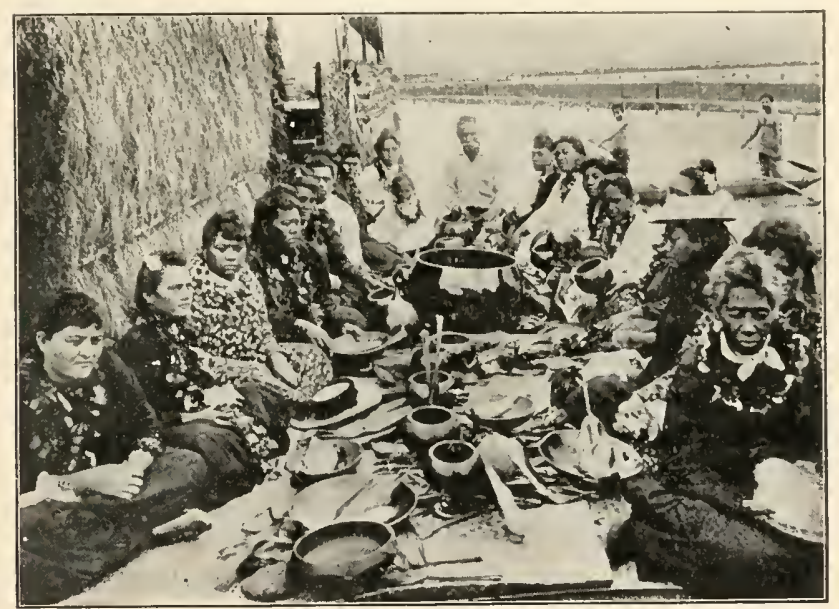

Fig. 10.-Luau, National Hawaiian Feast.

The mortality among the natives since the whites came to the islands has been frightful. When Captain Cook discovered the islands all of them were densely populated, not less than 200,000. In 1836 their number was reduced to $108,5 \% 9$, and at present it does not exceed 39,000. In 1848 one-fourth of the population was earried off by an epidemic of measles; shortly after another 3,000 died of smallpox. The rapid decrease in the native population and their unwillingness to work ereates a field for foreign laborers. In 1898 there 
were in the islands 30,000 Japanese, 24,000 Chinese and 16.000 Portuguese, and since that time the number of foreign laborers must have certainly rather increased than otherwise, as there has been a considerable influx from Porto Rico since the Spanish-American war.

The effects of cirilization on the natives has been harmful as well as beneficial. The first missionaries came to Honolulu in 1820 , when it was a village of huts. with 3,000 inhabitants. For a long time they labored in vain, but in 1837 a strong religious movement swept over the islands, and in a rery few rears paganism had entirely disappeared, at least on the surface. Religion. howerer, did not change the habits of the people to any extent, for

"Nothing is stronger than custom."-Orid.

The missionaries have brought these people the inestimable blessings of religion and education, but

"No sooner is a temple built to God, but the Deril builds a chapel near by."-Herbert.

Education in Hawaii is now compulsory, and within the reach of every child. There is no need for any young man or woman to leare the islands for a good general education, as Honolulu has most excellent schools, including a college and high school. Churches are numerous, both Catholic and Protestant. The churches are better attended than in the states, and the people pay closer attention to the worship than our own. They are emotional and casily influenced for right and wrong. On the whole. the moral status of the Hawaiian would compare well with that of any of our communities. On the other hand, the whites brought to the islands the derastating infectious diseases which have already destroyed nine-tenths of the population, and which threaten complete extinction. The rum shops and gambling are likewise the fruit of the white man's invasion. Syphilis was unknown until the sailor and the adventurer disgraced the soil of Hawaii. It must 
not be forgotten that the mind of the aborigines is more susceptible to the reception of vice than virtue, and the Hawaiians are no exception to this rule, so that many of their original natural virtues are on the wane. On the whole, the natives have paid dearly for what they received from the white man, as the very soil which belonged to them has largely passed out of their hands, and is now owned by foreigners.

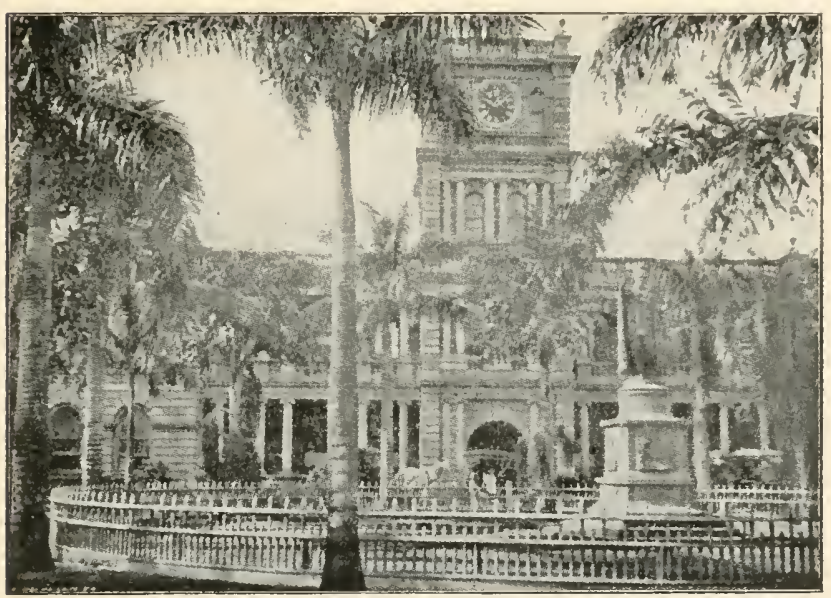

Fig. 11.-The government house, IIonolulu.

\section{PREFAILING DISEASES.}

Since the government of the islands has fallen into the hands of the white population every possible effort has been made to protect the natives against the spread of infectious diseases. The board of health has been watchiful and active in its efforts to improve the sanitary condition of the islands. more especially that of the capital city, Honolulu. Like all primitive peoples, the Hawaiians have absolutely no appreciation of the importance of hygiene and sanitation, and consequently the surveillance of sanitary matters requires constant watchfulness on the part of the board of health. 
The efficiency of the Hawaiian Board of Health will compare well with any of our state boards. It is made up of energetic men, who do their duty fearlessly and withont regard to consequences. The present board, recently appointed and organized, is made up of Dr. C. B. Cooper, president: Dr. IT. H. Mays, S. K. Kane, Esq.; M. P. Robinson, Esq.; F. C. Smith, Esq.; E. C. Winston. Esq., and Lorrin Andrews, Esq.

The last report, for the six months ending June 30 , 1903. contains much valuable material concerning the present prevailing diseases. It is a source of gratification to know from this publication that the reports of the government physicians from nearly every district are unanimous in stating that pulmonary tuberenlosis, that has gained such a firm hold on the natives. is not increasing. The report shows that during that time occurred 13 deaths from bubonic plague, from typhoid fever, 11; diarrhea and dysentery, 32; pulmonary tuberculosis, 64 ; beri beri, 6 ; pneumonia, 39 . The great mortality from tuberculosis shows to what extent the disease is still prevailing. Honolulu, being one of the stations on the ocean highway to the Orient, is constantly menaced with the plague; and, notwithstanding the great vigilance of the quarantine physician, isolated cases will occur from time to time. The stringent measures resorted to by the board of health the moment a case is discovered have so far protected the islands against an epidemic of this much-dreaded disease. The most severe outbreak of the plague occurred in 1890. The disease was imported from Hongkong; and broke ont among the Chinese and Japanese with great virulence. and soon attacked 80 , of which number only 14 recovered. A group of suspects of 500 to $r 00$ was quarantined, and in this way the further spread of the disease was checker. After all danger from infection had been passed the barracks were burned. During the entire epiclemic only 3 whites were attacked. and one of them died. The same ean be said of cholera. 
In 1895 cholera, also imported from the Oricut, broke out, but, thanks to a stringent quarintine of the so or 90 calses, 00 per cent. being natives, the disease was promptly stamped out, never extending beyond the

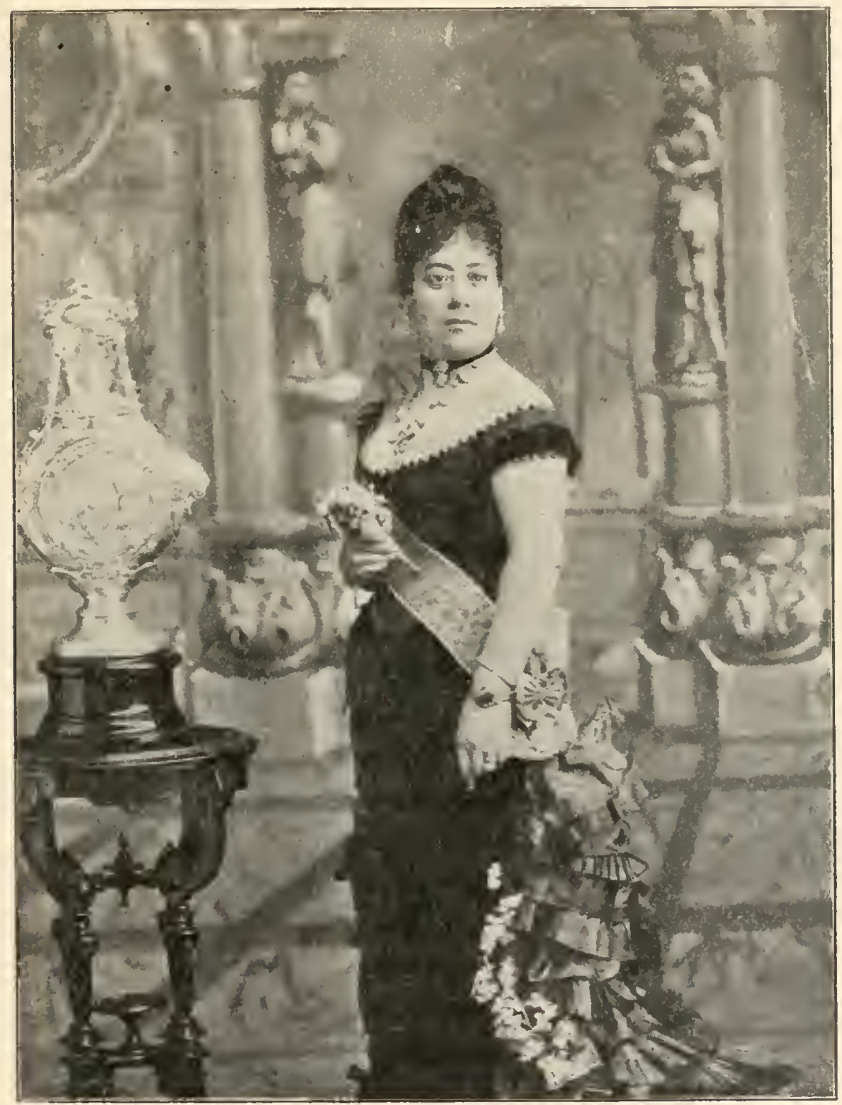

Fig. 12.-Queen Emma, consort of King Kamehameha III.

limits of Honolulu. In 1880 a serere epidemic of smallpox broke out and proved rery virulent in the natives, as more than 10 per cent. of those attacked died.

Compulsory raccination, as now enforced by the board 
of health, will prevent all possibility of a similar occurrence in the future. Scarlet fever has never been epidemie, and diphtheria has always been observed. and that very seldom in isolated cases. Syphilis is not so common as formerly, but the hereditary effeets are widespread and severe, and present and future generations will be made painfully aware of the truth of

"Posterity pays for the sins of their fathers."Quintus Curtius Rufus.

Measles has always been the great curse of the primitive races, and it has claimed thousands of the Hawaiian population. The fearful mortality attending this disease is usually attributed to the recklessness of the patients, as they will not keep their bed, but will persist in bathing to find relief from the fever heat. I believe, however, that such imprudence on the part of the whites would not result so disastrously and that the frightful death rate is more attributable to the slight resistance to the disease on the part of the natives. There onght to be very little, if any, typhoid ferer in Honolulu under the present perfect system of water supply and sewerage. The disease occasionally affects small communities where the sanitary conditions are not so completely under the supervision of the government physicians stationed in the 23 different distriets. Maui is the island that records the largest number of cases of malaria, 121 cases of dengue and malaria in six months, as stated in the last health report, while Kauai and Molokai report none, and only 3 cases are credited to Oahu and 3 cases of typho-malaria and one case of typhoid. The islands continue to supply the leper settlement with new inhabitants to take the place of the dead. According to the report referred to above, the number of lepers at the settlement at present is 888 . In six months the population of lepers was increased by 62 ; at this rate the annual addition to the number of lepcrs would be 124. The report also refers to a large number of suspeets that re- 
main under observation, and from which a large number will be recruited for the settlement as soon as an absolute diagnosis can be made.

Dr. W. J. Goodhue, a recent graduate of Rush Meclical College, has taken up the eause of the MIolokai lepers, and is the present resident medical superintendent. He has already introduced many reforms, and is earnestly seeking a remedy that will eure his patients. He continues the Goto treatment. but has no faith in it. At the suggestion of the board of health

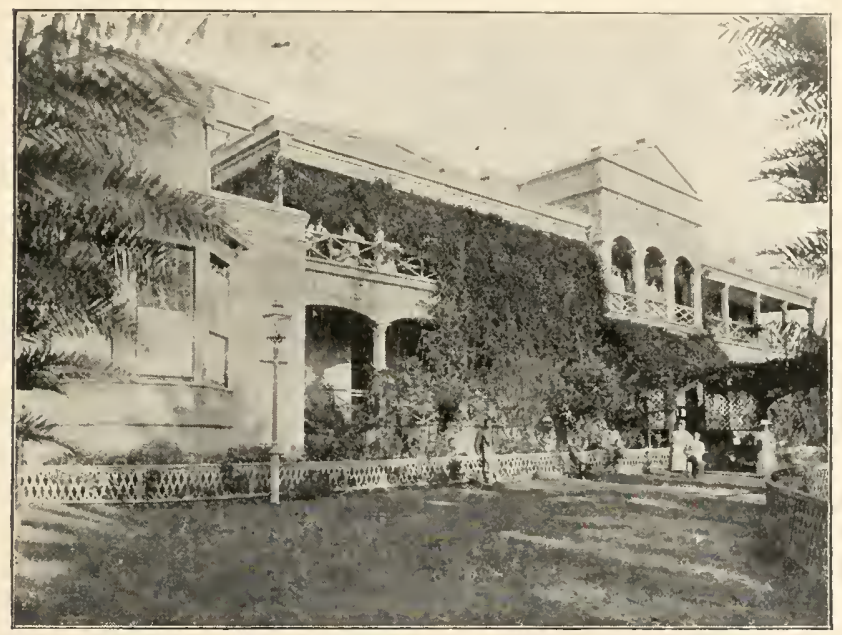

Fig. 13.-Queen's Hospital. Honolulu, established by King Kamehameha III and Queen Emma in 1860.

he is also experimenting with the "Violet Ray." At present he is encouraged by the results of sodium cacodylate. In his report he says: "In sodium cacodylate, an arsenical derivative of relatively slight toxicity containing over 50 per cent. of arsenic, I believe I have found a remedy of great promise in the treatment of leprosy. My attention was first attracted to the remedy by clinical reports of the success attained with it in the treatment of psoriasis, and in diseases in which the wasting and disassimilation are marked features, al- 
though I can not find any account of its ever liaving been employed in leprosy. It is administered hypoderinically, per os, or by rectal enema, and it appears to be entirely free from any appreciable irritative effects on the intestinal or rectal mucosa. I have a limited number of patients on this treatment who, so far, after being on the treatment for from two to three months, show very decided improvement, and I am only awaiting a large supply of the drug before materially increasing the number of patients, when I hope to submit a detailed and farorable account to the board of healtls of the results obtained."

Before disposing of the subject of leprosy and in reference to a former communication on the same, I will add that during my short visit at Honolulu en route I met a number of the most influential physicians, and they were all unanimously opposed to making the whole Molokai Island a leper home. They base their op-

position on business principles. They, as well as the business men of the islands, fear that if this were done the outside world would be prejudiced against the islands, and in consequence the value of property would be depreciated and business injured. There is considerable weight to this argument for the present, but as in the course of time, when it becomes generally known that the colonization of the lepers would be limited to the Molokai Island, snch objection would no longer apply. Still, this is a matter, as I have stated before, for the territorial and general government to consider and decide.

THE MEDICAL PROFESSION.

The medical profession of the island territory is one of the most desirable things that we have inherited by the annexation, a worthy addition to the large body of practitioners of the United States. It is made up largely of young, energetic men who came here well prepared for their lifework. The door of entrance to 
the practice of medicine is well guarded. Every candidate must pass a satisfactory examination before a hoard of examiners appointed by the governor. This board consists of four members, who, to judge from the character of the men who have been licensed, make no farce of the eximmation, as is only too often done in the states. The question of school is not considered, all must pass the same critical test, and if found qualified they can practice any system they please. There are now about 100 licensed physicians in the islands, abont 60 in Hololulu, and the rest scattered in the 23 districts.

Every district has what is called a government physician, who looks after the poor and sanitary matters, and is paid on an average of $\$ 1,000$ a year for his services. These doctors make a semi-annual report of their work to the board of health. Through these channels the board of health reaches the most distant parts of the islands, and thus insures prompt and efficient sanitation. Among the older practitioners in Honolulu belong Drs. MeGrew and MeKibbin and Dr. W. E. 'Taylor, a retired naval surgeon. Dr. C. B. Cooper is president of the territorial State Board of Health. Dr. F. R. Day, a graduate of Rush Medical College, Dr. C. B. Wood, ex-interne at Cook County Hospital, and Dr. Walter Hoffmann, a graduate of Germany, are the leading practitioners. The sick of the yellow races are cared for by 12 Japanese and 2 Chinese physicians. For the benefit of recent graduates I would say that Hawaii has all the physicians it can well support at present; it is no Paradise or Eldorado for a new beginner. The field is well occupied, as most of the men would be hard to discount, and the present depressed condition of the sugar interests is felt throughout the islands. There are only three or four men in Honolulu who have been there for years and who are very popular, that can put down their annual income in five figures. Some of the physicians with a smaller income 
add to it by conducting at the same time some business enterprise.

\section{QUEEX'S HOSPITAL.}

Queen's Hospital (Fig. 13) is the only hospital in Homolutu. It was erected and endomed by the late Queen Emma (Fig. 12), who took a deep interest in charity work. It is a handsome structure, located in the center of a park ornamented with flowers and tropical trees and shrubs. The palm avenue leading from the street to the entrance of the hospital is one of the finest I have ever seen. The hospital is managed by a board of trustees, composed of 40 members, and represents the most influential men of the city. The hospital has a capacity for 90 patients, and the new wing, which is nearing completion. will accommodate an additional 50. Four physicians, appointed by the board of trustees, constitute the staff. Formerly these physicians were salaried, but, I presume in consequence of the additional expenditure incident to the building of the new wing. and the depression in the value of the real estate in which the endowment largely consists, the salaries have been withdrawn. The equipments of the hospital are adequate, and the new operating room will fill a long-felt want. The nursing is in the hands of $S$ trained nurses, who receive a monthly salary of from $\$ 10$ to $\$ 50$. Experiments have been made to train native young women, but they failed, so that the hospital is put to the large expense of hiring trained nurses. The indigent native sick are amply provided for, and others pay according to their means.

MEDICAL SOCIETT OF TIIE HAWAIIAN TERRITORY.

The first attempt to organize the medical profession Hawai was made through the instigation of Dr. H. Wr. Howard, in 1893, when the physicians of Honolulu met from time to time in each other's houses, thus combining social with professional interests. Under the above title a permanent organization has been effected, 
with monthly meetings at which physicians from the different islands attend, so far as transportation facilities will permit. It is a source of regret that the transactions so far have not been published, and, in view of the importance of the subjects that are discussed from time to time, more particularly everything pertaining to tropical discases and island sanitation, the reports of many of these meetings would make interesting and profitable reading for the medical world.

Pago Pago, SAMOA, July 21. 



\section{OUR POSSESSION IN SAMOA FROM A MEDI- ('Al. STINDPOIN'T.}

We landed at Pago Pago on 'Thursday, July 21, at $6: 30$ a. $m$. The natives were on hand to weleome us, and many a greeting was expressed in the euphonious word "talofa" (love to you). 'The moment the ship was anchored in the harbor a fleet of eanoes surrounded it and their brown inmates in native attire-men whose only garment was a breecheloth. women in the loose, comfortable Mother Hubbard ealico dress, children with no clothing incumbrances of any lind, all of them with a copions growth of jet black long curly hair freely exposed to sunlight and breeze, with upturned faces and large. gentle, imploring coal black eyes-were soliciting patronage for the products of their charming island. Gaudily painted tapa cloth made of the bark of a tree, coral beads, baskets of various designs and sizes, shells and tropieal fruits were the principal articles offered for sale. The competition between the dusky rendors was not a spirited one; it made little difference who reaped the greatest profits, as in a short time the gain of the morning's sales according to the customs of the island, would soon he shared equally by all. ()ur time in the harbor being limited to a few hours. I was very anxions to improve every minute in studying the resourees of the island, its people and their diseases. By previous appointment I was met on board by Dr. H. E. Odell, P. A. Surgeon U. S. Nary, the medieal officer of the training ship Adams, now in the harbor (Fig. 14). To this officer I am greatly indebted for many eharming courtesies and most valuable information. He took me ashore at once in the govermment launch and on landing introduced me to Chief Pan Pan of the village Aua, who happened to 
be present, a man highly esteemed by the natives and whites for his excellent character and good judgment. His distinctive dress consisted of a long white coat, with shoulder-straps of the same color with a narrow border of blue. His whole bearing impressed one with the dignity of his office and firmness of his character. From the time we entered the harbor until we reached the shore I had looked in vain for the American flag. I saw the bare. tall pole in front of the custom-house and was wondering what had happened in international politics since I left San Francisco, that it should hare been stripped of our colors. The information came without asking any questions. A few minutes after landing a motley crowd gathered around that pole, and presently I had the pleasure of witnessing the hoisting of the American flag (Fig. 15). This is a ceremony that takes place every day at 8 o'clock in the morning. The moment the Stars and Stripes reached the lofty destination, fluttering in the fresh morning breeze, the native band played our national airs, "МY Country, 'Tis of Thee" and "Star Spangled Banner," and the mountains re-echoed the strains of the stirring music so dear to the heart of every American. The ceremony was an impressive one. The native guard, composed of 72 picked men. magnificent specimens of physical development, wearing a red turban, white sweater and blue trousers. standing at attention with arms at rest. The crowd of people, including many children, stood motionless, not a word being spoken until the last strains of the music had died away in the soft, balmy air of the tropics, when the guard shouldered their arms and marched away to their respective posts of duty in a truly soldierly manner and the crowd dispersed as quietly and silently as it had gathered. This beautiful ccremony reminded me that I was on American soil in the midst of the rast trackless Pacific Ocean, nearly 5,000 miles away from the western limits of the United States. 
SKETCII OF THE IIISTOII OF THE ISLANDS OF SAMOA.

Not all the people of the United States are aware of the fact that the beantiful island of Tutuila of the Samoan archipelago is one of our ocean possessions, and very few know how it was acquired. In making inquiries among officers and passengers of the Sierra regarding this subject I became satisfied how little there is known about it. The history of Samoa, especially

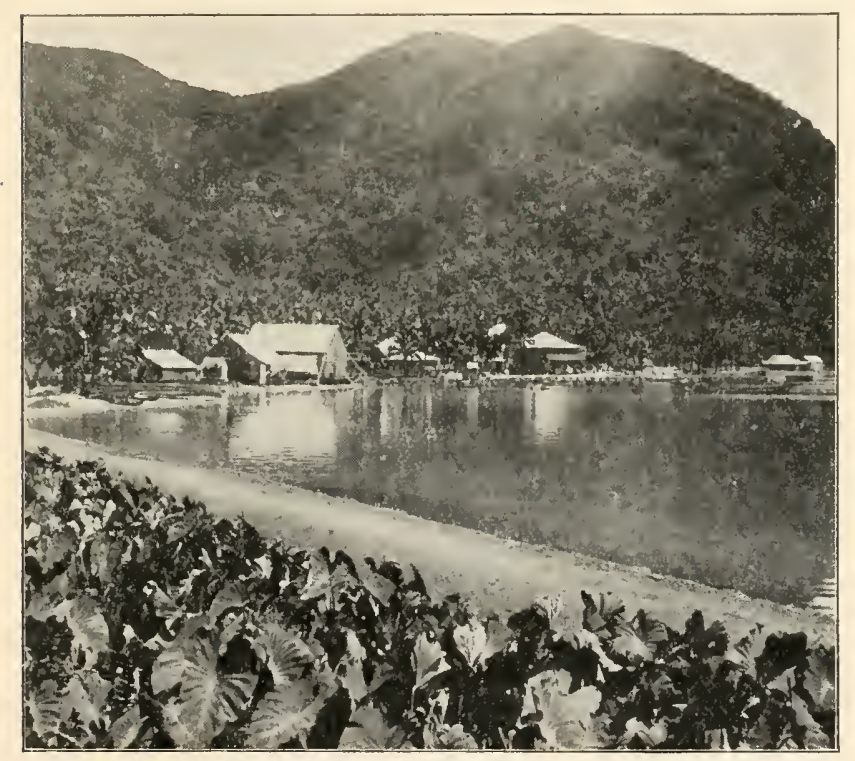

Fig. 14.-Tutuila, Samoa, U. S. Naval Station.

the recent part of it, leading up to the time Tutuila was ceded to the United States, is a very interesting one, and does not reflect much credit on some of the foreign powers, especially Germany. The extent to which Germany meddled with Samoan affairs and the fact that she now owns the two largest islands, Saraii and Upolu, are matters difficult to explain. The recent history of Samoa is a tangle difficult to unravel without losing the thread, owing to the rapidity of succession of 
events cansed by contending internal political factions. complieated by outside interference. Space will permit me only to gire a few outlines. The Samoan arehipelago. composed of not less than fourteen voleanic islands with numerous adjacent islets, lies nearly east and west between the parallels $13^{\circ} 31^{\prime} \mathrm{S}$. and $14^{\circ} 31^{\prime}$ S.. and longitude $1 \div 2^{\circ} 45^{\prime} \mathrm{W}$. and $168^{\circ} 9^{\prime} \mathrm{W}$. The last rolcanic eruption occurred in Savaii in 1866. The islands were first seen by Roggereen, but their discorery is generally accredited to Bougainville, who came there in 1768 and stocked them with domestic animals. He called them Narigator Islands. It is supposed that the islands became populated by Polynesians migrating eastward from Sumatra, ria the Philippines and Hawaii, by a party of less than fifty, in seren canoes. Two hundred years later the Tongans inraded the islands and, with the aid of Fijians, drove the Samoans into the mountain retreats. The hardships endured by ennstant persecution served to strengthen the Samoan forces. who finally gained the upper hand and cleared the two largest islands, and later all of them, of the invarders. Camnibalism was introdnced by the Tongans. but was abandoned before the arrival of the explorers. The missionaries came in 1833, and one of the first fruits of their indefatigable labor was the conversion of Malietoa, one of the most powerful chiefs, who was christened Davita. This event gave rise to a religious ware which soon reached the different islands.

Frequent strifes between the different islands and tribes induced the natives to look to the United States as early as $18 \% 2$ to establish order out of chaos by requesting our goremment to send Colonel Steinherger of New Tork as adviser. Two years later President Grant granted the request. The colonel soon improved the arministrative affairs of the islands and had the full confidence of the natives. His influence excited the enry of the British and in less than a year he was deported by a Britsh warship, no protest being made 
hy our consul, and the umwaranted action lad the full sanction of King Malietoa Iaupepa. Insurection followed and the king was deposed. From now on the political events followed in rapid succession by the acaressive interference on the part of Germany. Talaroa was elected king, but died after a short tumulturows reign, and Lampepa again sneceeded to the throne only to be again deposed in 1885, when he was exiled by the German fleet. Insmrection nnder the leadership of Malictoa Mataata again msettled political affairs. It one time the German, English and American warships

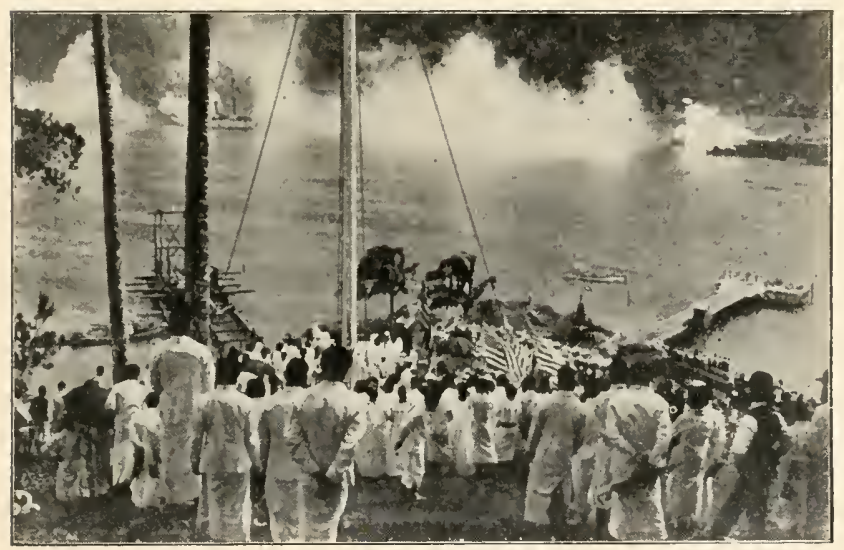

Fig. 15.- lag-raising ceremonies.

in the harbor of Apia were ready to clear the deeks and begin war between Germany on one side against the other two powers, when the great storm swept them (nut of existence with the exception of the English gunboat Calliope. Aetive interference on the part of the United States resulted in the Berlin conference, which deelared in favor of Laupepa against the protest of the natives. With the assistance of a German and British warship Laupepa defeated the forces of Mataafa near Ipia in 1893, who shortly afterward surrendered to the British and was exiled to the island of Jalnit with 
twenty of his chiefs, where he remains at the present time. On the return to power Laupepa abdicated in favor of Mataafa, but European diplomacy again interfered and he remained on the throne. After Laupepas death in 1888 came the contest between the exiled Mataafa. who had the German influence, and Tana, the son of the dead king. After a number of fierce contests the matter was referred to Chief Justice Chambers. who decided in favor of the heir to the throne. Finally Admiral Kantz of the battleship Philadelphia interfered and insisted that both contesting parties should lay their claims aside. England now withdrew from the contest. leaving the Germans and Americans in the field to dispose of the islands. A satisfactory agreement was reached by which, on Nor. 8, 1899, the two largest jslands, Saraii and Upolu, were ceded to Germany, and Tutuila, with its magnificent harbor, became the property of the United States.

\section{OER SAITOAT ISUANJ.}

Out of the internal dissensions and whirlpool of foreign interrention arose for us, phoenix-like, Tutuila. the most beautiful, and. from a strategic standpoint, the most important of the Samoan Tslands. Pago Pago harbor is land-locked, with an average of thirty fathoms in depth and sufficiently large to give protection to a flect of from six to eight of the largest men-of-war. with a strip of land belonging to it amply large for gorermment buildings, barracks and coal sheds. The harbor is hemmer in by mountains on all sides, from 1,500 to 2.500 feet high, except the narrow gateway communjeating with the ocean. These mountains form a safeguard against any hurricane. no matter how serere it might be. The entrance is so narrow that a few mines and a battery on the high hills on each side could keep the largest naval force at bay. The island is 19 miles long and 230 in circumference. A mumber of islets helonging to it and inchuded in the treaty streteh along 
the same cast and west line, the farthest ahout sixty miles away. The main and adjacent islands are forestclad, without a bare spot in the dark green carpet, $\mathrm{c} x$ tending from the shores to the highest mountain peaks. The primitive forests have never been disturbed, as the natives liave had no use for timber either for themselves or barter. The forests are dense, almost impenetrable. and some of the trees, especially at the very summit of the mountains, are of prodigious size and would vield hardwood timber of great commercial value. The rim of lowland at the base of the mountains. when it exists.

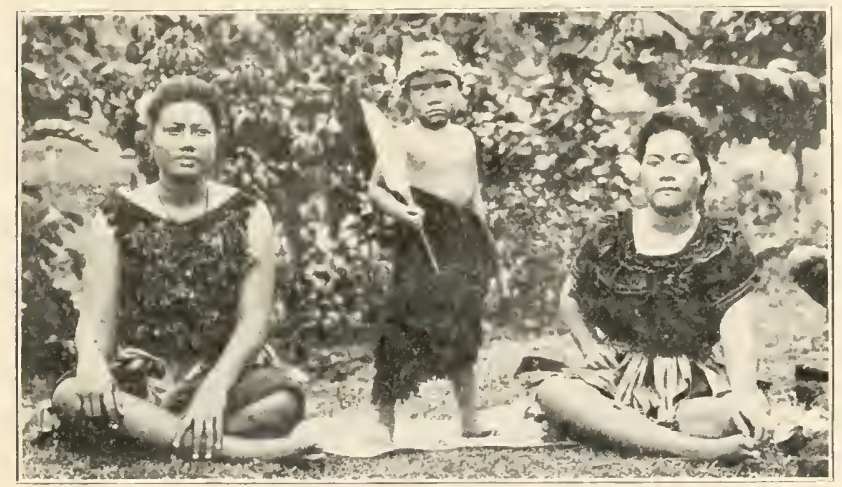

Fig. 16.- Samoa women and child.

and the valleys near the shore line, are covered with groves of cocoa palms, and wherever a sufficient number of these trees are found a hut or small hamlet of huts may confidently be looked for. The voleanic formation of the entire island is covered with a thick layer of the most fertile black soil, as shown by the size of the trees, the luxuriance of the shrubs and plants and the abundance of nutritious grass. The soil and climate are admirably adapted for the growing of coffee, cacao, taro and all kinds of tropical fruits.

\section{CLIMATE.}

The climate of Tutuila is influenced by the mbroken, dense, virgin forest. We see here a very instmetive ex- 
ample of what such forests are capable of accomplishing in the way of securing an adequate rainfall. Drought is mknown. The rainy season in the Samoan Islands is supposed to be during the first three months of the year, but in Tutuila it rains more or less throughout the year, rendering the atmosphere damp. The rainfall last year, according to Dr. Odell, reached nearly 200 inches. Every ravine leading from the mountain heights to the sea has its rivulets or small rivers, which drain off the excessive moisture of the saturated soil, furnishing the inhabitants all orer the island with a fanltless water supply. The climate is uniform, the tropical heat modified by sea and land breezes. The temperature seldom rises above 85 degrees $F$. and is rarely less than $i 2$ degrees $\mathrm{F}$., although on rare occasions the thermometer has registered as low as 60 degrees F. (Odell). The nights are generally delightfully cool. The climate is, on the whole, very similar to that of Hawaii.

\section{THE PEOPLE.}

"They eat, they drink, and in communion sweet "fuaff jummortality and joy."-Milton.

The Samoans are a noble race, simple, honest. affectionate. peaceable and hospitable. The men are splendid specimens of physical development. above arerage size, and with a courteous and noble bearing. I observed several women who were close to the six-foot mark and as erect as the poles of a bamboo thicket. I noticed that many of the women and some of the men had dark brown hair. which. I was informed, was the result of a process of bleaching with lime. done either with the intention of ridding it of its live inhabitants or for cosmetic reasons. The women are rather fairlooking when young, but lose their attraction before they reach the age of $30 \mathrm{by}$ premature old age and obesity. Tattooing among men remains as a national custom. It is done as a eeremony as soon as the boys 
attain virility, and the field of operation corroponds with that part of the body covered by their only garment-the breccheloth-so that in the event anything goes wrong with this, the simplest and oldest dress, they should not appear entirely nakerl. The operation is performed by experts. whose implements consist of a little fine-toothed comb made of the tusk of a wild boar, which is fastened to a small stick in the form of a minnte rake. The teeth are dipped into the staining material, and with blows of a little stick on the blunt end of the comb they are made to penetrate deep enough to drive the stain into the deeper layers of the skin. The operation is attended by great pain, and lasts, accolding to the artistic designs employed, from five hours upward. The lines of tattooing are exceclingly fine and the patterns are often quite artistic, as I had an abundance of opportunity to observe. There is very little erime among the Samoans. For four years there has been only one murder in Tutuila with its 6,000 inhabitants. The whites never lock their doors. What we look on as petty thefts, such as taking away without permission a loaf of bread, a fish or any kind of fruit, is not regarder in the light of crime by the childlike Samoan. The next day the neighbor so treated will even up the account in a similar manner. So far as the food supply is concerned, the Samoans constitute one great family, giving and taking as occasion may demand, and the stranger is always welcome to more than his share. Family life is ideal. The father rules supreme; old age is respected; the ties of relationship and friendship are strong. No operation can be performed on a Samoan without a previous family council. If the father is the patient the sons decide the matter. if any other nember of the family is concerned the father alone has the power to object to or sanction the operation. The bedside of the sick is never deserted by the immedi. ate members of the family, and anxious relatives and friends are never far away. 
The educational adrantages of Tutuila are as yet in their infancy, a defect which should soon be remedied, as the children are rery fond of school work. The Catholic Sister's are here, and, as on so many other frontier lines, they are the pioneers in placing within reach of the ignorant children the means of obtaining an education. They have opened a school in a village near Pago Pago, which is already filled to overflowing with the little dusky scholars. All of the inhabitants are nominally Christians, but religion has failed to wipe out many traces of paganism. There are very few legal marriages consummated. The native custom still prevails. Man and wife consent to live together, and continue to do so as long as the matrimonial shy is clear, but should anything occur contrary to the expectations of the husband the tie is severed by returning the wife to her parents or relatives. The children are always provided for. Unless other arrangements are made which are satisfactory to both parties, the sons remain with their father and the daughters accompany their mother (Fig. 16).

The kahuna, or native medicine man, remains, and has not lost his influence among his people. They continne their mysterious ceremonies and the use of herbs and roots in battling with the diseases they are called on to treat. The remarks of Father Damien concerning the native doctors of Hawaii apply to the kahunas of Samoa: "We have to fight their doctors, who are generally nothing but sorcerers. In cases of sickness idolatrous sacrifices are still in use. All diseases are attributed to mysterious causes. It is very hard to disabuse these poor people of such superstitious notions." Superstition remains unshaken by the teachings of the gospel, a strong proof of the truth that

"Nothing has more power over the multitude than superstition; in other respects powerless, ferocious, fickle. when it is once. captivated by superstitious notions, it obeys its priests better than its leaclers."-Quintus Curtius Rufus. 
I'RLSENT FORAL OF GOVERTMENT.

Our govermment has very wisely interfered as little as possible with native rule. The harbor, with a strip of land belonging to it, is exclusively under the control of the officer in command oi the naval force

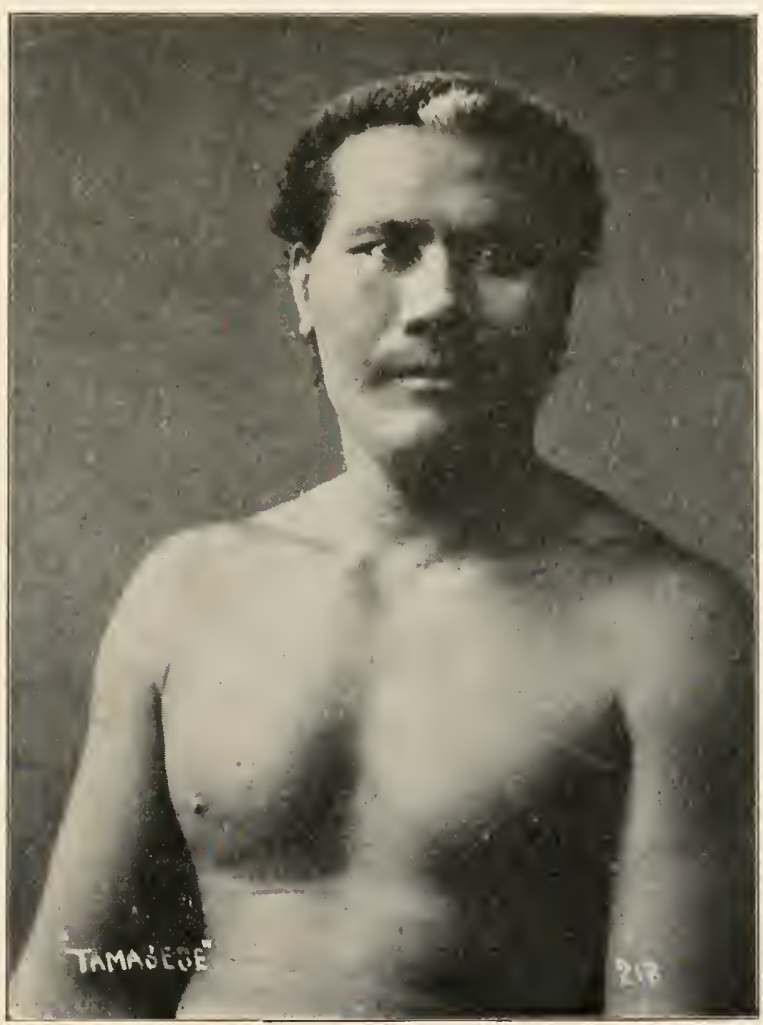

Fig. 17.- Tamasese. Fine specimen of Samoan.

stationed there. He is at the same time the commandant of the island, to whom the chiefs can appeal in all matters in which they find it necessary to obtain advice, or when they fail to adjust local difficulties in their respective communities. The naval surgeons stationed at Pago Pago have in charge the sanitation of 
the island and the care of the sick poor natives. 'They have already succeeded in securing for Pago Pago, a village of 1,500 inhabitants, a pure water supply and many other sanitary improvements. The greatest fault with the Samoans is their inborn laziness. They will not work. The govermment has now under way many improvements, and, althongh the wages for this part of the world are large, $\$ 1$ a day, it had to import laborers from other islands to do the work. Civilization has rather increased than diminished this inherent repugnance to labor.

\section{KAYA DRINKING.}

Kava is the national drink of the Samoans. They have not, like onr Indians, an ungovernable desire for alcoholic stimulants. Kava is the fleshy root of Piper methysticum, a succulent plant about four feet in height. with large, long petioled leaves. In propagating the plant all that is necessary is to break off one of the leares at its point of insertion, including the bulbous base of the petiole. and stick it into the moist. rich, black soil. Kara drinking is a ceremony. Dr. Odell was kind enough to gire me an opportunity to observe this ceremony in all its details and to sample the product. Whenever possible the drink is prepared by a young woman, who alwars regards the task as obligatory, as well as a privilege, if not of distinction. The first young lady that passed Dr. Odell's bachelor quarters was called in, and she went through the entire performance with a grace and elegance that showed she was no novice in that part of her domestic functions. Formerly the root, fresh or dried, was chewed by young women. Now the dried root is crushed on a stone, and the coarse powder is placed into a shallow bowl of hard wood, supported on very short legs, the pride of every Samoan family: it is to them what the samovar is to the Russians. After pouring cold water on the pulverized root it is stirred vigoromsly with both hands for 
about five minntes. When the straining is commenced with a swab of bark fibers, which is continued until all coarse particles are removed from the soapy-looking liquid; the entire time required being about fifteen minutes. The liquid has a peppery, rather pleasant taste. It is served in cups of carved cocoanut shell. 'This: drink suits the place and climate better than any other heverage. In larger quantities it prodnces a form of sight intoxication, in moderate quantities it is a diuretic and slight soporific.

\section{NATIVE IIOUSES.}

'The natives remain true to their original architecture in the construction of their louses. The houses are circular, open, the round dome-like thatched roof resting on poles. The rafters are made of the brear-fruit tree, held together and fastened to the upright poles with an intricate lacework of bark and twigs. The ground is covered with gravel. The bed consists of tapa mats, and the pillows are bamboo sticks, as large as the ar'm of an adult, supported by props at each end, about four inches in height. The cooking is done outside. As there is no furniture in the house the domestic ruties of the female part of the family are certainly of the simplest kind. The tapa cloth is made of the thick. soft bark of a tree; it is pounded into thin sheets, dried and painted in figures most pleasing to its future owner. It is the principal article of barter, and its abundance or scarcity constitutes the wealth or poverty of the family. These open houses and the frugal diet are most conducive to the preservation of the native's health. Indoor air, combined wth the inherent inactivity of the natives, conld not fail in multiplying disease and increasing the death rate.

DISEASES.

Samoa, like all islands of the Sonth Pacific, has lost its full share of population from the effects of the in- 
fections diceases introdnced by the whites, notably measles, smallpox and tuberenlosis. Vaccination is now generally practiced by the naval surgeons, and the matives subject themselves willingly to this prophylactic measme. The spread of infections diseases among the natives is favored by their habits. Their affectionate natmre and the strong ties of friendship bring relatives, friends, communities and different villages in continuous and frequent contact with the aftlicted, and in this manner infection is carried in all directions. and in a remarkably short time by progression from place to place will reach the most remote parts of the island. I imagine that any efforts to eut off free communication betwcen the sick and well would appear as an infliction of eruelty to the natives, and wonld meet with their displeasure, if not persistent opposition. It is this free intercourse among the people that accounts for the rapid spread of measles and other acute infections diseases over the entire island. The natives have absolutely no comprchension of the importance, much less of the necessity, of enforcing sanitary precantions.

Tuberculosis affects most frequently the lungs. as this organ becomes most frequently predisposed by catarrhal affections, which are very common; next in frequency are the bones and joints, and lastly, the lymphatic glands and intestinal canal. Leprosy is unknown in Tutuila. On the other hand, elephantiasis is rery common. Tt is estimated that of the male population over 40 years of age, 50 per cent. are suffering from this disease. It attacks in preference the lower extremitics, but not infrequently the upper become involver, and scrotal elephantiasis is by no means rare (Fig. 1\%). Dr. Odell has operated on a number of cases of scrotal elephantiasis successfully, in which the mass remover weighed twenty and more pounds. The disease is much more common in men than women, undoubtedly because they are more frequently the subject of lesions. which determine infection. The disease is nccasionally 


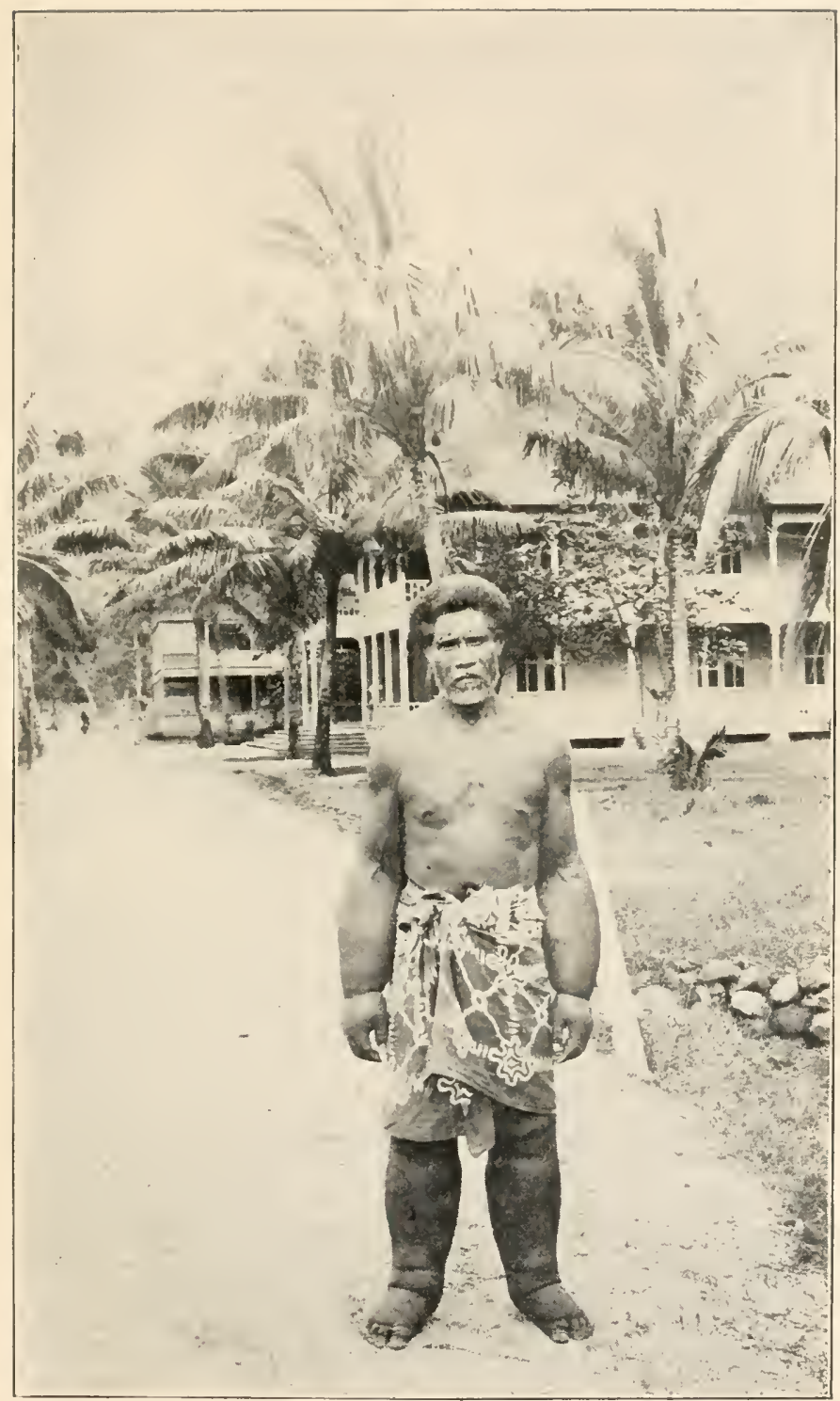

Fig. 1S. - A native of Tutuila affected with elephantiasis affecting all extremities. 

met with in children less than 10 years of age, and not infrequently in young men at the age of 20 . 'There are only about fifty whites in the island, and one of them, a German, has been a resident for thirty-two years. He married a native woman and raised a large family of children. He is now $5 \%$ years old, and contracted the discase twelve years ago. It affected the right leg, pursucel a somewhat acute course, and recently a complicating affection of the knee joint made an amputation of the thigh necessary. He made a good recovery, and will leave the hospital in a short time for his island home. This ease, like so many others, proves that a prolonged residence in a tropical climate renders the whites susceptible to infection. Skin affections are rery prevalent in the island, more especially ulcers of the leg. Tlie lack of clothing and footwear is undoubtedly largely responsible for this, exposing the parts to all sorts of mechanical irritation in walking through the dense bush and along the stony, pebbly shore. These nleers yield promptly to treatment by rest and the local use of antisepties. Another common affection is the socalled tropical abscess, a deep-seated, somewhat subacute phlegmonous inflammation, attended by only slight constitutional disturbances. It is undoubtedly the result of infection through surface lesions which are so common, that is, the entrance into the tissues of some mild form of pus microbe through a surface infection-atrium. These abscesses heal very promptly after incision and drainage. The frequency with which hydrocele is met with is attributed by Dr. Odell to Filaria sanguinis infection, but he has encountered no difficulty in effecting a radical cure by the usual operative treatment. Among the skin affections vaw figures very largely. Dr. Odell showed me a little girl suffering from this disease. The lips and lower segment of the face were covered with very superficial weeping ulcers. He relies on mercury and chalk incorporated in a salve in its treatment, and has never seen it fail in 
effecting a speedy healing of the ulcerated surfaces. Venereal diseases are not nearly as common in Samoa as in Hawaii or Tahiti, as the women are more virtuons, especially in their relations with white men. The humidity of the climate, the cool nights, absence of clothing. inadequate corer during sleep, are responsible for the frequency with which diseases of the respiratory organs prevail. Pneumonia occurs in a somewhat mild form, as the mortality is not great. Epidemics of influenza sweep over the island almost every year, and affect young and old. but the disease is mild. $\mathrm{T} Y$ phoid fever is unknown. Malaria in certain localities is quite common, but always of the mildest type, rielding rearlily to the internal arministration of quinin. Diarrhea among infants and children, caused by improper dict and exposure, is a very common affection throughout the entire rear. The question has often occurred to me whether or not appendicitis is as frequent among the people who live largely on breadfruit, bananas, and cocoanut, that is a laxative regetable diet. as it is with us, who are more imprudent in the matter of diet. That the disease is rare in the islands of the South Pacific I am sure, that it does occur is shown by a case recently operated on at Pago Pago by the preiecessor of Dr. Odell. The patient made an excellent recovery. Dr. Odell has been at his present post since December. but so far has not seen a single case, although his clientele is very large. Dysentery as observed here is not a common disease, and yields readity to treatinent. The island has so far escaped the ravages of scarlatina and diphtheria, the scourges of childhoor in most of the cirilized countries. The sanitary condition of the island appears to have been improvel during the last few years, in consequence of which the popnlation is now increasing. 


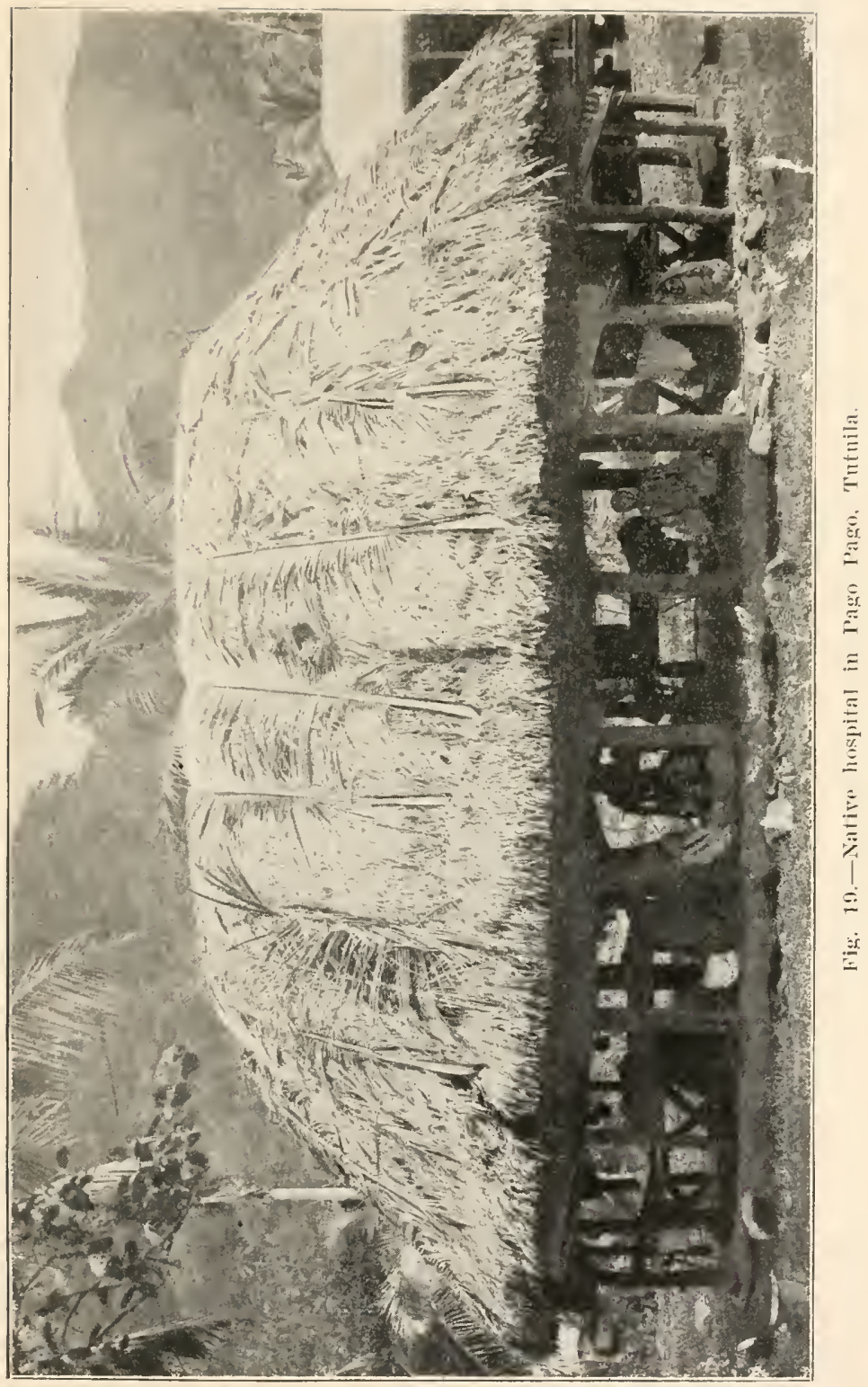



IIOSPITALS.

The plural number of this subheading will undoubtedly astonish the readers. Pago Pago is the only place in the island that affords hospital facilities, and this is a village of not more than 1,500 inlabitants, and om naval force does not exceed 120 men. Nevertheless, it has two distinct hospitals adjoining. One is a small. one-story cottage, with four small rooms, in which all the operating is done and in which the more serions cases and the soldiers are cared for. It would be difficult to crowd into this hospital more than twelve or sixteen cases, and yet it has met, so far, the urgent needs (Fig. 19). The second hospital is a unique one. It is nothing more nor less than a large native house, built by the natives, for which the government paid them $\$ 100$. The cots furnished by the government are the only articles of furniture. The natives can come and go as they please, as they take care of themselves. Men and women live under the same roof. In case of an cmergency about twelve patients could find shelter here. Its greatest merit is the perfect ventilation. At the time of my visit I found here three patients, one woman recently operated on for extranterine pregnancy, a man affected with elephantiasis, and another one the subject of extensive ulcers of the leg. These pationts have no lack of nurses, as $a^{\circ}$ crowd of relatives and friends is always in attendance. Dr. Odell attends to their medical and surgical needs.

The obstetrical work in the island is attended to by neighboring women. The patient, as well as the improvised midwife, have only one thing in view when a new Samoan is on his way into the world, and that is to shorten the ordeal as much as possible by a combination of muscular force on the part of the patient and her attendant. It speaks well for the climate that, notwithstanding even ordinary cleanliness on such occasions is ignored, to say nothing of modern aseptic 
precautions, and a maximum of force is brought into play, sepsis very seldom follows, and the mother resumes her customary, routine household dutics the next day. These strenuons deliveries, as a matter of course, result in extensive lacerations of uterus and perineum.

One death from puerperal sepsis came recently under the care of Dr. Odell. It was a case of retained placenta, in which general sepsis had dereloped before he was called. In spite of prompt extraction of the putrid mass, and thorough disinfection. the patient sucemmed to acute sepsis. Dr. Odell has performed three successful laparotomies during his residence in Pago Pago: 1. Ovarian tumor. 2. Dermoid of ovary. 3. Ruptured extrauterime pregnaney. Patients take anesthetics well, and wounds heal promptly. Myofibroma of the uterus does not appear to be as common in the women of the South Seas as is generally supposed; on the other hand. lipoma in all it farorite localities is very frequently met with in both sexes. It will, in conclusion, interest the readers to know that our island in the Pacific has a newspaper in the native language. published every month at gorernment expense and distributed gratuitiously anong the inhabitants. Through this medium they receive the local news and keep in tomch with the outsirle world.

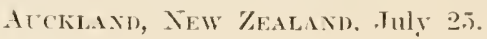




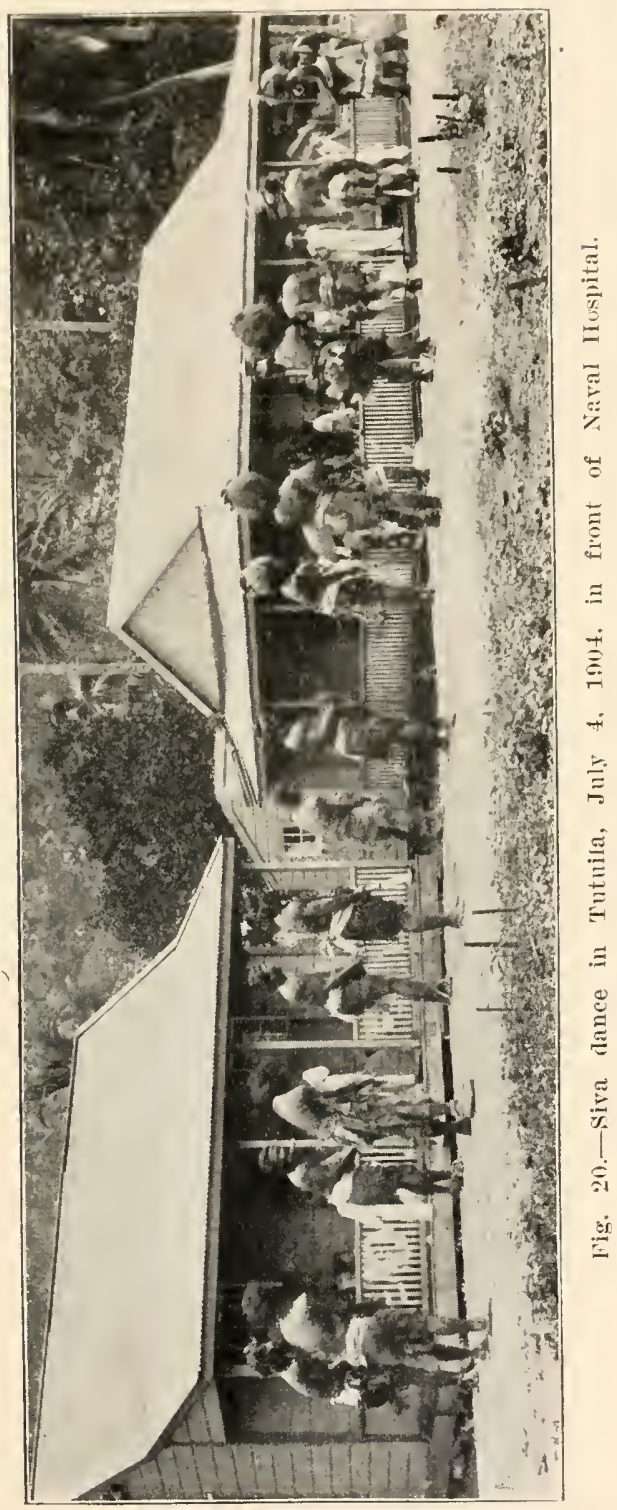





\section{NEII ZEALAND.}

THE OCEAN VOYAGE-CLMATE-NATIES-AUCKLANDAUCKLAND HOSPITAL-MEDICAL PROEESSION.

'The American has become during the last twenty-five years an enthusiastic traveler, and the increasing prosperity in our country will only tend to increase his desire to see the outside world and familiarize himself with the greatest of all subjects-man-his customs and habits in various parts of the globe, as well as the conditions, climatic and otherwise, which influence his physical and mental characteristics. The observing traveler will have become aware that

\footnotetext{
"Men's characters and habits are not influenced so much by the peculiarities of fanily and race as by the physical features of their native land and their mode of life-things by which we are supported and by which we live."-Cicero.
}

The people of the United States spend annually $\$ 160.000,000$ in touring the old world; very few, indeed, direct their steps westward, and we as a nation know very little of New Zealand, the land of geysers, mountains, glacier's, fjords, and the Maoris of the great continent of Australia, its strange animals, trees and flowers, its vast plains, impenetrable forests, and the home of one of the most primitive of all races. The American globe trotter usually selects the Japanese ronte. For a summer trip the Anstralian route is decidedly the best.

TOYAGE FROM SAN FRANCISCO TO NEW ZEALAND.

The southwestern part of the world, New Zealand and Australia, are now readily accessible to the traveler by the establishment of a regular steamer service. The three sister ships of the Oceanic Steamship Company, 
the Sierra, Sonoma and Tentura, modern 6,000-horse power steamers, make the trip regularly every three weeks. The table is excellent and the service faultless. The distance from San Francisco to Auckland is nearly 6,000 miles, and the time to cover it 18 days. The monotony of the voyage is broken by making stops at Honolulu and Pago Pago long enough for the passengers to get a good glimpse of the tropies, their inhabitants, animal life and products of the soil. Between these places is the desert ocean, and the passenger who does not know how to improve his time profitably might be tempted to complain of

"The burden of the desert of the sea."-Isaiah xxi, l.

We never saw a sail or puff of smoke on the whole voyage, except in the harbors. The interested traveler has, however, enough to see and observe. 'The endless, trackless waste of the ocean in itself is something wonderful to contemplate, in its varions moods of peace and rest, anger and storms. The glorious sunsets paint pictures on sky. sea and clouds that delight the eye of the most unappreciative of the wonders of nature. The starlit sky and the silvery moon enlighten the evenings and shorten the long nights in the tropics. One day out from Honolulu the sun crossed our ship, and two days before we reached Auckland the full moon, from its lofty position, smiled directly down on the very tips of its masts. The great crest-covered furrows ploughed by the ship on each side reminded one of the speed with which we move on, and at night hypnotize and delight the sense of sight by their phosphorescent illumination in the form of myriads of diamonds, which come and disappear in the twinkle of the eye. The animals encountered in the South Pacific are few, hence more eagerly looked for. That daring, tireless mariner, the sea-gull, followed the wake of the ship nearly the entire distance. Brown and white, large and small, these graceful flyers circled in the air. with little effort on 
theil palt, emming and going ly simply spreading their wings, their sharp exes tiserl on the turbulent water whipped into a dimimtive storm by the revolving serew, patienty wating for their time to feed on the refuse of kitchen and table, and the moment it appeared in the agitated waters, with nuer'ing aim would dash from their height with the speed of an arrow, grasp and arcedily devour the cherished morsel. The flying fish, single. in pairs, or in schools of many, when the sea is quiet, frightened by the approach of the ship would dash from their briny element into the air and make their short flights in gentle eurves, striking the water at a distance of about thirty yards, rebound and make one or two other flights, finally to disappear with a splash from whence they came. With these things aromo and about you and useful books to read, the longest sea royage is stripped of its monotony. From Honolulu to Samoa the average temperature in the cabins on the port side of the ship was 80 to $82 \mathrm{~F}$. At one time my thermometer registered $100 \mathrm{~F}$. in the sun. The southwest wind was constant. In less than four hours after leaving Samoa a cold breeze set in which forced the passengers to lay aside the white suits and rummage their trunks, for elothing of a more somber color and heary underwear. That evening blankets were in demand, and next day those not used to a colder elimate paced the deck in fur and orercoat. This sudden change in the temperature reminded us that we were approaching a part of the world where the seasons are the reverse of ours.

From now on the sea became rough, which, combined with a heary wind and drizzling rain, soon cleared the decks. At noon, Jnly 26 . we passed several barren islanils, and soon the lngged, hilly, almost treeless roast of New Zealand was sighted, and at 2 o'clock we reached the wharf of Anckland. The harbor of Anckland is one of the finest in the world. All the navies of the world would find here ample room, not only as 
a place of safety, but enough space in which to manenve.

\section{CLIMATE.}

We found New Zealand in the grasp of midwinter. however not with ice or snow, not eren frost. The grass had lost its cmerald green, and the naked trees with decicluous leaves were about the only reminders of the New Zealand winter. Many of the garden flowers, roses and violets, were in full bloom, and the grassy slope: of MIt. Eden were checkered with a little white flower that peeped through the low grass, anxious to inform the visitor that it had survived the rigors of the subtropic winter.

The snowclad mountains and the extent of the island in a line from south to north, give to the New Zealander a wide range of choice of climate. On the whole, the climate is mild, equable and agreeable; extremes of cold and heat are unknown. The perpetual snow line is $\%, 500$ feet above the level of the sea. The great forests in the southern part of the islands secure an adequate rainfall throughout the year. During the summer months. from October or Norember to April nr May, the weather is as nearly perfect as can be found anywhere-days of sunsline. with pleasant breezes and rool nights. Mrt. Cook, 13.349 feet, is the highest of the many mountain peaks.

\section{NATIVES.}

The natives of New Zealand are the Maoris. a chivalrous, proud. noble race. They are Polynesians, of the same origin as the inhabitants of all the islands of the South Sea. Their physical and mental characteristics have, however. undergone marked changes since they made their first appearance in New Zealand. Tasman. who discovered the islands in 1642, but did not land, and Captain Cook. who risited them sereral times betreen 1769 and $1 \% \% \%$, found them densely populated 


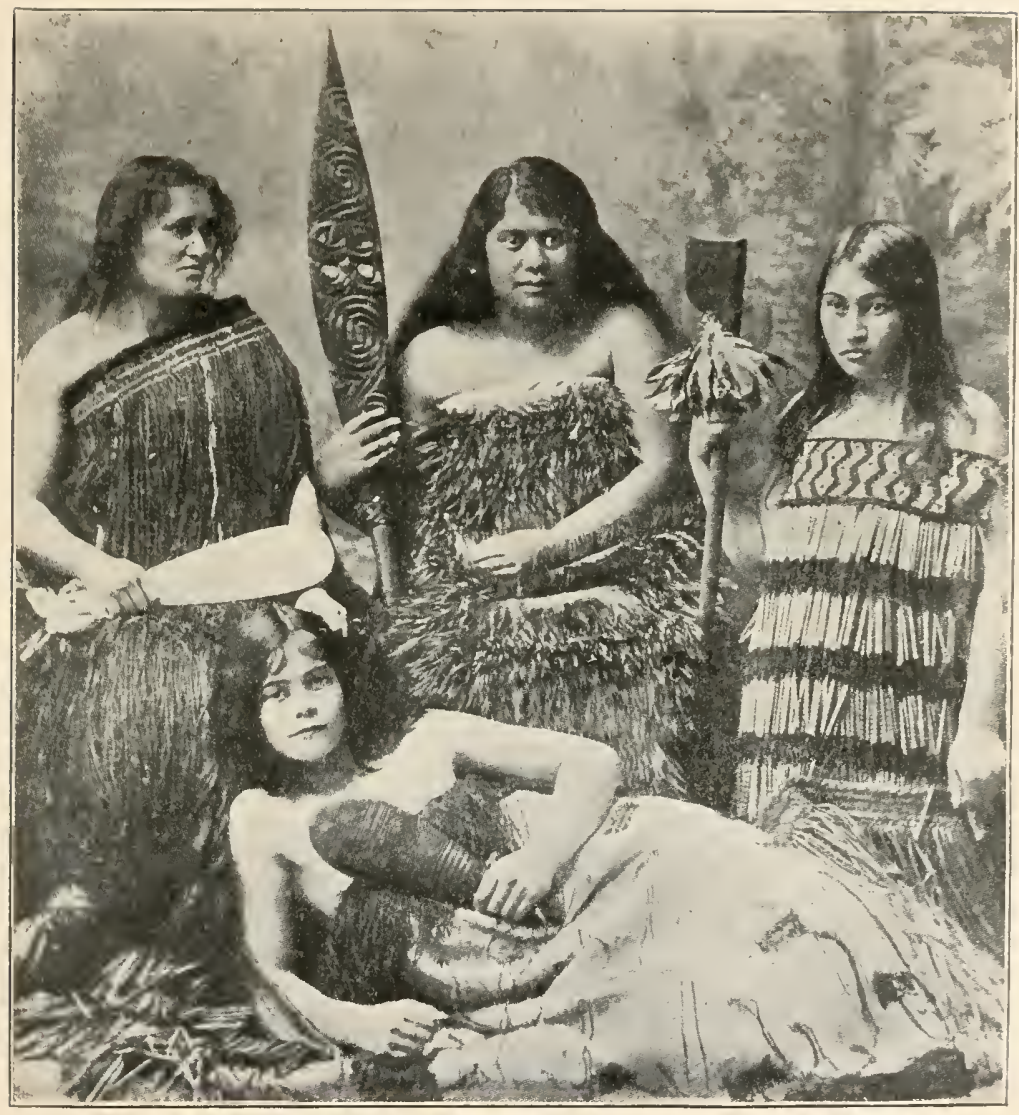

Fig. 21.-Manri women. 

at that time, and nutil subdued by the British they were hardy, war-loving people.

War was a passion with them, but their greatest national characteristic was their love of the land. "Let us die for the land" was their war cry that resounded through all the ages of their possession. Civilization has made them law-abiding citizens of the colonial government and loyal to the king, as was shown during the South African war, when many of them expressed a strong desire to join the British forces. The men are tall, powerful, square. with a brown skin, jet-black eyes, scanty beard, straight or slightly curly hair, with an open, frank countenance. The women are well built, with copious hair, worn in flowing tresses or pompadour, and many of them with handsome features when young. There are about 20 per cent. more males than females. The climate of New Zealand has made its impression on this race. They had to protect themselves against cold by clothing and closed habitations.

The New Zealand flax or hemp (Phormium tenax), a liliaceous plant, from the leaves of which the fibers are obtained, are from 3 to 9 feet long and from 2 to 3 inches broad, furnished them with material for the texture of their garments, as well as the feathers of birds and the skin of fur-bearing animals. The scarcity of tropical fruits and starch-yielding tubers made the struggle for life more difficult than in the more favored islands of the Sonth Pacific, something which could not fail in improving their plysical condition, and in developing their mentality. The Maoris have a taste for art, as is amply shown by their rude wood carvings and the architecture of their houses. Tattooing was formerly extensively practiced, but the operation is performed in an entirely different manner than in Samoa and Tahiti. As the natives have always worn clothes of some kind they select the face, the most exposed part of the body, for the tattooing. The chiefs undergo the most elaborate process of the tattooer's art. With a 
sharp shell lines and scrolls are cut in the superficial parts of the skin, always radiating from the nose, and into these scratches the pigment is rubbed and permanently deposited. The women only tattoo the lower lip and chin in straight lines. Christianity has taken the place of paganism, but is not held with much fervor by the people. Pagan customs and superstition remain. Some Maoris have taken to farming and the professions, but the bulk of the race is living in dull. idleness, depending on the liberal gorernment for their support. The young people realize the advantages of an edncation, and are profiting by the schools located in all of the settlements, as in it they see the only means that will prevent complete extinction of their race. Like all Polynesians. the Maoris have brought their tribute to the altar of cirilization. The acnte infections diseases, syphilis and tuberenlosis, bronght to their islands by the whites, have reduced the population numbering hundreds of thousands. to something like 40.000. In 1891 the native population numbered 43,642 . of whom 2,119 were half-castes. In 1896 the total population of New Zealand was 743.214 , of whom 39.854 were MLaoris and half-castes. Improred sanitary measures and a better appreciation of hygiene by the natives have contributed much in diminishing the mortality among the natives, and will. it is to be hoped, present the extinction of this noble race.

THE CITY OF AUCKLAND.

From the harbor the eity of Anckland, with its orer 60.000 inhabitants. presents a charming sight. It is spread out orer a large surface encircling the capacious harbor and perched on many hills. The two-story houses and cottages are built of brick or wood, and "many of the business houses in Queen Street, the main thoroughfare, are solid structures of stone or brick and coment. Most of the streets have asphalt parements. and are kept scrupulously clean. The electric lighting 
and tramway conveniences compare woll with any of our modern lively western cities. 'The many clurehes, exeellent schools, capacious lospital. museun and public library spoak well for the intellectual life of the island eity. The drive to Mt. Erlen, with its bowlshaped extinet erater, within the limits of the city. is one of great scenic beanty. I made this tour in company with Dr. Lewis in his automobile. I noticed when we made a short stop at the foot of the momntain that Dr. Lewis and his coachman held a short consultation, the significance of which I did not understand at the time. Dr. Lewis steered the French machine. The ascent was slow, and when we came to a few yards of steep grade the coachman lent aid to the quivering vehicle by a vigorous vis-a-tergo until the obstacle was overcome, when the rest of the ascent was made without any further difficulty. When we reached the summit the doctor and coachman shook lands, and the former said in a triumphant tone, "I told you so." It seems that there had been some misgivings concerning the possibility of accomplishing this feat, as the doctor had never attempted it before. His faith in the power of his machine had been vindicated. The view from the summit of the mountain is inspiring. The dizzy depth of the crater and the panorama all around leave deep and permanent impressions on the memory of the astonisher tomrist; the sight of the first is awe inspiring. the contemplation of the surrounding scenery pleasing and full of surprises. From the summit twenty other cxtinct araters can be seen. and the wide expanse of the Pacific on both sides. The well-painted wooden houses and the pale red brick houses. with their silvery roofs of corrugated iron, and the harbor, with its ressels, looked like a toy city made for the ammsement and instruction of children. Eucalyptus and pine trees, the lovely gardens attached to nearly all the houses, and the straight, clean streets added much to the beauty of this fairy scene. The city is supplied with pure water 
from the mountains, and a system of sewerage is now under completion. On an arerage 100 cases of typhoid ferer occur annually. Malaria is almost unknown.

\section{THE ACCKLAND HOSPITAL.}

Auckland has only one public hospital, the Auckland Hospital. It is supported by appropriations made by the general government and the city. The main building was built about fifty years ago. It is built on the summit of a high hill, from which a splendid riew of the harbor and city can be obtained. Seen from the harbor it is one of the most conspicuous landmarks of the city. The city has set aside for it a large tract of land, and the part around the buildings is well laid out in drives and walks. and ornamented by trees, flowering shrubs and flowers. The main building, of brick and cement. is three stories high, with large wards, well lighted and ventilated. A few years ago a Mr. Coatley donated to the hospital the munificent sum of $\$ 160,000$, out of which four brick parilions for women and children have been built, and $\$ 15,000$ is now being spent in the construction of a modern operating room and equipments for the same. This operating room, now nearing completion, will be flushed daily from above, and the skrlight of a domble glass roof is constructed in such a manner that the light will be concentrated at a place corresponding with the location of the operating table. Dr. John C. Collins, the medical superintendent, took great pains to describe this feature of the operating room. as well as its ventilation. By the use of an electric apparatus the air of the room can be exhausted at any time it becomes contaminated. The operating room used at the present time is on the first floor, but is inadequate for modern requirements. The medical staff is composed of three physicians, three surgeons, one oculist and aurist. no gynecologists and no obstetricians. The hospital proper and parilions ean accommodate 210 patients. Patients with means are required 
to jay, the amount depending entirely on their meins. A charming feature in the wards of this hospital is an abundance of fresh-cut flowers on high, narrow, long tables at the foot of the beds in constant sight of the patient when awake. The hospital has its own training school for female nurses, with an attendance of 64 at the present time. They are in training for three years, but receive a small compensation after three months. Among the interesting surgical cases shown by Dr. Collins were the following: A Maori who, by the accidental discharge of a shotgun he was handling. shot away the larger part of the hody of the loft side of the

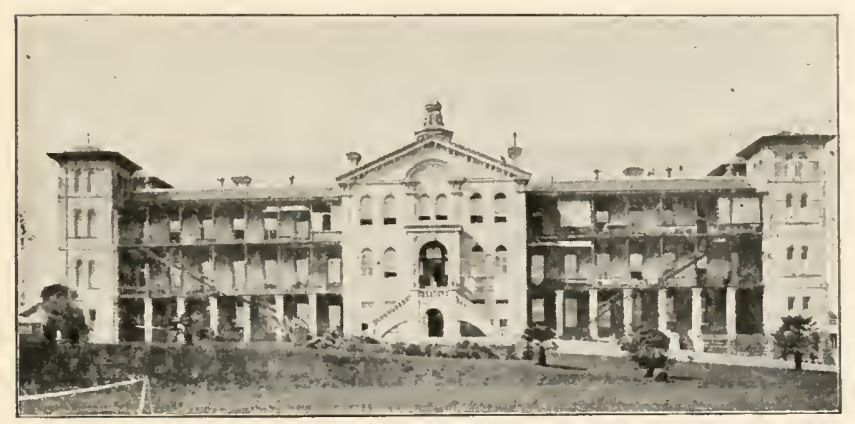

Fig. 2--Aucliand Hospital.

lower jaw. Edema of the larynx was threatened, and a tracheotomy was made. At the end of twenty-four hours the tube was remored, and although the left side of the face remained greatly swollen, he is improving rapidly. Several cases of compound fracture; resecton of cecum for tuberculosis: gastroenterostomy for stricture of the pylorus; extensive fracture of the skull in a boy, for which trephining was performed. On an arerage about 100 laparotomies are performed in the hospital every rear by the different attendiug surgeons. This comparatively small number of abdominal operations, however. loes not represent the bulk of this kind of work done in the city as only the attending staff is 
permitted to operate in this institution, and many of these, and all other physicians perform their operations on private patients at their homes, or in one of a number of little private hospitals conducted by nurses. There seems to be no manimity among the surgeons in the ne of anestheties and suturing material. Chloroform, ether and A. C. E. mixture are used as anestheties, and silk, silkworm gut, catgut and kangaroo tendon as suture material according to the preference of the different operators.

THE MEDICAL PROFESSIOX.

I had abumlant opportmity to experience that the medical profession of Auckland is erorlial and hospitable. Dr. Edward IV. S. Sharman. the fuarantine physician of the port, after completing his inspection of the stcamer, took me ashore in his steam lannch, and from there directly to Dr. 'I'. Hope Lewis, the most frominast surgeon of the eity. To these two yentlemen, who gave me their whole time diming the entire afternoon, I am greatly indebted for what I saw and learned in their city. There are 40 practitionors in lucklancl. 'There is only one specialist for the eye and ear. All of the plysicians do their own operating, including all kinds of grnecologie work. Dr. Trwis is the only one who is gradually learing general practice. and wi]l soon devote himself exelusively to surgery. The fees in Inckland are not high. Tisits are charged for accorling to the patient's means, from ac to $\$ 2.50$. The m:ximmm figure is very seldom porched. For any eapital ofuration \$2s0 is regurded. eren ly the wealthy, as a very large foe and most of the diffieult operations ale paid for at the rate of $\$ 100$. Wrot of the physicians aro graduates of Fnglish and Seoteh miversities, and

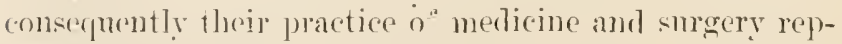
resents the teachings of Britisl anthoritios. They are all members of the British Medieal Society, and depend for the current modical literature laredy on its official 
organ, the British Medical Ionrual. The New Kealant] branch meets once a year. and the city, or local brancli, monthly. These meetings are well attended. and the transactions represent the clinical and scientific work of its members.

Sroney, Iustralia, July 30, 1904 . 

AUSTIRALIA.

ITS CLIMATE. DISEASES, PEOPLE, NATIYES. SYDNEY, HOSPITILS, MEDICAL PROFESSIOX.

The voyage from Auckland to Sydney takes four days. The first two days we encountered a strong northwesterly gale which, on shifting to southwest. brought with it the cold breath of the sonth polar region. Sailing in a southwestern direction the cold gradnally increased until we entered the magnificent harbor of Sydney, Saturday evening, July 30. It was soon after leaving Auckland that it became apparent that we were in the vicinity of an entirely new world. with strange animals, trees, plants and flowers. by the appearance of a rare and strange bird-the albatross. About half a dozen of these giant sea-gulls accompanied us from coast to coast. but carefully avoided the harbors. It is a magnificent bird with snow-white bodr, yellow straight bill. the upper part of which at its distal end is bulbous and its tip sharply curved downward. overlapping the lower; the enormous wings, measuring from tip to tip from eight to twelve feet, are white underneath, and the upper surface brown with the exception of its inner fourth, which is also white. These birds live on waste material which is throw overboard by the passing vessels. They fly with and against the wind nearly with the same velocity and with very little effort on their part. three or four strokes of their immense wings sufficing to start their graceful sailing movements, and by poising their body and wings in proper attitude they ascend, descend and make all kinds of curres and circles with little if any effort until a few actire movements of the wings again become necessary to keep up the necessary momentmm. They are very fast flyers. and multiply many times the distance 
made by the steamer in their ceaseless to-and-fro flights in search for the very irregular and often seanty food supply.

Many people are still under the erroneous belief that Australia is an island, and few, indeed. have a correct conception of the magnitude of this great continent, which probably emerged from the bosom of the Pacifir. Ocean before the other continents saw daylight. It is nearly as large as the United States, inclusive of Alaska. Australia was first discovered by the Dutch and Spaniards in 1601-1606, and Captain Cook visited it in 1880, entering Botany Bay, near where Sydney is now located. April 28, where he landed and took possession in the name of King George III. For a long time England used it as a penal colony. There is perhaps no other country that presents to the stranger more characteristic features than Australia. Many things are the reverse to those who live north of the equator. When we have summer it is winter here. The tropical part of Anstralia is in the north and the frosts and occasionally a flurry of snow in the south. The crescent of the moon appears to us turned around. The animals are strange. It is the home of the strangest of all known animals, the duek-bill platypus (Ornithorlyyrdus jurado.tus), which forms the connecting link between quadrupeds and birds. It is about two feet in length, has a flat black bill, webbed feet and body covered with a brown, silky fur skin like a beaver: it lays egres and supplies the yomng with milk from its breasts. Australia is also the land where the giant emu (Droners norre-hollandice) lives, a bird with only rudimentary wings ant in size as large as the ostrich of Africa. Among the other strange animals there are the kangarno, the wallaby, the kaugaron rat, flying fox, blind snakes and a small species of bear not larger than a gninea-pig, and the cassoway, a turkey as large the emu, and more than sixty varietics of parrots. The regetable kingdom is characterized by its great variety. The vast 
forests are composed of eucalyptus trees which are evergreen, but instead thed their bark annually; 400 varicties of this tree have heen described; more than 10.000 of its imligenoms plants have been classified. The great variety of the fauma and flora of Australia alone shonld be a sufficient inducement for all those who take interest in natural history to visit this land so full of nature's strangest productions, all of which secm to point to the great age of this part of the world.

THE KANGAROO.

The kangaroo is a striking freak of Australia's fauna. For the purpose of increasing its speed, its only defense. nature has supplied this animal with a fiftl leg in the form of a long and porrerful tail. Shorten the ears of one of our jack-rabbits one-half. lengthen the hind legs four times and ard the tail of a kangaron and it would be converted into a kangaroo on a small scale. This animal has a special inferest for the surgeon. as the numerous delicate tendons of its tail have supplied a. good substitute for catgut as a suturing and ligature material. For more than twenty years my friend. Dr. H. O. Marey of Boston, has expounded the rirtues, adrantages and use of the kangaroo tendon in surgery, and through his influence it has become a rely popular substitute for catgut in the practice of many American surgenns. I was somewhat astonished to find that American surgeons entertain a more favorable riew of the utility of the kangaroo tendon than their Australian colleagues. Some of the latter never use it. some necasionally. and rery few, if any, me it exclnsirely. It will interest the derotees of the kangaroo tendon ligature and suture to know that what they have heen using is. as a rule, not the tendon of the kangaroo. but of the different species of wallaby. The kangaroo tendon is very coarse, at least the size of an old-fashioned knitting necdle, altogether ton large for general use. The wallaby is a rery much smaller animal of the kangaron 
family and yields a much finer material. There are three large species of kangaroo-the red kangaroo (Macropus rufus), the great gray kangaroo (Macropus giganteus), Bennett's tree kangaroo (Dentrologus Bennettianus). The wallabys that furnish the tendon supply are represented by Parry's wallaby (Macropus Parrei), agile wallaby (Macropus agilis), brush-tailed rock wallaby (Petrogale pencillata), black wallaby (Macropus robustus). The rat kangaroo has a tail like a kangaroo and its fine, extremely delicate tendons, I am informed, have been used by some ophthalmic surgeons. The real kangaroo has become quite rare, as their skins are valuable and the price paid to market hunters was a sufficient inducement for them to carry on a war of extermination. For the same reason the wallabys have also become much less numerous. These animals are now protected during certain seasons of the year, which will, it is to be hoped, prevent them sharing the same fate that we meted ont to our buffalo. The tendons are obtained by divesting the tail of its skin, cutting off its tip, grasping each tendon with forceps and extracting it with a jerk. The proximal end of the evulsed tendon is a little larger and more flattened than its distal end.

\section{CLIMIATE.}

The Australian has a wide range from which to make a selection of climate, as it is influenced by latitude, elevation and distance from the coast. Floods and droughts are the bad things which have seriously interfered with the continuous prosperity of the country, and they likewise have a decided influence on the climate. The northern part of Australia is tropical and has a tropical climate. and the vast forests secure for that section of the country an abundant rainfall and a luxurious vegetation. In the vast dry plains of the interior the heat during the summer months is intense: here the thermometer has been known to register as 
high as 140 degrees F. The Australian Alps consist of a range of mountains in the southeastern part of the country called Warragong by the natives. The highest peak is Mt. Kosciusko, which rises to an elevation of 7,176 feet. This forest-clad mountain range has a decided influence on the climate of the surrounding country, breaking the force of the icy winds from the south in winter and the land breezes from its summit moderating the heat during the summer months. The climate of Sydney is very much like that of Naples, with a mean annual temperature of from 58 to 62 degrees $\mathrm{F}$. Frosts in winter are common; the highest temperature in summer does not exceed 104 degrees F. At Melbourne. 500 miles south of Sydney, very thin pellicles of ice are sometimes seen during midwinter on small, quiet pools of water; the summers are decidedly cooler than in Sydney. At Sydney the average annual rainfall is over 49 inches, and during the summer, from December to the beginning of March, the sky is cloudless and the nights generally cool, sufficiently so to remind the people of the use of woolen blankets. For the American visitor winter is the proper time to see Australia, as he will then escape our summer heat and will enjoy the Australian winter with its flowers and invigorating cool breezes.

\section{PREVAILING DISEASES.}

With few exceptions the prevailing diseases of Australia are the same as of our middle states. It has escaped the ravages of cholera. Sydney recently has had a number of cases of bubonic plague, but the rigid sanitary precautions resorted to by the board of health have succeeded in stamping out the disease. Malaria is met with only in the tropical part of the country. Pneumonia of a very virulent type occurs most frequently during the winter season. Acute articular rhenmatism is quite rare. Influenza, scarlatina and measles make their appearance from time to time. Typhoid fe- 
rer appears to be more frequent in the country and villages than in the large cities, as the latter have an excellent water supply. At Melbourne this disease is most prevalent during the holiday season, when the people leave the city for their vacation and live in the country towns. where the danger of infection from contaminated water is much greater. Isolated cases occur in the cities and can nsually be traced to infected wells, which are still in use in parts of the cities that remain outside of the reach of the regular water supply. The skill of the medical men is well shown by the very low mortality which attends this disease and which does not exceed 6 per cent. Prof. F. D. Bird has operated on three cases of typhoid fever in which a fatal termination from sepsis was imminent. He opened the abdomen. where he found a small quantity of serum. flushed with a hot saline solution. closed the wound and had the satisfaction of saving all of them. marked improvement heing noticed as soon as the patients recovered from the immediate effect of the operation.

Tuherculosis of the lungs. joints. hones and lrmphatic glands is met with in about the same frequencr as with us. Leprosy prevails to some extent in Sydner and its ricinity. There are at present $1 \%$ cases in an isolation hospital on the coast at Botany Bay, sereral miles from the eity. If a patient affected with leprosy has sufficient means to support himself in a house sufficiently isolater from other habitations he is not molested: if this is not the case he is compelled to seek the shelter of the "leproserr." Although actinomycosis is quite a frequent affection among cattle it is almost $u n k n o w n$ in man. Rlastomycosis is rery rarely seen. Not a single case of hydrophohia has ever been seen in Australia. although it has a large dog population, and the ringo or wild dog is numernus, as well as other animals capable of transmitting this disease. Tetanus is not more common than with 11. . Tn every large hospital from two to four eases are treated annually. In 
the acute form of the disease antitetanic serum hals been found absolutely worthless as a curative agent. Hydatids are very common in the sonthern part of Australia, Adelaide and Sydney furnishing the largest percentage. The plyysicians attribute the disease to the drinking water. It affects most frequently the liver and lungs, but spares none of the internal organs. Operitions on the brain for hydatid eysts figure in almost every hospital report. In all of the museums may be seen beautiful specimens of hydatids of the bones obtained by operation or postmortem specimens illustrative of the extensive destruction of the entire shaft of the large long bones. It is also frequently found in the faseia and omentum. The disease is rery rate in Queensland, resembling the geographic distribution of the disease in Germany, where it is very common in the northern part and rare in the southeru. It has been observed in children from 3 to 4 years old. It pursues a more rapid course in the young than in the aged. Its course varies in different individuals. It may become latent when the eysts shrink and the symptoms subside. As the disease is often multiple, more especially in the liver and omentum, a number of operations may become necessary, as the surgeons have learned by experience that it is not wise to undertake too much at one time. Dr. Bird operated on a patient suffering from hyrlatids of the omentum nine times before he was able to eliminate all the cysts. The $x$-ray nerel fails in locating evsts affecting the upper surface of the liver: this diagnostic resource invariably vields a negative result when the under surface is affecteu. The methors employed in operating for hydatid cysts of the liver are not uniform. Dr. Bird cuts down on the crst. makes a free incision. inserts the index finger, bringup the margins of the cut and stitches them to the cxternal wound, extracts the lining membrane and drains. In operating for a crst on the upper surface of the liver he resects a short piece of the eighth rib 
near the costal cartilage and through this wound deals with the cyst in a similar manner. He always drains. I)r. Fiaschi of sydney, on the other hand, is in favor of suturing the wound at once, without drainage. In nine cases he was obliged only once to reopen the wound. It the Children's Hospital in Melboume it has been observer that in 90 per cent. of the cases of hydatid evsts operated on an urticaria develops in from a few minutes to two hours after the operation, which disappears in the comrse of from one to two days and which is attributed to an intoxication by the contents of the crst absorbed from the wound surfaces or the peritoneal cavity. The contents of monocysts are much more virulent than eysts which contain daughter cysts. In rare casces after tapping or operation, specdy death from this canse takes place; tapping has consequently been abandomerl.

\section{THE PEOPLE.}

Most of the original settlers of Australia cane from Fingland. Sotland and Ireland. These people have con*rrel their habits and customs to a large extent. but in the conrse of time a new generation has grown up whose methods of life have heen molrted by climate, ocempation and enviromments. The English, Scotch and Irish accents have not suffered on Australian soil: if anything, they have beeome accentuated, more especially the English. This aecent is bad enougl in London, but is worse here. In rapid conversation some words are mintelligible to the American. It loes not take long for the stranger to find this ont, as all he has to do is to tackle one of the big policemen and ask him for directions to find a certain street or place of business, and he will have to listen very attentievly to intreporet his hrogue. The real Australian is determined to make the hest of the present and enjoy life. Mis desire for great wealth is a rery morlerate one, and he will not sacrifice luis personal comfort to obtain it. $\mathrm{He}$ 
is satisfied with an income that will insme for loim an easy existenes and the cherished persomal romlonts. He agrees with oncenalis:

"Wretched is the guardianship of a large fortume."

Yon will fail to find here the carrworn, determined faces that throw a gloom over the restless throngs that crowel the streets of Chicago and other great American business eenters. The Anstralians are excessively fond of outdoor sport. Men and women, roung and old. are comally determined to throw away the cares of life as often as possible and enter with heart and soml into the enjorment of all sorts of outdoor sport.- Every saturday noon business is suspended and the whole afternoon is deroted to pleasure. Yachting races, bascball, golf and ericket are the most popular outrloor amusements. On the Saturday 1 was in Sydney 30,000 people attended a game of baseball, and, as a yacht race was going on at the same time and the many events elsewhere were well patronized, it is evident that nearly every family contributed its slare to the rast ontdoor crowds. Sunday is respected as a day of rest. All shops and saloons are closed. In the morning the chmrehes are filled to overflowing and during the hours of worship all tramcars come to a standstill. In the afternoon the honses are deserted and the people congregate in the many public parks, botanical and zoological gardens. The Public Domain, across the street from the Botanieal Garden, is the place for the stranger on Sunday afternoon if he is desirous to obtain a good idea of Australian life. On the Sunday I visited this park, which includes about forty acres, I found a moving sea of hmman beings, in the center of which a military band plared martial music. A short distance from the periphery of this immense gathering were smaller groups in all directions. 'The first one I approached was an oldfashioned Methodist exhortation meeting, with a leader on one side of the small open space. After each stir- 
ring song someone would step forward and in a few words relate his religions experience and eneourage others to do the same. Almost within hearing distance of these revivalists was a much larger erowd listening to a fiery political speech, the subject of which was the pending election. In the middle of the next group, and it was not a small one, a tall, lean. long-bearded man was discoursing on personal magnetism, illustrating his smooth talk with crudely drawn pietures. $\mathrm{He}$ explained to the gaping men, young and old, the mysteries of love and how to prevent shipwrecks in the matter of the selection of a partner fer life. He had fathomed the human heart to its very depth and evidently had his share of this world's experience. For the time being he gare his advice free and liberally. but undoubtedly at the end of his harangue he supplied his audience with his address so that they would have no diffieulty in finding him to obtain further details. Sereral fake physieians were expounding the virtues of their specifie remedies. which would cure all kinds of chronic diseases which still baffle the skill of the medical profession. These men had their stuff with them and were lining their pockets with silver. The next orator was talking to a large crowd of laboring men on the evils of monopolies and our billionaires received their full share of condemnation. The Salvation Arny and temperance people were also well represented in this complex of gratuitous humane endeavors. In the evening the great thoroughfares presented a similar spectacle. Australia has more than its share of orators who firmly believe in the power of eloquence.

"Nothing appears to me nobler than to keep assemblics of men entranced by the charms of eloquence, wielding their minds at will, impelling them at one time, and at another dissuading them from their previous intentions."--Cicero.

The orderly behavior of the people and the close attention they paid to the speakers is deserving of well- 
merited praise. W'luat Australia needs to Aevelop its slumbering resomes and to increase its prosperity is a larger population. The present population of this great country is less than $5.000,000$, and statistics slow that for the last ten years it has rather decreased than increased. Japanesc and Chinese immigrants are, by a recent act, absolutely excluded. For some time these yellow people paid $\$ .500$ for the privilege of entering the country. Abject poverty and begging are almost unknown. All classes of people take a keen interest in edueational and charitable institutions. The typical Australian is neither a European nor an American; he exhibits qualities that indicate the geographical location of his country half-way between the European and American continents, from each of which he has assimilated habits and customs which characterize his thought and action. He has acquired the business tact of the American and retains the love for recreation and amusement of the Europeans.

THE NATIVES.

The aborigines of Anstralia appear to be quite a diotinct race and luave nothing in common with the South Sea Islanders. They bear a eloser resemblance to the Africans in the black or dusky brown color, thick lips, short, flat noses, narrow, high and sloping forehead, copious growth of jet black, straight hair. Mentally they are far beneath the Polynesians. (Fig. 23.) They live a nomadic life, without a permanent habitation, and rely on fish and game for sustenance. They were a fierce, warlike people who with spear, arrow, clubs and boomerang fought the whites persistently until they became convinced of the utter uselessness of their efforts to resist the superior force of the invaders. Even now the natives of Queensland in the dense forests and jungles occasionally show a hostile attitude toward the pioneers in the steadily advaneing line of civilization. The natives, who numbered hun- 
dred- of thousands when the white man took possession of the country, as the result of a war of extermination. and acute and chronic infectious diseases introduced by the whites, have been reduced to a rery small number. The census taken in 1902 shows that the present native population consiste of 5.9 .1 si black and i.128 balf-castes. The Tasmanians fared even worse than this. In 1803 the island hat at least 5,000 inbaloitants. The whites began a war of extermination which lasterd thirty rears. The crud: implements of

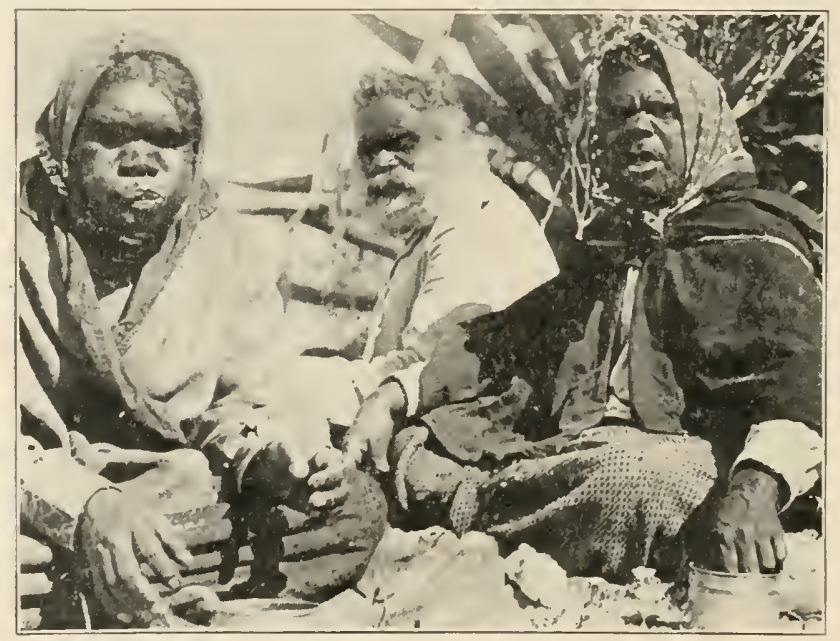

Fig. 2a.- - Instralian aborigines.

native warfare proved powerles against the firearms of the invarlers. and when resistance ceased there were few left to relate the story of the heroic strugrgle marle in the defense of their beloved island, and the whites conld ease their conseience by asserting:

"It i- the right of war for conpuerors to treat those whom they bave conquered acoording to their pleasure."-C'cesar.

The race became extinct with the death of the last Tasmanian in 18\%6. Snch is the cruel fate of the 


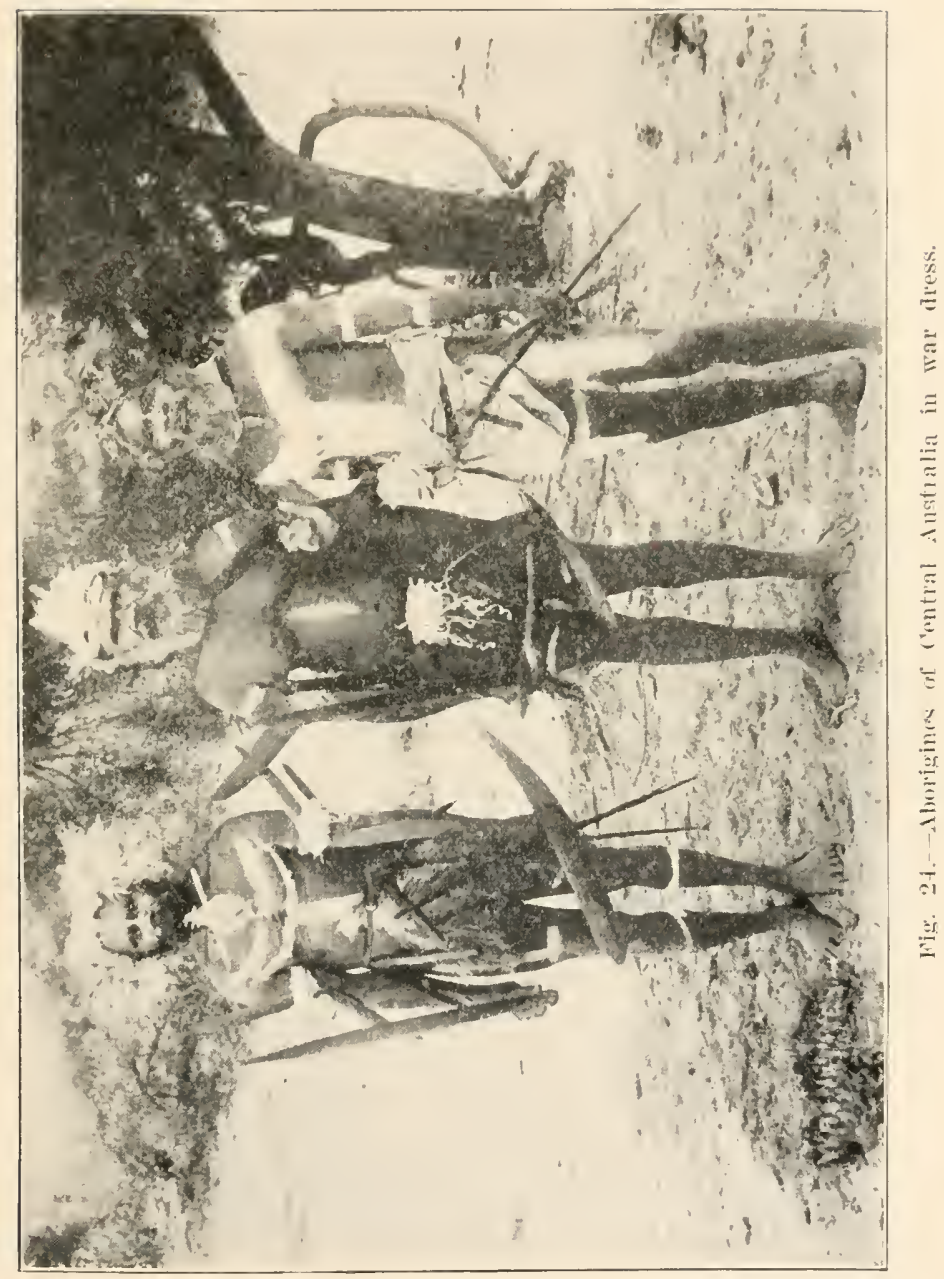



primitive races. 'Tuberculosis and sypluilis are doing their insidious, deadly work among the survivors of war and the ravages of acute infections diseases, and their complete extermination is only a question of time.

TIIE MIKA OIR KUIPI OPERATION.

'This eustom was first noticed by Eyre (184.i) in the comntry around the great Australian Bight, and is well deseribed by Professor Stuart of the University of Sydney in a paper read before the Royal Society of New Sonth Wales, June 3, 1896. The operation practically consists in, generally at the age of puberty, cutting the floor of the urethra so that it is slit completely open from below, the cleft sometimes extending only halfway back, sometimes the whole way back to the scrotum. Sometimes a mere perforation is made. The intent of the operation is to prevent impregnation, and came into use as a safeguard to prevent a too rapid increase of the population, serving thus a useful purpose in diminishing the struggle for existence. The operation consists in creating a partial or eomplete hypospadias. "The incision is made with a sharp-edged piece of quartz, shell, flint, or, in more recent times, glass. These, fixed with resin, twine, etc., into handles, constitute the 'mika-knives.' The bleeding is stanched with sand, and the edges of the wound are burnt. Lemholz says, with hot stones-perhaps, as Etheridge suggests, to cauterize them-and keep from adhering again and healing by being kept apart with bits of stick. wood, bark or bone inserted between them, or by being filled with clay, or by being rubbed with a broad-edged stone." The operation constitutes a kind of a ceremony and is performed sometimes eight days after birth, but more frequently between the ages of 14 and 18 . The men thus operated on are given privileges that are not within reach of the non-kulpi men. In regard to the effect of this mutilation on the chances of impregnation opinions differ. Eyre, who first described this con- 
dition, says: "This extraordinary and inexplicable custom must have a sreat tendency to prevent the rapid increase of population. and its adoption may perhaps be a wise ordination of Providence for that purpose, in a country of so descrt and arid a character as that which these people oceupy." Profesol stuart summarizes his very instructive paper in the following conclnsions: 1. Nothing whaterer can be refinitely stated as to the origin of the eustom. ?. The operation does not. necessarily render the man sterile. It merely diminishes his fertility : what the degree of diminution may he will depend rutirely on ciremmstances.

THE SELYITING IBORTRINES.

A large number of native still live in uncxplores? parts of northern Anstralia in their original state. 'Tle civilized portion has become a gorernment charge like our Indians. They are extremely lazy and depend almost entirely on the goremment support. (Fiw. 2.5.) I visited two of these settlements, one at La Peronse on Botany Bay. suren miles from Srdney. and the other at Coranterrk. near Healeville. forty miles from Melbourne. At each of these places there are about sixty persons, most of them half-castes. The first eolony lives on a fl-acre tract of land: the latter has 5,000 acres set aside by the government for their exclusive use. At La Perouse they live in small huts made of corrugated iron: at Healeville there are small frame or brick houses. Some of the oldest members of these settlements retain their original trpe and were children when Sydney and Molbonrne were villages. All of them speak Fnglish and the children have lost the language of their parents.

SYDNEY.

Sydney is a profperous, growing city with 4,50,000 inhabitant:. The louses are built of stone. lrick and cement or brick alone. Most of the main thorough- 


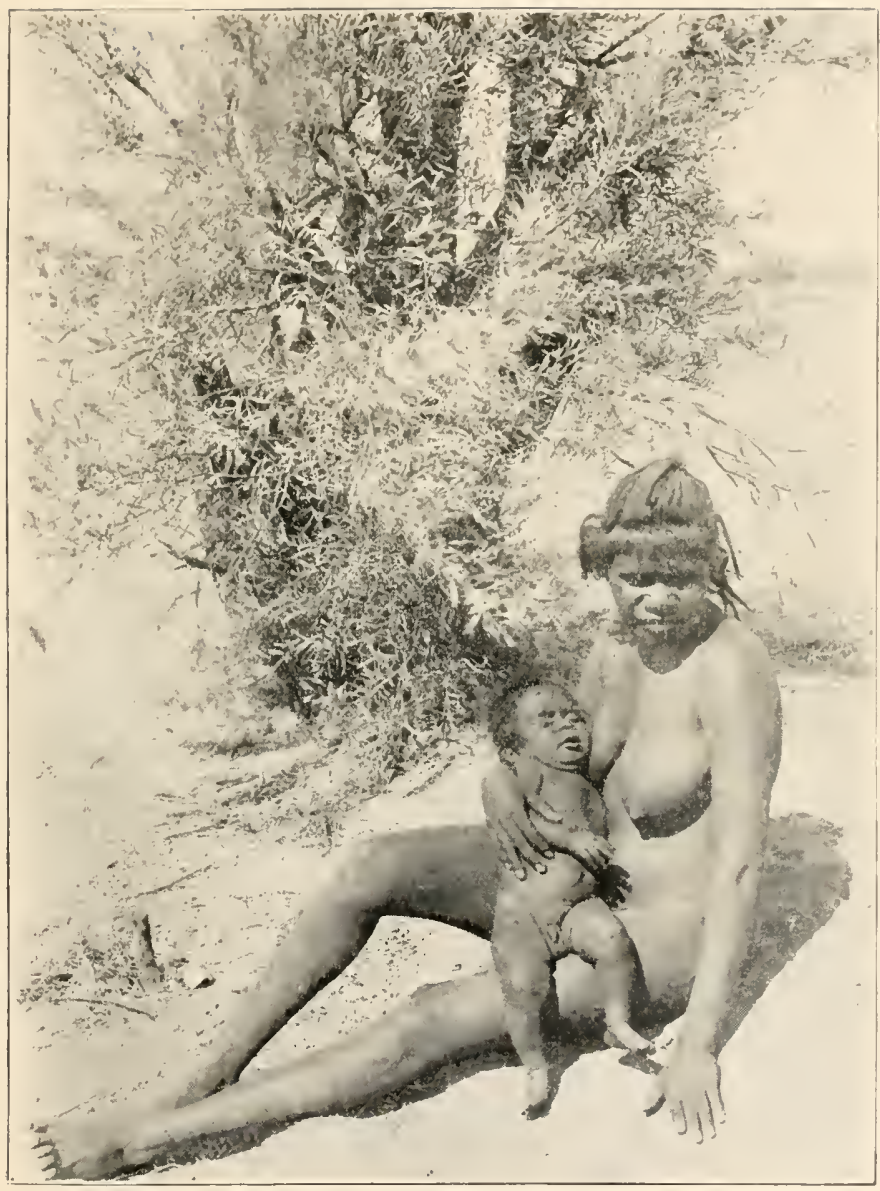

Fig. 2.- Young native mother and infant. 

fares are pared with hardwood blocks, the space: between them filled with cement. The electric lighting and electric tram system, water supply and sewerage, the many public parks, library, muscum, botanical and zoological gardens are the best proofs of the widespread public spirit of its citizens. The university, public and private schools, hospitals and other charitable institutions and the many churches speak well for the intellectuality of its people. The location of the city on the hills inclosing the magnificent harbor compares well with Naples. The country around Sydney surpassed all my expectations. Dr. Hinder gare me an automobile ride of sixty miles and we passed through a country dotted with orange groves and fruit orchards, and a part of the faultless macadamized road led over mountains 900 feet high. through rirgin forests skirting dark, deep ravines, with inspiring glimpses of country scenes in the far distance. The orange trees are small and not orer six fect in height, with dark green, shining leaves in such strong and beautiful contrast with the heavy burden of golden fruit. The forest, or, as it is here called, the bush, was resplendent with flowers of all hues and blooming shrubs.

\section{HOSPITALS.}

Sydney has made ample provision for its sick poor. The public hospitals are supported by donations and annual subscriptions; the latter are doubled by the government, besides the government pays for each charity case $\$ 5$ per week. None of these hospitals has private rooms, but the patients who have means pay what they can toward their support, the maximum charge being $\$ 5$ per week. Medical and surgical service is rendered gratnitously by the members of the staff. The lack of private rooms in all of these institutions makes it necessary to establish private hospitals, a number of which are conducted by nurses; others are owned and managed by the surgeons themselves. 
SYDNEY HOSPITAL.

The Sydney IIospital was founded in 1814 and the original building remains as a wing of the new building. It is a masive three-story stone building, adjoining the Honse of Parliament. It is the largest of the hospitals, the number of beds aggregating 460. Two large marble tablets in the main hall are inseribed with the names of its donors in gilt letters. The smallest anount that entitles a person to this distinction is $\$ 250$; the largest contribution among the more than 100 names I noticed was $\$ 11,500$. The ceilings are high and the wards well lighted and ventilated. Scrupulous cleanliness prevails throughont. There are two operating rooms, one for aseptic, the other for septic cases, and both are well equipped for modern work. Fther is the favorite anesthetic and biniodid of mercury, 1 to 500 , is used for hand disinfection, and catgut has the preference over kangaroo tendon as a suturing and ligature material. In the surgical wards I found many cases of fracture and excision of joints. Plaster of Paris is used extensively as a fixation material, both in the treatment of fractures and after resection of joints. Hip-joint resections are usually made throngh the anterior Inecke incision. Asepsis is carried ont in a thorough manner, as was evident from the many primary wound healings I saw. The medical staff is assisted by ten internes, graduates of the Syrney University. The appointment of intemes is made on the merit of their standing in their college work. Those who have the best record go to the Prince Alfred Hospital; the Syrlney Hospital has the next choice. then come the remaining hospitals. The internes receive a small salary, serve for one year and receive the henefit of all department- by transfer every three montlis. The Sydney Hospital has an excellent training school for female nurses. which occupies a separate wing. the Nightingale wing. The eourse of training 


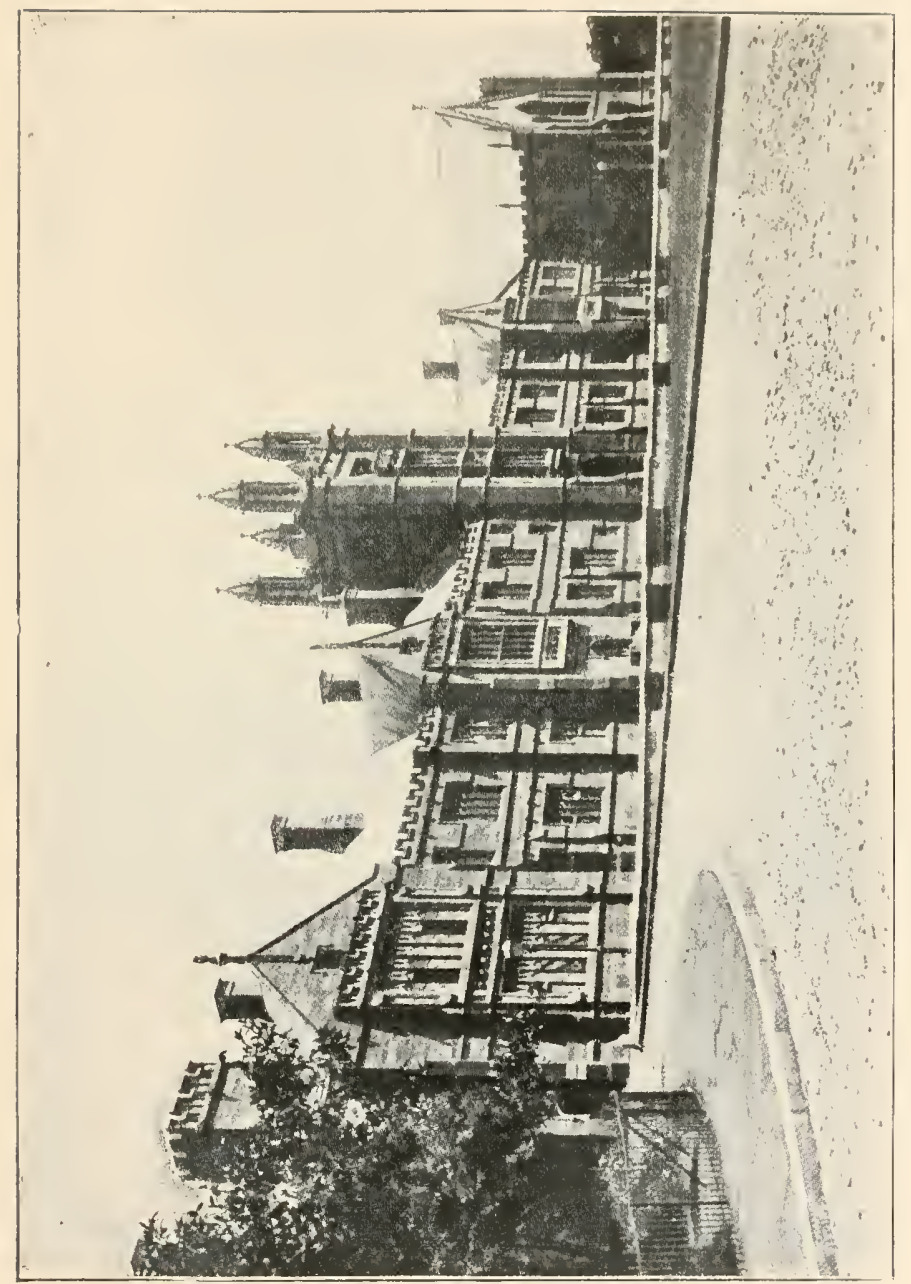

告 


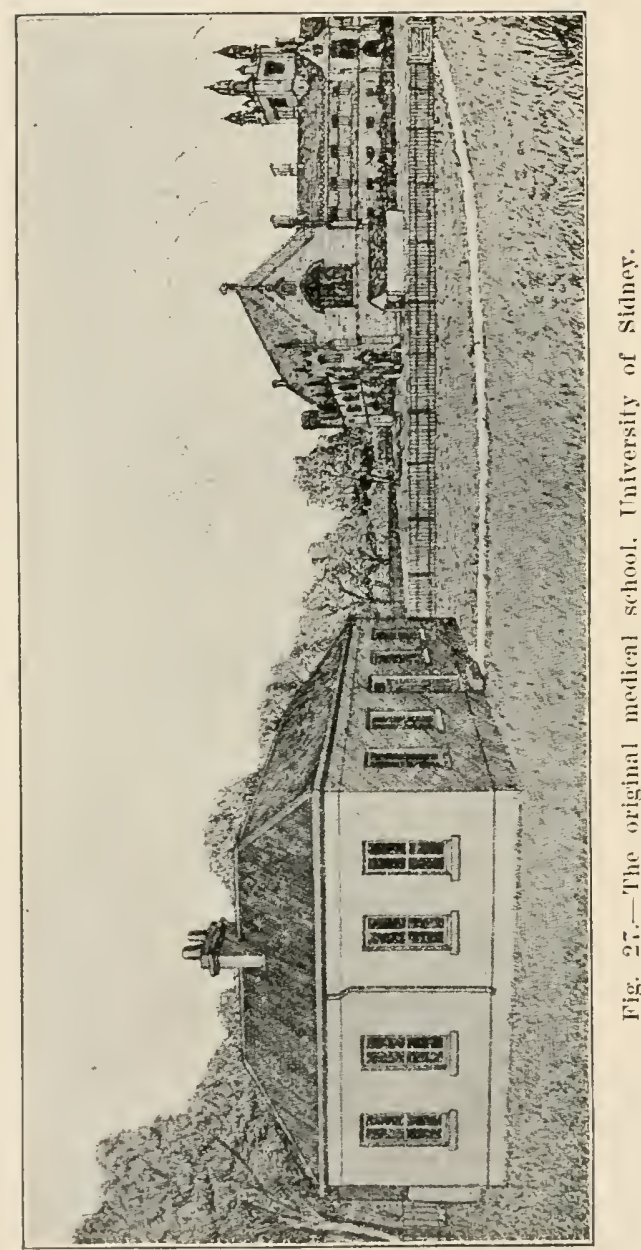


extends over four vears. The nurses are in charge of a matron and five Protestant sisters. 'They receive a small compensation during their pupilage. A wellequipped laboratory and a complete Roentgen outfit add much to the scientifie work of the institution. "The attending surgeons are called "honorary surgeons." "The proent surgical staff consists of W. Chisholm, M.I). Londou. M.R.C.S. England: T. Steer Bowker. T.R.C.P. Elin., M.R.C.S. England: Thomas Fiaschi. MI.D. ant M.Ch. Tnir. of Pisa: H. L. Maitland, M.B., Ch.M. Syiney. 'The medieal staff has an equal number of

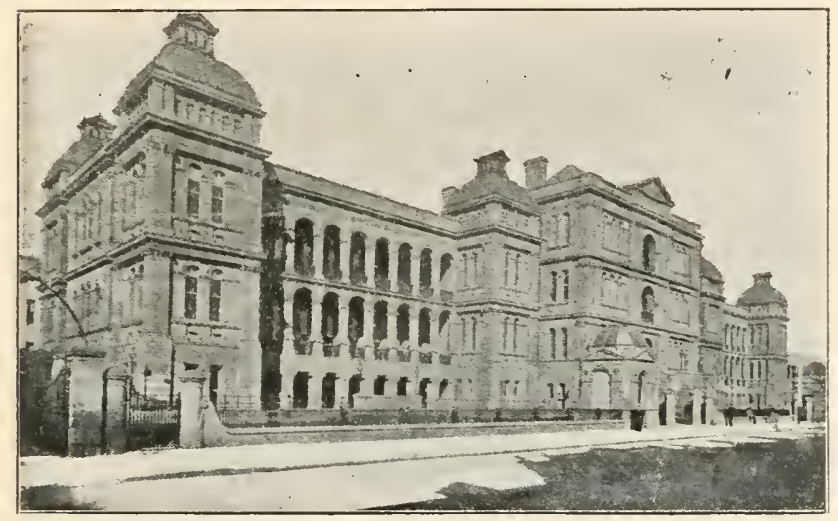

rig. 2S.-Tiew of syolney IIospital from the Northwest.

nembers. 'The specialists are well represented in this: institution. A rery interesting featme in this hospital is the meeting of all attending men for consultation crery Tuesday erening. It these meetings cases are presented and difficult diagnoses settled. and arivice freely given as to the best treatment to be pursucd. This phase of the medical service has much to recommend for imitation in our great hospitals. Dr. Fiaschi, who conducted me throngh the hospital, showed me many cases of gastric and intestinal surgery, all doing well, and a number of cases of hydatids recently operated on. Operation for stone in kidney and bladder 
and removal of hypertrophied prostate are of very frequent occurrence. Dr. Fiaschi is in favor of the suprapubic route in both of these operations, while some other surgeons prefer the perineal in performing prostatectomy. I was somewhat surprised to learn that the ligature remains popular in operations for hemorrhoids. The annual report shows that 19 cases of hydatids were operated on, with no death. Of these cases 13 involved the liver and the remaining other parts. Of 8 cases of prostatectomy 5 were cured, 1 relieved and 2 died. No mortality in 20 ovariotomies and only 1 death in 12 cases of operation for myofibroma.

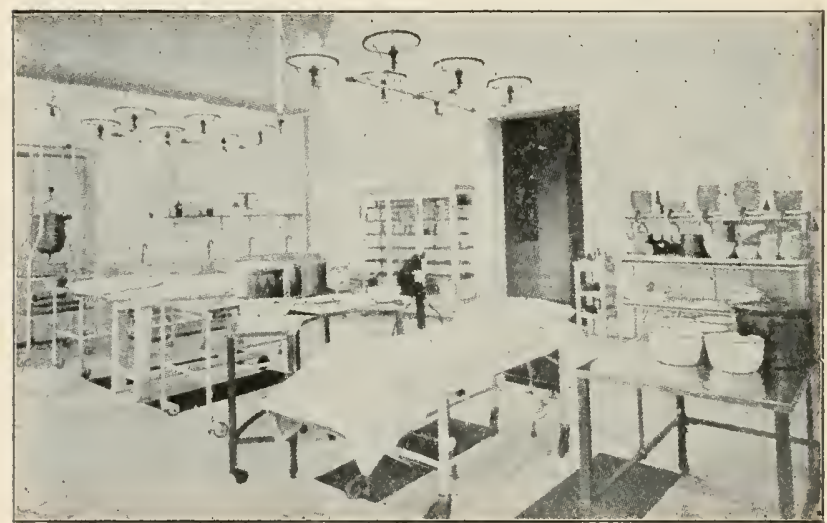

Fir. 29.-The operating theater, Sydney Hospital.

\section{ROYAL PRINCE ALERED IIOSPITAL.}

This is a modern hospital in every sense and has accommodations for 250 patients. It is a solid red brick building three stories high, built on the pavilion plan. It is in this hospital that the students of the Sydney University receive their clinical teaching and training. It was founded in $18 \% 1$ in memory of the Duke of Edinburgh, who visited Australia in that year and was wounded by a crank, who shot him. It was framed as a general hospital and medical school for the instruction of students attending the Sydney University, 
and for trainiug of nurses for the sick. It is managed by a board of fifteen directors. The chancellor of the university and the dean of the facnlty of medicine are directors ex-officio; three directors are appointed by the government and the remuining ten are selected by the government and subscribers. The medical officers are all appointed by a conjoint board, consisting of the senate of the miversity and the directors of the hospital. The selection is made from the teachers of the medical school and the appointment is made for six years. The medical staff is composed of three physicians, three surgeons, two gynecologists, one ophthalmologist, one dermatologist, one rhinologist and aurist. A resident medical superintendent and six internes reside in the hospital. The clinical amphitheaters are small, furnished with wooden benches and desks, the latter a great convenience for the students in recording their observations. The training school for this hospital has seventy pupil nurses, who remain for four years. but receive a small salary after their period of approbation.

I found in this hospital, under the guidance of Dr. Alexander MacCormick, professor of surgery in the Sydney University, many rare and interesting cases of gastrointestinal surgery. Professor MacCormick has a very large service in this institution. The remaining members of the surgical staff are Messrs. Charles P. B. Clubbe and H. V. C. Hinder, both of them eminent and successful surgeons. The gynecologic practice is in the hands of Messrs. Foreman and Thring, wnose reputation extends far beyond the limits of Australia. The last annual report of this hospital shows some very remarkable statistics. Of 20 cases of hydatid of the liver operated on all recovered. In 30 cases of cholecystotomy operated on 26 recovered and 4 died. No death in 64 radical operations for hernia. In 16 cases of suprapubic and perineal cystotomy 2 died and 14 recovered. Sixty-five cases of simple appendectomy without 
a death; 27 cases of appendicitis with abscess formation with 1 death; 14 cases of appendicitis with rupture and peritonitis, 7 deaths and $\%$ recoveries. Three cases of pylorectomy without a death ; 33 abdominal hysterectomies with 3 deaths: 60 cases of salpingo-oopphorectomy for tubal disease with 2 deaths: 11 tubal gestations with no mortality. The operative records of this hospital make an excellent showing and would compare well with those of any hospital in America and Europe. The outdoor department is in a separate building and furnishes an enormous amount of material for the teaching of minor and casualty surgery.

MEDICAL PROFESSION.

The medical profession of Sydney is fully imbued with the spirit of modern medicine and surgery. Isolated as Australia is from the other continents, its medieal profession keeps pace with the newest and best in medicine and surgery. The country has no lack of the very best medical talent. The three medical schools furnish an abundant supply of youmg, enthusiastic and well-educated rloctors to fill the gaps made by death, retirement and removal, and for this reason the country has no need of melical men from without. The doetor's social standing in Australia is much superior to our own. His financial possibilities compare well with that of any other country. A fair average fee for a capital operation is $\$ 250$; maximum, $\$ 500$; consultation from $\$ 10$ to $\$ 25$, and visits average $\$ 2.50$. obstetric fee from $\$ 10$ to $\$ 25$. There are several men in Sydney whose annual income amounts to $\$ 30.000$. The country practitioners, of course, do not fare so well, but their expenses are so much less that at the end of the rear their bank account makes a fair showing. The relations between the members of the medical profession are cortial and the commercial element is not nearly as lampant as with ns. The requirements for entrance into the practice of merlicine are not at all stringent. A 
licensing board examines the eretentials of the applicant and, if the eamdidate is in possession of a diploma from a recognized medieal school. he is admitted without passing an examination. 'The local branch of the British Medical Association meets monthly and the sessions are usually well attended. The Australasian Medical Congress neets every three years and includes New Zealand.

Anelane, destralia, Angust 11, 1904.

THE MELBOURNE HOSPITALS.

Man, the masterpiece of ereation, the image of God, is subject to pain, disease and death wherever chance or circumstanee may have fixed his abode in the world, as

"There is no mortal whom pain and disease does not reach."-Cicero.

Primitive man has no, or at best only an imperfect, conception of the ways and means to protect himself against the disease-producing influences and he is powerless, or nearly so, when afflicted by aceident or disease. For ages eivilized man has endeavored to ascertain the rause of discases and to discover remedies for their prerention and successful treatment. In their primitive state the aborigines, living a natural life, are less exposer to injury and disease than civilized man living in luxury and intent on the accumulation of wealth or the gain of fame, for"

"Increased means and increased luxuries are the two civilizers of man."-Disraeli.

Civilization and the conditions and circumstances attending and following it have bred the most destructive diseases unknown to the primitive races. Firearms, conmerce. inerease of travel and the various industries incident to civilization are productive of accidents from which the natives in their original state were almost exempt. On the other hand. eivilization has alwars been concerned in wablishing effective sanitary measures and in devising rational and more suecessful treatment of injuries and disease. The principal functions of every intelligent and humane government consist in 
protecting its citizens, so far as possible, against disease and in making ample provisions for its indigent sick. Australia has met these two duties in a most creditable manner, as is so well shown by its well-organized effective Boards of Health, the many excellent hospitals and other numerous charitable institutions. The public hospitals are managed and supported nearly in the same manner as the hospitals in England. It is an inflexible rule that none of these hospitals should provide for prirate patients. They are supported by donations, life and annual subscribers. by government appropriations and pay patients. The medical men give their serrices gratuitously; the internes and nurses receive small salaries. The churches of different denominations, societies and individuals in all the states contribute liberally toward the building and maintenance of hospitals. Protestant denominational hospitals are unknown.

Melbonme is the capital of the state of Victoria. It is a beautiful city, built on the undulating hills on both sides of Yarra river, with a population of nearly half a million. Its streets are well paved, clean and well lighted with electricity, and its system of cable trams affords an easy and rapid means of reaching all parts of the city and almost every public institution. The many well-kept public parks. botanical and zoological gardens, museum and library furnish ample proof of the public spirit of its citizens. Nearly all of the business buildings and residences are either solid stone or brick structures. There is no private residence without its garden ornamented with subtropical trees, flowering shrubs and flowers. The Australian takes as much pride in his garden as he does in his house. and this applies equally to rich and poor, large residences and small houses. The city in its general aspects bears a close resemblance to Belfast, Ireland. The water supply and sewerage are now in a satisfactory condition and have contributed much in reducing the former frequency of typhoid. 
TIE MELBOULNTE HOSTPTII.

The Melbourne Hospital is the prineipal general hospital of the state. It is centrally located. It is a twostory sandstone building with a wide front and screral parilions, enclosing a square in the rear of the main building. Tiewed from withont it presents a somewhat stern, antique and rery massive appearance. One of these prvilions is devoted to diphtheria cases and stands isolated from the remaining buildings. The hospital can aceommodate 300 patients. It is in this hospital that the medical students of the University of Melhourne receive their clinical instruction. It has no grnecologic staff. all grnecologic cases being referred to the attending surgeons. The more legitimate specialties are well represented. The medical and surgical cases are under the care of four physicians and an equal number of surgeons. whose services are continuons throughout the year. 'The resident staff consists of a medical superintendent and eight internes. The latter are selected from the graduates of the university who have the highest standing: they remain for one year and serve in the different departments by being transferred every three months. The nursing is in charge of several sisters and 92 pupil nurses. The operating amphitheater is small but well lighted and on elerated seats guarded by iron bars provides standing room for the medical students and visitors; it contains all the essential equipments for surgical asepsis and necessary instrument-. I visited the hospital under the guidance of Mr. Fred D. Bird, one of the attending surgeons and profesior of surgery in the university. He showed me many eases of great surgical interest. among them sereral cases of intestinal and gastric surgery and the usual . number of appendix operations. I was shown a ease in which Mr. Bird had exeised a perforated astric ulcer of the small curvature of the stomach, four rears ago, near the prlorus, in a young woman. The patient 
made a satisfactory recovery, but returned recently to receive treatment for obseure digestive symptoms. In another case, a fourth operation for echinococcus of the omentum in a young woman had been successful a few days ago.

In all aseptic cases the wounds had healed or were healing by primary intention. All the wards were made comfortable and cheerful by fires in open grates and a liberal supply of flowers placed on the center tables and small bonquets for each bed, gifts of the Flower Mission. Cyanid gamze for dressing retains its reputation in this institution. Fine silk has almost entirely displaced the absorbable suture in the practice of Messrs. Bird and syme. In the absence of contraindications chloroform is used as the rontine anesthetic, administered with an Esmarch mask. The great work this hospital is doing for the sick of Melbourne and the state of Victoria can be seen from the last report, 1903-1904. 'The total number of patients treated was 22,925 , and of these 4,328 were received into the wards. The number of casnalties treated in the out-patients' department was 6.544 . In the infectious diseases department. 338 cases were treated, of which $16 ?$ were diphtheria. Although the antitorin treatment is in constant use. intubation was performed on 39 and tracheotomy on 14 , for the relief of urgent symptoms, and only two of the tracheotomies succeerled in saring life. 'This unfarorable experience in the tratment of this disease was due to the fact that many of the dhildren. when admitted. were in a condition beyond the eurative power of the specific tratment. One hundred and serenty-one cases of typhoid ferer were treated huring the year. with a mortality of 18. Puemonia appears to have been rery - virulent, as 63 out of 133 cases rlicd. a mortality of nearly 50 per cent. The surgical showing of this hospital is excellent. Exploratory lapapotomy was made 39 times without a death. Of 32 eases of hyrlatids of the liver operated on, 4 died; of 11 eases of abdominal hyda- 
tits, all recovered; of 15 cholecystotomies one died; of 102 cases of appendicitis sulpjected to operative treatment 15 died, and in 40 cases the disease was complicated by suppuration. Ovariotomy was performed 19 times without mortality. Of 10 eases of hysterectomy :3 died; 11 ases of tubal pregnaney with one deatli; 11 operations for pyosalpinx without a death; 99 operations for maliynant tumors. 99 were relieved, $1+$ not benefited and 6 tied; in 100 enses of radical operation for hernia, of which number $\% \%$ were inguinal, 2 died. Of $r$ cases of prostatectomy 5 were relieved and 2 thed. Two cases of perforatet typhoid nleer operated on dien, and of $y$ cases of perforated gastric nlcer operated on only one recovered. This hospital, the oldest and largest in the city, is always overcrowded and lacks many features of a modern institution, all of which should appeal strongly to the charitably disposed citizens and an appreciative generous goverument to provide it with ample means to earry out its hmmane intentions on a larger and more efficient scale in the future.

\section{RIDIGI, CURE FOR INGUINAL HERNIA.}

Australian surgeons, as a rule, prefer Bassini's methof in operating for the radical cure of ingninal hernia. Professor Bird is in favor of a small incision parallel with and at least one inch above Ponpart's ligament. He is careful not to injure the fibrous expansion of the suporficial fascia ant external oblique any more than is absolutely necssary to reach the hernial sac. Instead of nsing the knife freely, as is nsmally done, he makes liberal use of blunt dissection, thus separating instead of cutting resisting fibers. He never divides the external ring and insists that if we divide it, no suture, however deft, will make it nearly as strong as before; "we divide fibers whose integrity we can never replace." The incises the external ring only in yomg subjects to procure room to carry ont the necesary manipulations in the canal. He believes that the unnecessary division of the strong 
fibers of the external ring is responsible for many relapses. He is likewise cautious not to divide any of the muscular fibers of the internal oblique and cremasteric muscles, insisting that the integrity of all these structures should be respected. The infundibuliform fascia is torn through with a pair of dissecting forceps, and the sac, carefully isolated and separated from the cord. is then proceeded with, the isolation being commenced from above and behind. The sac must be cleared as far up as the deep epigastric artery. The sac is then tied with catgut at the point where it is continuous with the parietal peritoneum and excised below the ligature. He is of the opinion that when the operation is performed in this manner deep Bassini sutures are not only unnecessary, but actually harmful. Suturing of the inguinal canal after excision of the sac be only resorts to when the hernia is old and large and when the obliquity of the inguinal canal is much impaired. The suggestions made by Professor Bird are based on anatomic facts and should receive the earnest attention of surgeons.

\section{PROSTATECTOAY.}

This operation has found much favor in Australia. The suprapubic and perineal route have each their advoeates. Mr. G. A. Syme, lecturer on anatomy in Melbourne University and one of the surgeons to the Melbourne Hospital, performed his first prostatectomy in September, 189\%. He resorted to Frever's methodsuprapubic intravesical enucleation of the gland. Two vesical calculi were remored at the same time and the patient marle a speedy and perfect recovery. In the next case he found enueleation impossible and he had to excise the projecting middle lobe with scissors. In his fourth case the enucleated mass weighed seven ounces and had to be fragmented to permit its removal through the resical wound. In the fourth case previously operated on for enlarged 
prostate, he removed through the suprapublic route four phosphatic calculi and excised the projecting middlo lobe. A third operation became necessary, and at this time another stone was removed and the entire gland enucleated. All these patients reenvered with satisfactory functional results. $\mathrm{He}$ is a strong believer in the superiority of the suprapubic over the perineal route and quotes statisties from Melbourne Hospital to substantiate the eorrectness of his position. He advises operation in all cases in which the obstruetion is caused by the adenomatous form of prostatic enlargement.

\section{ALFRED HIOSPITAL.}

This hospital. somewhat remote from the center of the city, has a beantiful location and oceupies the middle of ample grounds made attractive by trees, shrubs and flowers. It was founded in 1874 and consists of two-story brick pavilions arranged around an open court. The wards are large, airy and well lighted and ventilated. The main operating room answers all mortern requirements and has a small amphitheater for students. who receive here the benefit of extra mural clinical teaching. Three physicians and three surgeons constitute the attending staff. The consulting staff is marde up of one physician and one surgeon. The surgeons attend to all gynecologic cases.

The surgeons on duty at the present time are $\mathrm{H}$. O'Hara, Esq., F.R.C.S., T. M., and L.K.Q.C. P. I.; John Cook, Esq.. M.R.C.S. Eng.: R. H. Russell, Eaq.., F.R.C.S. Eng. As in all Anstralian hospitals, the nutdoor department has separate attending staffs and anesthetists, electrician. dentist, masseurs, massenses, dispenser and pathologist. complete the list of regular hospital attendants. Three resident internes are appointed for two and a half years from the graduating class of the University of Melbourne, their merits being gauged by their class standing. The junior internes are paid $\$ 250$ a year. the senior internes $\$ 500$. The children's 
ward in this hospital is one of the finest $I$ have ever seen. The upper part of the walls are frescoed, the pictures representing fairy tales, and at the foot of each bed is suspended from an erect curved wire a small conical tin eup which visiting relatives, friends and the Flower Mission supply regularly with fresh cut flowers. I was shown here a number of cases of liver hydatids recently operated on. It is the experience of surgeons that these cysts seldom rupture into the stomach and that, as a rule, they do not give rise to adhesions. Hydatid of the kidney is very rare. This hospital has an enviable record in the surgical treatment of perforating typhoid uleer. During the last two years six cases were operated on and of these only one died. In about half of the eases this accident is initiated by a sudden fall of temperature. Chloroform is the anesthetic of ehoice. Silk, kangaroo tendon, catgut, silkworm-gut and horsehair are all in use, aceording to the indications presented by the wound under treatment. The government appropriation for this hospital amounts to from $\$ 15.000$ to $\$ 25,000$ a year and the subscriptions from $\$ 10$ to $\$ 45.000$. Patients who can pay are charged from 50 cents to $\$ \pi .50$ per week, the latter figure being the maximum. This is one of the few hospitals in Australia supplied with a steam-heating apparatus. The training school for female nurses connected with this hospital has 50 pupils who serve for three rears and have to pass two satisfactory and quite rigid examinations before they receive their certificate. In this connection it is worthy of notice that in each hospital the nurse's garl) differs in color, all shades of blue, and gray and black, with white caps of the strangest designs, distingnish the nursing statts of the different hospitals.

During the last year 1.910 patients were admitted to the wards and $4,7.50$ out-patients with 2.058 casualties were cared for in the outdoor department. It is noteworthy in looking up the records of the hospital in referenee to the religions envictions of the patients that 
out of $2,07 x$ cases only onc confesicel that he had no religion, and only one plareed his confictence in ('onfucius. Out of 1: ases of typhoid ferer treated in the hospital during the last year 11 died, and of 90 (ases of pneumonia 6 proved fatal. Aneurism appear. to be much more common than in our comtry, as this hospital received 8 cases Auring one year. Abdominal hysterectomy has a doleful record in this hospital, as in 10 eases only 2 were discharged cured, 1 relieverl, : remained in the hospital and 4 died.

MELBOURNE HOSPITAY FOK SICK CIILIIEX.

'The Melbourne Children's Hospital is an institution that reflects much credit on the state of Victoria and the city of Melboume. The hospital is beantifully located and consists of a number of two-story hrick pavilions. The wards are large, airy and flooded with an abundance of light. Flowers, palms and erergueen plants impart to all of them a cheerful appearance, which is greatly aecentuated by the presence of tidy, smiling muses. It receives sulstantial government appropriations and is well supported by roluntary contributions in the form of legacies. donations and subscriptions. It ean accommodate 100 children. The medical and sureical staff is marle up of ten members, with Charles S. Ryan, M.B. Ch. Edin., M.R. Melb., L.M. Dublin, at the head. Mr. Ryan is also at the head of the medieal department of the military forces of Victoria with the rank of colonel. The hospital has two internes and 45 nurses. who remain in training for three years. The convalescent. are sent to the convalescent home for children, Brighton. in charge of sister Danaher, a branch of this institution. I visited the hospital in company with Professor Bird, with Dr. W. H. Summons, a member of the attending staff for the outdoor department, as chaperon. The operating room is perfect and supplied with all modern improvements and appliances. We found here Dr. Mackay operating for hydatid of the liver in a boy 13 
years old, who had been aflicted with this disease for five years. The cyst, the size of a man's fist, occupied the under surface of the liver in the region of the suspensory ligament. The incision was made vertically, from the border of the costal arch downward. The cyst was incised, opening of cyst drawn into the abdominal incision with the index finger, contents emptied and margins of cut sutured to the abdominal wound. after which the lining membrane was grasped with a broad, blunt forceps and extracted with ease. Two drains and a small absorbent aseptic dressing finished the operation. I was somewhat surprised at the extent to which the Thomas splint is used here in the treatment of tubercular coxitis and spondylitis, as its usefulness can not be compared with the plaster-of-Paris fixation splint in the former and the Rauchfuss sling in the latter. During the last year the hospital cared for 1,302 sick children and the outdoor department had attendances amounting to the astonishing number of $6 \tilde{i},-$ 489. of which number 10,930 were new cases. Three cases of hydatid of the mesentery were operated on, 4 of the liver, 2 of the lung and 1 of the brain; all recovered. Of is cases of rheumatism 12 proved fatal from complications. One out of two cases of hemophilia died. Seventeen cases of cleft palate were operated on without a death. also 10 cases of congenital dislocation of the hip by the bloodless operation without mortality. In 27 cases of chorea 1 died of endocarditis. Of 33 cases of empyema, 6 died. Of 146 cases of pneumonia, 7 died, while the disease proved fatal 5 times in 24 cases of broncho-pneumonia, and 5 times in 32 cases of endopericarditis and endocarditis, and no fatality in 6 cases of pericarditis. Twenty-two cases of appendicitis were operated on, with 4 deaths, among them one perforation; and 6 radical operations for hernia. with 3 deaths. In 11 cases of intussusception. the operation failed to save life in 6 . Of 2 cases of cirrhosis of the liver, both dien. Of 50 cases of tuberculosis of spine and larger 
joints, 1 died. No mortality in 43 frictures of the limbs, and 1 death in 4 fractmes of the skull.

S'T. VINCENT'S HOSTITAL.

'This is the only denominational hospital in Melbourne. It is conducted by the Sisters of Charity, a religious order, with the mother house at Dublin, Ireland. The present hospital is a private residence reconstructed for hospital use. It can accommodate 30 patients. Two surgeons, Mr. G. A. Syme and Dr. William Moore, and two physicians constitute the attending staff. to which must be added the different specialists, four anesthetists. the pathologist and the members of the outdoor department. Last year the Sisters received a government appropriation of $\$ 3,500$. The Catholic cler@y are the most liberal subscribers. A small training school for nurses is connected with the hospital, in charge of the scren sisters. One interne answers for the resident staff. An elegant four-story brick building. with all modern improvements, and which will cost $\$ 150,000$, and which will accommodate 200 patients, is now in process of construction. The new building when completed will be the best hospital in Melbourne. Last year 10 cases of hydatid were operated on. all successful: 32 cases of appendicitis. with 2 deaths, in 8 the disease was complicated by suppuration: 25 cases of radical operation for hernia, without a death, and 6 cases of suprapubic cystotomy, with no mortality. The whole number of operations during the year amounted to 498 , of which number 490 were relieved and only 3 died, a mortality of 1.6 per cent., a record which can not be surpassed and which does great credit to the surgeons who performed the operations. I can not quit Melbourne without giving a brief description of

\section{A TRIP TO THE GIANT EUCALYPTUS TREES.}

On his arrival at Sydney the traveler's attention is attracter at once by two of the characteristic trees of 
the country. the wild fig tree and the cucalyptus tree. 'Two species of the former, the Ficus australis and the Ficus macrophylla, the Morton-Bay Fig-tree, both of them indigenous through a great part of East Australia, the grandest of Australian avenue trees. They resemble each other very closely in appearance; the latter, however, is a larger tree and has broader leaves. The stems are short. the crowns broad and the ronts wide-spreading. There is a dense foliage of erergreen leares, which are oblong, with a deep green shiny upper and a pale green lower surface. The fruit is in the. form of a miniature fig, with very small seeds, the farnite foor of the wild pigeon. These trees are the prineipal shade trees in this and other Australian cities. The encalyptus tree is the monarch of the Australian forests. It is found everywhere, on the coast. the plains, and invariably crowns every hill crest and all mountain peaks. It is an intolerant, jealous, selfish. anarchistic tree, its greatest virtue being its meonquerable patriotic sentiments. Diversity of climate and soil have succeeded in the course of thousands of rears to break up the original family into nearly 100 species. Baron ron Mueller has described $\% 2$. It is a strange tree. It never remores its green turban of pale green. long, narrow, pointed, aromatic leaves. but instead throws off its ragged garment of rough bark once a year in noder to exhibit its new, gay, grarish-white jurenile rless. I never lost sight of this tree during my 1,000 -mile railway journey through the coast distriets of Australia. The air everywhere was perfumed with the ethereal aromatic exhalations of this ubiquitous tree. I had heard much of the immense forests of giant eucalyptus trees of Australia, and was extremely anxious to satisfy my curinsity to see one of them. This decire was gratified Sunday, August \%. Accompanied hy Professor Bird, his son, and Prof. G. A. Syme, we left Melbourne by rail at 11 a. $\mathrm{m}$. and arrived at Heals- 
ville, 40 miles distant, two hours later. Healsville is at the foot of a range of mountains that rise to a height of from 2,500 to 3,000 feet above the level of the sea. The village is the terminal point of the railroad. 'The road passes through a prosperous agricultural and pasturage plain, from which the momntain ranges can he seen in the distance. 'The encalyptus tree at tains its larest size in the moist. fertile ravines and smmmits of the mountains, where the rainfall is most abundant.

A carriage awaited us at the depot, and we at once ascencled the excellent zigzag road which leads orer one of the mountain passes. From the very beginning we entered a forest of eucalyptus, with an almost impenetrable undergrowth of shrubs and bramble. Rablits shot across the road with the speed of lightning, and the little Australian quail sought, slowly and thoughtfully, shelter in the inaccessible jungle. Magpies and the laughing jackass (Australian kingfisher) watcher our progress and defied us in a language replete with mockery. It is a great treat to see a virgin forest of encalyptus trees. As we ascended the steep, tortuons incline the trees became larger and larger, until we reached the highest elevation, when we were face to face with the patriarchs who were born centuries ago and had nearly reached the limits of their lives. Here were trees 250 feet in height and 33 feet in circumference. These veterans had not forgotten their customary habits; old and decrepit, they were engaged in throwing off their old clothing that had served them for fully a year. They began the divestment of their dilapidated garment near the top of the evergreen crown, from where the rags were hanging down in streamers, swayed to and fro by the mountain breeze, and many of them were lving in disorder at the foot of the rejuvenating veteran monarchs of the forest. They were not premature in changing their clothing. The bare parts of their bodies and limbs were already protected by a hrand new coat and sleeves of a smooth silvery-white 
investment. The tree that lifted its head high above everything around it and reached the greatest dimensions was the Eucalyptus amagdalina, the giant gum tree. In some localities this tree attains a height of over 400 feet and a circumference of more than 60 feet. About the only other tree that is congenial to these anarchistic mountaineers is the fern tree. The pale green foliage and black, rough stem of the latter is in strong and pleasing contrast with the dark green crowns and white, smooth, bare trunks of the former. We found here three species of fern trees. the Alsophita australis, with a low, thick stem and a terminal scanty tuft of short cut leaves. the Diclisonia antartica and the Dicksonia davalloides, the high fern trees with a slender stem from 20 to 30 feet in height and an immense 1 mbrella at its top made of fronds of enormous length. The Dicksonia in some localities is known to reach a height of 60 feet. The blue gum tree (Eucalyptus globulus), grows in abundance in Victoria. It attains exceptionally a height of 300 feet. It grows with unparalleled rapidity and yields a tough wood admirably adapted for shipbuilding and other purposes for which a durable and strong material is required. Shipbuilders can get keels of this timber 120 feet long. It is from this tree that encalyptol and the varions encalyptus preparations are most profitably obtained. F. H. Faulding \& Co., Adelaide, are the principal manufacturers of the eucalyptus preparations used as antiseptics in internal and external medications. We found in this forest a great number of one of the most beautiful of the ornamental trees of Australia-the golden wattle (Acacia pycnantha), opening its blossoms of golden yellow in the form of long, drooping tassels. When in full bloom the evergreen leaves are almost obscured by this golden drapery. The tree attains a maximum height of about 30 feet; its long, slender trunk is branchless almost to its rery top, and when, with the carliest indications of approaching spring, it decorates 
itself with a crown of gold, it presents a lovely sight, even in the shadow of the giants of the encalyptus race. The sight of a eucalyptus forest intemingled with the fern trees and the golden wattles and sprinkled with the fresh and brilliant early spring flowers is inspiring and leaves a pleasant impression which time can never erase from memory.

Fremantle, Australia, August. 15.

THE ADELAIDE HOSPITATS.

Adelaide is the capital of the state of Southern Ans. tralia. A railroad seven miles long connects it with the harbor, Port Adelaide. It is the intellectual as well as the business center of the state. The city is located in the midst of an extensive fertile plain, with a range of tree-clad hills in the distance and the ocean in the opposite direction. Its streets are wide, well laid out, well paved and clean, but the electric lighting is conducted on an economic scale. Present population, 60.000 . The bobtail horse trams remind one of the size of the city, while the substantial sandstone buildings in its main streets would do credit to any of our large cities. Australian cities have. fortunately, no need of sky scrapers, which disfigure our large cities: buildings more than three stories high are the exception, and time-saving. muscle-weakening and lung-crippling elevators have as yet but a limited sphere of questionable usefulness. Adelaide has a young, prosperous unirersity, splendid botanic and zoologic gardens, public library, art gallery, museum and a number of attractive parks. It is an ideal university city, where students are given all conceivable opportunities to enrich their minds with object lessons in all the arts and sciences, and where they are free from the many temptations which lurk in such abundance in all of the large cities. Medical students are given here very thorough didactic teaching, and the clinical material is large enough for practical instruction in medicine, surgery and the dif- 
ferent specialties. The hospitals of Adelaide receive patients from all parts of the state and furnish the medical department of the mniversity with an abundance of material, which is ntilized by the teachers to greatest arlvantage for berlside and amphitheater instruction. It is somewhat remarkable that none of the general hospitals of Anstralia makes any provision for maternity cases, but all medical schools hare a large out-door obstetric department. where the students receive practical instruction at the bedside of the poor in this most imfortant branch of the healing art. One of the rigid requirements for graduation in all of the medical schools is to the effect that the candidate must present eridence that he has attenderl a speeified number of confinement cases.

TIIE ADELAIDE IIOSPITAL.

The Adelaide Hospital is the largest and only public general hospital in the eity and its medical affairs are controlled by the clinieal staff of the university. It was founded 50 years ago and can accommodate 240 patients. The main building, of sandstone with brick corners, is two stories high. It is situated some distance back from the street in the rear of an open square which has been converted into a beautiful little park, with well lairl ont gravel drives and walks and shaded with a rariety of trees and ormamented with shrubbery and Howers. 'The remaining two ineluding sides of the park are accupied by one-story buildings. most of them of recent construction. The operating theater now in use is: antique and the surgeons are anxiously awaiting the opening of the new one. which is nearing completion and which has been well planned and will represent the most modern improvements in this, the most important part of any hospital. The wards in the old building are somewhat gloomy and not sufficiently lighted. The electric light has not as yet been introduced, and the scanty gas jets at night can be no im- 


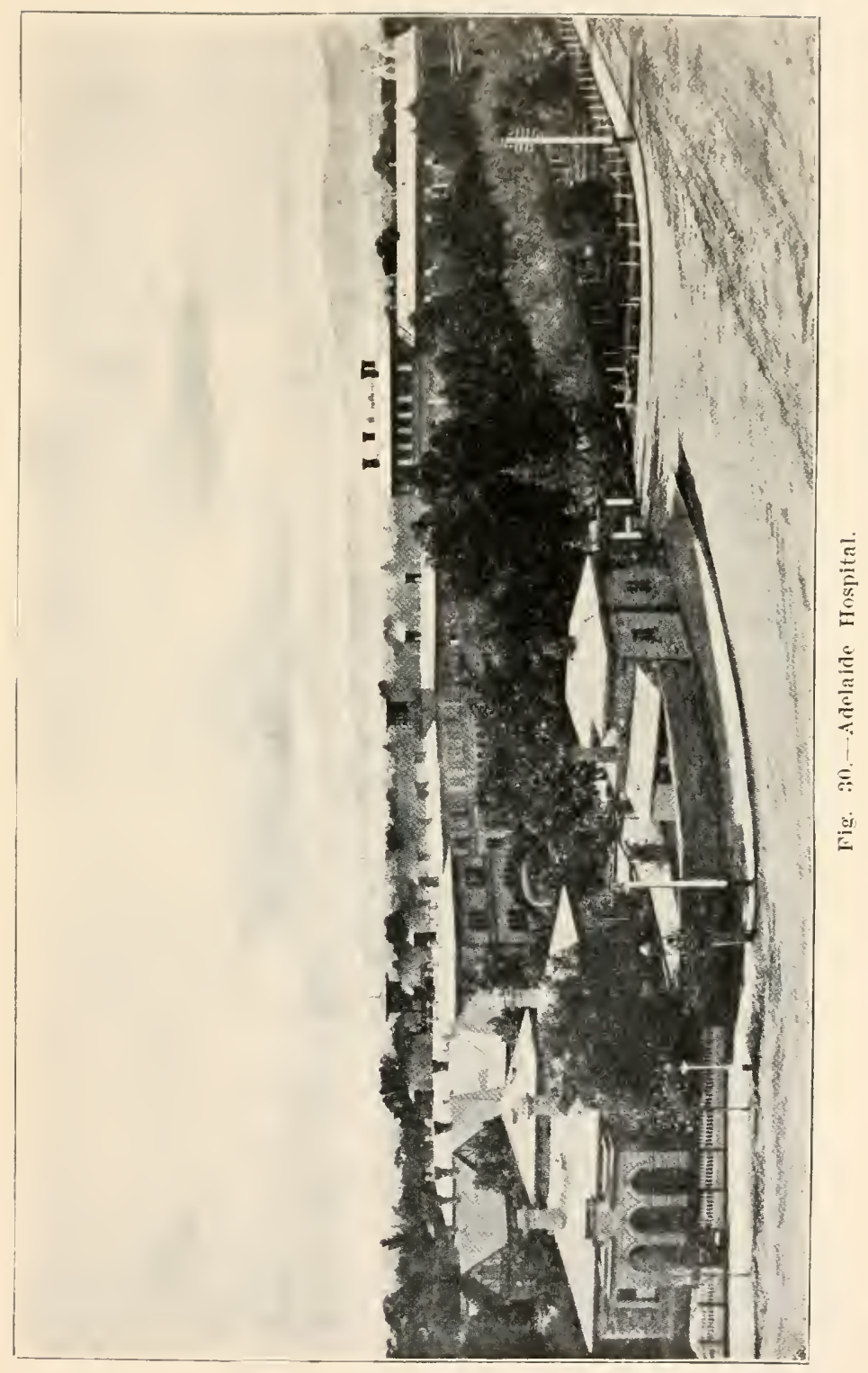



provement on the defective darlight. Heat is supplied by open coal fires. In one of the surgical wards the grates occupy the base of a beautifully frescoed square column, which contributes much to the cheerfulness of the otherwise somber room. As in all Iustralian hospitals, a profusion of flowers imparts to the sick rooms a homelike and cheerful appearance. Owing to a somewhat miserly government aid, it is interesting to know the sources from which the additional funds are obtained to carry on the work of this deserving cluarity. For the purpose of stimulating the spirit of charity among the people the contributors are given certain privileges, a practice which it would be well for some of our hospitals to imitate. On this subject I will quote from the last annual report of the hospital:

"1. Every contributor of $£ 2$ annually shall have the privilege of recommending one indoor patient in the year ; of $£ 5$ annually. three indoor patients in the year; of $£ 10$ annually, the privilege of having always one patient in the hospital.

"ฉ. Contributors of $£ 2$ annually shall also have the privilege of recommending six ont-door patients for relief from the dispensary; contributors of $£ 5$, twelre patients. contributors of $\mathfrak{£} 10$, fifteen patients. It is to be distinctly understood that these recommendations are only to be issued by the contributors to persons who can not pay for medical treatment elsewhere.

"3. Life contributors to have the same privilege in proportion. Their donations being estimated as annual contribution of one-tenth." The restriction placed on the issuing of recommendations on these terms is repeated once more in paragraph 5, regulating the admission of patients: "It is to be distinctly understood that these recommendations are only to be given to persons who, on account of their porerty. are proper subjects for hospital treatment." In paragraph 6 provision is made to exclude charity patients who are able 
to pay for medical service: "Applicants for admission to the hospital shall, unless possessed of means sufficient to pay for medical adrice, make a declaration, on a form printed for that purpose, to the effect that they are mable to pay for medical advice, and stating whether they are entitled to medical attendance from any benefit society or lodge."

That these declarations are not always in accord with facts became evident to me in visiting the different hospitals. Many patients find their way into the hospitals who are abundantly able to pay the physicians a fair remuneration for their services. The abuse of charity is practiced here as well as elsewhere on a large scale. The people are fully aware of the fact that they can secure the very best medical and surgical talent in hospitals connected with medical schools, and are willing to declare and sign almost anything to avail themselves of the gratuitous services of the attending staff. The Adelaide Hospital cares for many such impostors. Adelaide and the surrounding agricultural and pastoral country are in a prosperous condition, and many who seek the shelter of this hospital rob it and the medical profession ammully of a large amount of money which they have well earned and to which they are justly entitled. Such abuse of charity is difficult to remerly. more especially in the case of hospitals connected with merical schools.

Drs. E. C. Stirling and Archibald Watson are the consulting physicians and surgeons. Four physicians constitute the medical and three surgeons the surgical staff. The present surgical staff consists of Leonard II. Bickle. M.R.C.S. Eng., L.R.C.P. London, F.R.C.S. Erlin.; William Anstey Giles, M.B., Ch.M. Edin.; Benjamin Ponlton, M.D. Melb., M.R.C.S. Eng. Two gynecologists, two ophthalmologists, one surgeon for the ear and throat, a bacteriologist, a dentist and two pathologists complete the list of medical officers with the axception of the resident medical smperintendent. Mr. 
F. J. Chatlee, six assistants and five internes. The internes ale selected from the graduating class of the university on their college standing. One of these internes is a woman, who assists Mr. Giles in his surgrieal work. The women internes in this hospital have made an excellent record. 'The internes, as in all Iustralian hospitals, receive a small salary and serve for one year. 'The training school for female nurses conneeted with the hospital has 50 pupils, several sisters and a matron. 'The nurses remain in training for three rears and receive annually from $\$ 100$ to $\$ 200$, according to the length of time of their service. The new laboratory is capacious, well lighted and is in charge of a craduate nurse, who does all the mechanical work and prepares the culture mediums. Patients suffering from tuberculosis of the lungs do not remain in the hospital for any length of time. as they are sent from here to a sanatorium in the mountains seven miles from Adelaide, built specially for this purpose and managed by the same administration. Other infective discases are not admitted to the hospital. Turpentine and biniodid of mereury solution are favorite antiseptics with many Australian surgeons in hand disinfection. Catgut and kangaroo tendon have been largely displaced by fine silk. On the whole, chloroform is nsed more frequently than ether as an anesthetic. Cyanir gauze as an inner dressing for wounds remains popular. I had the pleasure of seeing considerable of the surgical work of two of the clinical professors of surgery in the miversity, Dr. Poulton and Mrr. Giles. The former I found operating on a case of prostatic lypertrophy in a man 6.5 years of age. who had suffered from the obstruction for several years. The usual long suprapubic vertical ineision was made, the peritoneal reflection pushed upward, and the bladder incised on the point of a sound previomsly introduced into the bladder and held in position by an assistant. Repeated efforts to enucleate the gland after incision of the mucosa failed. 
It was one of those cases in which the enlargement was not dne to the growth of adenomata, but to a hypertrophy of the gland itself, hence the impossibility of removing it by intravesical enucleation. It is in such cases that the most experienced surgeon will fail in removing the obstruction by the suprapubie route. Suprapubic drainage of the bladder was established by the use of rubber tubing fixed in the lower angle of the wound with sutures and the balance of the wound carefully closed. The next operation was performed by one of his assistants. The patient was a man 72 years old, the subject of a tumor nearly the size of a fetal head occupying the right parotid and submaxillary regions. There could be no question as to the malignant nature of the tumor. as it had reached its present dimensions since last Christmas. As the labial branch of the facial nerve had lost its functions it was suspected that the tumor had its starting point in the parotid gland. The opcration was a very difficult one, but was executed with care and precision. The operator from time to time availed himself of anatomic information furnished by Professor Watson, who stood by and watched every step with his eagle eyes. The lymphatic glands were not inrolved and the operation demonstrated that the tumor had its origin in the submaxillary salivary gland and was undoubtedly a sarcoma. One of the most interesting cases in Dr. Poulton's wards was a man in middle life who had recently been operated on for an obscure swelling in the region of the gall bladder and extending to the right lumbar region. Positive diagnosis could not be made, although it was suspected that it was conneeted either with the gall bladder or right kidney. It was first noticed a year ago. Ureteral catheterization in the male, as a diagnostic aid, has so far not been practiced by any of the Australian surgeons so far as I was able to ascertain. 'The French separator (Luys), on the other hand, is frequently made use of. In this case a vertical incision was made from 
the eighth costal cartilage downward. On cutting through the abdominal wall the retroperitoneal location of what now could be recognized as a cyst was ascertained without any diffeulty, the ascending colon being displaced inward. Marsupialization was resorted to. This term is often employed by Australian surgeons to indicate the radical operation for echinococcus crsts and the treatment of other cysts by incision and drainage. This word was coined here and owes its origin to the many species of marsupial animals which inhabit Australia, animals which give birth to their offspring in the embryonic state and mature them in a pouch on the ventral side of the body, where the young have easy-access to the milk-supplying breasts. After opening and stitching the sac to the abdomnial incision, the dermoid character of the cyst was demonstrated by the escape of a large quantity of hair and sebaceons material. The patient was doing well, relieved of all subjective symptoms, and only a small quantity of a mucoid fluid was discharged daily throngh the drain which remained in the cyst. Such cases in this particnlar location are extremely rare, and it is to be hoped that a full report of the case will soon find its way into the current medical literature. The safety of the operation was enhanced in this case by previous firm adhesions between the two layers of the peritonemm, so that the marsupialization was practically extraperitoneal. It has been obscrved in this, as well as in other 10:pitals of Anstralia, that the aborigines are more frequently afllicted with hydatids than the whites, as they are more exposed to infection, living with numerous dogs, and often obtaining their water supply from stagnant pools. Dr. Altman, of Bright, has operated on many natives aflicted with this disease. All surgeons consider the natives gond subjects for nareosis and capital operations. They are. howerer, very prone to homesickness and shorten their stay eren in the best 
hospitals as much as their condition will permit. The surgical wards of the hospital contain 28 beds, and the new parilions are perfect in construction and appliances. The upper part of the walls are artistically freseoed, the pictures pleasing and well selected for the purpose for which they have been intended.

The next day. July 10, I visited the hospital again, this time with Mr. Giles, dean of the medical faculty and professor of clinical surgery, who had in his wards many very instructive cases. One case was of special interest to me, and had misled the surgeon, and would have misled anyone else, in making a correct anteoperation diagnosis. The history of the case pointed to appendicitis. The operation revealed a retrocecal subperitoneal suppurating hydatid of the right iliae fossa. The operation yielded the expected relief, suppuration has almost ceased, and the patient will soon be discharged, restored to perfect health. Within a very few weeks Mr. Giles had operated on three cases of undescended testicle, complicated by hernia. In all the results were excellent. Mr. Giles has the reputation of being one of the most conservative and suecessful surgeons of Southern Australia, and his clinical teaching is highly appreciated by his attentive classes. Appendicitis appears to be unusually prevalent in Southern Anstralia, as I was shown many cases recently operated on in the wards of both Dr. Poulton and Mr. Giles, and I have no reason to believe that either of these surgeons would resort to the use of the knife unless the indications were clear.

The great prevalence of hydatid in Adelaide and surrounding country is well shown by the records of this hospital. Last year 34 eases were operated on. of which number 3 dier. Pneumonia appears to have been very virulent, as of 69 cases, 43 were cured, \pm relieved, and 22 died. Of 30 appendicitis operations. 26 were eured and 4 died; 2 deaths in 19 cases of ectopic pregnancy: 
29 (ases of pyosalpinx, with 21 cures. 1 relieved, 4 unrelieved, and is deathe; 16 cates of mrofibromata, l: cured, : mrelieved, and 2 died; 5 gastro-enterostomies, with 2 deaths; $\$ 1$ radieal operations for inguinal and femoral hernia, without mortality : 10 (ases of strangulated herna. with 4 deaths; o cases of lithotrity. with 1 death : 4 eates of prostatectomy, witl :3 cured and 1 relicved: 2? hrsterectomies. 21 cured, 1 pelierest and is died: 20 aceisons of variense reins, withont mortality.

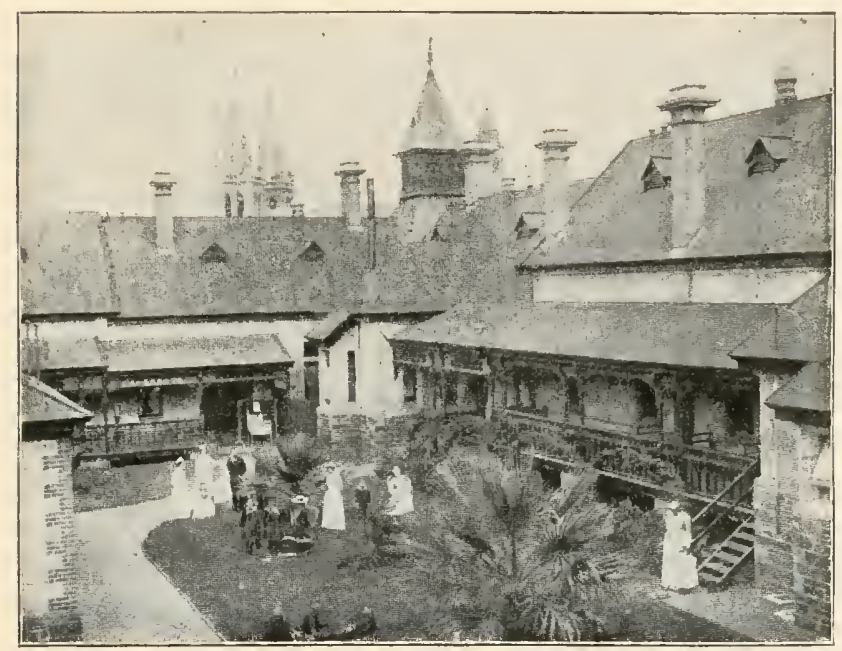

lig. :31.-View on tile grounds: Adelaide I'hildren's Ilnspital.

\section{ADELAIDE CHILDREX'S HOSPITAL.}

The foundation stone for this excellent institution for the eare of sick elildren was laid June 20. 18\%s, for what is now known as the Way Building, and fourteen months later the first patient was admitter. The Way Building and a number of one-story pavilions since erected enclose an open square where the little patients can enjoy the sunshine and outdoor air and find ample room among the shade trees for their childish amusements. The hospital is located on a high 
ridge, from where a beautiful view can be obtained of the eity and the distant mountain ranges (Fig. 29). It has accommodations for 80 patients. All the buildings are of stone, and the wards are well lighted and cheerful. The diphtheria ward is never empty. One of the trained nurses administers the antitoxin under the direction of the attending physicians. The same nurse also has charge of the laboratory. The visiting medical officers are: W. M. Campbell, L.R.C.P., Edin.; Alfred E. Wigg, M.D.; Brnx.; Alfred Lendon, M.D.. London; Harry Swift, B.A., M.D., Camb.; A. M. Morgan, M.B., B.S., Ad.; R. Brumritt, M.R.C.S. Two consulting medical officers, two consulting pathologists, and one oculist, two dentists, one aurist. seven anesthetists, one pathologist. one bacteriologist, one radiographer, one sanitary adviser, one registrar and one interne complete the long list of medical men who serve this institution. One matron and a staff of six sisters supervise the nursing and have charge of the training sehool, which has at present an attendance of 50 pupil nurses. The hospital is kept scrupulously clean, and the little patients receive the benefits of nursing of the highest order and the very best medical and surgical service. Electric lighting, complete equipments and appliances for diagnosis and all kinds of surgical work add much to the efficiency of the institution. Medical students are admitted to the clinies, and several members of the attending staff are clinical professors of the university. This hospital is kept supplied throughont the entire year with a wealth of flowers.

The eitizens of Adelaide take great interest in this hospital, and their liberal contributions enables the administration to carry out its humane intentions in the most satisfactory manner. I visited the hospital in company with Dr. Lendon, professor of obstetrics and diseases of children, who is familiar with all the details of its construction and management, and is one of the most influential members of its medical 
staff. During the last year $\% 04$ new patients were admitted. One hmudred and two operations were performed on indoor patients and 364 on out-patients. Chloroform alone was used as an anesthetic 50 times; ether. 5s; gas, 4; chloroform, followed by ether, 353 ; gas, followed by ether. 1. Appendicitis operation, only 1, and this patient died. Tuberculosis of the hip joint figures conspicuously in the list of surgical cases. Of 25 cases, only 2 were subjected to operative treatment, showing conclusively the conservatism which is observed in this hospital in the treatment of joint tuberculosis. Of $\mathrm{is}$ cases of diphtheria, the discasc proved fatal in 3. Fifty cases of typhoid fever were treated withont a death, certainly a remarkable record. and $2 \%$ cases of pneumonia, with only 4 deaths.

\section{GALISTONE IN ELEPHANTS.}

During the last year three Indian elephants have died in the zoologic gardens of Australia, one in Melbourne, one in Queensland, and the last one in Adelaide. When I risited the museum of the university with Professor Watson the taxidermists were engaged in mounting the last victim. This elephant was of enormous size. He had been an inmate of the Adelaide zoologic garden for a long time, and was 30 years old. He was sick only a short time, and the postmortern. conducted by Professor Watson, revealed as the immediate cause of death an enormous abscess in the center of the liver, and in this abscess was found a gallstone that weighed 25 pounds. As the elephant has no gall bladder, this stone must have formed in one of the hepatic ducts. This rare and valuable specimen disappeared in a somewhat mysterious way before it could be taken to the museum, and it was ascertained later that it was purchased from the pilferous possessor by a. Chinaman, who paid $\$ 10$ for it and considered it a great bargain, as he expected to realize a fortune from it by converting it into a cure-all medicine for his sick 
compatriots. The Melbourne elephant on postmortem was found to have died from the same disease. but the calculus was much larger, weighing more than 100 pounds. It is not definitely known. but it is surmised that the Queensland elephant met with a similar fate. It seems that all large animals from tropic regions, when brought into confinement, are subject to inflammatory affections of the bile ducts and subseruent gallstone formation. As elephants even in Australia command a price of $\$ 2,000$, what inducement there would have been to perform on these giant patients a lifesaving hepatotomy!

POSTMOLTEM ON A ZEPRA.

One erening. in visiting the zoologie garden in Arlelaide in company with Professor Watson and the superintendent of the garden, a fine-looking. slick, well-mourished zchra came up close to the fence and seemed to enjoy my patting her forehead and well-romuled neck. The animal appeared to be in perfect health. It had heen in the garden for twelve years and was old when it was brought there. The next morning I was informed by Professor Watson that the animal had died ruring the night. In the afternoon $I$ attended the postmortem. which was made under the direction of Professor Watson. The abdomen was enormously distenderl. which seemed to indicate that the sudden death was lue either to intestinal perforation or acute intestinal obstruction. On opening the abdomen the giant cecum. ascending and descending colon were found distended to their maximum limits. Large isolated sections of the liver were the seat of great dilatation of the bile dnets. many of them sacculated, and on slitting them open. wre seen to eontain a thick, turbid mueus. the inflammatory acemmulation of a chronic cholangitis. Numerons ascarides lumbricoides of prodigions size were found in the stomach. well filled with the remains of the last erening meal. The upper part of the lumen 
of the small intestines was almost entircly occluded by wriggling masses of the same parasite, and they were also numerous throughout the large intestine. The transverse colon was of normal size, cceum, ascending and descending colon impacted with dry fecal matter alive with worms. It is evident that the immediate cause of death was the result of mechanical obstruction, complicated, perhaps, by toxemia arising from the rapid decomposition of the impacted material. These parasites were undonbtedly likewise, at least indirectly. responsible for the chronic inflammation of the bile ducts, as this affection was not diffuse, but limited to circumscribed parts of the liver.

\section{PRIVATE HOSPITALS IN AUSTRALIA.}

As the general hospitals of Australia make no provision for private patients, the surgeons are under the necessity to fill this gap by private hospitals in order to accommodate the patients who are able and willing to pay them for their scrvices. All surgeons with a large private practice either own or patronize a private hospital. Many of these little hospitals are operated by trained nurses. Several nurses combine, rent a private residence in a desirable locality, convert it into a hospital and throw its doors wide open to medical men who wish to patronize them. I was informed that the nurses who risk their time and money in such cnterprizes usually make them a success financially. Surgeons with means. however, prefer, as a rule. to build, own and manage their own hospital.

\section{TERRACE HOSPITAL.}

One of the neatest and most attractive private hospitals I ever saw is the property of Professor MacCormick, of Sydney. As its name implies. it is in a terraced tract of land, three acres in extent, which is bisected by a deep ravine, shaded by magnificent trees. The hospital, occupying the highest point of the romantic little 
park, is a two-story cottage brick building, with a grayish-white, rough coat of cement and a red tile roof. The finishing of the interior, the arrangement of rooms and wards, the heating, the ventilation, the operating room equipments and appliances are as complete as money and skill could make them. The building alone cost $\$ 80,000$. It can accommodate 40 beds. Ten graduate, salaried female nurses take care of the patients. The charge for board and nursing ranges between $\$ 15$ and $\$ 35$ per week. 'The large practice of Professor MacCormick fills the rooms and wards thronghout the year, and the hospital is prospering financially. One of the redeeming features of these private undertakings is the fact that they do not undertake to educate female nurses for the purpose of cutting down the running expenses, as is done only too frequently by similar institutions in our country.

\section{CLARETON HOSPITAL.}

This is a new four-story brick building, erected and owned by Professor Bird of Melbourne. It is situated in one of the finest streets, almost opposite the House of Parliament, and faces a picturesque park. The exterior of the building is pleasing in design and its interior is the best proof that the plans were well made to meet the requirements of a modern hospital. The cheery operating room is flooded with sunlight during the day and lighted by electric lamps at night, and the conveniences and appliances for asepsis are absolutely perfect. The upper part of the building contains the living rooms of the family, to which access is obtained by an elevator. 'The eight graduate nurses employed to take care of the 20 patients, the present capacity of the hospital, are well paid. and the two matrons receive $\$ 500$ each per year.

On Board S. S. Cimxa, Aug. 24, 1904. 
The number and character of the educational institutions of a country furnish the most reliable gauge with which to estimate the degree of intelligence of its people and the virtues of its government. Measured by this scale, young Australia compares well with America and the eomntries of the world. New countries, like new cities, have the great advantage of profiting by the experience of the past, placing them in a position to select what has been found most useful and practical and to eliminate what has been proved objectionable by the test of experience. The educational institutions of the old world and some of our own have been undergoing constant changes in the construction of buildings and methods of teaching, in order to keep pace with the rapid strides of progress and spirit of investigation and original research which characterize the present age. Scrutinized in the light of the beginning of the twentieth century, many of the famous, venerable, moss-cov' ered universities of the old as well as the new world appear like a patched garment when contrasted with the new, vigorous institutions of learning founded, organized and managed in accordance with the most recent requirements. Viewed from an educational standpoint, Australia has reason to take pride in what she has accomplished. The government of this country has been liberal in responding to the edueational needs of its slowly growing and now almost stationary population. Its public schools are within easy reach of every child, not only in its cities and villages, but wherever a small settlement is found in the mountain forests and arid plains. It has its grammar and high schools, colleges and universities, which meet all the necessities of a 
higher and professional education. It is a great mistake for any young Australian man or woman to leare their native soil in search of better opportunities to qualify themselves for any position in life, as the choicest and best lies at their very door. An Oxford or Cambridge degree will be of no more use to a professional man or woman in Australia or anywhere else than a degree from any of the three universities of the island continent, as the requirements for graduation of the latter are equally, if not more, stringent than of the former. This southwestern part of the world is fully aware of what is going on in the way of scientific progress and has already to some extent contributed its share to the common fund of knowledge, and is now in a position to become a more liberal contributor. We as physicians are more especially interested in the advantages offered by the Australian universities for its medical students. It is in this branch of university education that the greatest changes in the methods of teaching have been witnessed during the last quarter of a century. In writing this communication I have made liberal use of two addresses delivered by Prof. T. P. A. Stuart, the distinguished physiologist of the Sydney University ("A Review of University Life in Australia, Etc.." and "The Majority of the Medical School," the latter on the oceasion of the University of Sydney celebrations), and the last calendars of the three universities. The three Australian universities are located at Sydney, Melbourne and Adelaide, and were founded in the order in which these names appear. Each university has its own medical department. Fortunately for the new country and its medieal profession. private medical schools are out of the question. The requirements for entrance and graduation are about the same in all of the three schools and I quote here from the last catalogue of the University of Adclaide:

"No person shall be permitted to commenee the medical course until he shall have completed his sixteenth 
year and have produeed evidence of the fact to the satisfaction of the council. Before entering on the medical conrse the intending student must satisfy the examiners at the senior public examinations in the following subjects: 1, English literature and English history and geography; 2, Latin; 3, arithmetic and algebra; 4, geometry. $\tilde{3}$, one of the following-a. Greek; b, French ; c, German."

The medical course is five years. The examinations are held annually in November and supplementary examinations may be held, should oceasion arisc, in March. The students are not pestered with so many examinations as in some of on medical colleges and their time is spent in stearly, minterrupted work instead of onefourth of it being spent in eramming for the frequent examinations, as is the case with some of our schools.

The first examination inclndes: 1. Elementary anatomy and dissection; 2. elementary hiologr. theoretical and practical; 3, inorganic chemistry, theoretical and practical; 4, elenents of physics.

The second includes: 1. Anatomy, general and descriptive, with dissections; 2, pluysiology, including practical physiology, histology and physiologic chemiztry; 3, organic chemistry, theoretical and practical. with special reference to physiology and medicine; the chemistry of poisons, organic and inorganic, with special reference to their detection.

The third includes: 1, Principles and practice of medicine; 2, principles and practice of surgery; 3, regional and surgical anatomy; 4, materia medica.

The fourth includes: 1, Principles and practice of medicine, including clinical medicine; 2 , principles and practice of surgery, including surgical anatomy and clinical surgery; 3 , obstetries; 4 , forensic medicine, including insanity; 5. pathology.

The fifth and last includes: 1, Medicine, all branches; 2, surgery, all branches, inclnding anatomy and operative surgery; 3 , gynecology ; 4, ophthalmology; 5 , otology; 6 , elements of hygiene; $\%$, therapentics. 
It seems to me that the order of subjects in these examinations is cxcellent, leading the students from the elementary branches up a gradual incline to the most complicated practical subjects. Anatomy is taught in England better and more thoroughly than in any other country. The English surgeon is invariably a good anatomist. The Australian schools, conducted as they are largely by men who obtained their education in the United Kingdom, place the same stress on this, the most important of all the primary branches, and when their students graduate they know their anatomy. No time is spent in making skeletons of clay. Gray's Anatomy and Heath's Disscetor are their text-books and the cadarer their object lesson. Professor Matson. of the Adelaide University, has little confidence in lectures as a means of teaching anatomy, and spends most of his time in the dissecting room with his students, superrising. demonstrating and directing their work. Some of the dissections I examined were sufficient proof of the students' interest and diligence in acquiring their knowledge of anatomy and the efficieney of the methods of teaching employed.

The only fault I could find with the methods of teaching employed in the Australian medical schools is that too much weight is still given to didactic lectures and too little attention is paid to recitation courses. There are, howerer, indications that gradual changes will soon reverse this order of things. The attendance at the medical schools is necessarily small, the teaching force, on the other hand, in each school is large, conditions most farorable for systematic, theoretic teaching by the use of reliable text-books, recitations, remarks and demonstrations. Each of the three medical schools has the practical control orer a hospital of 200 and more beds, where the main clinical teaching is done. In Sydney it is the Royal Prince Alhert Hospital; in Melbourne, the Melbourne Hospital, and in Adelaide, the Adelaide Iospital. In all of these cities the students 
have also access to a children's and other hospitals, the former always directly or indirectly connected with the merlical school, the latter being available for extrit mural clinical teaching. Not much wejght is placed. howerer, on the importance or value of extra mural teaching in any of the schools. On the other hand, the greatest attention is giren to laboratory work, and all of the schools have excellent laboratories with all modern equipments and appliances. To other medical schools in the world can offer better inducements for their graduates to obtain an interneship in a hospital than those of Australia. Thus, of the 218 graduates of the Sydney University no Iess than $18 \pm$ held office as resident medical officers in some hospital, and growing hospital facilities will only increase the number of internes in the future. The fees for the whole course of five rears, including fees charged for examination, are about $\$ 5 \% 5$.

The universities confer three medical degreesBachelor of Medicine, Bachelor of Surgery and Doctor of Medicine. To obtain the last degree a Bachelor of Medicine or Surgery makes application one or two years after graduation, writes a thesis or passes another examination and, if satisfactory, receives the degree of M.D. As this degree is more honorary than useful and the obtaining of it involves another and not inconsiderable expense, most of the practitioners enter on their life work withont applying for it. Many physicians and surgeons prefer the plain title of Mr. to Doctor. All the professors receive a salary of from $\$ \$ 00$ to $\$ 1,500$ a year: in one or two of the mniversities they receive a pension of $\$ 2,000$ a year on retirement after 20 years' service.

SYDNEY UNIVERSITS AND MIEDICAL SCHOOL.

The Sydney University commeneed its first matrienlation on Oct. 4, $185 \%$. Its conrses of lectures were at first restricted to those required for the Arts degree; 
the medical school and the school of engineering were opened in 1883, and the law school was opened in 1890. (Figure 26). The teaching staff of the university has gradually increased from 3 professors and 2 lecturers in 1854 to 14 professors and 34 lecturers in 1899 , having under their care 519 students. The university owes a great deal to private benefactions. The total sum from this source at the close of 1899 was over $\$ 2,000,000$.

The university building is a magnificent solid stone structure in Gothic style, ocenpying the summit of a high hill and surrounded by 132 acres of land. The Prince Alfred Itospital is located on the same grounds. A large, fine brick building for the library is now in process of construction. The present chancellor of the university is Sir Normand MacLaurin, a distinguished Sydney practitioner of medicine. I will always remember with pleasure and gratitude the hours I spent with the chancellor in visiting the university, inspecting its great hall, library, rich musenun and the medical school. Sir Normand has shown great tact and executive ability in the management of this young but rigorous institution, but has not lost his interest in medicine and he takes a just pride in the medieal school on which he showers his fostering care. The university has now an attendance of about 700 . of whom 250 are medical students. Professor Stuart is the heart and soul of the medical school and its present tean. :

The medical school is the gem among all the university buildings. (Fig. 32.) It owes its origin largely to the inclefatigable efforts of Dr. H. G. Douglass. Sir Charles Nicholson, Mr. Wentworth. Prof. .John Smith and Dr. Richard Greenup. The first medical school commenced its work in 1883 in a four-room cottage. (See Figure $2 \%$.) The palatial new eollege building was completed in 1890 at a cost of $\$ 400.000$, one of the finest buildings of its kind in the world. It is a massive stone building in imitation of the university building, with tile floors througlout and inner finishing seldom seen 


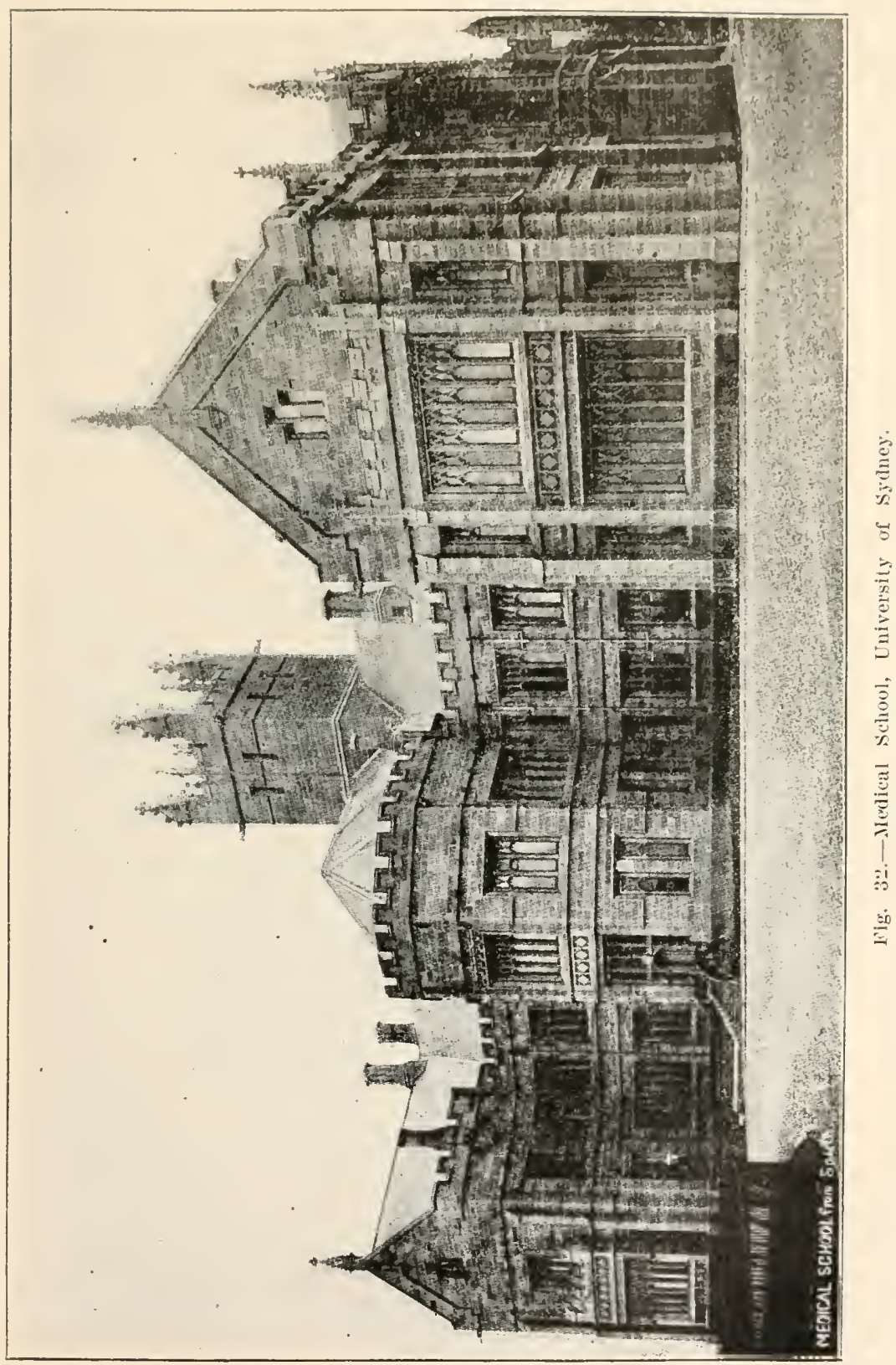



in a medical college. Statmary and stained glass windows make one forget one is in a medical college. One imagines he is in a cathedral or a palace. 'The stained glass windows do not immortalize saints, but the men in our profession, whose work has made merlicine and surgery what they are to-day. The inner architecture corresponds with the beanty of its external appearance. The lecture rooms and laboratories leave nothing to be desired. What a pleasure it must be to work in such a building!

\section{MELBOURNE UNIVERSITY AND MIEDICAL SCIIOOL.}

The Melbourne University is indebted for its foundation to the public enterprise of the late and well-known English statesman, Mr. Hugh Childers, formerly an inspector of schools in the state of Victoria, and to $\mathrm{M}[\mathrm{r}$. Latrobe, its first governor. The former introduced a bill into the legislative comncil for incorporating and endowing the University of Melbourne in 1853. The bill met with little opposition and was passed the same year. The miversity commenced work with three professors and 16 students in April, 185.5. At the anmual examinations of students in 1899. 341 passer. Its present attendance is from $\% 00$ to 800 , of which number about 250 are medical students. It receives an annual endowment of $\$ 45,000$ from the government which, with the gifts, bequests and fees, suffice to meet the current expenses and leave a sufficient residue for making improvements as needed. The buildings are not so expensive as those of the Sydney University. The whole university plant consists of a group of buildings. each of which is devoted to the department for which it is intended. For instance, the medical school is made up of a number of separate one-story stone or brick buildings, representing as many departments. Melbourne Hospital and the Children's Hospital furnish the clinical material. Professor Allen is dean of the medical faculty and professor of anatomy and path- 
ology. He is a remarkable man. He is a graduate of the university and has aequired his professional knowledge of anatomy and pathology by the lardest kind of work within the shadows of his beloved alma mater. The choicest fruit of his ceaseless labor has been $d$ pathologic museum containing thousands of the most interesting specimens, which he has prepared and labeled with his own hands. Besides this, he keeps a record of all the findings of the postmortem examinations at the Melbourne Hospital and has also filed away the clinical history of each case. I believe he could walk through the great museum hall and pick out any particular specimen blindfolded; not only this, but he could give the astonished visitor a minute description of them all. He shored and demonstrated to me scores of the rarest and most interesting specimens. He has one of the finest collections illustrative of the pathologic anatomy of hydatid, actinomyeosis and bone disease. He relies on wood alcohol in the preparation and preservation of the specimens. The specimen jars are corered with heary tin foil, which can be removed and replaced with the ntmost ease, and the tin foil cover properly applier over the mouths of the jars effectually prevents the eraporation of the liquid, the loss during a rear from this souree being insignificant. Professor Allen has become satisfied from his immense experience that malignant disease among the aborigines is extremely rare; on the other hand. syphilis is very common. Everything in his museum shows system and order, a beantiful and rich workshop for anyone who seeks information in this branch of medical study and teaching. Professor Allen knows how to get the best work from his students. He has published a little inter-leaved book, "Pathologica] and Histological Methods of Sections," for the junior students, in which a brief description is given of the mechanical part of the work and the blank pages are filled in by the students with notes and drawings. A similar plan is followed in the bacteriolngic laboratory. 
ADELAIDE UNIVERSTY AND MEDICAL SCHOOL.

'The University of Adelaide, the youngest and smallest of the Australian universitics, was ineorporated in 18\%4. It commenced work two rears later with the Arts course. Other schools were gradually added until the university was able to give its students, besides degrees in arts, degrees in law, medicine, science, music, agriculture and engincering. It receires a substantial government aid and has been endowed by a number of handsome donations and bequests, among them one of $\$ 480,000$ by the late Sir Thomas Elder. The Elder Conservatory of Music, opened in 1898, commemorates this munificent gift. Its present attendance does not cxceed 400, of whom about 120 are medical students. The primary branches of the medical school are taught in separate buildings. The anatomy building, the real home of Professor Watson, is a large one-story brick building. Here he dwells among his students from morning until dusk, often unconscious of the lunch hour, his mind bent on unraveling the mysteries of human anatomy and in supervising, directing and encouraging the students in their work. If any new discorery is made in anatomy anywhere in the world he is sure to learn of it, test it, and make use of it in his teachings. He takes special delight in demonstrating to his students Byron Robinson's utero-ovarian circle. He fully appreciates the importance of applied anatomy and never loses an opportunity to show the intimate relationship between it and operative surgery. A visit to Adelaide without seeing and knowing this interesting man would be about as mprofitable as a journey to Rome without seeing the pope or at least making a visit to the Cathedral of St. Peter. Another most interesting member of the medical faculty of Adelaide University is Professor Stirling, professor of physiology and director of the natural history museums. A combination of these two important offices makes 
him one of the busiest men in Adelaide. He is equally at home in his physiologic institute as in the great hall of the museum erammed from floor to ceiling with the choicest specimens of the animal and regetable kingdoms of his own country as well as from all parts of the world, and the products of man's ingenuity from the stone age up to the most recent inventions. This part of his work is to him a labor of love. He has made this museum what it is, the best in Australia and the peer of many in countries that count their age by centuries. From what has been stated it must become clear to anyone that the Australian universities offer to medical students advantages and opportunities equal to if not superior to any of the medical schools of America and the United Kingdom. It would be folly for any Australian medical student to cross the ocean in either direction in search of something better, because if he did he would certainly meet with keen disappointment.

Colombo, Cexlon, Aug. 25, 1904. 


\section{CEYLON.}

FROM AUSTRALA TO CEYLON-ISLAND OH CEYLON, ITS

CIAMATE, PEOPLE, DISEASES-COLOMBO GENERAL,

CIVIL HOSPITAL-CEYLON MEDICAL COLIEGL-

CEILON IEPER COLONY-LEPER BUUDIIST

CELEBRATION-KANDY GENERAT,

CIVIT HOSPITAL.

The royage from Adelaide to Colombo takes fourteen lays. I left Adelaide August 11 and arrived at Colombo on the $24 t h$, a little alead of the stipulated time. The only rough weather we encountered was for four days in crossing the great Australian Bight, a part of the ocean that has an nnenviable reputation with people who are subject to seasickness. Onr good, staunch, storm-tried ship, the China, played with the foamcrested waves by a graceful combination of rolling and pitehing which, mavoidable and well intended, brought about the usual result-reversion of the peristaltic action of the stomach-in a fair percentage of cases among the small number of passengers. It seemed to me, however, that the Australian and English people are, on the whole, less susceptible to seasickness than the more nervous Americans, and a number of the lady passengers always oceupied their places at the table during meal-time. A few hours' stop was made at Fremantle, which gave me an opportunity to see this important western port of Australia and from there make an excursion by rail to Perth, 12 miles distant. Perth is a new and modern city with 25.000 inhabitants. The activity in the principal streets reminds one very much, at least on a small scale, of State Street in Chicago. The business importance of both these 
western Australian cities depends largely on the rich gold mines in that section of the country. Fremantle has a public hospital with accommodations for 40 patients; the hospital at Perth is a new and modern building with a eapacity for 200 patients. As we left the harbor of Fremantle we were followed by our faithful escort of albatrosses, which had never deserted us in the open ocean since we left the New Zealand coast, but on this occasion these magnificent living kites of the air left us at dusk the first day out, never to return. With the exception of occasional schools of flying fish, water and air were sterile from coast to coast. Cool weather continued for two days after leaving Fremantle, when the winds gradually subsided, the sun displayed his tropical properties and the drizzling rains saturated the atmosphere with moisture, all of which made the heat very oppressive. Blankets and heavy clothing were laid aside and the officers set the example for the wearing of clothes appropriate for the tropies. The low palm-fringed coast of Ceylon, lightly veiled in a rising fog, came in sight Wednesday morning and during the forenoon we were comfortably quartered at the Grand Oriental Hotel, Colomho.

\section{CEYLON}

The island of c'eylon, called Singhala by the natives, is about 55 miles from the southern extremity of Hindustan, from which it is separated by Palk Strait. It lies between $5^{\circ}$ and $9^{\circ} \mathrm{N}$. latitude, hence in the very midst of the tropics. The interior is mountainous, the highest peaks being Pedrat, Allagalla and Adams' Peak; the former rises to an altitude of 8,200 feet, the latter 7,420 feet. The island is noted for its tropical forests, impenetrable jungles and luxurious vegetation. This island has had an eventful political history. It was taken possession of by the Portuguese in the seventeenth century, passed later into the hands of the Dutch by conquest. and was finally annexed to the British 
crown in 1295. The two first nations never conquered the entire island, and the British forces underwent many hardships and met with ficec opposition in the interior of the island before the last rebellion was suppressed in 181\%. Since that time the peace of the island has never been disturbed and it has become, under a wise, conservative govermment, the wealthiest and most prosperous colony of the British empire. The principal articles of export are tea, coffee, cinnamon, cacao and cinchona bark. The cocoanut palm, which is found here in all its productireness along the seashore, in the lowlands. valleys and high up on the hillside, not only furnishes the natives with a considerable part of their sustenance, but is an important source of revenue. The annual value of the produce of this tree alone amounts to $\$ 10,000,000$. In looking at the palm forests of Ceylon no one could forget what this tree does for the untutored natives, as

"It is meat, drink and clothes to us."-Rabelais.

And one who would not think almost instinctively of the beautiful words of the psalmist:

\footnotetext{
"The righteous shall flourish like the palm tree; he shall grow like a cedar in Lebanon."Psalms xeii, 12.
}

Ceylon supplies the markets of the world with cinchona bark, amounting to about a million of pounds a year. The cinnamon tree is indigenous and reaches a height of from 40 to 60 feet and a circumference of from 3 to 6 feet. The cinnamon bark, however, is not obtained from the old trees, but from annual shoots from a very short stump, which is pruned and sprouts from year to year. Another important source of revenue is the more than 4,000 gem quarries. Ceylon has now more than 1.500 miles of railway, over 2,000 schools, 36 newspapers and upward of 100 hospitals and dispensaries. The Ceylon tea is the best in the world. and since it has been found that the hardy shrub which grows this commolity will thrive hest at an altitude of 
r.000 feet, the forest: are rapilly making way for the tea industry up to an altitude of 6,000 feet. As an important protection against deforestation from this and the timber industry the government has wisely stopped the sale of timber land above an altitude of more than 6,000 feet. Cerlon is the paradise for the hunter, as large herds of elephants still inhabit the jungles at a safe distance from human habitations and buffalo, elk. deer, bear and wild boar. as well as a great variety of birds, are quite plentiful and furnish the best opportumities for most interesting sport. The scientist finds here an endless field for study and investigation. The great fertility of the soil, the copious rains and the variations in the elimatic conditions on different parts of the island have created a vegetation noted for its luxuriance and endless variety. The forest trees alone are a great attraction. We find here the satin, sandal and ebony trees, from which the most valuable timber is obtained. It may not be generally known that less than one-third of the wood of the ebony tree (Diospyros ebenum) is black, and this is found in the center of the stem; the outer two-thirds of the wood is white and without value. In the botanical garden at Kandy I saw an India rubber tree (Ficus elastica). planted by the Duteh in 1833, which has reached a height of 130 feet, and the multiple stems and their colossal branches cover a circular area where several hundred people could find protection against rain and sunshine at the same time and be much less erowded than in the streets of Kandy at a Buddhist celebration. In the same place I saw a nux romica tree more than 50 feet high with a graceful crown of small elongated deep green leares in a state of budding for the next year's crop of dise-like nuts so familiar to the phrsician as the source of strychnin. The bo-tree (Ficus retigiosa) is one of the giants of the forests. Its broad acuminate leaves tremble in the breeze like the leaves of our aspen. The trunk is very short and from the top 
the treelike branches form a wide-spreading crown. This tree is worshipped and is held in great reneration by the Budlhists. A very strange tree is what is known as the jack tree, a large tree which bears the largest edible fruit known. The fruit is suspended from the trunk and the larger branches by a short stalk, and in several instances it sprouts from exposed roots. The edible part of the fruit is a ycllow pulpy viscid mass. The smell and taste of the fruit when ripe are strong, and to the European unpleasant, but the flavor is akin to that of our may apple and quite agrceable, at least it proved so to me. The elephant is very fond of the leaves of this tree. The Areca palm, a very slender tree, grows a nut which bears in its structure a close resemblance to the nutmeg. This nut, scraped and mixed with a white paste made of slacked lime, served on a green leaf, is the betel so much in use by the natives as a chewing material. This practice is no worse from a hygieuic and esthetic standpoint than the ehewing of gum and tobacco by Americans, but the betel contains a red coloring material and its habitués do not improve their looks by the red lips, tongue and teeth, which looks to the uninitiated very much as though the chewers, instead of enjoying the pastime, might be the subjects of purpura hemorrhagica, or had just escaped from the chair of an aggressive dentist. How helpless the practitioner of medicine would be if Ceylon did not supply him with cinchona and nux vomica, to say nothing of cloves, cinnamon. cajeput, pepper, nutmeg and other aromaties and carminatives with which we are in the habit of disguising the taste and smell of more powerful drugs and which often prove so efficacious in the treatment of slight gastro-intestinal derangements. But there are still morc remarkable trees in Ceylon, which prove the perfect foresight of the Creator in meeting urgent wants of man and beast. Wherever there are cocoa palms, man's immediate wants arc met, as it supplies him with drink and meat; the milk of the unripe 
fruit will quench his thirst and the meat of the ripe nut supplies him with food. The rain tree (Inga sausa) is a large tree with thick, short stems and widelyspreading branches. Around the lake of Kandy these trees are of enormous size. It has a pinnatifid leaf like the acacia. In the evening these leaflets fold themselres into a small cup, in which the falling dew is collected and retained until sunrise. when it unfolds, and in doing so the thousands of drops of water give rise to a shower on a small scale, hence the name "rain tree."

Ceylon is the home of a great variety of palms. Of these the talipot palm is one of the most remarkable. For the first ten years it grows only from seaped leares. Next the stem grows as straight as a mast to a height of 100 feet. Each annual growth is indicated by a ring. The fan-shaped leaves are of enormous size, sometimes 15 feet in radius. They are so large that three leaves make an ample and waterproof tent. The leaf, cut into pieces of convenient size, has been used for centuries as a substitute for writing paper.

In the octagonal tower of the Temple of the Tooth at Kandy thousands of manuscript volumes record the early history of India on strips of the leaves of this palm. When the tree reaches maturity it derelops a gigantic bud at the end of a pole-like prolongation projecting 10 to 15 feet above the crown of fronds. This bud in due time bursts with a report and a lovely white blossom unfolds itself and spreads with a pyramid of cream-colored flowers. After this final act of propagating its species the tree soon sickens and dies. It was my fortune to see one of these trees a very short time after bursting of its pod and expansion of the liberated flowers. The undergrowth in forest and jungle is represented by a variety of shrubs. the principal one being the nulu.

The density of the forest is increased by twining plants. many of which, especially the Thunbergia, with 
its beantiful pale blue flowers, reach to the very tops of the highest trees. Orchids, piteher plants, the gorgeous passion flower and sereral species of rhododendrons are worthy representatives of the rich flora of the island.

\section{Climpate.}

When Nature goes to work to ereate a botanic garden she must necessarily have at her disposal a fertile soil and a hot, moist climate, a climate congenial to luxurious regetation, but hostile to man. Such is the climate of Ceylon. The intensity of the heat is made almost intolerable during the rainy season, from February to July, by the saturation of the air with moisture. When I arrived at Colombo the rainy season was practically orer and yet the atmosphere was so surcharged with moisture that in the absence of a breeze, natural or artificially produced by fan or punkah, breathing was a difficulty and the sense of heat distressing, although the thermometer in the shade only showed a temperature of 92 degrees F. The coolest months are Oetober, November, December and January, and the hottest correspond with our spring months. In Colombo it is always hot and the nse of blankets is almost unknown. The continuous heat from one end of the year to the other is depressing and Europeans find it necessary to seek a cooler elimate every three or four years to recuperate. and have to abstain from hard work, mental and physical, as much as possible during their entire residence. In the mountains at an elevation of 2.000 and more feet the nights are cool, and even at Kandy, 1,600 feet above the level of the sea, the nights are often chilly. The chains of mountains traversing the island have a marked influence on the rainfall and temperature of the high altitudes. It is often the ease that on one side of the range it is sultry and fogs and rain prevail, while on the opposite side the atmosphere is dry and cool and a bright sunshine adds to the cherr- 
fulness of the bracing mountain climate, with a reversal of climatic conditions occurring with a change of the prevailing winds. It is well known that a prolonged residence in Ceylon shortens the lives of the Europeans, and consequently those who are obliged to live there find themselves under the necessity of leaving the island every few years for sereral months in order to rid themselves of that lassitude and depression incident to a prolonged residence in the tropics, and to regain their recuperative power that is so essential in resisting the insidious influences of tropical and other diseases.

\section{TIIE PEOPLE.}

The population in 18.1 was $3,008,466$. The natives are increasing very rapitly, as the estimated population of the island on Dee. 31,1902 , was $3,655.26 \%$ This is confirmed by the birth and death rate for the same year; $141, \$ 93$ births were registered and 99.680 deaths. The birth rate was 39 , against $3 \% .5$, and the death rate of $2 \% .4$ against $2 \% .6$ per mille in the previons year on the estimated population in the midnle of the year (Merlical Report of Dr. Allan Perry, principal civil medical officer and inspector general of hospitals, 1902). This record is not in accord with the fate of our Indians and the Polynesians of the islands of the Pacific. whose rapid decimation and eventual extermination followed so promptly the footsteps of civilization. Three explanations deserve consideration in accounting for this difference. The Ceylonese have for centuries been in touch with the outside world by much frequented waterways and they hare, perhaps more than any other primitive race. retained more persistently their original habits, and as most of them are Buddhists they have escaped the fearful consequences of alcoholism so common among other sarage races as soon as the white man satisfies their mortid resire for liquor. The Singhalese and Tamil dn not nneumber themselves with 


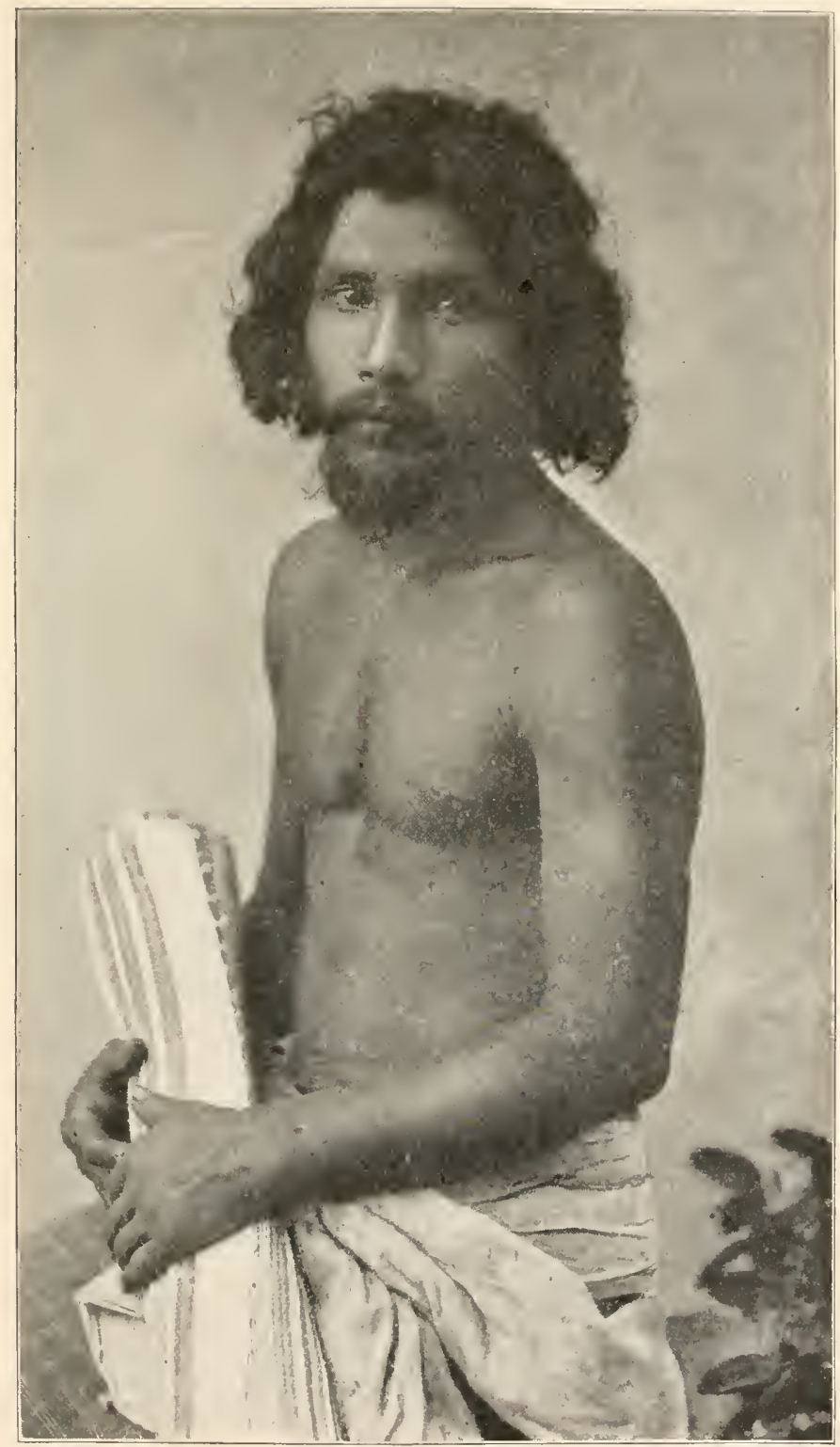

Fig. 33.-A Singhalese. 

European clothes; the comboy (loin eloth) is the only article of dress which he malies use of, and which continues to satisfy all his needs as far as appearance and protection are concerned. 'The diet, habits and manner' of living remain the same. (Fig. 33.) 'The population of Ceylon is a very mixed one, consisting of Singhalese. Tamil, Portugnese, Dntch, Malays, Parsees, 'Turks, Afghans and half-castes of all shades of color between almost pure white and jet black. The Singhalese and Tamils, howerer, form the bulk of the population. 'The Europeans are in a very small minority. The Tamils are the Indian coolies who immigrated from the southwestern part of India and became the laborers of the planters in the interior uplands of the island. The Singhalese are averse to hard labor and have always shown a preference for the plains and valleys. The Tamils are a low race, far beneath the Singhalese in intelligence. The Singhalese is prond of his race. Half-castes bear the hmmiliation bronght on them by the admixture of Emropean blood with a becoming patience and fortitude, but they regard the accident of their birth rather as a disadvantage than otherwise in their social position and best possibilities in life. The question of caste, even in Ceylon. plays quite an important rôle, consequently the Singhalese and Tamil seldom intermarry. The former is a gentleman by birth, and as such is averse to menial work, for which, if he can afford it, he hires the man of burden, the lowlyborn Indian coolie, who in most respects resembles the low-caste Chinese and Japanese. The Singhalese is a very fine specimen of manhood. tall, slender, with long, very thin legs, face clean cut with regular ontlines. well-shaped nose, high forehead, black eyes, bushy eyebrows of the same color, delicate hands, and in complexion varies from a sienna to almost as black as the negro. The hair is long and straight or wavy and is worn by combing it back or parting it in the middle, tied behind into a knot, which is smrmounted by a semi- 
circular comb of tortoise shell. The manner of wearing the hair and the delicate face in the young men with scanty beard and similarity in dress makes it often very difficult to distinguish between the two sexes before advancing age draws more distinct facial lines. The young men appear very effeminate, more so than in any other race that I have ever seen. Tailors and shoemakers do rery little business in Ceylon. With a few rards of cloth men and women itrape themselves very gracefully, learing at least one-half of the body uncorered. The comboys differ only in length from a narrow strip of cloth to a petticoat reaching below the knees. worn by some men and all the women. Another two or three yards thrown orer the left shoulder corers at least a part of the chest and leares the right arm unencumbered. Hair and skin are kept saturated "with palm oil. a rery important hygienic measure, as it preserves the hair and protects the skin against the burning rays of the sun, rain and inscets. The Singhalese are almost free from baldness, as they do not injure the nutrition of the hair follieles by the use of harmful liead-dress and make free use of palm oil, which is undoubtedly an important mutrient to the hair and the hair follicles. (Fig. 34.) The women are much smaller than the men and can make no pretensions to beanty. The flush of youth begins to decline before they are 30 rears old. and then they are inclined to obesity. They are fond of jewelry. Many of them eling to nose and ear rings. toe rings. wristlets, anklets and arm bands of silver. The Singhalese has many excellent qualities: he is checrful, content, honest and peaceable. Theft and robhery are almost unknown. Willful premeditated murder is rery rare. During the year 1903, 36 men were sentenced to death for murder, and of these 22 were hanged: in the other cases the sentence of death was commuter to long terms of imprisonment. Major de Wilton. inspector of police (Prison Report. 1903) makes the following enmments on the crime of murder: 


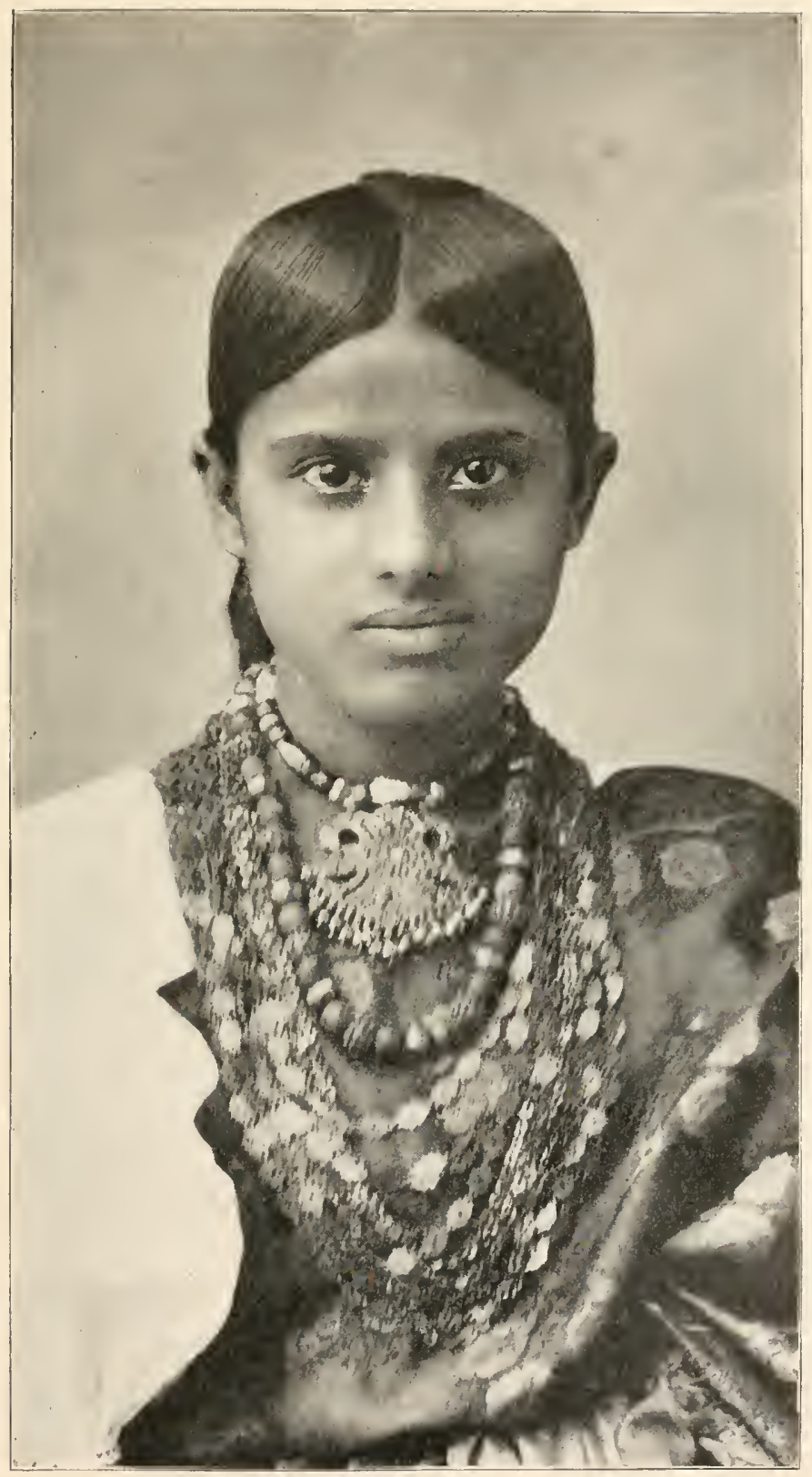

Fig. 34.- Singhalese woman. 

"It is very difficult to make any conjecture as to the anse of the prevalence of the crime of murder. The oflenders do not, as has been repratedly pointer ont, belong to the eriminal class. 'They are, as a rule. men without previous convictions, who mp to the time of the crime have led a comparatively blameless life. 'The oflense is not generally committed with the debiberation of the hardened criminal, but in the fiery heat of passion or under the influence of liquor, and it is a matter of regret that eren the death penalty brings with it no direct eflect."

'The knife is the implement most frequently need when violence is resorted to. 'The number of persons committed to prison for all kinds of offenses during the year 1903 was 2.396, a figure which shows well for the morale of the island. Of 2.508 convictions during the year 1903, 49 were Protestants. 361 Roman Catholics, 1,509 Buddhists, $31 \pm$ Hindoos, 260 Mohammedans; other religions 15. Notwithstanding the heroic labors of missionaries of different denominations for the last two centuries and the expenditure of millions in efforts to convert the natives, the results have been very unsatisfactory. The mass of the people (ling to their Buddhist faith with great tenacity. The bareheaded. barefoot, yellow-robed priests remain in power and attend to the spiritual needs of the people. The Roman Catholic church has accomplished more than any other denomination. Those who hare abandoned Buddhism and have joined a church do not always live in accordance with the teachings of the new religion and continue many of their former customs and practices, which perhaps mnconsciously cling to them from force of habit. For instance. Christianity has made very little impression on the morality of the people. The natives are a temperate people, as the teachings of Buddha prohibit the use of alcohol in any form, and with few exceptions, indeed, the Buddhists are total abstainers. The Singhalese have taken kindly to the professions. The 
most prominent and successfinl physicians and lawyers in Ceylon are natives or hali-castes.

IREVAILING DISEASES.

'The bubonic plagne has never had a foothold in Cevlon. This is the more remarkable, as its harbors are visited daily by ships from all Oriental ports and the exemption from this scourge must be due to the extraordinary care exercised by the department of health. Accurate information regarding the present prevailing diseases can be gleaned from the Annual Report of Dr. Allan Perry, principal medical officer of the island.

Malaria.-In the western, eentral and north central provinces malarial fevers were very slight. The disease is most prevalent in the northwestern and eastern provinces. The disease is quite prevalent in Colombo, and observations are now being made to determine the places where infection takes place.

Cholera.-During the year 1902, according to this report, there were $1 \% 9$ cases of cholera, with 116 deaths. The largest number of cases oceurred in Colombo and vicinity.

Smallpox:-There were 146 cases of this discase, with 35 deaths, in the north of the island, and 118 eases were admitted to the Infections Diseases Hospital. Kanatta, which, with two from another province. made 120 , with 32 deaths.

Dysentery. - This disease is equally distributed thronghout the island. It was most prevalent in the central and western provinces. The largest number treated in any one institution was at the General Hospital, Colombo, where 488 cases were admitted, of whom 89 died.

Enteric Ferer.- The number of cases treated in the varions hospitals throughout the island was 242 , with 63 deaths. Pollution of water and milk are the commonest canses of this disease. The cesspit system. 
which exists in some of the large towns, notably Colombo, Kandy and Galle, has much influence in increasing the number of cases.

Leprosy.-The total number of cases reported during the year 1902 was 560 , against 590 in the previous year, being a decrease of 30 cases; 382 cases were treated in the leper asylum, Hendala, and 30 in the Kalmunai wards. The leper ordinance eame into operation at the beginning of the year, and 113 cases have been reported.

Ankylostomiasis. - It seems that this disease, which is so very prevalent, is constantly being introduced from India by Malabar coolies. The disease is increasing. 'There were 1,609 admissions in all hospitals, with $25 \%$ deaths. 'The danger of the disease to life is in the profound anemia, which so lowers the vitality that the victim is carried off by any insignifieant interenrent affection.

Plague.-The Plagne Committee is a standing committee, including besides the principal civil medical officer, the collector of customs of the ports, the government agent and the mayor of Colombo. Regular meetings are held and precantions instituted to combat an outbreak of the disease. All returns of plagne from infecter ports are received by the committce; telegraph accounts of plague occurring in places adjacent to Ceylon are received regnlarly. It is to the eternal watchfulness of this committee and the prompt action of the staff of port surgeons that is due the freedom of the island from this Asiatic disease. Galle continnes to be the plague port; only one case of this disease was reported from the harbor of Colombo during the year. 'The paticnt contracted the disease at Hongkong and was landed and isolated at Galle, and the contacts for this port were placed in quarantine. The patient recovered. Rat destruction was carried ont at the customs premises and by the municipalities of Colombc and Galle. 
Syphilis.-Colombo. Kandy and Galle are provided with a special hospital for the treatment of women suffering from venereal diseases. The total number of new cases admitted was 351 which, with 20 remaining from the previons year, makes a total of $3 \% 1$. Of the $3: 1$ women treated in these hospitals $2:$ were affected with primary syphilis, 68 secondary, 62 tertiary, 4 hereditary, 156 gonorrhea and 54 unclassified syphilitic lesions.

Parangi.-The hospital records show that this disease has steadily increased during the last five rear. The death rate is remarkably small; out of 3,434 admissions for this disease during the year there were only 10 deaths.

Vaccination.-Taccination is carried out vigorously in the island, as is shown by the Report on Sanitation. During the year 149,901 subjects were vaccinated; of this number $r, \% 60$ were revaccinations.

Lack of Sewerage.-In Colombo, Kandy and Galle the feeal matter is removed at night and buried. In Colombo the experiment was made of using the contents of the eesspits as a fertilizer, but it proved undesirable and was abandoned as a failure. What these cities need is a system of sewerage, as they all have an excellent location to carry out such a plan with success.

SOYSA BACTERIOLOGIC INSTITUTE, COLOMBO.

Since its opening this institution has undertaken work of diverse charaeter, and is now supplying a longfelt want in the colony by its researches in bacteriologic analyses of tissues, secretions, blood, ete., so indispensable to scientific diagnosis of diseases. The acting director, Dr. S. C. Paul. F.R.C.S.. is consulted by government medical officers and private practitioners for reports on specimens submitted to him on bacteriolngic and allied subjects. 


\section{CITY OE COLOMBO.}

The city of Colombo is an important port and the largest city in the island. It has a very mixed population of 128,000. Nore Enropeans live lere than anywhere else in Corlon. 'The steamers anchor' some distance from the wharf. It has excellent strects, the socalled red streets, a bright red from the color of the soil, electric lighting and electric tramways. 'The Grand Oriental Hotel, near the wharf, is the best hostelry in the island. Every room has an electric fan-a great comfort to the traveler throughout the entire rear. 'The rooms of the hotel are never locked, as stealing and robbery are almost nuknown. The crowd of chambermen and servants are always ready to wait on the guests and understand to periection the system of exacting a substantial tip. At present writing the temperature in $m y$ room, in spite of the faithful fan, registers 91 F. The air is thoroughly saturated with moisture. which is accountable for the oppressive sensation of heat that every newcomer experiences.

The Cimmamon Gardens is the city park and is a lovely place. The drives along the coast are beantiful and disclose at every turn the luxurious regetation of this wonderful island. The natice policemen are courteous and deroted to their duties. They are fully impressed with the responsibility and dignity of their office, and cross and recross their beats with a keen eye for any evildoers. The city has a museum. free library and many charitable institutions for the sick and poor.

\section{THE GENERAL CIVIL HOSPITAL.}

The hospital is made up of numerous one-story brickand-mortar pavilions connected by roofed colonnade, cemented walks which impart to the whole complex of buildings a fine architectural appearance. The snowwhite walls and pillars and the red tile roofs are in strong and beantiful contrast with the perennial green surrounding the building inside and outside of the 
large square cont which they inclose. The income from pay patients is not larwe, but the govermment appropriations are liberal. All of the employes are salaried, including physicians, internes and nurses. Dr. Thomasz, one of the two attending surgeons, receives 4,000 rujees a year. He condueted me through the different wards and showed me many interesting surgical and medical cases. The nursing is in care of thirteen Anglican sisters and a number of women nurses, gradmates from the Lady Havelock Hospital. A corps of native men and women act as helpers. The wards are airy, well lighted and furnished plainly hut comfortably.

Echinococcus, so common in Australia, is not seen here; on the other hand, elephantiasis is quite common. Dr. Thomasz has operated on a number of cases of scrotal elephantiasis with success. The natives are not very good subjects for prolonged major operations, as they are rery liable to inordinate shock. Chloroform is nserl as a general anesthetic, and in sereral thousand ancsthesias only two deaths occurred. The operating loom is old and not up to modern requirements. The equipments and appliances also leave much to be desirer. Asepsis has not succeeded here as well as could be desired and the many failures to obtain primary wound healing having finally led to the abandonment of buried absorbable sutures of any kind. Silk is used almost exclusively and the sutures are remored from three to seren days after the operation. The same practice is followed in the Kandy General Hospital. In the ontiloor department I watched an interne dress two recent wounds. He lid not remove his coat, and a basin with some antiseptic solution was relied on in performing primary disinfection. Not much time or effort was expender in preparing the wounds for suturing. and I have little doubt that the sutures rather retarled than assisted Nature's efforts in repairing the wound.

Ovarian tmmors are quite common. but myofibroma 
is rare among the native women. Women the subjects of ovarian cysts of enormous size frequently enter this hospital for operation. Little operating is done in the country villages and patients usually do not seek medical advice until they are much inconvenicnced from the size of the tumor. Prostatectomy is performed by the suprapubic route. Stone in the bladder is not of frequent occurrence. Tuberculosis of the lungs is quite common, as during one year, 1901-1902, 956 cases were admitted to the different hospitals. Surgical tuberculosis is much less prevalent, as during the same year only 60 cases of tuberculosis of the glands of the neck were treated, 32 of lupus and only 5 cases of tuberculosis of the joints. I did not see a single case of spinal deformity among the thousands of people I saw in Ceylon and only one case of ankylosis of the hip and 2 cases of ankylosis of the linee joint, and very few cases of tuberculosis of glands of the neck or its remote result, scarring of the neck. Only 12 cases of snakebite are reported for one year, of whom 2 died.

SEPTIC THROMBOPHLEBITIS OF THE SPERMATIC VEINS.

Dr. Thomasz a few years ago described a form of septic thrombophlebitis occurring in young men the subject of varicocele; the immediate cause is usually an injury of some kind which induces the thrombosis. When this has taken place the pus microbes find in the obliterated lumen of the veins a favorable soil for their reproduction, which leads very rapidly to pyemia and death. The disease pursues a very acute course and is nearly always fatal unless an early radical operation is performed, which must also include the testicle on the affected side.

\section{CEYLON MEDICAL COLLEGE.}

The Ceylon Medical College was formally opened on June 1, 18\%0, with one principal and three lecturers. The first intent of the school was to be "simply an elementary school." The faculty was increased three years 
later and in 1888 it became a regular medical college with power to license in medicinc and surgery. Lady students were admitted to the college for the first time on May 5, 189:. The onc-story building of the college, with library, lecture rooms and laboratories, was erected at the expense of the late Susew de Soysa. The dissecting room is a separate building. as well as the laboratory for physiologic and pathologic chemistry. The clinics are given in the General Civil Hospital, opposite the college building. The course of study embraces five years. The teaching force consists of 32 professors, lecturers, demonstrators and assistants. T. F. Garvin, M.B.. C.M., Aberdeen, is a lecturer on surgery, and H. G. Thomasz is clinical lecturer. Physics, biology and elementary zoology are included in the primary branches. All the specialties are included in the faculty. The present attendance of stulents is about 120. The students are given ample opportmity to serve in the hospital as dispensers and dressers, and the clinical material for instruction is very large, including practical obstetrics in the De Soysa Lying-in Hospital. The school has also a department for apothecaries. The standards for admission and graduation correspond with those of the medical schools of the United Kingdom. The fee for the whole course in advance (to be paid in one sum at the commencement of the first college year), is 800 rupees (\$256). A number of prizes and medals have been established by friends of the institution. At the close of the session 1901-1902, the school graduated 26 . the following year only 9 candidates. Part of the entrance and professional examinations are conducted in the Tamil and Singhalese languages. of which the student must have a fair knowledge.

\section{LEPER ASYLUM AT HENDALA.}

I visited this institution, which by the carriage drive is ten miles distant from Colomb. The road leads 
througly at stries of nation villages. rice fields, marshes and strips of primeval forests and demse jumgles. The colony is located on seventeen acees of land enclused by a stone wall. The numerons one-story buildings of brick and mortar are comnceted hy roofed cement walks. 'The entire settlement, exclusire of physicians, numbers 360 , of whom there are only 69 women. The youngest patient is only a years old. One of the patients, a man bo years of ace, has been here for thirty years. $\mathrm{He}$ is attlicted with the ancsthetic form of the disease,

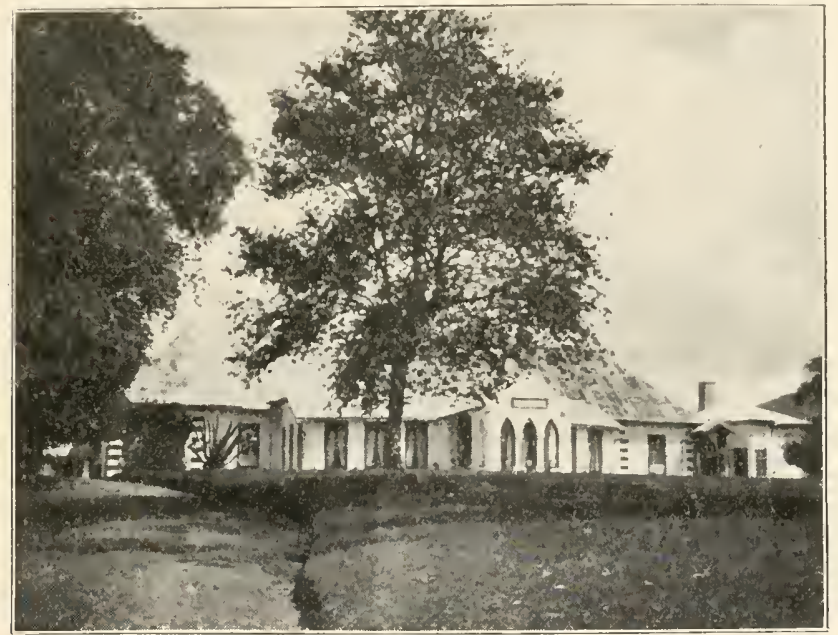

Fig. 3.i-Leper. Isylum at Hendala.

is totally blind and has lost all of his fingers and toes. The disease has cured itself. but has left the patient a helpless, shapeles mass of flesh. It appears that the anesthetic and tuberenlar forms of the lisease oceur about with the same frequency. The institution is well managed and the nurses and two resident physisicians do all in their power to render the existence of these hopelessly diseased victims as comfortable as possible. The patients appeared to be content with their fate and the hmmane restraint that is practiced. The 
law of segregation came recently in force, but the authorities find it difficult to carry it ont with the strictness for which it is intended.

\section{LEPER BUDDIIST CELEBRATION.}

The day I visited the asylum was the annual celebration to the memory of Buddha. It was a gala day, the walk leading from the entrance to the little Buddhist temple was decorated with palm leaves. The procession was formed outside of the gate. There was no elephant to draw the shrine of Buddha perched on a rude cart, but a little humpbacked bullock answered the purpose very well, and he performed his part of the celebration with credit to his kind. A brass band with native instruments headed the procession, then came the shrine followed by a number of bronze-colored yellow-robed priests, and lastly the Buddhist lepers in all stages of the disease. Explosives were thrown against the stone wall, where they exploded with a terrible report. emitting at the same time a blue-black smoke which enveloped the slowly moving procession. The bombardment, with the ear-splitting music of the native band, imparted to the whole affair a weird appearance. When the procession entered the temple silence was restored, and only the murmurings of the priests could be heard ontside of its sacred walls.

\section{CITY OF KANDY.}

This little city of 20,000 inhabitants, the former residence place of the kings of Ceylon, has degenerated into a dilapidated mountain village. It is located in a valley in the subalpine region. surrounded by verdant hills and nestled around a little artificial lake of the same name. It is accessible from Colombo by rail, the road passing the first fifty miles through rice fields, marshes, then ascending for thirteen miles in a zigzag line to the height of $\mathbf{1 . 6 0 0}$ feet above the level of the sea, and then through a valley nine miles in length, 


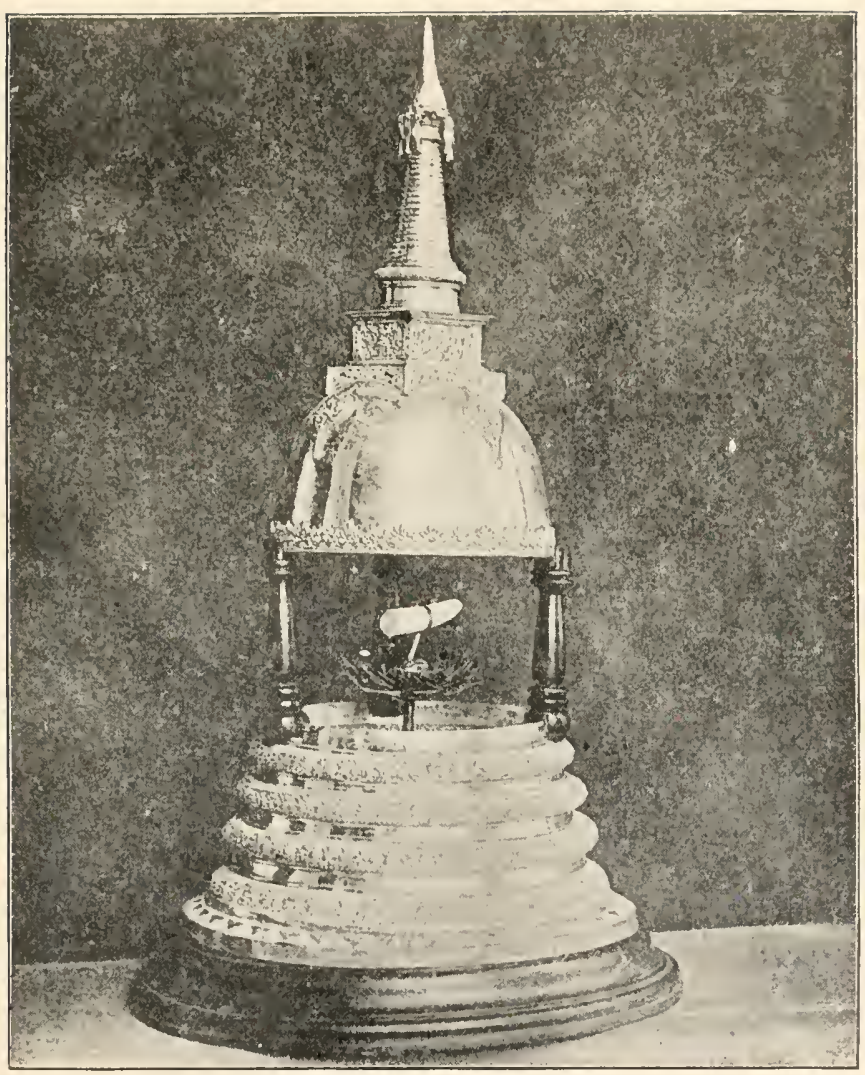

Fig. 36,--Tooth of lsudtha. 

when the little city suldenly comes into view. The beanty of Kandy and its environments have heen greatly exacgerater by sentimental writers. 'The town is noted for the 'T'emple of the Tooth, an old. crmmbling pile of stones which rontains in its most interior and not accessible part a tooth of the famoms prophet. (Fig. 36i). I happened to be in the eity on the day when the Buddhists turn ont in masses to do honor and homage to their deity-Buddha.

THE ANNUAL, BUDDHA CELEBRATION.

For thrce days the little city was packed with a seething mass of humanity. In many places standing room was scarce. The great event took place at 9 oclock Saturday evening. Angust 2\%. The procession, headed by a band of native musicians and three elephants abreast with their riders, was made u]) of ?(i other elephants. an army of chiefs gorgeously arrayed, and bareheaded yellow-gowned priests, dancers with faces disfigured by white stripes, screaming and yelling boys and the faithful followers of the god of whom at least one tooth had remained to testify that he once inhabited this earth; the tooth that was carried in the procession in a shrine carefully guarded. The most solemn celebrants were the 29 magnificent elephants. who marched with slow, thoughful steps, their sly little eyes peeping throngh small holes in their masks of royal red. casting a glance now and then on the sea of humanity on either side of the road. The great mass of people who took an active part in this celebration and the enthusiasm aroused when the hiding place of the tooth of Buddha came into view showed only too clearly that this deity has not lost his influence and power among the natives of Ceylon.

BOTANICAT FARDEN.

The botanieal garden fom miles from Kandy is the most interesting spot in this part of the subalpine region - 
of Ceylon. It comprises thirteen acres of land, included in a horseshoe bend of the Mahaweli ganga. Every known variety of palm can be found here, as well as specimens of nearly all trees and shrubs of the tropics. I saw here a clore tree (Eugenia caryophylata) at least forty feet high, an ebony tree (Diospyros ebenum) and a nux romica tree of about the same dimensions. The towering palms. the dark walks cut through the otherwise impenetrable jumgles, and the gorgeous flowers, of trees, shrubs and plant. make this spot a real paradise on earth, a great contrast to the dilapidated city . of Kandy.

KANDF GENEIAL CIVIL HOSPITAL.

This is a very pretty, comfortable. clean, well-managed general hospital, built on the same plan as the Colombo General Hospital. It is located ontside of the depressing influences of a formerly famous. now crumbling city, in a little vale surrounded by green hills on all sides. The snow-white one-story parilions and the connecting. roofed cement walks lined with square column of the same color. around a central square ornamented with jack and bo-trees, palms and flowerberls, give it the rery picture of isolation. comfort and peace. The 243 patients inside of its walls enjoyed the blessings of careful nursing and the benefits of excellent surgical and medical skill.

Dr. James William de Hoedt is the physician and surgeon in charge, ably assisted by a woman house surgenn. Miss Winifred Tell, L.R.C.P. and S.E. Dr. Nell is not only a very competent physician, but at the same time a skilled naturalist, as I had an opportunity to learn during the visit we made together to the botanical garden. The nursing staff is in charge of an Anglican si-ter. Sister Eustacia Mary, a well-trained nurse and charming lady. I found here a number of interesting emergency cases and the usual predominance of ankylostoma, malaria and enteric ferer. There have 
occurred here in the small maternity ward recently five cases of puerperal tetanus, in all of which recovery took place. 'This lospital has a remarkable record in the treatment of tetanus, 13 cases without a death. Buried sutures are not emplered, silk is used exclusively and the sutures are always removed. Chloroform is the favorite anesthetic and biniodid of mercury is largely relied on in hand and surface disinfection.

Madras, India, Aug. 30, 1904. 



\section{INDIA.}

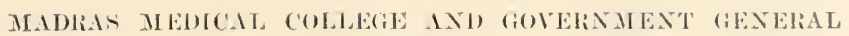
IIOSPITAL.

India, with its $300,000.000$ inhabitants, has only four medical colleges. located at Madras, Calcutta, Lahore and Bombay. All of these medical schools are in affiliation with the respective universities. On recommendation of the medical facilities, the universities confer the degrees, but the medical schools receire no financial aid from the miversities and set their own standards of requirements for admission and graduation. All the medical schools are patterned after those of the United Kingdom as to requirements for admission, graduation and methods of teaching. From information obtained from different sources I find that the great stumbling block of the Indian medical student is language. A knowledge of Latin is a rara avis and the meaning of ordinary English words is hard for them to express and comprehend. The teachers find this imperfect knowledge of the English language the greatest drawback in ingrafting their ideas into the minds of the students. The number of medical students in the different institutions at the present time is about 2,000. Tery fer Mohammedans study medicine; the great majority of students are Hindus and Parsees. The Hindus are said to be the brightest students. The classes have increased in size very rapidly during the last few years, so rapidly, indeed, that space and equipment in all of the schools have become entirely inadequate. From what I have seen of the students in the different mertical colleges I have become impressed with their lively, cheerful dispositions and their earnest devotion to their work. The 
teaching force, as a rule, is inadequate in number in all the schools. and in consequence the men are overworked. I will give only one striking instance of this kind. Lientenant-Colonel Dimmock of Bombay is director of the Jamsetjee-Jeejeebhoy Hospital, principal of Grant Medical College, and professor of obstetrics, gynecology and diseases of children. Enough work for five men under ordinary circumstances. The men of

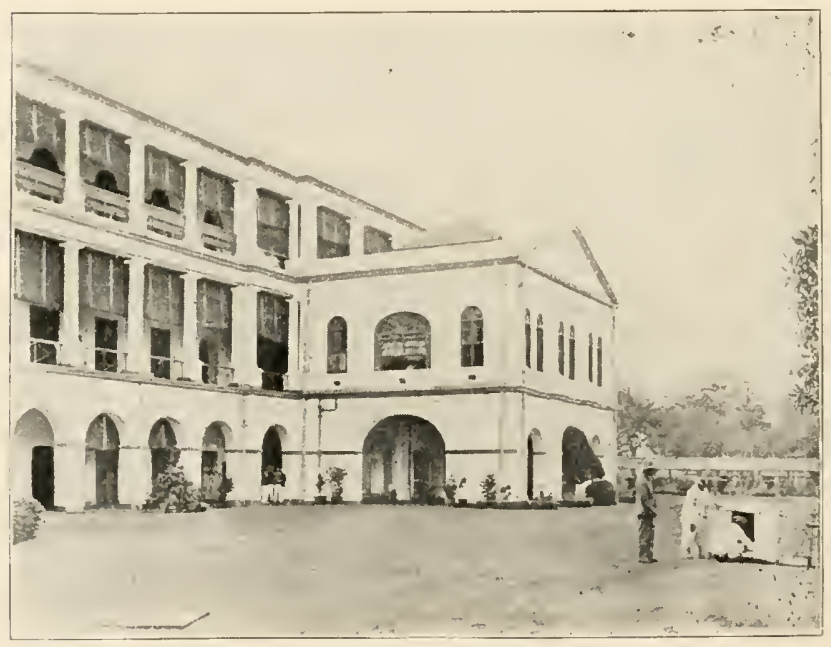

Fig. 37.-Marras Medical College and Government General Hospltal.

the Indian medical service who are engaged in medical teaching are overworked and underpaid, and they are the men who do more for India than any other class of men.

\section{MADRAS MEDICAL COLLEGE.}

The Madras Medical College was originally established as a medical school in 1835 (Fig. 3\%). The classes received their instruction at first in rooms adjoining the quarters of the surgeon general of the general hospital. The main building of the school was opened in 1836 and then consisted of four apartments- 
a theater or lecture romm, a liliary, a museum and a laboratory. 'The shool commenced with a teaching force of seven, 10 modical apprentices and 11 native medical pupils. J'rivate students were first admitted in 1838. 'They obtained, in common with govermment students, a free ducation. In 1851 it became a college, and in $185 \%$ it was placed in the list of affiliated institutions. The buildings were altered and enlarged in $186 \%$ In 1885 separate anatomic buildings were erected, to which were added a theater with a dissecting room

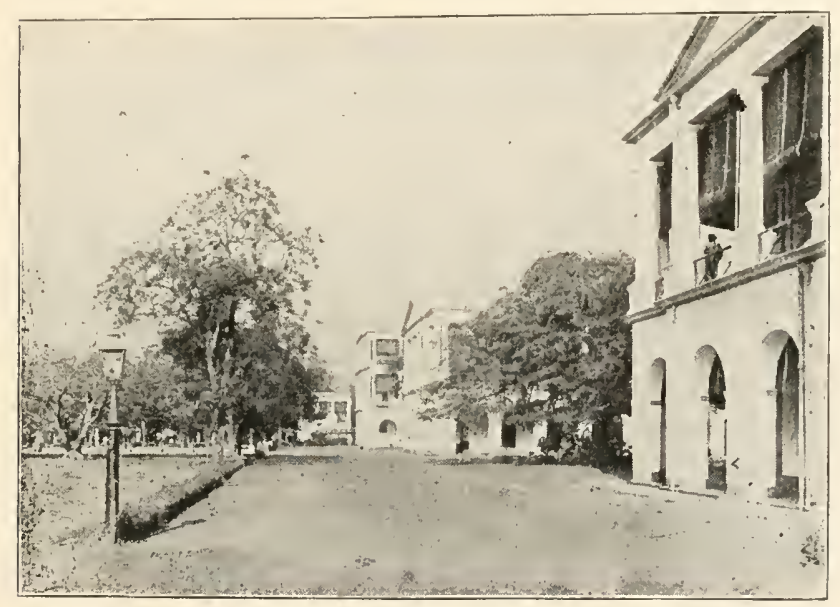

Fig. 39.--Another view of Madras Medical Collexe and Government General Hospital.

for the pupils of the hospital assistant department and a musem in 188\%-S8 (Fig. 38). Separate buildings for biologic and hygienje laboratories followed. In $18 \% 5$ the college admitted on its rolls three new classes of students-viz., candidates for the degree of licentiates in medicine and surgery, for the new grade of civil apothecary, and female students. The system of free education for the students of the college department was abolished a year before this department har been closed, in order to allow the professors to devote themselves to the teaching of subordinates for the service of the 
government. For the second time the hospital assistant department was transferred to the auxiliary medical school at Ráyapuram in 1903. The principal of the college at the present time is Lient.-Col. J. Maitland, M.D., I.M.S., F.M.U. The teaching staff consists of 23 professors and assistant professors, and the number of students is 400. Major G. G. Giffard. I.M.S., is professor of surgery, and Miss $T$. Adlams, M.B.. lecturer in midwifery to female students. The calendar of the college for 1904-1905 contains the following regulations :

DIESS-FOL NATITES ONLY.

1. The typical dress: Turban. a long or short coat buttoned up to the neck. trousers, socks and English shoes. Underclothing according to choice, but where the material of the coat is not washable, e. g., tweed, a linen collar should be worn. and, if the coat does not button n1, to the neck, collar and tie must always be worn, whatever the material. The Parsee hat and Burman head clotl are. for the purposes of these regulations, to be regarded as turbans.

2. Modifications permissible: (a) Students who wear a "tuft" or who shave the scalp must wear a turban which must conceal the tuft when it is present.

(b) Students who dress their hair after the European fashion may wear caps, but indoors, if their dress is otherwise European, the cap must be removed. (c) A cap when worn must be black and may have a lace border, but not otherwise decorated-and no caps are allowed to be worn on ceremonial occasions, such as prize distribution, etc. Mohammedans may be allowed to wear the fez on ordinary occasions, but not at ceremonial observances. (d) Any student may wear a dhote or mundu: he must then go barefooted indoors or wear socks and European shoes. The latter are recommended, as the feet are apt to get soiled or inocu- 
lated with septic matter either in the hospital wards, dis-ecting rooms or out-patient rooms.

3. All articles of dress, whatever the material, must be clean.

This dress regulation must certainly interest our American students, as even with these restrictions the sight of a class of students of the medical colleges of India is a rery much checkered and picturesque one. probably made up of more colors than the checkered coat of Joseph. The candidates for the M.B. and C.MI. section must have passed the first examination in arts of this miversity, or an examination accepted by the syndicate as equiralent thereto. The course of training for this class extends over five rears, and the fees charged for tuition are:

\begin{tabular}{|c|c|c|}
\hline For the first yea & $\begin{array}{l}\text { Rupees. } \\
\text {. } 100\end{array}$ & $(\$ 32.00)$ \\
\hline For the second year of study & $\ldots 155$ & $(49.60)$ \\
\hline For the third year of study. & $\ldots 155$ & $(49.60)$ \\
\hline For the fourth year of study & $\ldots 100$ & $(32.00)$ \\
\hline or the final year of study. & $\ldots 100$ & $(32.00)$ \\
\hline
\end{tabular}

Or if paid in one sum on joining college. 500 rupees, equivalent to about $\$ 160$.

The course for the L.MI. and S. degree extends over four years and the fees charged for the whole course if paid in adrance amount to $4: 0$ rupees $(\$ 150)$. The candidates for these degrees are obliged to pass only three examinations. The first examination includes one course in each of the following branches: Anatomy, physiology, chemistry, practical chemistry, practical pharmacy, histology. The second includes one course in medicine, surgery, materia medica and therapeutics, general pathology. practical pathology and bacteriology, hygiene, practical hygiene, medical jurisprudence, minor surgery. The third and final examination includes midwifery and diseases special to women and the newborn child, ophthalmology. mental diseases and operative surgery. The examination test for the degree of M.B. and C.M. is much more severe. Provision is 
inacle for the education of military pupils for the Indian subordinate medical department, colonial apprentices, apothecaries, male and female, and chemists and druggists. Is an inducement for diligence on the part of the students the Madras Medical College offers ammully nine medals, eleren prizes and ten scholarships.

\section{MLADRAS GOTERNALEXT GENERAL FIOSPITAL.}

This institution is intimately connected with, and in fact is, the clinical part of the Madras Medical College (Fig. 3i), all of the attending physicians and surgeons being members of its faculty. The hospital is made up of a number of two-story pavilion buildings around a capacious square court ornamented with tropic trees, shrubs and flowers. The buildings harmonize with each other. It can accommodate 450 patients. The amount and variety of clinical material in this institution is simply enormous. The operating theater, while not up to all of the modern requirements, is one of the best in India. Chloroform is the routine anesthetic. The farorite suturing material is silk and silkworm gut, as the use of absorbable sutures has given rise to many disappointments. Biniodid of mercury is the farorite antiseptic for hand and surface disinfection and sterilized gauze is used for dressing wounds. I found a great many emergeney cases in this hospital, fractures and accidental wounds, as well as a number of cases of abscess of the liver recently operated on. Among the most important cases was a man who was admitted into the hospital a few davs previously with a strangulated inguinal hernia of four days' standing. Professor Giffard performed the operation. The bowel was gangrenons. Enterectomy was done, the continuity of the bowel restored by suturing, and the patient is recovering without haring shown any untoward symptoms since the operation. Although inguinal hernia is met with quite frequently in Madras, femoral hernia is very rare, only one case being admitted to the hospital during the 


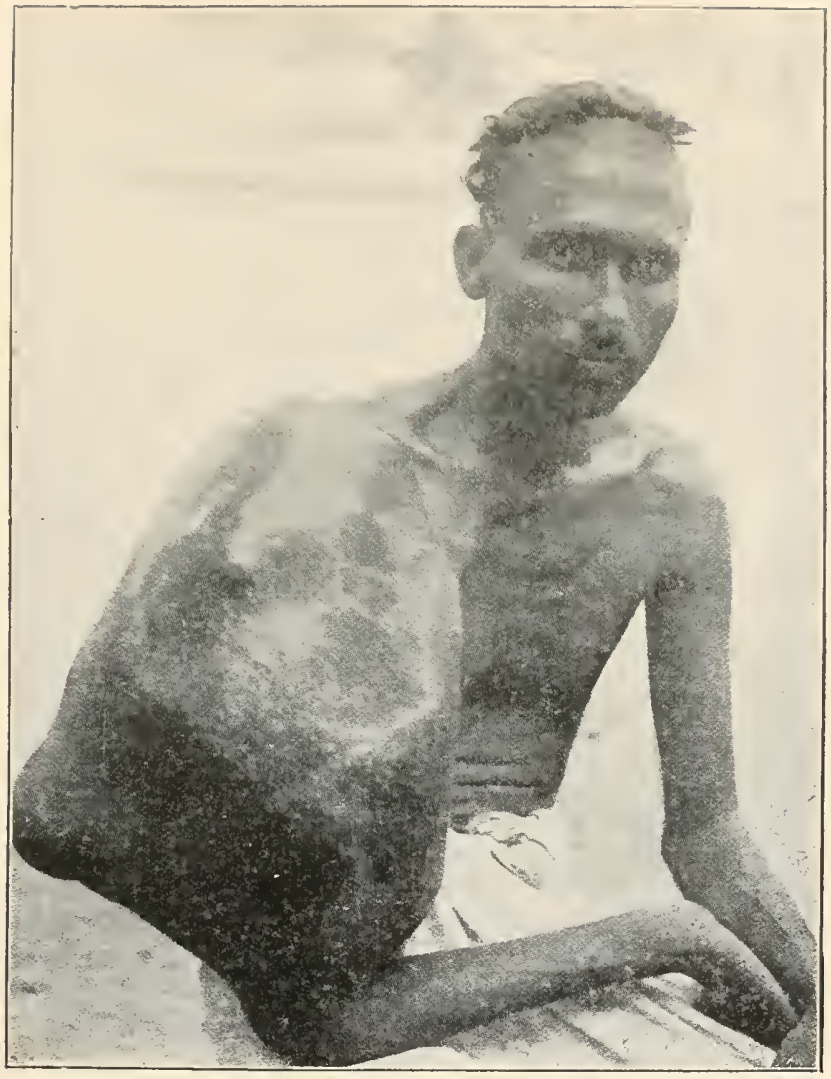

Fig. 39.--Chondrosareoma of humerus and scapula. Successful interscapular amputation performed by Captain Niblock, I. M. S. of Madras. 

past :0 years. (Giffard.) Elephantiasis of the serotum is rery frequently operater on in this hospital. Lient.-Col. Maitland has performed this operation 160 times with most excellent immediate and renote results. Stone in the blankler is very common in this part of India. Crushing is the favorite operative procedure. Many surgeons, among them Profusor Giflard, prefer to perform the operation through a merlian perineal incision insterd of the lateral, and in case the stone is too large to be removed by this method it is extracted whole or in fragments through a suprapubic incision.

\section{CARCINOMA IN INDLA.}

An unusual number of cases of cancer of the month find their way into this lespital and its frequeney is attributed by the surgeons to betel chewing. Two pathologic forms are distinguished, the papillomatous and ulcerative, the latter being much more malignant and pursuing a very acute course. Capt. IV. J. Niblock, I.M.S.. surgeon Govermment Hospital, has contributed a very important article to the literature of "Cancer in India," published in the Indian Medical Gazette. May, 1902. The paper is based on the clinical records of this hospital. He has the following to say regarding betel chewing as a canse of carcinoma of the cheeks and jaws: "On looking at Table $1 \mathrm{~d}$, one can not aroid being struck very forcibly by the enormons number of patients shown as armitted for carcinoma of the cheek and jaws. Carcinoma of the check alone accounts for almost one-third, and carcinoma of the cheek, jaws and tongne taken together for more than one-half of the total admissions of carcinoma cases. The check is the part most commonly affected in Hindus and Mohammedans, males and females. The discasc affects the buceal surface of the cheek, generally commencing opposite the teeth of the lower jaw and spreading with varying rapidity. The frequency of carcinoma in this situation. in my opin- 
ion. Wue to the chewing of 'betel;' a common habit in this country, and indulged in. I believe, by almost all classes of natires. 'Betel.' as used in the Madras presidency. is said to be made up of the following parts: (a) The essential constituents, riz.. 'betel' leaf, areca nut, and canstic lime (chunam). (b) Condiments, such as clores, nutmeg. cardamons. cubebs. Dry powdered cocoanut and oil are also sometimes added. The above components are mixed in rarring proportions, rolled up in a betel leaf, and placed in the month. They are then chewed and rolled abont hy the tongue and cheek for a period rarying from 10 to 30 minutes and then spat out."

I can tostify from observation to the universal use of betel both in India and Cerlon. Carcinoma of other parts of the hody appoars to be more rare than in our comntry. The tables of Capt. Niblock show, for instance. that 513 cases of carcinoma of the mouth were admitexl to the Freneral Hospital during 10 years. 159?-1901. and only 14 cases of carcinoma of the breast and 19 of the lip. Conceming the latter he says: "Epithelioma of the lip. it will be noted. is comparatively rare, and. so far as my experience goes, affects lonth lips with equal frequener. The rarity of carcinoma in this situation is no doubt explainable by the fact that smoking from a pipe (or at any rate a clay pipe) is not indulged in by the natives of this country." The comparative frequeney of carcinoma of the upper lip referred to by Capt. Niblock stands almost i=olated as a clinical observation and constitutes a very important enntrilution to the topography of carcinoma as it is observert in India. Tundreds of cases of carcinoma of the lower lip have come under my observation and only a single case of carcinoma of the upper lip.

\section{ABSCESS OF THE LITER.}

In risiting any of the laroe lospitals in India one is sure to find a fer cases of abscess of the liver, and ret 
Capt. W. J. Niblock says the disease is not so frequent as is generilly supposed. (Notes on aperations for abseess of the liver, ascites, and gall stone. Indian Medical Gazette, Norember, 1903.) In looking through the reports of the Madras General Hospital, lie found that, during the ten years, 1893-1902 inclusive, only 151 cases were operated on, and dming the last three years the arerage annual admissions were at the rate of 63.591. Of the 151 cases recorded, 21 were shown to be multiple, all of whom died. There were 53 deaths among the 133 other cases, several of which were. however. probably multiple, as some of the surgeons who performed the operations made no distinction between single and multiple abscesses in their records. Capt. Niblock reports the result of 29 cases of abscess of the liver operated on by himself from March 25, 1899, to Sept. ?1, 1903. All the patients were males, their ages ranging between $2 \pm$ and $\%$. The racial distribution was as follows: Hindn, 19; Eurasian, 3; Enropean, 5; Mussulman, 2. Out of the 29 cases, 5 were multiple, all of whom died. Among the remaining $2 t$ there were 6 deaths, that is, the mortality was 25 per cent. All of the abscesses containing less than 20 ounces of pus at the time of operation recovered. In the treatment of this affection the anthor of the paper emphasizes the importance of a preliminary exploration of the liver by means of a long needle and syringe.

His dircetions for exploring the liver are as follows: "If a distinct prominence be felt or seen, the needle is first introduced at that situation. Where no such prominence exists. the needle is usually introduced into the lirer through the ninth or tenth intercostal space. After the liver has been pierced. the piston of the syringe is drawn back for an inch or so, leaving a racuum. Should pus now enter the syringe, the latter is retached, leaving the needle sticking in the liver to act as a gmide. If no pus be found, the needle is gently pushed upward, inward and slightly backward, this 
being the most likely direction in which to strike pus. It is gradually withdrawn if no pus is found. and reintroduced in another direction. Five or six different parts of the liver are thus carefully explored before the case is sent back with a negative result." The exploration is made under an anesthetic, and if pus is found the operation is performed at once. After resection of about two inches of the ninth or tenth rib in the axillary line the lirer is exposed by an incision. If adhesons are present the liver is incised at once: if there are no arluesions a strip of gauze is carefully packed all around the proposed line of the risceral incision. Sutures are nerer used, as they tend rather to faror than prevent the eseape of pus into the serons carities. With a small scalpel the capsule of the liver is incised. If the abscess is deeply situated a sinus forceps is pushed through the liver substance into the abscess. followed by the index finger, and the needle is then withdram and one or two Keith's glass drains inserted. After eracuation of the pus one or two large fenestrated rubber drains are substituted for the grass drains and a large aseptic absorbent dressing applied. Washing out the earity with antiseptic solutions is abstained from, although the operator has seen good results from the use of a solution of quinin, 1 in 60 to 1 in 80 , as adrised by Capt. L. Rogers, I.M.S.

The nursing in the Madras General Inspital is in charge of 28 trained female nurses, 31 male warc attendants and 21 female ward attendants. Twelve female nurses resigned during the vear and gave their reasons for this step as follows: Left to be marrierl. 6; left to train as mirlwife, 1 ; retired on pension. ?: retired on account of ill health. 2 ; retired for private reasons, 1 .

The amount of arailable clinical material of this hospital is something enormoms. During the last year the institution cared for 60.842 ont-patients and $2.1 \%$ in-patients. The total number of deaths that oceurred 
in tle hospital was 6.14. Among the most frepuent caluses of death we find malaria. 48; dysentery. ti; tuberenlosis. S3; discases of liver, 38; discases of the urinary organs, to. Cholera is credited with st deaths.

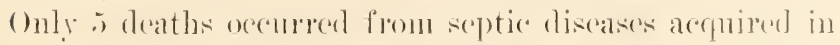
the hospital. They were as follows: (one case of sapremia, 1 case of septic peritonitis after enterectomy, 1 case of erysipelas after operation on tubercular glands of the neck, 1 case of cancrum oris oceurring in a phtient suffering from malaria, and 1 case of gangrene of the leg following the puerperal state in a debilitated woman.

Forty-cight deaths oceurred in eases of septic di:eases contracted ontside of the hospital, namely, 16 from tetanus. 9 from cancrum oris, ? from cellulitis, 3 from gangrene, 2 from shoughing after extravasation of urine, 1 from sloughing of scrotum, 1 from sloughing phagedena of penis, and $\mathrm{z}$ from septicemia (two puerperal).

The total number of operations performed was 6.281 , with a mortality of only 1.9 per cent. Imong the more important operations were 43 for elephantiasis of the scrotum. with 1 death: 8 suprapubic cystotomies for stone, with 4 death. 1 death following a median perincal operation and? litholapaxies, with 1 death; 61 operations for hemorrhoids withont mortality. \& by ligature, 3 by excision and it by clanip and cautery: 10 operations for extravasation of mine, whih 1 death: $: 00$ operations for hydrocele by tapping, tapping with injection, incision and eversion of sac, excision of parieta] part of sac and incision and drainage; 31 castrations without a death: 5 operations for prolapse of the rectum. with 1 cured, 2 relieved and ? deaths: 26 operations for strangulated hernia, with a deaths, and 10. radical operations, with 3 deaths: 31 operations for abscess of the liver, with 3 deaths, and 15 exploratory punctures of the liver, with 1 death from hemorrhage; (i exploratory laparotomies, with 2 reaths: 3 operations for intestinal obstruction. with 2 deaths; oxcision- of 
the appendix, with 1 death, and $\tilde{J}$ incisions for appendiceal abscess. with 1 death; 6 amputations of the thigh. with 1 death, and 10 amputations of the leg, with 1 death.

A few of the operations are of sufficient interest to entitle them to a more extended notice here.

\section{ANEURISM OF COMIION AND EXTERNAL CAROTID}

\section{ARTERIES.}

The patient was a Hindu, aged 22 rears. The pulsating swelling was first noticed a rear ago and measured three inches in diameter at its widest part. Patient suffered from severe pain in the region of the swelling and on the right side of the head, slight dysphagia. paralysis and wasting of the right side of the tongue. The common carotid was ligated below the omolyoid October 20. The pulsations in the swelling facial and temporal arteries ccased at once and never returned. The swelling stearlily decreased in size, but as the progress was too slow to satisfy the patient it was later incised at his urgent request, the coagulated bloor remored and, as no hemorrhages attended the operation. the wound was sutured withont making provision for drainage and healed by primary intention.

\section{IIYDATID CYST OF TIBIA.}

Operator. Captain Niblock. The patient, a Hindu ryot, aged 30, was admitted to hospital for a tumor of the upper end of the right tibia. He gave a history of the swelling commencing seven months before and gradually increasing; also of indefinite pain and weakness in the leg for two years. Pain nerer serere. The tumor on examination was hard. smooth, and fairly regular in outline, no eggshell crackling. The tumor was riagnnsed as possible myeloid sarcoma, but on being incised it was discorered to be a hydatid cyst. containing about 10 ounces of fluid. The crst wall was remored thoronghly and the bnny shell of the cyst broken and 
turned inward so as to partially fill the carity. He left the hospital cured in four months.

\section{RIIINOSCLEROMA.}

The paticnt was an Eurasian, 21 years old, fireman by occupation, resident in India since birth, spent most of his time at Bhumda Ekhand, Jhansi. Admitted on Tuly 30. sulfering from most typical rhinoscleroma, affecting nose. pilate and pharynx. No history of any member of his family ever having suffered from a similar complaint nor has he erer seen the disease in any other person. Three years ago he first noticed a small hard pimple on the skin of the right side of the nose-abnut the middle; at the same time he sufferer from occasional attacks of epistaxis. 'The hemorrhage stopped entirely after six months and has never recurred. The growth slowly but steadily extended until the greater part of his nose became affected, and then involved the upper lip, soft palate and pharynx. Captain Cormwall. I.M.S., isolated the bacillus, from which he made pure cultures and also rhinosclerin, which was tried without success. Large doses of carbolic acid and idoform administered internally proved likewise useless. Partial excision and applications of formalin, and more recently the $x$-rays, have been tried, mnder. which treatment the disease appears to have become stationary.

There are no gynecologists connected with the Madras General Hospital, the attending surgeons being in charge of all surqical cases regardless of sex. The hospital has nine private rooms, for which the paticnts are charged from 2 to 5 rupees a day $(.64$ to $\$ 1.60)$.

Bubonic plagne cases oceasionally find their way to Madras, but the sanitary precantions are so stringent that the disease has never gained a foothold here. Every stranger who arrives at Madras by boat or railway is kept track of by the police for 10 days, the maximum limit of the period of incubation of bubonic plague.

Calcutta. Ixpis, Sept. 17, 1904. 

BENGAL MLDICAL COLLEGE AND CALCLI"I' GOTERNAENT GENERAL HOSPITAL.

The medical interests of Calentta, a city of great commercial importance, with nearly a million of inhabitants. center in the Bengal Mledical College and the Govermment General Hospital; its clinieal department, college and hospital are located on the same spacious grounds artistically laid out, intersected by well-made and well-kept walks and ornamented with trees, shrubbery and flowers. (Fig. 40.) Both institutions are

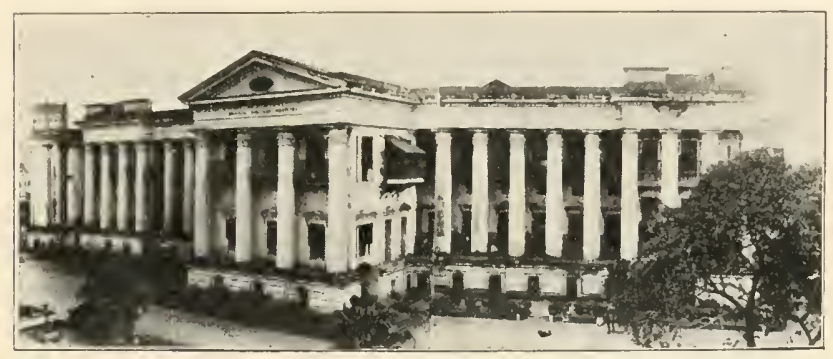

Hig. 40.-Bengal Medical College, Calcutta.

managed by officers of the Indian Medical Service, who constitute the finculty of the college and attending staff of the hospital, thus cementing together the didactic and elinical teashing and uniting them practically under one administration, and securing uniformity in the methods of teaching and a systematic progression of the courses from term to term and year to year.

\section{BENGAL MEDTCAL COLLEGE.}

The Bengal Medical College was founded in 1830 , and from a small beginning has gradually developed into a great medical school with an attendance at the present time of about 600 students. The original structure is an imposing, massire stone building with 
graceful fluted columns and broad stone steps on the side of entrance. The college, as well as the hospital which in reality forms an integral part of it, had to be enlarged from time to time in order to accommodate the rapidly increasing number of students. The requirements for admission and graduation correspond with those of the other medieal colleges of India. Separate laboratory buildings have been erected, well adapted for the purposes for which they are intended and fairly well equipped. The medical classes are rery mueh mixed, not only in nationality and color. but also in the different aims pursued by the students. Thus there are "regular" and "casual" students; the former continne their studies for nive years with a riew of passing the final examinations for the L.MI.S. or MI.B. degree; the latter are permitted to take a partial cour'se of lectures or any department of hospital practice, with the permission of the prineipal of the sehool and the professor, on payment of the fees in advance at the fixed rates.

Then there are special provisions made for female medical students and military pupils. Admission to the female certificate course is granted by the prineipal, provided the student lias passed the preliminary arts examination. Admission to the military pupil course is regulated by the director-general of the Indian Medical Service. I am particularly anxious to define in connection with the Bengal Medical College the status of female medical students in the medical colleges of India. Female students may enter: $a$, As regular students for the university course; $b$, as female certificate students; $c$, as easual students. The preliminary arts examination required before entering is: $a$, The F.A., Calcutta, or its equivalent; $b$, the entrance, or its equivalent; $c$, a student who has entered for the university course may be permitted by the prineipal to change her plans of studies at any stage, and to join the certificate class instead. Female students entering as regular or 
female cortificate students are cligible for a government scholarship, :0 rupees per month, and are not rhalreel any fees.

\section{EEMALE CERTIFICATE CLASS.}

Admission to this class is granted by the principal. 'The number of admissions is determined by him. Students of this class must be over 1 if years of age before commencing their studies. They must have passed a preliminary arts examination before admission to

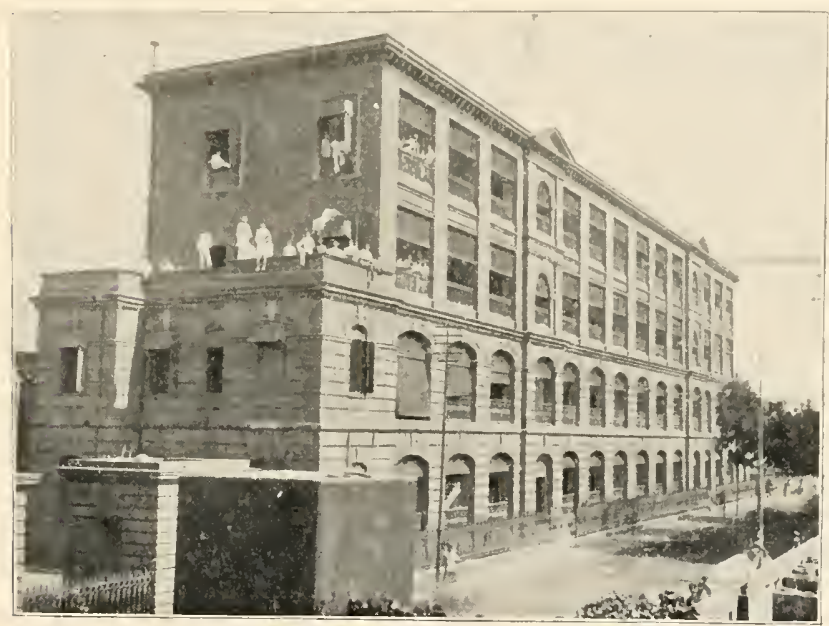

Fig. 41.-Quarters for military pupils.

the college, viz., 1, entrance examination of the Calcutta University or an equivalent; 2, a preliminary arts examination recognized by the British general medical council.

THE SURNOMOYE HOSTEL.

All female students are expected to reside in the hostel, located in the college grounds, and only under exceptional circumstances will they be allowed to live with friends or guardians ontside the college. Applications may. therefore. have to be refused on the ground that there is no accommodation in the hostel. Under 
the rules of the hostel preference is given to native students. While in the hostel students are under the superrision of the lady superintendent and must conform to the rules laid down for their guidance. While within the college precincts students are under the Aisciplinary control of the principal.

MILITARY PUPH CLASS.

The present attendance of Bengal Medical College includes 96 military pupils who, at gorernment expense, are being educated for the subordinate Indian Medical Serrice. These students are in uniform and reside in a separate building across the street from the college (Fig. 41), and besides pursuing their routine stndies, are drilled daily by a retired captain of the Indian army, who at the same time exercises supervision orer them and is responsible for their conduct outside oi the college precincts. The following are the regulations for this class: 1 . The administratice control of this class, as a portion of the Indian subordinate medical department, rest with the director-general of the Indian Medical Serrice. 2. Students are admitted to this class under the orders of the government of India, military department. 3. Students must be of European or Eurasian parentage. physically fit, of good character, and between 16 and 18 rears of age on admission. 4. While at the college they will be styled military pupils. 5. Their education at the college is intended to fit them for employment in hospitals of British troops and in military and civil appointments. 6. The course of study is four years. \%. Military pupils must obtain permision from the principal before attending lectures on subjects outside their curriculum. 8. The periodical and final examinations of the curriculum will be conducted by the faculty, and students who fail to pass them will be dealt with in accordance with the rules laid down in the prospectus issned by the directorgeneral of the Indian Medical Serrice. 9. At the end 
of the conrse military pupils, if reported qualified, will be attested and admitted into the Indlian subordinate medical department. 10. At the same time they will receive a certificate qualifying them to practice physic in India and designate themselves diplomates of the Medical College of Bengal. 11. A military pupil who, at the end of his first year at the college, does not, in the opinion of the prineipal, give promise of proving a successful or desirable student, will be liable to removal. 12 A military pupil, in the event of failing to pass the periodical and final examinations of the curriculum, or misconducting himself, may be summarily remored by the director-general of the Indian Medieal Serrice, and all certificates to which he may otherwise be entitled withheld. 13. A military pupil desirous of relinguishing his studies can do so only with the sanction of the director-general, and on refunding the whole amount of pay received by him. 1t. I military pupil who, after completing the course, declines to be attested, will similarly refund the whole amount of pay received by him, and will not receire any certifieates. 15. The order and discipline of the military pupils is maintained by the superintendent of military pupils and the resident staff, under orders of the principal. 16 . While under instruction in the college or hospitals military pupils are subject to the rules for the maintenance of discipline applicable to other students. $1 \%$. Leave of absence to military pupils is granted by the prineipal. 18. No certificate of attendance on any course of lectures, or practical work. will be granted to a military pupil unless he has passed the entrance examination of the Calcutta miversity, or its equivalent, before commencing the course, and has also paid the fees laid down for casual students.

Female medical students who enter the certificate class contimue their studies for four years and are required to pass a satisfactory examination in the following branches. 
First Iear.-Descriptive and surgical anatomy, general anatomy and phrsiologr, materia medica, elementary chemistry, dissection, practical pharmacy, followed by a test examination in anatomy, physiology, materia medica and chemistry.

Second Tear-Descriptire and surgical anatomy, general anatomy and physiology, materia medica, chemistry (full course), dissections (six postmortems), nine months' hospital practice, three months' out-patient practice. to be followed by a final examination in anatomy, phrsiology, materia medica, and chemistry.

Third Icar-_Medicine and clinical medicine, surgery and clinical surgery, midwifery, medical jurisprudence. pathology, practical midwifery (three labors), ophthalmic medicine and surgery, six postmortems, nine months hospital practice, three months: ophthalmic hospital practice, to be followed by final examination in pathology and medical jurisprudence.

Fourth Year.-Medicine and clinical medicine, surgery and clinical surgery, midwifery, practical midwifery (six cases of labor), three months' hospital practice. midwifery wards (six months), dental outpatient practice (three months), dental surgery (optional), to be followed by final examinations in medicine and surgery and midwifery.

It will be seen from the above that in the whole curriculum there is only one optional branch-dental surgery. The English teachers of medicine and surgery beliere in the wisdom of making the attendance on all lectures and clinies obligatory, as it shonld be. Some of our best American medical colleges are making a serious mistake in giving the students too much. liberty in the choice of their studies, the results of which must necessarily be a fragmentary and imperfect knowledge in some of the most important branches they are expected to master. Optional liberties in a medical college are as harmful as they would he if they were introduced into our primary schools. Students thus priv- 
ilewerl will only learn enough of the branches that are di-tasteful to fhem to squeeze through the final examinations and no nore. Optional studies are in place in post-graduate elucation. but should not he countenancer in a medical college whose function it is to instruct the students systematically and thoroughly in all branches pertaining to medicine and surgery.

The Bengal Medical College has mulertaken the erluation of midwives. a very commendable extension of its wirle ficld of usefulness.

\section{MIDWIVES AND DIAS.}

The regulations for this department are formulated muler this heading:

IIomen who have a fair knowledge of English, but who have not passed the entrance examination or its equivalents, will be admitted into the Eden Hospital to learn midwifery. The gorernment grants 20 rupees $(\$ 6.40)$ a month toward the board, washing. etc. of each pupil and gives them free quarters. After a year's tuition and bedside practice, if found proficient. they will obtain a certificate qualifying them to practice midwifery. The fee for each certificate is 5 rupees (\$1.60). They are expected to do general nursing in the wards as well as midwifery. Women who have not pased the entrance examination or its equivalents, but who can read and write Bengali, can be admitted into the Eden Hospital as pupil dais. The gorermment grants 6 rupees $(\$ 1.92)$ each month to eight pupils tomard their board, washing, etc., and gives them free quarters. After twelve months' tuition and bedside practice, if found profieient, they will obtain a certificate qualifying them to practice midwifery. They are expected to do nursing in the wards as well as midwifery. The edncation of these two classes of midwives for country and village practice must meet a pressing

* need, as in many remote parts of India medical aid is ton remote to be available in obstetrical cases. These 
women can be made also very useful to physicians and patients as nurses in grave cases of illness or accident.

Major F. J. Drury, I.MI.S., is principal of the college, and Professor Bird occupies the chair of surgery.

\section{CALCUTTA GOFERNAIENT GENERAL HOSPITAL.}

The Calcutta Gorernment General Hospital is rirtually the clinical part of the Bengal Medical College. The different parilions and laboratories form a group of buildings of which any city and country might well be prond. The Eden Hospital (Fig. 42), a separate, new modern building, is the maternity in which about 600 women are delivered every year. The strictest cleanlines prevails throughout this building and sepsis in in-patients is almost unknown. The woman in labor is prepared with the same care as for a major operation, and ererything brought in contact with her during the delivery and lying-in period is carefully disinfected (hands) and sterilized (dressings). The delivery room has all the aspects of an operating room. Three tables are always kept in readiness. Mother and child remain in the lospital from ten to fourteen days after delivery. The Ezra ward, with forty beds. the gift of a rich Jew, is for the exclusive use of Jers. The original hospital building is an old-fashioned twostory solid stone building which in the light of morlern improvements would appear somewhat antiquated if it were not for the electric lighting and electric punkah motor. The latter is kept in motion night anil day during the hot season and is a source of immense comfort to the patients. The hospital can accommodate 450 patients and has a few private rooms for which a charge of 22 rupees ( $6 t$ cents) a day is made. The operating room has a small amphitheater which affords standing room for the students, but lacks many of the conreniences and appliances considered at the present time so essential for aseptic surgical work. As in all hospitals in India. chloroform is the favorite anesthetic 


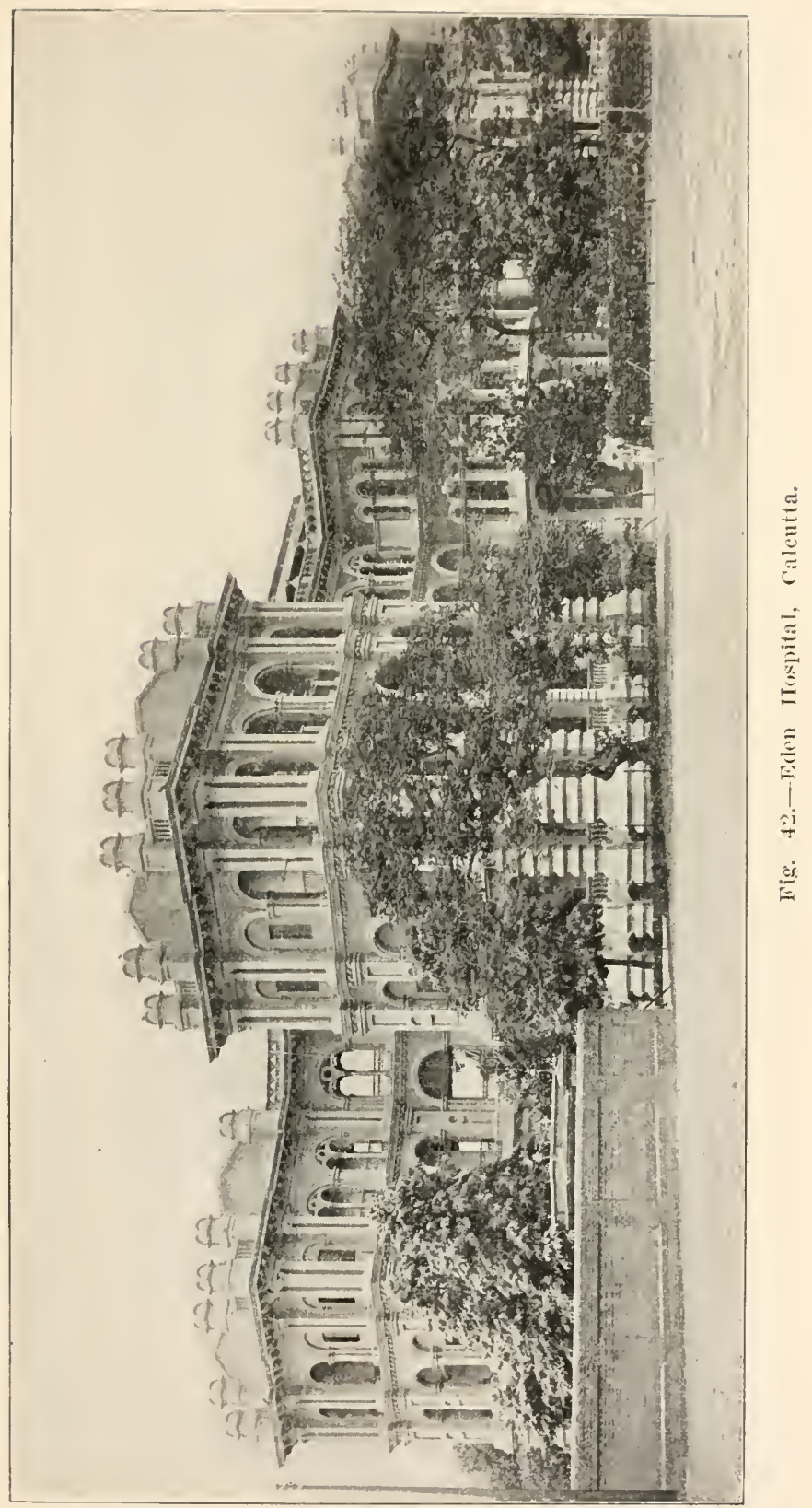



and the biniodid of meremry takes the first place as an antiseptic. Buried sutures have been abandoned almost "ntirely and the removable silk and silkwormgut sutures are in genesal woe. The nursing is in charese

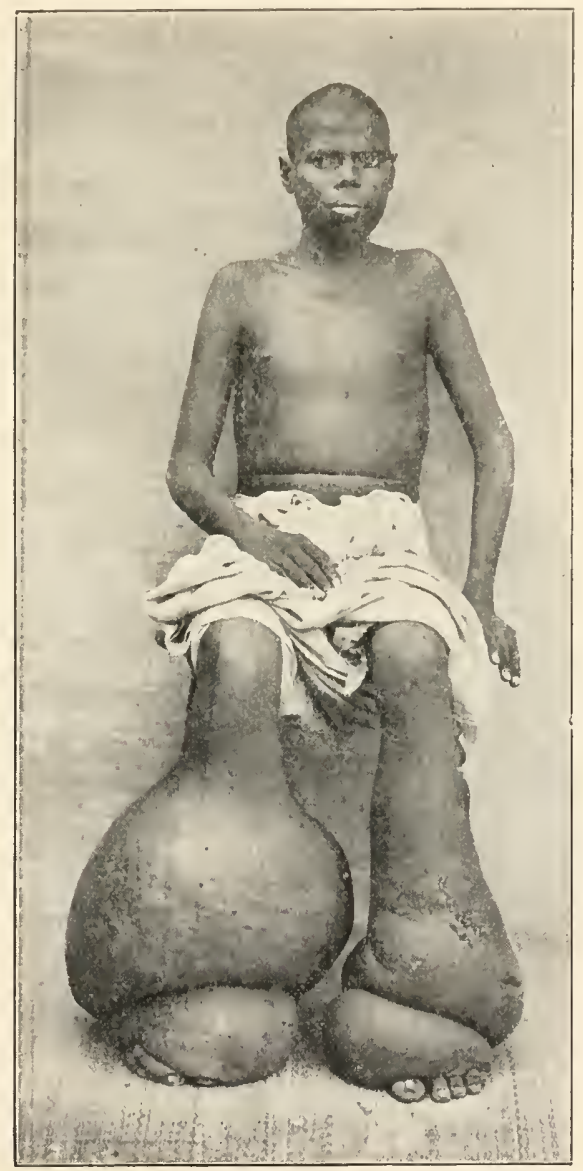

Fig. 43.-EIephanthiasis of legs. By courtesy of Capt. Rogers, I.MI.S.

of two Anglican sisters, who are also at the head of a recently organized training school for female nurses, which has now an attendance of forty pupils. Male and female ward attendants assist the nurses in their 
work. The pupil nurses are Europeans or Eurasians and remain for only one year in training.

Among the more interesting cases Professor Bird showed me fire patients recently operated on for abscess of the liver. All were doing well, although greatly emaciated from the effects of the disease. Abscess of the liver appears to be extremely common in this part of India, as Professor Bird not long ago operated on trrenty cases in two months. Carcinoma in all its form: is met with here with about the same frequency as in Europe. Acute osteomyelitis and surgical tuberculosis. on the other hand. are comparatively rare. Srphilis and gonorrhea are rery common, but in the mative both of these diseases pursue a benign course. Enlargement of the prostrate gland in the aged natives is very rare. This statement is confirmed by all surgeons I met in India. They can offer no explanation for this. but there must be something in their habits or mamner of liring that protects them against this curse of adranced life so common among Europeans and Americans. Stone in the bladder is very common. but comparatively few of these cases enter the hospital. as they are operated on by physicians who practice in the country districts, the operation being re. garded by them as a safe and easy one.

A chronic parenchymatons inflammation of the mammary gland in young men is of frequent occurrence here and is usually treated by excision. Cystitis is rery rare as compared with our hospital experience. Two reasons might be adranced to explain this: the rarity of prostatic hypertrophy in India and the very mild course gonorrhea pursues in the natives.

Profesor Quicke. of Bombay. made the statement to me that he nerer knew of a rajah to enter on a cath. eter life. Tuberenlosis of the kidney and bladder is also infinitely more rare in India than in our country. As is the case with all colored races, the natives of India are rery subject to benign tumors, especially fibro- 
ma, keloid, lipona, papilloma and cystoma. (On the other land, alfections of the reins, hemorrhoids, varicocele and varicose reins of the lower extremitics, are not nearly as frequent as with us. Among the thousands of barelegged men I saw in India I did not observe a single instance of well-marked varicosity and, consid-

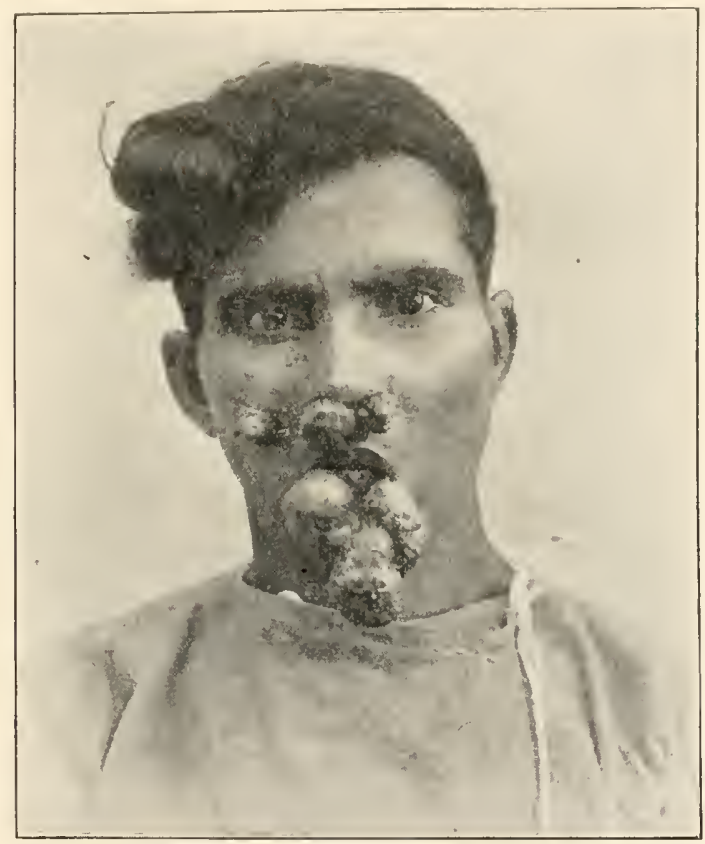

Fig. 44.-An undiagnosed case. By courtesy of Capt. Roger's, I.M.S. ering the enormous clinical material that passes through the large hospitals, the number of operations for hemorrhoids and varicocele is astonishingly small. Tuxative regetable diet, active exercises. absence of tendency to obesity and looseness or absence of dress will go far to explain the comparative freedom from ectatic discase of the hemorrhoidal, spermatic and saphenous reins, a suggestion which might be of some serrice to our numerons sufferers from plethora, obesity and stagnant venons circulation. 
In the melical wards I fomd bere, as in all hospitals in Inilia. the greatest variety of malaria and its multitude of compications. A large part of the hospital space is oceupied by malarial patients and the physicians here have an excellent opportmity throughout the entire rear to study malaria in all its endles clinical and pathologic aspects.

IThat an excellent place Bombay or Calcutta would be for a great school for the study of tropical disrase-: The material is here, and not in London nor Lirerpool. and if ntilized to greatest adrantage it must be studied here and not thousands of miles away from where the diseases had their origin.

Typhoid ferer is not so common as we would suspect after an inspection of the water supply and insanitary enviromments of the masses of the natives. The naive prefers to draw his water from the well that has serverl his ancestors for centuries rather than from the tap of the modern water-works. If it is at all within reach. water from the sacred. Ganges is his farorite drink. Most of the cases of trphoid ferer I examined in the different hospitals of India were of a mild trpe, and the mortality from this disease as published in the hospital reports is not great.

India has its share of pulmonary tuberculosis. lut for reasons that can not be explained tuberenlosis of bones and joints is very rare as compared with the frequency with which this discase attacks our childhood population. In any of our large hospitals we see ten cases of joint and bone tubereulosis to one in the hospitals of India, and on the streets of Chicago ten cripples from this disease to one in India. The same remarks apply to tubereulosis of the lymphatic glands and genito-urinary organs. Diarrhea. dysentery and malaria are the preraing diseases of India and it is these affections that tax most hearily the therapentic resources of the physicians, both in hospital and private practice. In this as well as in all clinical hospitols of India. much stress 
is placed on the practical training of the student-; nore aspecially by bedside in-truction. 'The out-pationt department is ntilized to the greatest adrantage and it is lere that the students are given the very best oplortunities to come in tonch with the patients. Under the smpervision and guidance of the professors or eonpetent instructors, they are refuired to make thorough clinical examinations, apply dressings and assist in the operative work, and the last year students are privileged to perform some of the minor operations.

The arerage mudical student in India has a livener taste for practical work than for scicntific research. and consequently makes good use of his elinical opportunities. The female medical students are no exception to this rule, although it is generally adnitted that at the end of the eurriculum, in consequence of a more diligent attendance on the didactic lectures and a more liberal use of midnight oil in reading their text-books, they are ahead of their male colleagnes in the theoretical knowledge of medicine. The male students are rery fond of all kinds of athletic sports, and the time spent by them in dereloping their phrsical strength is made use of by the women in committing to memory the contents of their text-books. Then, too, the roung men spend more time in amusements when away from the plargrounds and out of the hospital and lecture-rooms than the young women. who have less resire in this $\mathrm{li}$ rection and are kept nnder stricter supervision.

If I had any criticisn to offer in the nethods of teaching clinieal surgery in India I would say that the clinical material and specimens obtained by operations and postmortems are not made use of to the greatest adrantage for the benefit of the students. Pathology should be made the most important feature in the teaching of surgery as well as of medicine. In defense of this apparent neglect it must be said that the clinical teachers in some of the colleges are withont the 
necessary appliances and equipments to give surgical pathology the prominence it so well deserves.

It was in the pathologic laboratory of the Bengal Medical College that I was given an opportunity to examine a new parasite, the Piroplasma donovani, through the courtesy of the director of the laboratory, Capt. Seward Rogers. T.M.S. He was also kind enough to furnish me with several mounted slides containing this parasite so recently discovered by Leishman and Donovan. In another place I will give a more detailed account of this parasite, history of its discorery and etiologic relationship to splenic anemia. Medical science is much indebted to the researches of the members of this corps. many of whom are indefatigable workers in a climate well calculated to undermine physical strength and paralyze mental activity.

Port Said, Egrpt, Sept. 26, 1904. 


\section{THE CITY OF JAIPUR, INDLA, AND IIAYO HOSPITAL.}

Jaipur is one of the largest, most important and interesting inland cities of India. It is the local seat of government of the state of Jaipur and the residence of the maharajah, whose palace, extensive gardens, crocodile tank, state and prirate carriages and elephant stables are objects of growing interest to every visitor.

The city proper is enelosed by towering walls and the two gates are closed and locked regularly at 10 o'clock every evening, in the same manner as was done 300 years ago, when they were first opened during the feudal times, to serve as a safeguard against nightly invasions. This old eustom continues with great punetuality, although the protection for safety of life and property has become superfluous since the strong arm of the English government has done away with internal strife and has made India secure against invasion from without.

Jaipur has taken the place of the ancient eapital city Amer, a mountain stronghold seven miles distant, once a great and prosperous eity, now deserted and its great palace and former mansions and ramparts crumbling into dust. A great fort on the highest mountain ridge orerlooking the ancient palace and depopulated eity is kept in good repair and is occupied by a regiment of native troops. Looking at this great city, now in ruins, centuries ago the power and pride of this part of India. the safe refuge of a large and prosperous population, the seat of a gay and powerful nobility, we are strongly reminded of the signifieance of:

\footnotetext{
"The fashions of human affairs are short and changeable and fortune never remains long indulgent to men."-Quintus Curtius Rufus.
}

A few coolies and numerous monkeys make up the 
scanty population of the abandoned capital city which centuries ago was the seat of political power, fashion. wealth and general prosperity.

In the meantime its rival, Jaipur, has become old. The present population of Jaipur is about 85.000 ; the principal streets are wirle, linerl by lonses three and

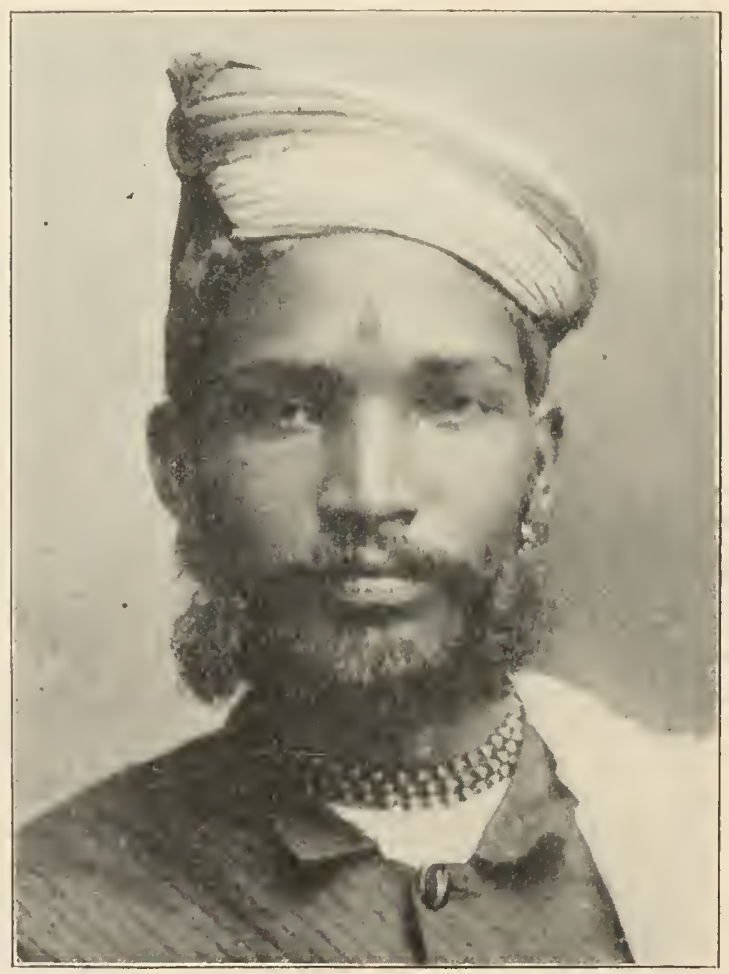

Fig. 45.-Native of Jaipur.

four stories high. with walls covered with plaster, painted a light miform roseate hue, ornamented with rude artistic designs in white, representing plants and flowrrs. 'This is the place to see the real types of natives (Fig. 45), their habits and customs maffected by time and European influence. 


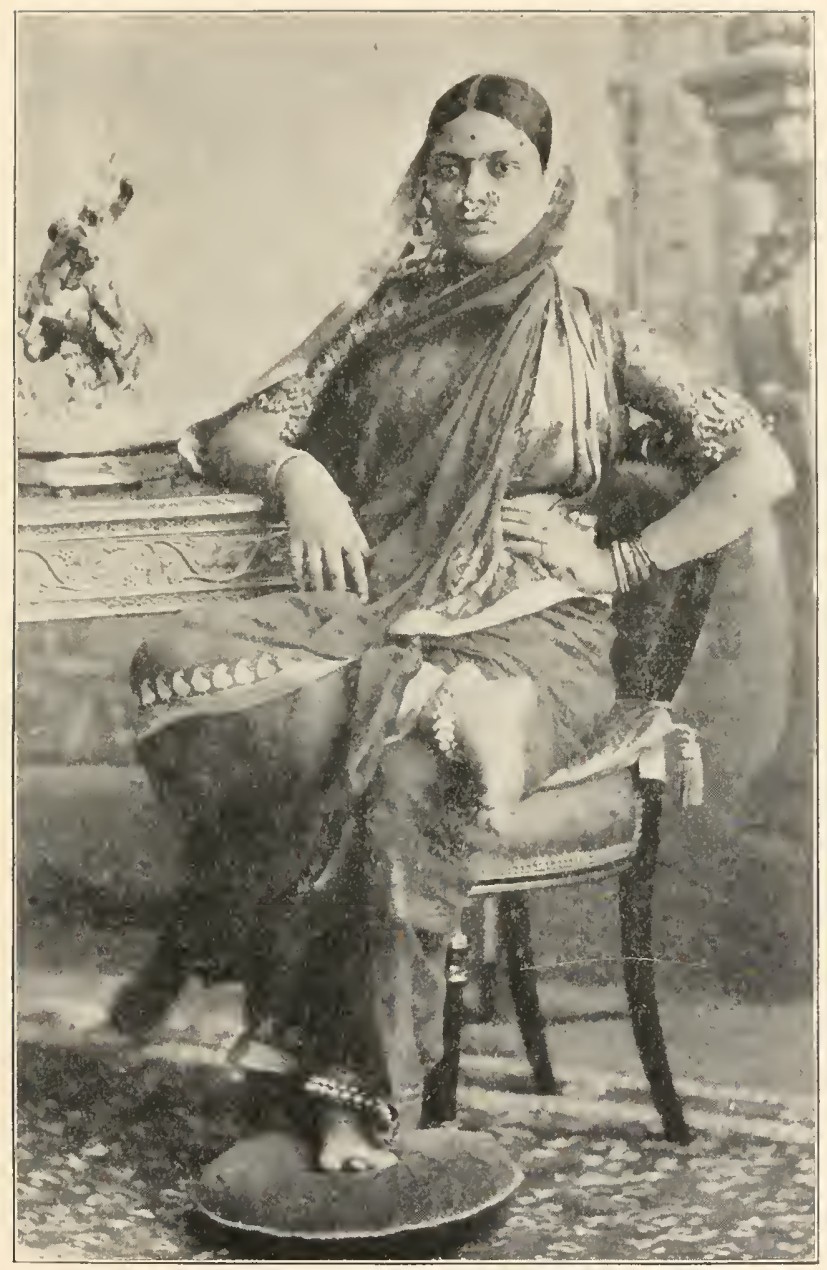

Fig. 46.-IIndu dancing gir]. 

Agriculture, gardening and the difierent industries are conducted in the same manner now as they were a thousand and more years ago. 'The elephant, came], donkey and buflalo are the beasts of burden now as then, and are trained and used in the same manner as under the masters of centuries ago. 'The little open shops and colners, where the artisans do their work with the erudest kind of tools, are the same now as they were when first opened for business, hundreds of generations ago.

This is the place to see Hindu feasts and processions in their original form. The Hindu, above any other people, is proud of his race, his ancestry and ancient civilization, and is deeply. almost hopelessly, rooted in the teachings and faith of his Brahmin religion. Hindu life, habits and customs as seen in Jaipur illustrate the meaning of :

\footnotetext{
"So difficult is it to bring people to approve of any alteration of ancient customs; they are always maturally disposed to adhere to old practices unless experience evidently proves their inexpediency."-Livius.
}

The greatest trouble with the Hindu is to convince him of the inexpediency of anything inaugurated by his ancestors, as he is a firm believer in their infallibility concerning happiness in life and an ascending scale of blessedness in the hereafter.

Jaipur represents the center of one of the most fertile and prosperous agricultural states in India. Indications of considerable local wealth in the city are not lacking. The reigning maharajals is very popular and is well and farorably known for his many unostentatious works of charity. It was this prince who, during the last long famine, kept hundreds of his poor subjects from starving by his liberal contributions of food and money. He is a friend of the poor and takes a paternal interest in the Mayo Hospital.

Medical affairs in the eity and state of Jaipur are managed by P. Durrel Pank, Lieutenant Colonel, I.M.S. 
His last official report ${ }^{1}$ contains many interesting facts, and from it I have gleaned much valuable information.

In speaking of the temperature and rainfall he says: "The mean temperature was $7 \% .7 \mathrm{~F}$., or $0.9 \mathrm{~F}$. above the arerage; the maximum temperature was $115.20 \mathrm{~F}$., on June 3 and 12, and the minimum 35 F. on December $2 \%$ : the amplitude of yearly fluctuation was $80.2 \mathrm{~F}$., and the greatest on any day was 41.4 F., on February 9. The rainfall registered at the Jaipur Observatory was 23.39 inches, or $1.0 \%$ below the yearly average."

The vital statistics show that during the year 1903 the number of births recorded was 4,436, against 6,641 deaths, the death rate being much larger than the birth rate. Infantile mortality is responsible for the large death rate, as the number of deaths among children under one and fire years, during the same time reached the astonishing figure of 3,863 . The three months most fatal to child life were: June, 531; October, 461, and September, 459. During the year there were 58 deaths from smallpox, 244 from measles, $y$ from cholera and $\%$ from imported plague in Jaipur city.

In reference to the steps taken to check the cholera epidemic the report states: "The usual necessary precautions were taken in every village and city where the outbreak of cholera took place-wells were disinfected with permanganate of potassium; insanitary conditions in the villages and towns removed, so far as possible, and hospital assistants with proper medicines were dispatched to treat all cases."

Malarial fevers were prevalent in many districts in the autumn and 236 packets, containing 100 doses of quinin in each. were supplied to officials of the government for free distribution to the people; there was also a free distribution of quinin and other cinchona alkaloids from each of the district dispensaries.

The mortality from malaria was low, owing undoubt-

1. Annual Report on the Jaipur Medical and Meteorological Institute for 1903. 
edly to the liberal distribution of quinin free of cost through the dilferent branches of the government service. Free vaccination is performed on a very large scale, 84,019 cases during the year covered by the report. A very interesting account is given of the experience of the medical officers in carrying out the prophylactic serum treatment (Haffkinc) during the epidemic of bubonic plague, and the prejudice of the people against this measure was only overcome by the noble example of one of their chiefs.

"In regard to inoculation, the adoption of this in the early days of the epidemic was most difficult and at one time apparently hopeless; but patience, tact and moral sausion at last overcame the dense ignorance and stupid prejudices of the villagers. The last argument, and that which really compelled them to give way in the end, was the fact that their nazim stripped and bared his body before their eyes in order to be inoculated as an object lesson. This they would not allow, and rather than that he should be a scapegoat in their behalf, a few consented. 'The plunge was made and all followed suit; before many had been inoculated others clamored to be inoculated at once as they could not afford to rum the risk of delay in waiting to be done in their proper order and turn, and protested against others being inoculated before themselves. When once they saw and believed that no harm and little inconvenience followed the inoculation, they implicitly believed in it and attributed to it many virtues which it does not possess nor lay claim to." What a striking illustration of

"Men are but children of a larger growth."Dryden.

\section{MAYO HOSPITAL.}

The Mayo Hospital, so called in memory of a former governor of this part of India, is the government general hospital of Jaipur and is the largest of the twentysix hospitals and dispensaries in the state of Jaipur. 
It has a superb location, the buildings and grounds facing the beautiful botanical garden and the fine statue of the governor whose name it commemorates. The main building is a solid two-story stone building, and there are a number of one-story parilions of the same material, connected by roofed cement walks with the central building. The hospital has accommodations for 160 patients, all natives, cared for at gorernment expense. The wards are capacious, well lighted and rentilated, but the furniture is scanty and of the simplest kind. The operating room is small and the applianees for asepsis of a somemhat primitive character. Lient.-Col. Pank is at the head of the medieal staff, assisted by sereral assistant surgeons of the subordinate Indian Medical Serrice.

The worst feature of this hospital is a lack of an adequate number of trained female nurses. Most of the nursing is done by male and female ward attendants, who receire at best only the most elementary training and, consequently, can not be relied on in the operating room or in the care of grave surgical and medical cases. A training school for female nurses is a desideratum that should be met without any further loss of time, as it would be the means of greatly facilitating the work of the medical officers and wonld secure more efficient eare for the patients afflicted with grave disease and for those who are subjected to operative treatment. The records of the hospital speak well for the surgical rrork of Lieut.-Col. Pank, who does most of the operative work. which includes general surgery, grnecology and ophthalmology. Considering the difficulties he has to contend with. his results compare well with those of other surgeons in India who have better assistance at their disposal and whose patients are under the care of competent trained female nurses.

During the year 1903, 24,648 ont-patients and 2,124 in-patients. total 26,7\%2. were treated at the Mayo Hospital. During the same rear 696 major and 664 
minor, total 1,360, operations were performerl; of these 21 per cent. were on women. Five ovarian cysts were removed by orariotomy without a death-two of these cysts were very large and in three cases the adhesions were extensive. Ten successful operations for tuberculosis of the lymphatic glands in the neck, axilla or groin were performed and were in many cases very extensive, entailing long and careful discections. 'Thirtyseren operations on bones were made without mortality. Among these were two cases in which the whole lower jaw was removed on account of an enormous epulis; and in three cases partial excision of this bone, in one case for sarcoma and in two for necrosis. The right upper maxilla with malar and nasal bones, was remored for sarcoma. No death in ten amputations of all kinds. Operations on the eye constitute the bulk of the operative cases. Lieut.-Col. Pank has had an enormous experience in operations for cataract.

During the year mentioned above 239 cataract operations by von Graefe's method were performed, 219 by Lient.-Col. Pank and 20 by Assistant-Surgeon Daljaag Singh. These operations were performed on 199 persons; 224 were recorded as able to see well, 4 discharged otherwise and 11 were under treatment at the end of the year. Artificial pupils for corneal opacity were made in 5 cases, in 3 persons, and all were useful in increasing vision. Iridectomy for glaucoma was performed in 14 cases and the disorganized eyeball was extirpated in 14 cases. Eight operations for the radical cure of inguinal hernia by Bassini's method were successful. In four of these cases the hernia was congenital.

'The rectum and anus were operated on 31 times with one death (anal fistula): 14 times for hemorrhoids by ligature and 8 times for anal fistula. Tesical calculi were removed in 43 cases by litholapaxy with no death; in 3 cases by lateral lithotomy with one death, and in 4 cases of perineal lithotrity with no death. All patients 
treated by litholapaxy made excellent and speedy recoreries. The largest stone removed by this operation weighed 935 grains and the average hospital life for each case was 4.18 days. 'The 3 cases operated on by lithotomy were unfit for any other operation, and the patient who died after operation was a man worn out by the disease complicated by cystitis and renal trouble; his stone weighed 1.072 grains. Perineal lithotrity was reserved for cases in which a lithotrite large enough to crush the stone could not be passed by the urethra. The operation was performed by making, on a small staff, a median incision just large enough to permit a sufficiently large lithotrite to enter the bladder, one direct stabbing incision going straight into the bladder on a grooved staff. was sufficient. The largest stone weighed 1.501 .5 grains and the average stay in the hospital was 12.5 days.

\section{SPIENIC ANEIIIA.}

In the medical wards of this hospital I had an opportunity to examine four cases of so-called splenic ancmia, that is, a disease characterized by great enlargement of the spleen with progressive anemia. All the patients were young men, natives, from 18 to 35 years of age. In all the abdomen was very much enlarged and pendulous, and through the thin abdominal walls the outlines of the enormonsly enlarged spleen could be very plainly traced. In some of these cases the spleen extended beyond the median line and its lower border almost reached the level of Poupart's ligament. In two of the cases the liver was also markedly enlarged. Emaciation and a profound anemia in all of them were the most prominent clinical features. I was informed that this disease generally yields in the course of time to a sulphate mixture which is used in this hospital, of which the most active ingredients are sulphate of quinin and sulphate of iron.

During my visit to the Bengal Medical College, Cal- 
cutta, Capt. Seward Rogers, I.M.S., professor of piathology, was kind enough to show me under the nicroscope the parasite which has been shown to be the cause of this strange discase. It was discovered by Leishman and Donovan. and has been classified by Lareran and Mesnil nuder the name of

\section{PIROPLASMA DONOVANI.}

This newly discovered parasite has attracted a great deal of attention, and among the numerous articles descriptive of it I will only refer to the article on Piroplasmosis by Captain Donovan, published in the ". Annual Report and Statistics of the Government General Hospital Madras, for the Year 1903." Ind a verr important monograph. "A Preliminary Report on a Parasite Found in Persons Suffering from Enlargement of the Spleen in India," by Lient. S. R. Christophers, M.B., I.S.MI., a government publication.

Captain Donovan, in the article referred to, gives a short history of his discovery, from which I will give here some extracts. In speaking of piroplasmosis he says: "Tnder this head I have classified a new disease prevalent in Madras; the symptoms are those of socalled chronic malaria. . . . I had noticed many cases of chronic irregular pyrexia, with enlargement of the spleen, and occasionally of the liver, bronchitis, edema of the feet, subcutaneous hemorrhages, chiefly of the petechial type, diarrhea of a dysenteric natmre and cancrum oris. The treatment was most msatisfactory, no drug having the least beneficial effect."

Captain Donovan doubted the malarial character of the disease and at once made a thorough examination of postmortem specimens. "With a view to remore this doubt I attended the postmortems and took smears of blood from the spleens of patients said to have died of chronic malaria. On the first day, April 9, 1903, I found, in a slide containing such a smear, numerous peculiar round and oval ring-like little bodies, with 
two masses of chromatin situated in opposite poles. Convinced as I was of their parasitic nature, I could not. however, refer them to any group of protozoa. I thought I had discovered the long-sought-for resting stage form of the malarial parasite in man, but on perceiving the same bodies in two other cases on April 23 and 24, 1903, I changed my view and considered that they might be postmortem degenerations of the nuclei of the splenic pulp cells. On June 15, 1903, I receired the British Medical Journal of May 30, of the same rear. and in it, on page 1,252 , was an account by Major Leishman. R.A.M.C., of organisms identieal with mine. I at once recognized the similarity of what Leishman called degenerations of the trypanosomata, to the bodies found by me in the spleen blood of the three cadarers above mentioned."

On Jime 1\%. 1903, Captain Donovan punctured the spleen of a boy suffering from this type of fever and found in it bodies identical with those found postmortem. The results of this examination were pullished in the British Medical Journal, July 12, the same year. On September 23 he sent a slide containing these bodies to the Pasteur Institute, where they were carefully examined by Laveran and Mesnil and named in honor of their discoverer Piroplasma donovani.

A large clinical experience has demonstrated the direct etiologic relationship of this parasite with the splenic affection in question. The parasite is not found in the peripheral blood and, for diagnostic purposes, blood has to be obtained from the spleen by puncturing it. It is in this organ that the micro-organism is found in greatest abundance. Puncture of the spleen for diagnostic purposes is not entirely devoid of danger; there is, at least, one case on record in which the puncture gave rise to fatal internal hemorrhage (Donovan, Case 24). The presence of this parasite in the splenic blood furnishes absolute proof of the nature of the splenic enlargement and settles the differential diagno- 
sis between this disease and malarial and leukemic enlargement of the spleen. In the paper quoted above Captain Donovan gives a detailed account of 31 casethat came under his personal observation during one year with many postmortem findings.

('aptain Donoran describes the clinical features of this riscase as follows: "The symptoms are, in typical cases, an irregular pyrexia of two or three months' duration, accompanied with shivering with apyrexial intervals. Abont this time the spleen becomes enlarged and painful, and edema of the feet begins; there is wsually diarrhea of a dysenteric nature, which comes and goes for a weck or so at a time. Later the lungs are affected; there is cough and expectoration, enlargement of the liver, ascites (unusual); subcutaneous hemorrhages of a petechial nature; soreness of the mouth, gums or hard palate and cancrum oris. Narked emaciation and anemia supervene, the skin becomes dry and furfuraceous and. if the patient is not washed, the skin takes on a dark discoloration. . . . The blood examination, in cases of piroplasma infection, always shows a marked decrease of the red globules; these vary from two to three millions to the cubic millimeter. There is no actual increase of the leucocytes, but a relaive one of the mononuclears, as in malaria. The urine usually contains albumin and invariably pigment, urobilin. The feces in some cases contain balantidia, ankylostoma and rhabdonemata. Quinin has been given by mouth, hypodermically and intramuscularly ad nauseam, with no appreciable result. The same may be said of other less suitable drugs, i. e., arsenic, salicylate of sodium, carbolic acid, etc."

I will give here as an illustration the findings of only one pastmortem examination: "Case 30. Raghavan, aged 30 years, lived at Periyamett. Fever irregularly for a month and a half; spleen enlargement noticed a month ago; during this period he had occasional attacks of diarrhea and soreness of the mouth. Admitted for 
diarrhea and distension of the abdomen; his spleen and liver were enlarged and he had edema of the feet. He died on the fourth day after admission. 'The postmortem was made by Captain Symons, I.M.S., and the following notes were recorded: Considerable amount of clear fluid with floating lymph in abdomen; colon at splenic flexure gangrenous; transverse colon much thickened-almost half an inch in places and ulcerated. containing raised papillæ on the mucous surface of a bright red color; descending colon a dark gray color: spleen much enlarged with pigment in patches; liver much enlarged."

The Piroplasma donovani is found free in the splenic blood and as a cell inclusion in the red corpuscles and macrophages, but more frequently in the leucocytes; in some of the cells it is multiple. (Christophers.) (Fig. $4 \%$ )

Iient. S. R. Christophers, in his exhaustive monograph on this parasite, gives a rery minnte description of its morphology and multiplication by fission. " - In films stained by Romanowsky's method the bodies are seen with great clearness. They exhibit a renarkable uniformity in size and appearance. The majority are about 2.5 micromillimeters in diameter, but forms may be found which are a little larger, 3 to 3.5 micromillimeters, or a little smaller. Very occasionally still smaller bodies, 1.5 micromilimeters in diameter, may be encomntered. Most of the bodies are approximately circular in ontline, but very many, especially the larger forms, are irregularly oval and very much resemble a cockle-shell in shape. This, indeed, appears to be the most typical shape, and even in the apparently rom forms an approach to this shape can be made out. Occasionally specimens are found more elongated and distinctly pear-shaped. . . . Except in very rare small forms which show only a single chromatin mass, the bodies invariably possess two chromatin masses - a large 


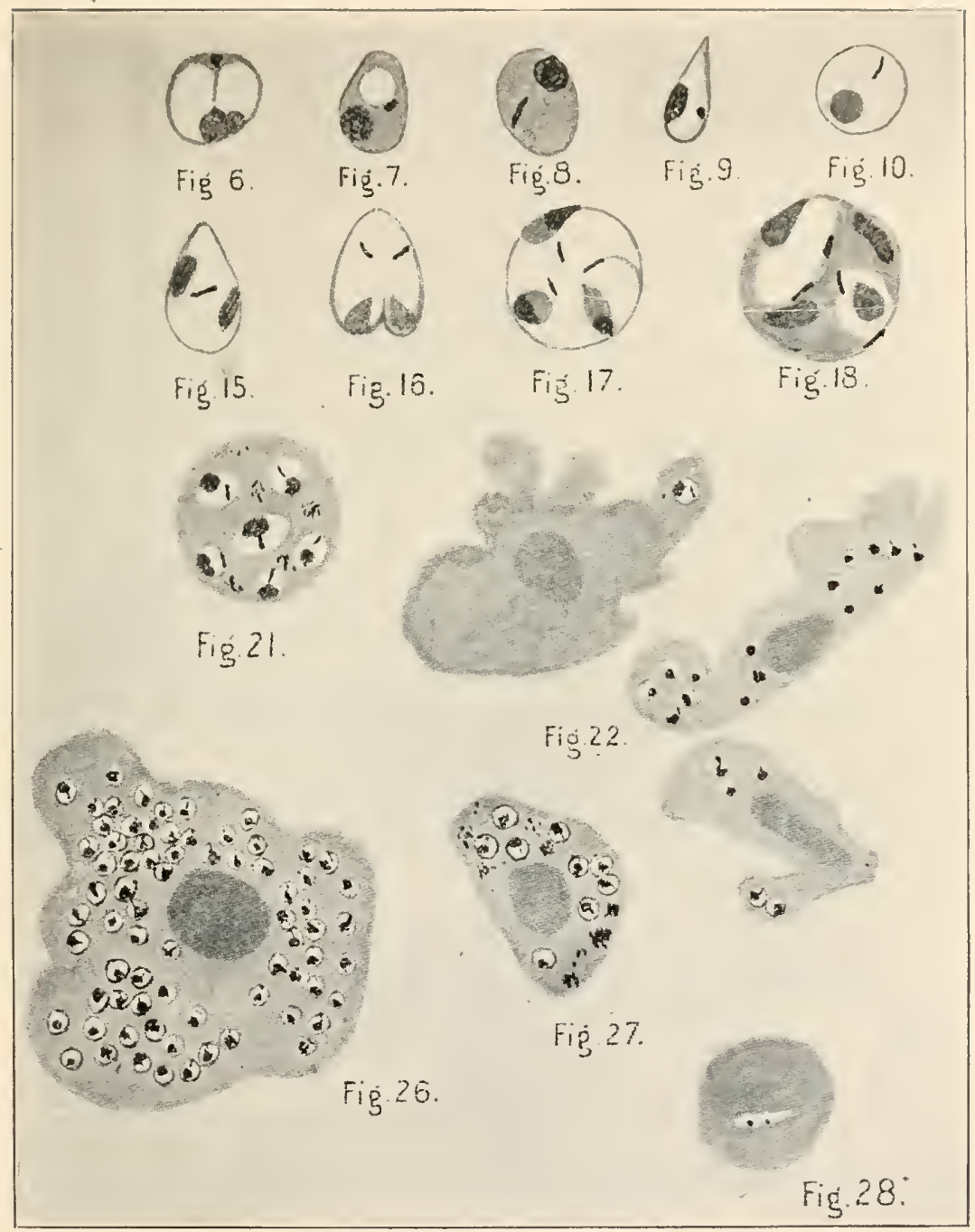

Fig. 47.-Piroplasma Tonovani. 

one staining lightly and a small one staining intensely, with the red coloring matter of Romanowsky's stain.

"The two chromatin masses are usually situated opposite to each other in the shorter axis of the parasite. - . The large chromatin mass is situated near what would be the hinge in the cockle-shell-shaped forms and in the thicker end of the pear-shaped forms. The body substance nsually stains pink by the method cmployed (fixation in alcohol and staining by watery solutions of eosin and Romanowsy's blue).

Fol'ms may be seen which appear to show division of the bodies into two. Appearances showing both longitudinal and transverse fission are seen. In the former two pear-shaped bodies are found lying side by side. The larger chromatin masses are situated in the thick end of the pear and the small red bodies at the thinner end, and the small chromatin mass may often be seen mdivided when the larger masses are widely separated."

The discovery of the real parasitic cause of splenic enlargement and anemia, such a common and very fatal discase in India. will, it is to be hoped, soon lead the way to a more successful treatment.

The work done in this, one of the newest fields in pathology and bacteriology, by the officers of the Indian Medical Service reflects great credit on that branch of the British colonial service and will undoubtedly serve as a stimulant to others to blaze new pathways in the as yet but imperfectly explored wilderness of tropic diseases, tropic medicine and tropic surgery.

Brixdisi, Italy, Sept. 30, 1904. 

GRANT MEDICAL COLLEGE AND THE HOSPl'IAIS OF BOMBAY.

Bombay, witl its 800,000 inhabitants. is the commercial metropolis and medical center of India. The city has many and varied medical institutions that awaken the interest of the professional visitor. The most important among these is the Grant Medical College. the largest medical school in India. For sixty years it has been the Mecca for native young men in that part of India who were desirous of entering the ranks of the medical profession. Thousands of graduates have left its doors well prepared to serve their countrymen as reliable and competent physicians. From a modest beginning it has developed into a great medical school with an attendance of more than 600 . The personnel of the students is an interesting one. The mixture of colors, from the almost pure white of some of the Eurasians to the coal black of some of the Hindus, and the variety in dress, from Parisian to the most picturesque costumes makes up an interesting picture for the foreigner.

The Mohammedan population of India is large but, as a rule, its young men manifest little desire for a higher education and the number of medical students from this source is small. On the other hand, the Hindus take kindly to the professions of law and medicine and the bulk of the medical students is recruited from the high caste Hindus. The Parsee element of the population is well represented in the medical schools, and the strange headdress of the males of these people figures conspicuously in all the classrooms. (Fig. 48.)

The female medical students number about sixty and, with the exception of two or three white women, they are Hindus, Parsees and Eurasians. What are known 
as halt-cases in Ceylon are designated in India by the more euphonious word, Eurasians, meaning a mixture of Europeans with Asiatics. The female medical students have won for themselves here, as elsewhere, an enviable reputation as enthusiastic, hard workers, who, when the time for graduation comes, are never found at the undesirable end of the class. Their subsequent professional career is often, however, a very checkered one. Some receive hospital positions with small salaries, rupees 100 to .200 ( $\$ 32$ to $\$ 64$ ) a month; others enter private practice, but seldom meet with great success; some marry, and not a small percentage sooner or later abandon their profession and turn their attention to some other more lucrative rocation.

The professors are selected from the Indian Mredical Service with special reference to their aptitude to teach the different branches. The principal cliairs, medieine, surgery and obstetrics, are occupied by men who have had an extensive experience, while the primary branches, especially pathology and bacteriology, are usually taught by the younger members of the service. Native graduates hold subordinate positions in the teaching force as assistant professors, instructors, demonstrators, tutors, ete. 'The professors who belong to the civil branch of the Indian Medical Service receive a salary according to their military rank and in addition they receive some remuneration from the college for their services so that, for instance, a lientenant colonel who has been in the service for 20 years may have an anmual income of $\$ 4,800$. In the event of his death, his widow receives a pension of $\$ 750$ a year and each of his children $\$ 150$ a year, the sons until they reach the age of 21 years and the daughters until they become married. The pensions are provided by a fund to which each officer contributes. When an officer gets married he pays into this fund 2,000 rupees $(\$ 640)$, and 1,000 rupees $(\$ 320)$ after the birth of every child. At the end of 25 years, on retiring, he receives a pen- 


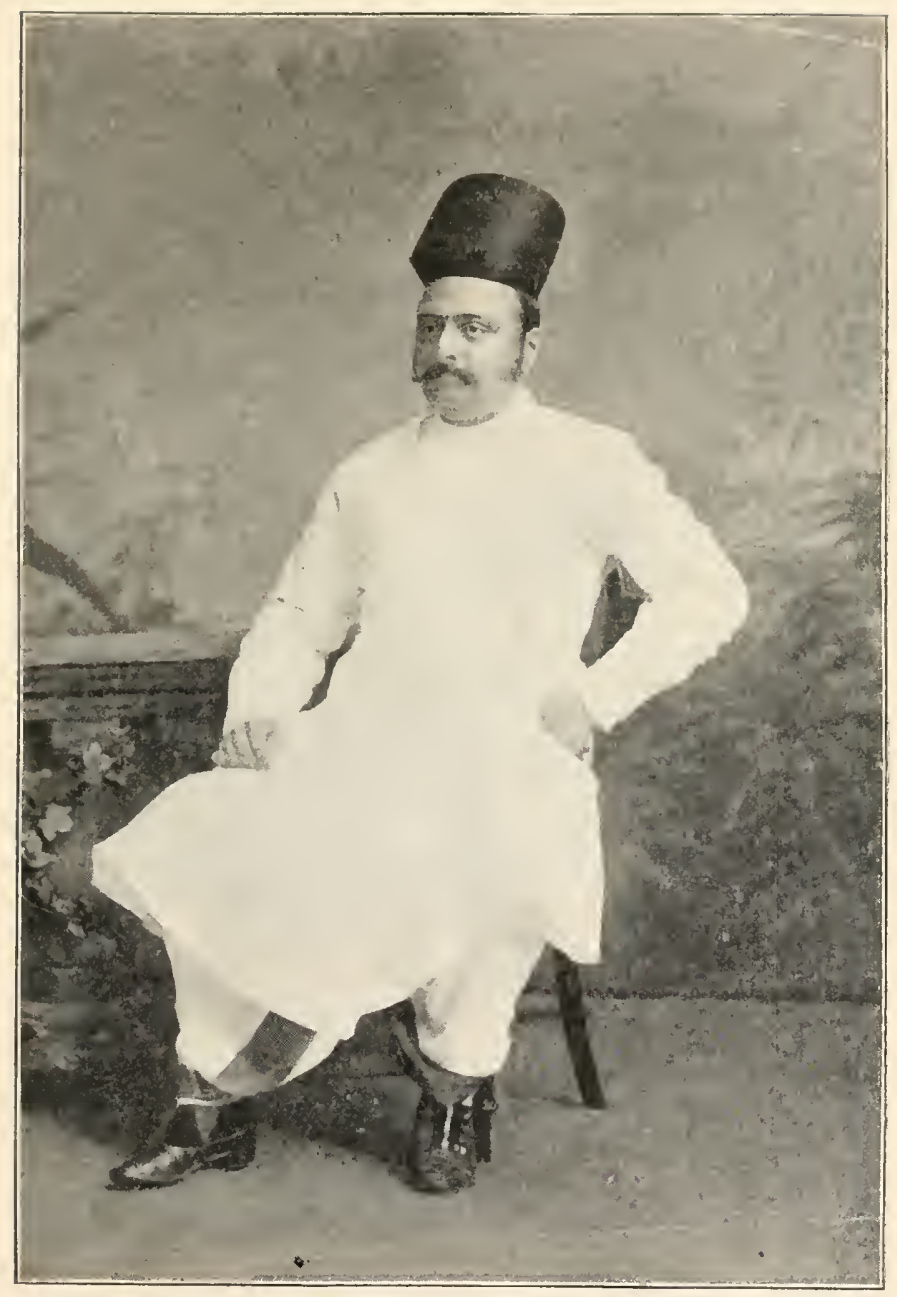

Fig. 45.-A Parsee. 

sion of $\$ 2, \pi 00$ a year. The teaching duties of these men are so exacting that they are given but a slight chance to increase their income by private practice, which is. lowerer, permitted.

The original Grant Medical College, so called in honor of one of the former governors of Bombay, is a substantial, venerable, two-story stone building. With the increasing remand for space, additional buildings have been crevetel. The anatomy building (Fig. 49). now nearing empletion, is a two-story, massive stone

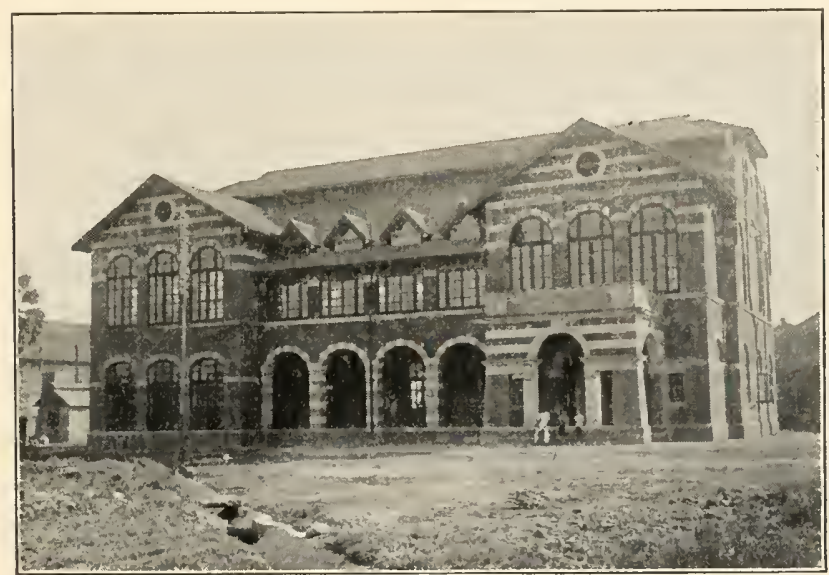

Fig. 4!.-Anatomy Building. Grant Medical college.

building, with marble floors; the upper story is the dissecting room, which is flooded with light from all directions. It is unquestionably the finest dissecting room in the world. Connected with it is a small separate building, corered with wire screen for the purpose of excluding rultures and erows, in which the bodies are prepared and the bones of the dissected subjects are cleaned and mounted.

The chemical and pathologie laboratories are inadequate for the present requirements and it is hoped that separate huildings will soon be erected for each of these very important primary branches. With an ever in- 
creasing attendance, the lecture rooms will also soon become too small. The curriculum of study for the M.B. and B.S. degrees extends orer fire years and includes the following studies:

First Year.-Biology, botany, chemistry, practical chemistry, materia medica, practical pharmacy.

Second Year.-Anatomy, botany, chemistry, practical chemistry, materia medica, practical pharmacy, physiology.

Third Year.-Physiology, histology and practical physiology, anatomy.

Fourth Year.-Medicine, surgery, pathology, hygiene, diseases of women and children, demonstrations in pathology, clinical practice in medical, surgical and obstetric wards. Attendance at male and female outpatient rooms. Attendance at pathologic room.

Fifth Year.-Surgery, medicine, diseases of women and children, operative surgery, clinical practice in medical, surgical, obstetric and surgical wards, attendance at pathologic room.

$\Delta$ glance at the curriculum shows what attention is paid to the primary branches, especially chemistry, anatomy and botany, the last of these entirely ignored in most of our medical colleges and the first and second only too often treated in a stepmotherly way. The students are not pestered with unnecessarily frequent examinations, as only two examinations a year are held, at the end of each semiannual term.

The military pupils, of whom there are now $\$ 6$ in attendance and who finish their studies in four years, have a somewhat different curriculum of study to follow. It is as follows:

First Year.-Anatomy, descriptive and surgical, dissections, anatomy and physiology, materia medica, chemistry and practical chemistry, compounding dispensary.

Second Year.-Anatomy, descriptive and surgical, 
dissections, anatomy and physiology, materia merlica, chemistry and practical chemistry, compounding dispensary.

Third Year.-Medicine and clinical medicine, sulgery and clinical surgery, diseases of women and children, hygiene, pathology, hospital practice and out-door dispensaries, postmortem examinations.

Fourth Year.-Medicine and clinical medicine, sulgery, clinical and operative surgery, diseases of women and children, practical toxicology, clinical, medical, surgical, obstetrical, and ophthalmic wards.

Fourth year students and third year military pupils attend in rotation at the male out-patient rooms as arranged by their teachers. Female pupils attend at the female out-patient rooms. Four and five didactic lectures, from 10 to 3 or 4 p. m., are delivered daily except Saturday, on which day only two lectures are given, during the forenoon. The clinics in the Jamsetjee Jeejeebhoy Hospital begin at 7 or $7: 30$ a. m. and are held daily. This is the hospital in which the clinical teaching in medicine and surgery is done exclusively. The present teaching staff consists of eleven professors, one demonstrator and eleven tutors. Lieut.Col. H. P. Dimmock, I.M.S., is principal of the school and professor of obstetrics, gynecology and diseases of children, and Lieut.-Col. Quicke, I.MI.S., is professor of surgery, operative surgery and surgical anatomy.

The final examination in this college appears to be quite a severe one, as every ycar only about 45 per cent. of the candidates for graduation are recommended to the Bombay University, with which the college is affiliated, for the degree. Those who fail may come up again for examination at the close of the next or of any other subsequent term.

The military pupils are prepared for the assistant surgeon branch of the Indian Subordinate Medical Department. They must be of European or Eurasian parentage, not less than 16 and not more than 18 years 
of age. They must pass a satisfactory physical examination and are examined in the following subjects: English, handwriting, dictation, composition, explanation of idioms and grammar questions. History and geography-The outlines of English and Indian history, and the elements of physical and general geography. Mathematics-Arithmetic: The four simple rules, vnlgar and decimal fractions, reduction, practice, proportion, simple interest, extraction of square root. Algebra: The four simple rules, proportions, simple equations; Euclid, first book. Vernacular-Hindustani, colloquial.

They are educated at government expense. Pupils who obtain less than 33 per cent. of marks in each subject of their final examination will be liable to remoral from the college. Such pupils, however, will be allowed to remain for a further period (to be fixed by the principal in each case) in the college to continue their studies at their own expense. Military assistant surgeon graduates from this department of the college are employed in hospitals of British troops and in military and civil appointments; those in ciril emplorment being arailable for military duty in time of war or other urgent necessity. This branch of the military medical service is entitled to the following pay:

1. Senior assistant surgeon, with honorary rank of captain. 400 rupees (\$128).

2. Senior assistant surgeon. With honorary rank of lientenant, 300 rupees $(\$ 96)$.

3. Asistant surceon, first class, 200 rupees $(\$ 6 t)$.

4. Assistant surgeon, second class, 150 rupees $(\$+8)$.

5. Assistant surgeon, third elass, 110 rupees $(\$ 35.20)$.

6. Assistant surgeon, fourth class, 85 rupees $(\$ 2 . .20)$

In addition to this pay they receive allowances when on special duty, and traveling expenses, and pensions on retiring from the service. Retirement is compulsory at the age of 55 rears. 
PATHOLOGIC MUSEUM.

The pathologic museum of Grant Medical College contains a very large amount of material illustrative of tropical diseases. It is the result of accumulation of specimens for 60 years and should contain more than it does, but the opposition to postmortem examinations is so violent and persistent that permission is only seldom obtained. No Parsee corpse has ever been tonched by a pathologist except under medico-legal pressure. Not many years ago a postmortem was made on a Mohammedan and when the fact became known it gave rise to a riot in the hospital grounds, which it was found difficult to suppress. Since that time the Mohammedans employ a salaried guard, who watches the approach of grim death in the hospital. and, if the patient is a Mohammedan, he sees to it that the corpse escapes the postmortem knife. The Hindus furnish the material for the museum almost exclusirely.

This unreasonable objection to postmortem examinations by a large proportion of the population of Bombay has seriously interfered in collecting a larger material. A catalogue of specimens in the Pathologic Мruseum was prepared by Capt. G. F. Gordon, I.MI.S., in 1903 , and was published by the government in the form of a well bound and well printed book of $24 \%$ pages. I will quote here a description of only a few of the most interesting specimens:

Pneumonic Plague.-The lung is solid throughout, greatly enlarged, and the visceral pleura covered with slate-colored blotches, which are subserous hemorrhages. This specimen was from a patient aged 26 , who was ill abont three days. One section of the lung was filled with light colored masses, which were surrounded by areas of acute congestion. The lower were more markedly affected by consolidation than the upper lobe. There were several hemorrhages in the cellular tissue of the posterior mediastinum, and the other viscera were acutely congested. 
Syphititic Fibrosis of the Lung.-A portion of the left lower lobe, showing broad bands of fibrous tissue running through it, the largest proceeding from the base of the lung in an upward direction. The section shows very little lung parenchyma, and that in a most condensed state. Numerous openings of vessels and dilated bronchi are seen, closely agglomerated from the shrinking process which has gone on. The affected portion of the lung seems to be shut off from the more healthy part by a broad band of fibrous tissue. The specimen was taken from a man whose leg was amputated for chronic ulceration; a Hindu aged 40 years. There were a few caseous nodules in the right ling; the capsules of the liver and spleen are greatly thickened, especially of the latter. There was a gumma in the spleen; both testieles had undergone fibroid degeneration with thickening of the tunica vaginalis. There was a left hydrocele.

Aneurism of the Heart.-At the upper posterior part of the left ventricle, immediately to the right of the mitral valve, is a pouched condition of the septum measuring fully $1 \frac{1}{4}$ inches across at its mouth and an inch deep at the deepest part. The pouch is lined with thick, opaque endocardium. The right group of chordæ tendinex is thickened. There is thickening and contraction of the mitral orifice. In the right ventricle is a patch of opaque endocardium at a point covering the ponch in the septum. The patient was a male Mohammedan, aged 60 ; ill for weeks. The aorta was atheromatous, a breaking down gumma was found in the liver, the capsule of which was extensively scarred. The right kidney was atrophied and contained sandlike calculi; left kidney hypertrophied; fibroid left testicle; ulceration of large intestine. It is suggested that it is a case of syphilitic myocarditis, with resulting fibroid degeneration causing weakening of the septum. Malarial IIepatitis.-Section of a highly pigmented liver, which is hard and has a mottled appearance on 
the surface. 'The surface of the section is granular. such livers are, as a rule, slightly enlarged, uniformly tender, associated with slight jaundice, sone evidence of bronchitis at the base of the right lung. and therefore they are often diffienlt to distinguish from cases of hepatic abscess.

IIepatic Absces. - This shows the upper surface of the liver, where an abseess had burst through the rliaphragm. There were three large abscesses in the right

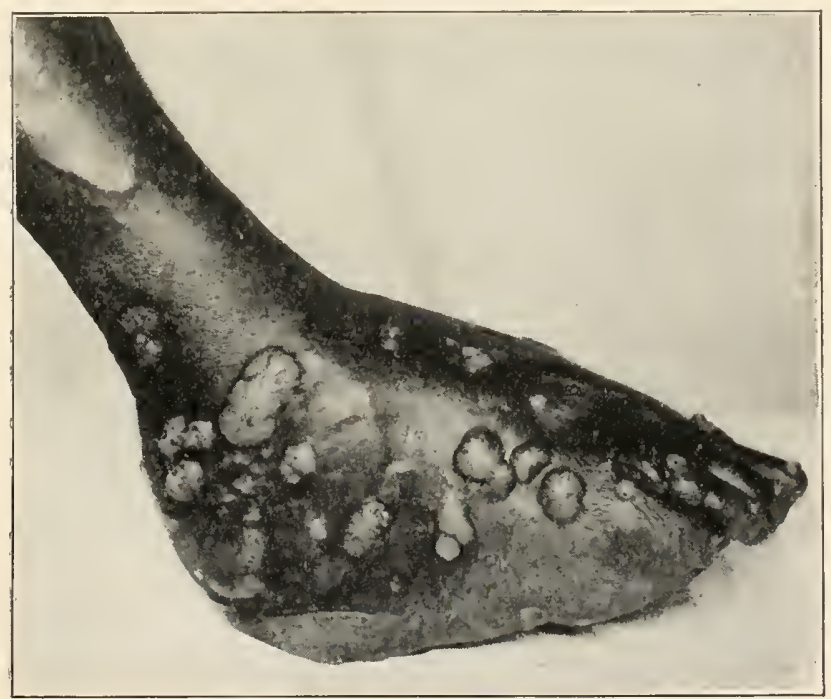

Fig. 50.--Madura foot. Amputation by Professor Quicke.

lobe. One had intricate connection with the diaphragm, which formed the upper wall of the abscess cavity. In this were two minute perforations, which communicate through the thickened pleura, with a pneumonic patch in the base of the right lung. The patient was a Mussulman, aged 2S. The illness commenced with an attack of dysentery, three months prior to admission. No signs of dysenteric ulcerations were found in the bowel at the posmortem examination.

Enormous Calculus of the Bladder.-This stone (uric 
acid and urates) is probably one of the largest stones ever removed from the human bladder. About half of the stone is shown in the central compartment and the fragments are grouped around it. The operation in this case was performed in $18 \% 6$ or $18 \% \%$ by the late Apothecary White at Tando Alyhar Dispensary, near Hyderabad, in Sinde. The patient was a man 25 years old and had suffered from symptoms of stone since childhood. An attempt was made to extract it by the lateral operation, but this being unsuccessful, the suprapub c operation was performed. Even now it was found impossible to extract the stone. By means of some improvised instrument (a craniotomy forceps), the stone was broken in pieces and removed. The patient lived for about twelve hours after the operation. The weight of the stone was 30 ounces and 95 grains.

Ainhum of the Small Toe.-This curions condition generally commences on the inner and plantar surface of the little toe. It begins as a narrow groove on the skin, which slowly deepens. The groove involves the whole circumference of the digit, the distal portion of which swells up as if it had been constricted by a ligature. The digital portion finally becomes a round, dangling mass and aiter some years drops off. The fourth toe is next affected, and so on.

Mycetoma or Madura Foot. - The shape of the foot is characteristic (Fig. 50). The disease is absolutely localized to the foot, the circumerence of the leg ahove the ankle not being increased. The skin of the foot is corered with pellets, some of which have been cut across to show the rellow fat y material of which they are composed. A window has been cut on one side of the foot. A capsule of thick, dense, fibrous tissne enrelopes the foot and this hardened tissue is honeveombed with small cavities, which lodge the yellow bodies in the interior of the bone, which has fallen away from the tissues and which ean be seen riddled with large communicating cavities. The specimen was ohtainer by 
amputation and presented to the musemm by the operat tor. Professor Quicke (Fig. 50).

Anesthetic Leprosy. - I dissection of a leprous font made by the late Dr. Van Dyke ('arter. The nerres are considerably thickened, espeeially on the plantar surface. The great toe has been lost, and all the digit: except the midlle one, are partially absorbed.

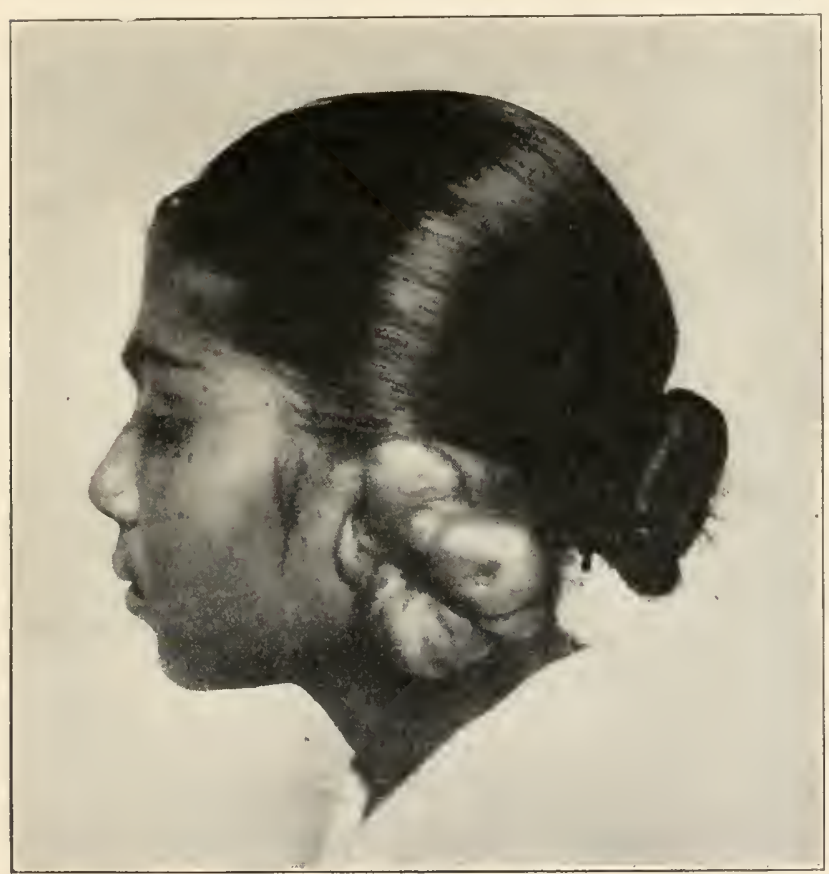

Fig. 51.- Fetoid of punctured lobe of ear. Excision. with wort cosmetie results, by l'lofessor Quicke.

Guinea Wrom.-This is a long, thin worm from 1? to 40 inches long. 'The female only is known as a parasite in the hmman body. It wanders into the loose subcutaneons tissues of the leg. serotum and sometimes the upper limb, and there generally forms an absecs or it may form a vesicle from which the extremity projeets, when it an be gratually removed by slow trac- 
tion extending orer some days, the protruded porion being wound round a stick.

Jamsetjee Jeejeebhoy Hospital.-The Jamsetjee Jeejeebhoy is one of the oldest and best known of the many Bombay hospitals. It bears the name of the Parsee who built it at his expense and presented it to the govermment in 1845, the same year that Grant Medical College opened its doors to medical students. Mr. Jamsetjee Jeejeebhoy was a poor man, but made a fortune by buving and selling bottles nearly a century ago, hence the hospital is still well known under the name of "Bottle IIospital." Mr. Jamsetjee Jeejeebhoy was linighted by Queen Tictoria in recognition of his many deeds of charity, and a full sized statue of stone in a half reclining position in the main entrance hall of the hospital docs honor to the memory of its founder. The hospital is for the exclusive use of the native sick poor and is maintained entirely at government expense. The hospital is an immense one-story stone building, with accommodations for 360 patients. It is an oldfashioned structure, which lacks many of the important features of a modern hospital, and it is about time that it should give way to a new building better adapted for present requirements.

Three new two-story stone pavilions were opened in 189\%, the Sir Dinshaw Petit IIospital for diseases of women and children, the Bai Mothabai Maternity and the Ophthalmic Hospital, each with a capacity for about forty patients. These new buildings are modern in their construction. are well furnished and have excellent little operating jooms. The nursing is also better than in the old hospital. About 800 women are delivered annually in the Maternity Hospital, and two students attend each case; this gires them an excellent opportmity to becone conversant with practical obstetrics. The most careful aseptic precautions are employed and sepsis in in-pationts is almost unknown. The delivery room has all the anstere appearances and sim- 


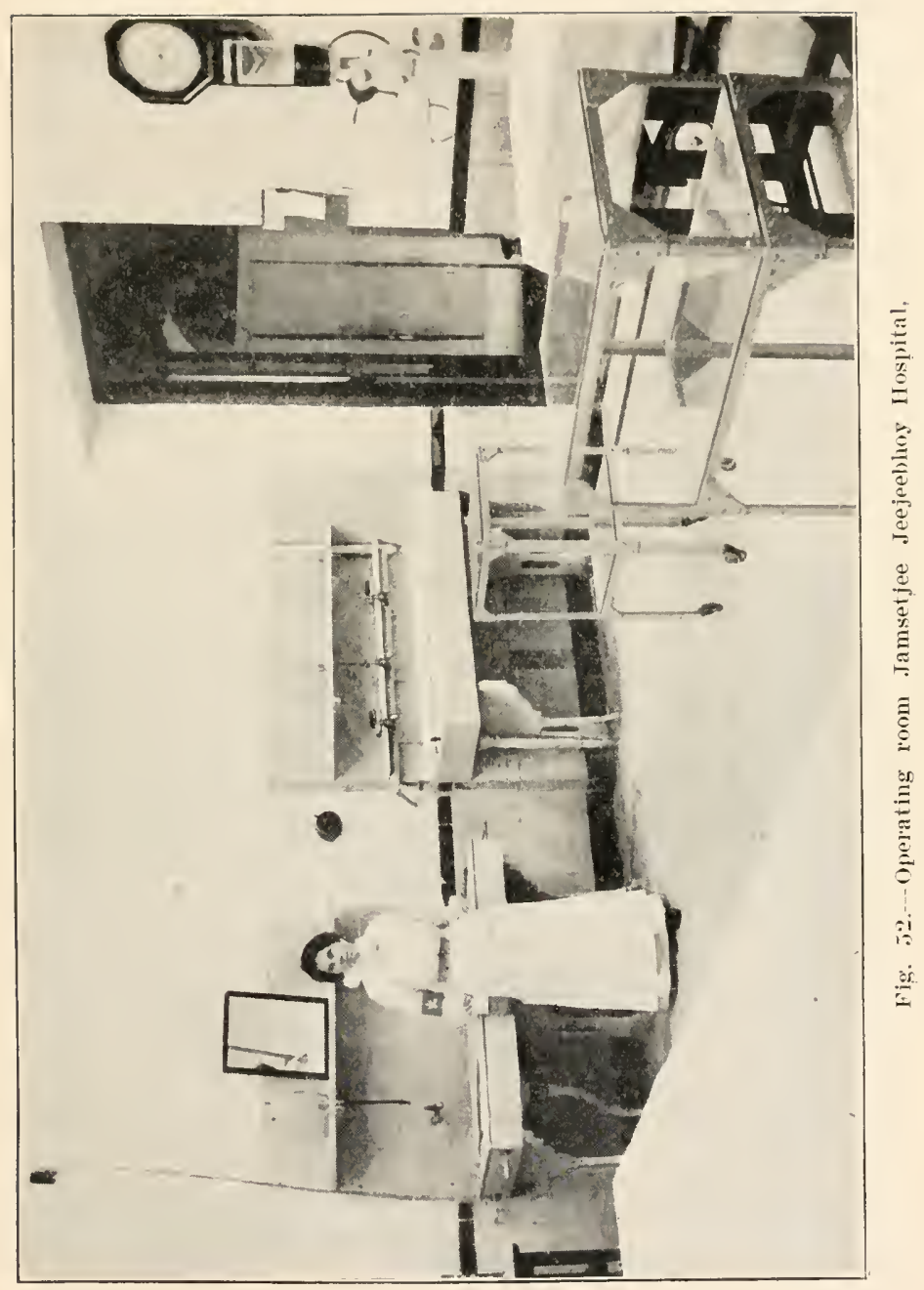



plicity of an operating room. Two women were in labor when I visited this department of the hospital.

Professor Dinmock showed me a number of interesting cases on which he had recently performed major grnecologic operations. In the old building a small warl has been converted into an operating room supplier with the most primitive outfit for ascpsis. (See Fig. jo.) What this hospital is sadly in need of is a new and separate operating theater and a more complete set of surgical instruments. It is a great injustice to the surgical staff to be obliged to perform 5,000 operations anmully under such trying circumstances. All hospital surgeons in India confess that it is extremely difficult to prepare a native for operation. A patient recently admitted to the surgical wards of Professor Quicke for the purpose of undergoing an operation for the radical cure of an inguinal hernia, brought with him the following sources of infection: Scabies, ringworm, diffuse furunculosis and pyorrhea alveolaris.

The mursing of this institution leaves much to be desired. The trained female nurses are inadequate in number, and it is only recently steps have been taken to organize a training school. Most of the nursing is done under their supervision by male and female ward attendants. The house staff, consisting of three medical officers of the Indian Subordinate Medical Department, is made up of a house surgeon and two assistant house surgeons. The house surgeon has charge of the property, his work being largely that of an execntive officer, but, in the absence of the regular attending stafi. he attends to the emergency cases, medical and surgical. The first assistant surgeon has charge of the drug room and dispensary, and the second assistant attends to the admission of patients and makes the preliminary examinations. The fourth and fifth year students do much of the dressing. under the supervision of the house surgeon and attending staff, and they assist at operations. The bedside clinies are an important 
feature of the clinical teaching in this, as well as in all other medical colleges in India. The attending staff of this hospital consists exclusively of the clinical teachers of Grant Medical College.

\section{PREVALENT DISEASES.}

Tropical abscesses are rery common in Bombay. They affect most frequently the thighs and gluteal regions. They do not give rise to serious constitutional symptoms and the local symptoms are likewise mild. Speedy healing after incision and drainage may confidently be expected. Tetanus is most frequently met with during the two hottest months of the rear, April and May. The serum treatment has not had an extensive trial, and the mortality is large, more than 50 per cent. In one case an intra-cerebral injection of the antitetanic sernm was made. The patient died. On postmorten the serum was found at the site of injection, no absorption having taken place. In the treatment of tetanus, hydrate of chloral and potassic bromid in very large doses are relied on. Hydrophobia is quite prevalent in India. Bombay sent last year 65 cases of suspected dog bite to the Pasteur Institute at Simla. Elephantiasis of the scrotum is much more common among the Parsees than among the Hindus. Patients thus affected now seek surgical relief before the weight of the swelling becomes a source of great inconrenience, as the former objections to the operation have been orercome by the better operative results. Many cases of hydrocele in young men develop during the hottest months of the year. About from fifty to sixty patients with stone in the bladder apply for relief every year.

Hernia in women is very rarely met with in India, and the surgeons believe that this is due to their spare bodies and the vigorous exereise incident to the hard work the common women are required to undergo. Sereral cases of Madura foot and ainhum find their way into the hospital every year. Actinomycosis and blas- 
tomycosis are not lnown here. In the coolies gonorrhea pursues a very mild course. No local treatment is used. Under internal use of an alkaline mixture, the disease subsides in the course of ten days.

\section{HOMELESS LEPER ASYIUM, MATUNGA, BOMBAT.}

One of the most creditable and beneficial of the hundreds of charity institutions of Bombay is the Homeless Leper Asylum in the suburb Matunga. It is the largest leper asylum in India, and at present it is the home of 3\%0 lepers. The inmates are well cared for, and instead of living the lives of outcasts in misery, beggary and much suffering, are well housed, kindly treated, and their discomforts and pains alleviated to a remarkable degree. Segregation has never been carried into effect, and there are now about 150 vagrant lepers roaming the streets of Bombay. Mr. H. A. Acworth, I.C.S., C.I.E., municipal commissioner for the city of Bombay from 1890 to 1895 , is the founder of this model institution, as it was through his influence that the necessary funds were obtained. Rich merchants and native princes responded to his appeal and made liberal contributions. The many tile-roofed, onestory brick pavilions are situated in grounds embracing 111/2 acres of fertile land, advantageously located, enclosed and unenclosed; municipal and leased from the government at a nominal rent. On the morning of Nov. \%, 1890, about fifty vagrant lepers were collected by the health department and the police at various centers and, after medical examination, were sent to the asylum under police escort and, after thorough cleansing and change of clothes, were entered as the first installment of patients of the leper home. The poor lepers have since learned from experience and observation the full extent of the benign and humane. intentions of the asylum and now enter it voluntarily in increasing numbers, happy in the thought that by doing so their short lives will be made more endurable 
by the care and kind treatment which awaits them there. The grounds are beautifully laid out and ornamented with trees and flowers. The garden of roses is one of the finest in Bombay. In the grounds there is a school for children, a Roman Catholic Church, a Hindu temple and Mohammedan mosque. All the Hindus that die in the asylum are cremated by the inmates, according to the Hindu custom. After appropriate ceremony, in a place set apart at the extrene east corner of the grounds, the rites incidental to "cremation are performed by the patients themselves, and one khandi (28 maunds) of firewood is allowed for each corpse, at a cost of $81 / 2$ rupees (\$2.72). A bier and pall are provided for the Mohammedans and the corpses are removed to the cemetery at Marine Lines by bearers, who are sent from the city and are paid at the rate of about 7 rupees (\$2.24) per corpse, to defray the charges of conveyance and all incidental expenses. A Mohammedan priest, who has been the subject of the anesthetic form of leprosy for 11 years and an inmate of the asylum for 5 years, attends to the spiritual needs of those inmates of the asylum who are of the same religious belief and receires a small salary for his services. A Roman Catholic priest from Bombay visits the asylum regularly every week. The Roman Catholic dead are remored from the asylum for burial at the expense of their fund, all arrangements being made for the purpose by the Rev. Father Peters, S.J. The Protestants have a pauper funeral at the expense of the asylum funds. The Protestant missionaries do not seem to be aware of the existence of the Homeless Leper Asylum or its contingent of protestant inmates. One of the most interesting features of the asylum is the small sewage farm connected with it, and which is fertilized with sterilized sewage. The sterilization is effected by collecting all the sewage and passing it through a series of open tanks. This method of sterilization and utilization of sewage has been. found 
cntirely satisfactory and has been a source of no inconsiderable income to the asylum. 'The report of the asylum shows about the following proportion of the various religions beliefs of the inmates:

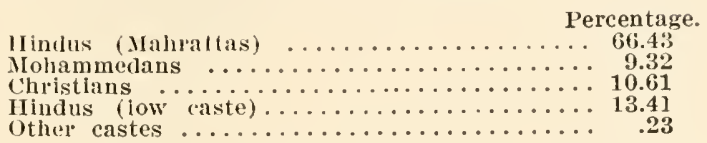

There are about twice as many men as women, and the children constitute about 2.51 per cent. of all the inmates. One of the touching instances among the many I saw in visiting this great institution was a group of children, numbering about 15 , who had just left the schoolroom and had congregated near the gate of entrance to the grounds to bid the visitors good-bye. They ranged in their ages from 6 to 12 years and were all lepers.

The anesthetic and tubercular forms of the disease are about equally represented, and the mixed form affects about 12.63 per cent. of all cases. The dispensary is well supplied with medicines, the hospital is scrupulously clean and supplied with comfortable cots. A physician visits the asylum erery day, and his assistant resides in the institution, always ready to render necessary medical and surgical aid.

THE PLAGUE RESEARCH LABORATORT OF THE GOVERNMENT OF INDIA, PAREL, BOMBAY.

This institution owes its origin to Mr. W. M. Haffkine, C.I.E., a Russian scientist, who has rendered India such signal service sinee 1893, first by his prophylaetic treatment of cholera by serum inoenlations and later by his discovery of a serum against the plagne. I was very anxious to meet Mr. Haffkine, but unfortunately he was absent on a visit to Europe, but I met in his place Lieut. Col. W. B. Bannerman, M.D., B.S.C., I.M.S., who temporarily filled his place as director-inchief of the laboratory and who holds the permanent 
position as superintendent. The former residence of the governor of Bombay, at Parel, a beautiful suburb, has been converted into a laboratory and the former ballroom is now the place where the anti-plague serum is brewed, and halls and bedrooms where fashion reigned are now occupied by dozens of cages containing animals for experimental use.

According to a paper presented by Lieut. Col. Bannerman to the Royal Society of Edinburgh in 1902, the serum treatment, in the prevention of the bubonic plague, derised by Haftkine, is reliable and specific in its results. The immunity thus obtained remains throughout an epidemic and has been known to last two years; its exact maximum limits. however, remain undetermined. The serum is prepared on a very large scale and is sent wherever needed free of expense through gorernment chamnels. Wide bottles with long, narrow necks. holding about a liter, are filled with bouillon and the culture medium is inoculated with the plague bacillns. A characteristic growth in the form of innumerable hanging stalactite-like threads forms. It the end of two months the culture is sterilized by boiling and is kept ready for use in another room. The culture and serum rooms contain hundreds of these bottles, protected against contamination by a cotton plug with ends burnt off. The prophylactic treatment consists in making a single hypodermatic injection of from 4 to 5 c.c. of the sterilized culture under strictest aseptic precautions. All subjects thus treated hare escaped the disease, even in badly infected districts. The experience with this serum has reached enormous dimensions and its absolute reliability can no longer be questioned. Accidents have happened, but they could always be traced not to the serum per se, but to its improper administration. Bannerman concludes his paper as follows: "The final conclusion, then, appears to be that in this discovery of Haffkine's we have within our reach a means of controlling an epidemic of plague and 
converting it into a manifestation of sporadic cases only, easily controlled and exciting little alarm."

Haflkine receives a salary of 2,000 rupees $(\$ 640)$ a month. an amount not any too large for the man through whose scientific researches two of the most dreadful epidemic diseases of India are on the way to extinction.

BOMEBY BUBONIC PLAGUE IIOSPITAL.

During my tour through the tropics I made frequent inquiries at the different ports for the purpose of finding an opportunity to see cases of bubonic plaguc. All the ports were free from this disease until I came to Bombay. For four years Bombay has been the center of an epidemic of this disease and in consequence a dreaded port for navigators and ship owners. The disease has passed its climax and is gradually being gotten under control. The plague hospital is located outsicte of the city limits and consists of a row of onestory brick buildings which serve as wards.

During the height of the epidemic as many as 30 patients a day were admitted from the city and nearby villages. The mortality has been very great. Many die from the general sepsis, others from pulmonary and other complications. After a period of incubation of from five to seven days, the disease is ushered in abruptly with very high temperatme and other symptoms indicative of a profound constitutional disturbance. The inguinal glands are most frequently involved. next the glands of the axillary spaces. The cervical glands are rery seldom affected. Enucleation of the suppurating glands has been tried, but was abandoned, as it was found that after such attempts to cut short the local infection, the general infection usually became aggravated.

The local treatment resorted to now consists in the use of poultices until fluctuation is distinct when the abscesses are incised and antiseptic ganze dressings 
take the place of the poultices. The general treatment is supporting and stimulating. Large abscesses frequently develop remotely from the infected glandular regions. At the time of my visit about 25 patients remained in all stages of the disease. Some of them were in the height of the primary fever, more of them were slowly recovering from extensive glandular abscesses in the inguinal regions. I saw only two patients in whom the axillary glands were also involved. In all the inguinal abscesses that had been incised the enlarged glands partially isolated from the surrounding tissues presented a grayish appearance with no indications of any attempt at repair.

Some of these survivors had been in the hospital for two or more months. One of the convalescents, who had recovered sufficient strength to walk about, had lost his speech, the result of cerebral complications which set in during the acute stage of the disease. All convalescents were emaciated to an extreme degree. Three heroic trained female nurses take care of the sick, aided by male and female helpers. One of these nurses has been on constant duty since the epidemic commenced, more than four years ago, and notwithstanding the arduous and trying duties that she has so faithfully performed her general health has not suffered; an interesting proof of woman's endurance under circumstances that would be a serere test on the strength of the strongest man.

A COBRA DEN.

My visit to the research laboratory was made late in the day. It was during the short twilight and in the absence of electric or gas lighting we had to find our way through the dark halls and rooms of the former palace of the governors of Bombay with the aid of the light of a lantern. Lieut.-Col. Bannerman led the way. We passed through halls and rooms on the first floor between rows of cages containing rabbits, guinea pigs, rats and mice, and the little creatures, scared by 
the appearance of the late visitors, were roused from their dormant condition and displayed an activity begotten by fear. We finally came to the door of a large room in which darkness was complete. The moment we entered a fearful hissing from every part of the room greeted us, mingled with short raps resembling the tapping sound made by striking a wire screen with a small hammer. I was in a cobra den, in the midst of 150 of these terrible reptiles, imprisoned in cages, it is true, but wide awake and roused to anger by our untimely intrusion. They were assisted in their hissing and striking against the wire screen which guarded the open end of their cages by 50 other snakes still more renomous, Russel's viper. (Daboia Russelli.) Through themeshes of the wire screen shot the red forked tongues of 200 of the most venomous reptiles known. Add to the hissing and striking noises the 200 forked reil tongues, 400 staring, deceptive and treacherous eyes, the snaky odor that pervaded the atmosphere of their dungeon and you will have a good idea of what is meant by a cobra den. The cobra (Naia tripudians) is about four feet in length, and when angered the flat hearl and neck expand into wing-like projections on each side, increasing their width to the size of the palm of the hand. 'The color is almost black, the tail tapering into a sharp point. The viper is of about the same size, but has cireular stripes. I know of no more ugly sight than a cobra in striking attitude. Every snake in the room was in a fighting mood, hissing and striliing the wire screen with a thud-like noise; at short intervals red forked tongues shot out through the meshes of the wire screen on all sides, and the situation was made more horrible by the revolting snake smell issuing from so many cages.

The snake, the most despised animal in ereation, is an object of fear and horror to all who are familiar with his damnable record in the Garden of Eden, and with the curses imposed on him by the Almighty. I 
did not know but some of these terrible beasts might be at liberty in that large imperfectly lighted room, and breathed easy again only after we had left the room and the door was shut and securely locked.

It was prearranged that $I$ should become more familiar with the dangerous part of the anatomy of cobra and riper. We ascended the broad staircase leading to the second floor and entered the office of the superintendent of the laboratory, Lieut-Col. Bannerman, who on this occasion extended so many courtesies to me. He sent for the "snakeman." and in a rery short time three coolies made their appearance with as many snakes in their cages, one cobra and two vipers. I was to witness the "milking" of their poison sacs. I begged to be informed beforehand how this was to be done in order that I night make my own plans of conduct for safety during the ordeal. The superintendent smiled and said: "You must see for yourself." The snakes were in an offensive attitude, as they had undergone this procedure repeatedly and had learned by experience to dread it. I could see no opening in the boxes through which the snakes could be made hors de combat.

The "snakeman" was a rery slender coolie, with very long, thin arms and legs. and fingers like the claws of a monkey. (Fig. 53.)

The cobra, with its raised, expanded head in striking position came first. The man held a smooth stick the size of an ordinary cane and about two feet in length in lis left hand. Suddenly, standing behind the box with the wire screen directed toward him, he threw open the opposite side with a lightning jerk and out shot the angry monster, and in undulating rapid movements adranced toward me. A quick retreat on my part behind the table increased the distance between us. Before the snake had advanced three feet the "snakeman" grasped the end of his tail with a lightning movement of the right hand. lifted it high in the air. and with the stick passed from tail to neck pre- 


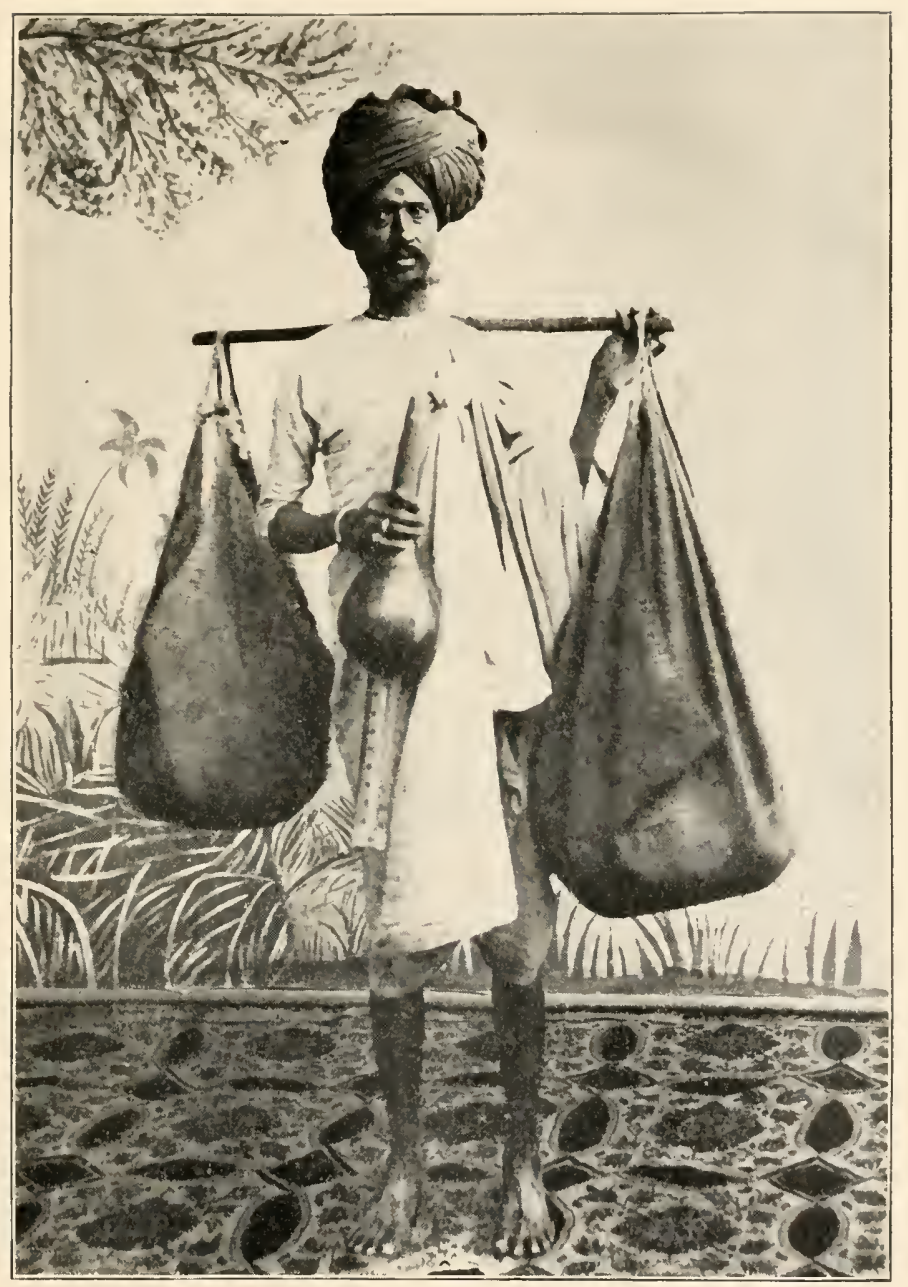

Fig. 53.-Hindu snake charmer. 

rented a recoil, lowered it to the floor. With the stick, the neck was pressed against the floor, the right hand, quickly substituted for the stick, grasped the neck firmly and with the left hand made traction on the tail, thus straightening ont the squirming body. A small goblet, covered drum-like witl American adhesive plaster with adhesive side direeted outward, was placel near enough for the snake to strike it. The fangs penetrated the plaster and by pressure against the poison sacs about half a dram of viscid opaque fluid eseaped into the sterilized goblet. The cobra was returned into the cage with the same expertness as characterized its liberation. The whole procedure did not occupy more than ten minutes. Snakes refuse all food during confinement, hence they are fed each time the poison is remored, which is done every 10 days. 'The long tip of a small funnel is inserted into the throat and about two ounces of a mixture of ego and milk is poured into the funnel, which enters the alimentary canal without meeting any obstruetion. 'The vipers were then handled in a similar manner, only that in their case the poison was received direct from the fangs into an open goblet by opening the mouth widely with a pair of forceps and steadying the fangs with a thread passed around them and on which traction was made by an assistant, who at the same time held the goblet. I conld see distinctly the drops of poison escape through the tiny opening at the very tip of the enormous fangs, which looked like fish hooks without a barb.

The poison is desiceated in the laboratory under aseptic precantions, and is later sent to another laboratory, where it is used in the preparation of Calmette's antivenen. There is no lack of an adequate supply of cobras and vipers for this laboratory as they are bought from the natives at from a few annas to one rupee each. 


\section{CALMETTE'S ANTITENENJ.}

Calmette of Lille is the discoverer of antivenene. Captain Lamb, I.M.S., ${ }^{1}$ who has made a very careful study of the therapeutic value of this agent in the treatment of bites of poisonons snakes has come to the conclusion that antivenene prepares from the renom of one genus of snake is curative only in the treatment of bites inflicted by that genus and no other, a position fully endorsed by Lieut.-Col. Bannerman. ${ }^{2}$ Convincing experimental research and a large clinical experience combine to prove that the antivenene prepared from the cobra renom is, if used in time, a specific for cohrd bites, but useless in the treatment of bites of the viper. Reasoning from this standpoint, it seems to me that in antivenene prepared from the renom of our rattlesnake ought to prove successful in the treatment of bites inflicted by this genus of snakes.

Only one accident has so far occurred in the Parel Laboratory. A coolie in handling a cobra strnck one of his thmulss against one of the fangs. Antivenene of doubtful age was used at once, but proved useless in warding off the immediate symptoms provoked by the poison. Great prostration set in, he became paralyzed in the lower limbs and unconscious. The threatening symptoms disappeared promptly and in three hours the patient was able to walk to his house. Gangrene of the end of the thuml, however. occurred. which proved the intensity of the local toxic action of the cobra renom.

Marseilles, France, Oct. 3, 1904.

1. Snake Venooms: Their Plysiological Action aud Antidote, Jumlinal Bombas Natural History Societs, ?. 220, vol. xir.

2 . The Use of Calmette's Antirenene in snakebites in ludiaa, Jomma liombay Natural Histdry society, vol. $x r$. 


\section{FOUR THOUSAND MILES THROUGH INDIA BY RAIL IN MIDSUMMER.}

When I decided to make a tour aromnt the world by way of Imlia. during mirlsummer, I knew beforehand that I would have no use in that part of the world for an orereoat or blankets. I was very well aware of the fact that that part of India which I expected to see har anl unenviable reputation as a summer resort. Information from different sources conccrning the climate of certain countries is about as reliable as hunting and hishing stories. In order to ascertain abont what I had to expect in the way of heat at that time of the year, I interviewed sea captains and people who had lived in India. 'The opinions expressed were so widely at variance that I remained in doubt concerning the real climatic conditions that I wonld have to encounter in that part of my itinerary around the world. A traveling companion from San Francisco to Auckland, a missionary, who had lived several years in the northern part of India, gave me the most discouraging account. He said that where he formerly resided the burning sun during summer heated the stones to such a degree that a simple tonch with the hand would result in a burn sufficient to blister the skin. An officer of the Indian Medical Service gave me the consoling information that when he was on duty at Calcutta he had to spend several hours each day in a cool bath during the summer months to counteract the intensity of the heat. Sea captains were only familiar with the climate on the coasts of India; they knew nothing about the summer climate of the great plains which I cxpected to cross. Their opinions on the coast climate were not unanimous. They could be formulated about as follows: Very hot, hot, quite hot, not so bad 
as has been represented. In riew of these testimonies, I approached the climate of India with a mixed feeling of hope and fear. After having crossed the equator twice on the way from San Francisco to Ceylon, I spent five days in the hot, humid climate of Ceylon, and for the first time fixed my eyes on "India's Coral Strand" early Tuesday morning, August 30. From subsequent experience, I would suggest the following change in the second line of the famous and well-known missionary hymn:

From Greenland's icy mountains From India's "burning" strand,

as this change would more forcibly indicate the difference in the climatic conditions of these two places which these lines are intended to convey. The first impression of India in landing at Tuticurin is very disappointing. Unlike the South Sea Islands and Ceylon. the coast is not fringed with palm trees; it is bare and barren. The country is level and vegetation very scanty. The part of India which I traversed, and the tour extended from Tuticurin to Bombay, via Madras, Calcutta, Benares, Allahabad, Agra, Delhi, Jaipur and Ahmedabad, is entirely devoid of interesting scenery. There are no forest-clad mountains, waterfalls, mountain lakes, babbling springs nor clear rivers. Most of the river beds are dry or are a succession of dirty pools, the farorite bathing and drinking places for man and beast.

The sacred Ganges at Benares is about the size of the Mississippi at St. Louis. It is the great sewer for millions of people; its dirty water is credited with great healing power by the superstitious population and is carried in earthern or brass vessels, or pigskins, great distances for drinking purposes, as it is supposed to possess virtues which will prevent and cure all lisinds of diseases. When we realize that the river is used as a receptacle for corpses, dead animals and everything that is filthy, it is difficult to comprehend how Mark Twain could come to the conclusion that its water is 
"the purest in the world and sing its praises. 'T'his great traveler has immortalized himself with the natives of India by lauding the purity of the Ganges water. He may be right from a bacteriologic standpoint, and his position would be upheld by the Chicago Department of Health, but would meet with violent opposition by the guardians of health of the city of St. Louis.

When I saw this sacred stream, its water was about the color of pea soup, and during a boat ride along its shores I saw a number of decomposed, bloated dead dogs floating on the surface of the sluggish stream, and at the place where the corpses of human beings are cremated, baskets of ashes were consigned to its sacred water. The soul of the Hindu finds no rest until at least a part of the incinerated remains is deposited in this river. From the ashes of the eremated bodies a few fragments of bones are taken, tied up in a cloth and sooner or later this ghastly bundle must be thrown into the Ganges, even if this part of the funeral rites require days and weeks and no inconsiderable expense incidental to the travel. It is fortunate that this river is inhabited by crocodiles, which can dispose, at least, of some of the bodies and carcasses which are thrown into it by the hundreds and thousands every day. In the inhabited parts of the country through which the Ganges passes, its shores are lined with washerwomen and washermen and human and animal bathers. 'The amount of human excreta which find their way into this stream is simply enormous, and other sourees of pollution are innumerable; henee, if nature's laboratory can cope successfully with so many sourees of contamination and render the water, if not clean, yet potable and bacteriologically pure, she has done what sanitarians so far have failed to accomplish.

I hare said that the part of India included in my tour lacks scenic beanty. It is monotonous. a great, level, limitless plain, covered by rich marshes on the west coast; deserts, pastures, grain and cornfields in 
the interior and along the Indian Ocean coast; rery little fruit culture anywhere. Between Madras and Calcutta, and in the ricinity of Jaipur, the monotony of the landscape is somewhat relieved by mountain ranges. which are, however, almost bare, dotted only here and there with chmps of shrubs and dwarfed, hardy, much-branched trees.

Water is India's greatest concern. On the amount of rainfall depends the success or failure of the crops.

All the results of agriculture are dependent not so much on reason and diligence, as on those most uncertain things, winds and weather."Cicero.

Deforestation has impoverished India, as it has the Holy Land, Greece, I'urkey, Spain, southern Austria, and parts of the United States. The building of reservoirs and dams to hold heaven's gift have succeeded only in part in preventing drouths when the rainfall is scanty. The government has at last recognized the true cause of the frequent drouths, and in 1880 passed laws prohibiting further forest destruction, and took active steps to restore what had been lost by the reckless, thoughtless, destructice work of man. The results of the efforts of reforestation are apparent in many parts of the country, and if this good work is carried on with the deserved energy, India will get its good share of rain in less than a hundred years; the farmer will reap, from year to year, the rewards of labor, famine will disappear and the general prosperity of the country will reach a degree nerer known before. Nature has made provision for reforestation of arid regions. In the desert of Sahara, along the banks of the Suez Canal, I noticed a shrub from 4 to 8 feet high, with a dark green foliage-the Tamarix tetragyna-in places where nothing else would grow. 'This shrub is pre-eminently fit for dry saline soil. The leaves are eaten by cattle. This shrub would flourish in the deserts of our western states.

At present the laboring classes spend much of their 
time and labor in holding and distributing the limited water supply. In some districts the government has established well-planned systems of irrigation, which have brought millions of aeres of arid land under suceessful cultivation. Beyond these areas, the farmer, during the dry season, spends most of his energies in supplying the arid soil with moisture by the most primi. tive methods. From pools, tanks and wells, water is drawn in pails, by hand, foot or bullock power, in the same way as was done a thousand years and more ago. I never saw a windmill in India. The water is poured into little gutters, which intersect the fields in different directions. Men, women and children are engaged in this kind of work. The women supply the household with water and, as the wells are frequently far apart, this task is often not an easy one. Hard as this work may be, it has its fascination for the women. They congregate at the well, chatter and laugh while the earthen or brass vessels are being filled, and, when perched on their well-balanced heads, return in files to their village, keeping up their lively eonversation until the one from the greatest distance finds herself alone. The erect, graceful stature of the laboring native women is largely due to this enforced useful gymnastie exercise.

A common way of dipping water from a tank or pool into an irrigating ditch is by means of a large waterproof basket made of palm leaves, to which is attached a piece of rope on opposite sides. Two persons swing this basket so regularly and skillfully that it catches the water on one side and discharges it on the other. To maintain the proper tempo of these swinging movements between the two persons so employed, a monotonous chant regulates the muscular movements. Pumps appear to be unknown. When bullocks take the place of man power, the water is drawn from the well in an immersed bueket, the traction rope running in the groove of a wheel about two feet in diameter. The bucket is swung in the desired direction by a man and emptied. 
The bullock's work is not so easy as it might seem. The run is a short one and the animal is not a very lithe one, and the constant turning movements must be much more fatiguing than the traction in a straight direction over such a short distance.

The elevation of water from a well by a beam, kept in motion by up-and-down movements by the to-and-fro walking on it of one or more boys, can not be regarded in the light of a childish play. The actors must be sure-footed in walking back and forth on the polished beam, and when the exercise is liept up for hours the muscles of the legs and back have certainly undergone a great strain, and when this work is done under the burning rays of the sun, it means a bodily exertion which would exhaust the strength of our best athletes in a surprisingly short time.

\section{ATTRACTIONS OF INDIA.}

I did not go to India with the expectation of seeing enchanting scenes, hence I was not disappointed at their absence. I had seen most of the finest scenery in the world, including Alaska, Yellowstone Park, Yosemite Talley, Switzerland, Norway, Tyrol, Siberia, West Indies, Central America, Tahiti, ete., and I came to India to see what is generally recognized as the most interesting country in the world. I came to India to see her people, temples, palaces, tombs, her works of ancient art, her trees, flowers and animals. Having seen as much as possible of these things during the short space of eighteen days, traveling at the same time more than 4,000 miles by rail and during the worst season of the year, I feel fully compensated for the risks incurred and the sufferings endured, and can only repeat what has so often been said, that the real traveler, not the sightseer, will find here more that will interest him than in any other country in the world.

Take away from the Holy Land sacred history an? its remaining landmarks, and it could furnish no such 
attractions as can India, the land of ancient history, civilization, art and seience. The tombs and pyramids of Egypt are modern when compared with the ancient temple ruins in India. The history of Rome is as of to-day when contrasted with the records of India, punetured indelibly in characters on palm leaves used as writing material for thousands of years, and carefully preserved in the temples, which are practically fireproof, and many of them never touched by the rude hand of war and plunder. 'The ancient history of Egypt must be studied, not in Egypt but in the British Museum. while to become familiar with the earliest history of India, it must be studied in India itself. India has landmarks in history that can not be transported like Cleopatra's needle, landmarks that would be ruined and made ralueless if they were taken from the places where they were built thousands of years ago. People from all parts of the world may be seen at a world's fair exhibition, but it is impossible to know them or to learn their habits and customs, their vices and virtues until they are seen at their houses, at their places of business, on their farms, at their public amusements, in their own environments. A native in a distant strange land on exhibition is no more of a native than is a lion in a cage to be compared with a lion in the deserts of Nubia.

And, after all

$$
\begin{aligned}
& \text { "The proper study of mankind is man."- } \\
& \text { Pope. }
\end{aligned}
$$

The average tourist wants to see beautiful scenery, to walk picture galleries, to attend operas and concerts. to get a glimpse of and, if it is at all possible, to come in touch with royalty or with persons of high position and social influence. The true traveler, on the other hand, spends much of lis time among the masses of the common people, the backbone of every nation. $\mathrm{He}$ is anxious to learn from his own observations what they do and how they live. He sees them work in the fields and 
he risits them in their huts. He visits the markets to learn what the country produces, and he aseertains the prices of foodstufis. He studies the habits and customs of the people, their elothing, their implements of agriculture and war and the tools of the artisans. He looks into the little shops and finds out what the people buy and sell. He makes a study of the trees, flowers and animals, domestic and wild. He frequents the botanic and zoologie gardens and museums. He takes special interest in the landmarks of history, aneient and nodern, and the educational advantages and religious beliefs of the natives of the country he visits. With such objects in view, there is no conntry in the world that offers a wider field and a richer material than India.

As I have indicated before, travel out of season in a tropic country offers advantages as well as disadvantages. Crowding on shipboard, in railway carriages and in hotels is aroided. There were only twenty first-class passenger's on the royage from Adelaide to Colombo, four from Colombo to Tuticurin and less than fifty from Bombay to Marseilles. At Madras, besides myself, there was only one guest in the Connemara Hotel; at Calcutta. in the Great Western Hotel, not more than ten; at Benares I had the Hotel de Paris to myself, so at Igra the Metropole, and at Delhi the Laurie Hotel, and at Jaipur, in the Rastum Family Hotel, besides mysel!, there was the Parsee woman doctor who will be referred to again further on. At Bombay, the magnificent hotel Taj Mahal, with 600 rooms, had less than sixty guests at the time of my visit. The Indian railways provide well for the first-class passengers. The first-class compartments have six sitting and four lying-down places, lavatory and a connecting small compartment for servants. Towels and bedding are carried by the passengers. During the six nights I spent on the train I shared such a convenient compartment only once with a fellow traveler, and during the day I was very seldom disturbed by additional passengers. I was never obliged 
to check my trunk, which was always brought into my compartment. All trains carry ice and soda; the former is sold at 4 centiv a pound and the latter at curent prices. 'The trains miake a stop of from 25 to 30 minutes at the eating stations at the usual meal hours observed in India.

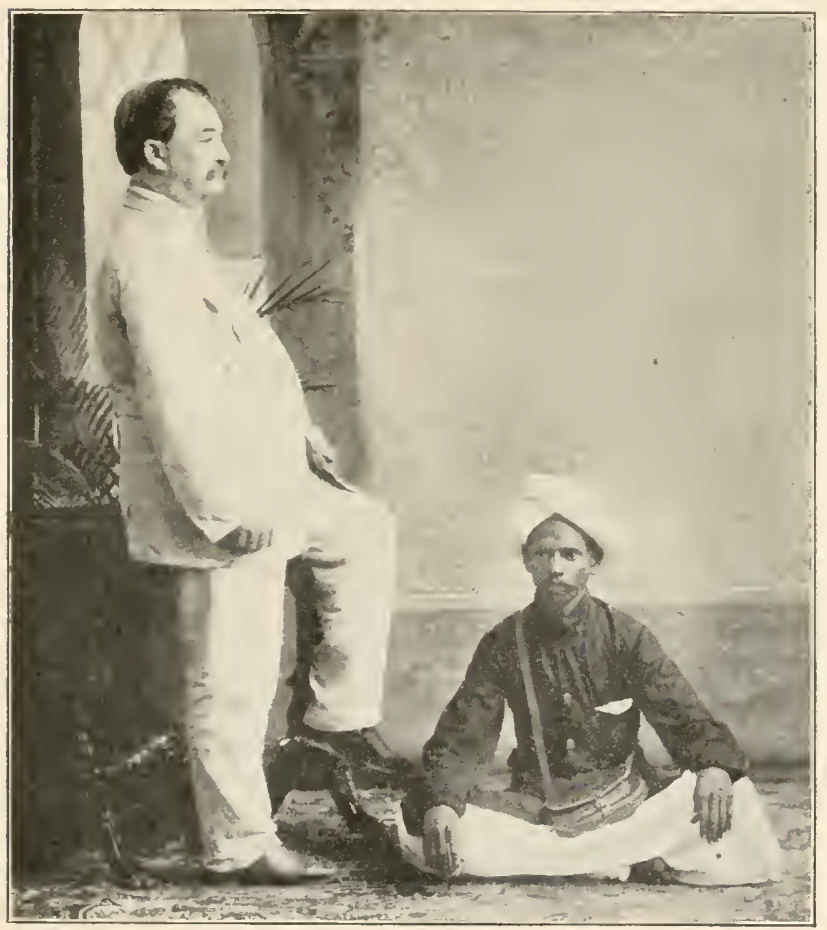

Fig. it. Master and servant.

M.ASTER AND SEIVINT.

In undertaking the trip through India at such an unseasonable time, I felt, for the first time in my life, the need of a personal attendant to relievo me of unnecessary care and physical exertion, and on its completion I had every reason to be satisfied with the step 
I had taken. To pack and to unpack, in a temperature ranging between 92 and $105 \mathrm{~F}$. every day or two and to take care of the baggage and bring it from station to hotel and from hotel to station in such an uncongenial climate, are tasks that should be avoided by the traveler and assigned to a coolie. At Colombo I engaged Lazarus, a Ceylonese Tamil, about 26 years of age, who was to accompany me as my servant from there to Bombay. The understanding was that I should pay his transportation both ways, third-class, and that he should receive a rupee and a half ( 48 cents) a day. The whole expense for the required time amounted to $\$ 35.66$. (Fig. 54.)

Lazarus was a typical Tamil, slender, lithe, coalblack, with sharp, rather intelligent eyes. He had a wife and two children and lived" near Colombo. He inherited the Roman Catholic faith and whenever we visited a Catholic chureh he sprinkled himself with holy water and made the sign of the cross. A closer acquaintance with him, however, threw some shadows on the religions life of this member of the Roman Catholic faith. His greatest failing was in money matters. Our accounts did not always agree, but, as the amount was usually small, his bills were generally passed and paid; howerer, as this was a daily affair, I am satisfied that some rupees, many annas and much copper found their way almost every day into a corner of his soiled handkerchief instead of loack into my pocket. I have learned by a somewhat expensire experience that a pigmented skin alohors truth and cherishes to represent things in the wrong light, and that whether yellow or black its owner. heathen or convert can seldom be depended on. I have learned to comprehend why the Devil, the father of lies. when pictured, is usually made to appear in black. Questionable as the little transactions of Lazarus may have been, his serrices proved invaluable and, in the end. I was the gainer so far as expense was encernerl. He was a rery good ser- 


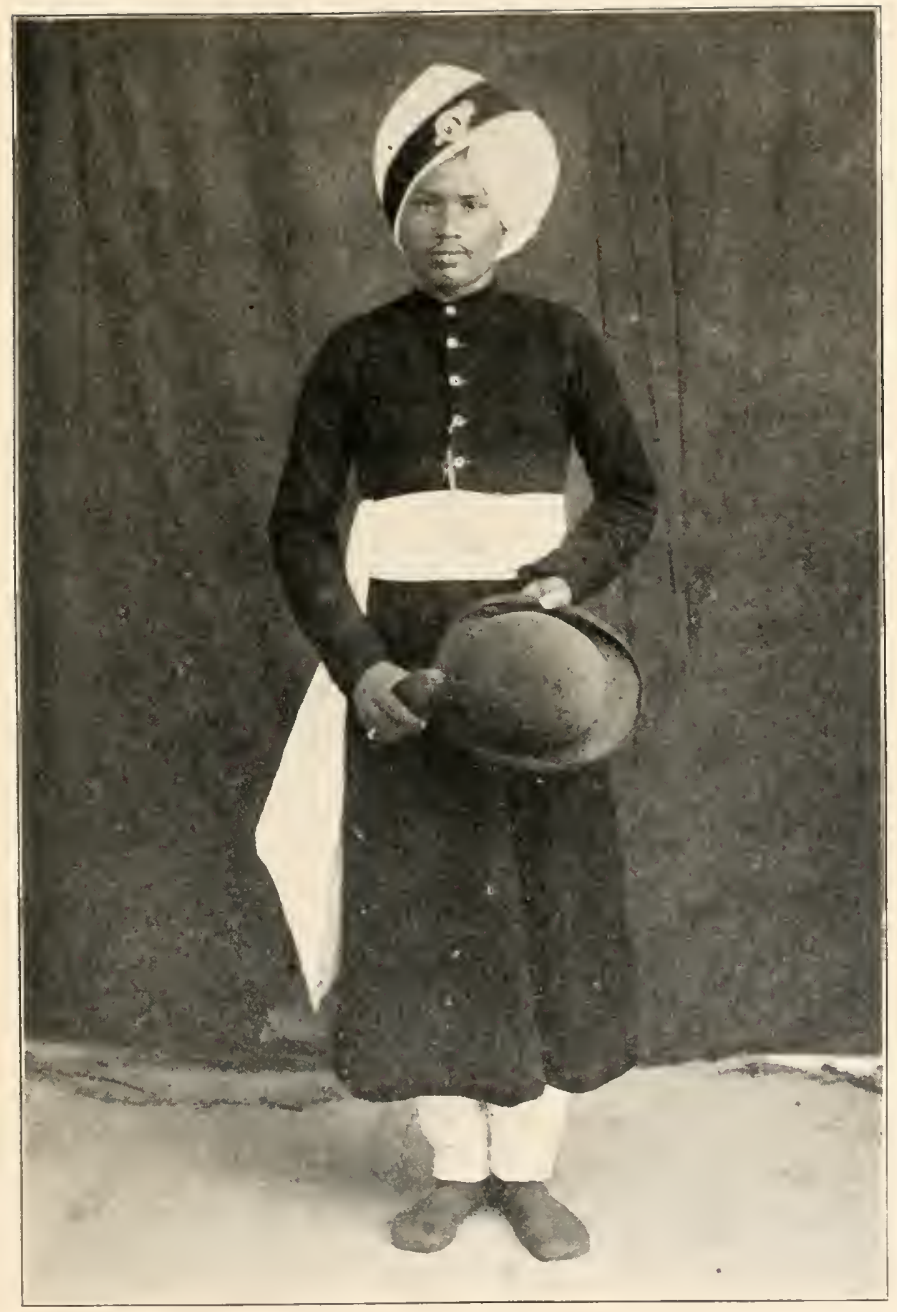

Fig. 55.-Hindu butler. 

vant. I could not lose anything if I tried. Things that I throw aside he would pick up and repack.

Iazarus had many unpleasant funetions to perform. 'T'ipping is the curse of the traveler. This nuisance has reached greater dimensions in India than in any other country. 'llipping in out-of-season travel grows as an nuavidable evil in proportion as the number of visitor's is diminished. In hotels and at railway stations the number of employees far exceeded the demand, anil as 1 was so often the only guest or first-class passenger, all eyes and hands centered on me. I made Lazarus my agent in the distribution of tips. It was be who converted large silver coins into smaller change, silver and copper. The coolies did not like to deal with me in such an indirect way, but the rule was an inflexible one and was adhered to from the beginning to the end of the trip. It was by this method of disposing of the tip muisance that both $I$ and Lazarus made money. The coolie, ignorant as he may be, has learned to distinguish between silver and copper and hates the sight of the latter. To pass through India with honor in the estimation of the coolie, it is necessary to carry a liberal supply of silver coins and to see to it that not too many get a hold of your baggage, as the carrying of an umbrella or cane scems to entitle the bearer to the same financial consideration as is tendered to the one who groans under the reight of the trunk. Lazarus was a source of the greatest comfort to me. $\mathrm{He}$ would inform me when to prepare for the next eating station and when the time came to change cars, or the approach of the station where I wished to interrupt the journey. He bronght me ice and soda whenever I was tortured by thirst, which was often the case. He was master of the Tamil, Singhalese and Hindustani languages, but his knowledge of English was very limited. This was perhaps on many occasions desirable, as he was rery loguacious, like all his countrymen. $\mathrm{He}$ would often discourse at length, but at the end I did 
not know in what language. Some of his pigeon English was amusing. In looking at some wild peacocks one day, he wanted to point out the bird with the brightest plnmage, and did so by calling him "man peacock." His pronunciation of any of the common Enslish words was so defective that they were absolutely unintelligibe. I had held out to him from the very beginning the inducement that if his services shonld prove satisfactory at the end of the trip he would receive, besides his daily wages, some gold, and in this I did not disappoint him when I bade him good bre at the Bombay dock. (Fig. 55.)

\section{INDIAN SUMMLER CLIMATE.}

The hot season in India begins with the month of April and is expected to end with the month of October. It is said that April and May are the hottest and that Norember, December and January are the coolest months of the year. On the way from Tuticurin to Madras the shade and night temperature rose to 98 $\mathrm{F}$. and the temperature in the sun to $119 \mathrm{~F}$. Soon after leaving Madras rain set in and continued without interruption until we reached Calcutta and during the first day I remained in that city. The atmosphere was saturated with humidity and added greatly to the discomforts and actual suffering from heat, although the temperature at night and in the shade did not exceed $98 \mathrm{~F}$. The air was not disturbed by the slightest breeze, it was motionless, paralyzed, stifling. Breathing required an effort and the sweat poured from the surface when at rest.

'. 'Heat, ma'am,' I said; 'it was so dreadful here that I found there was nothing left for it but to take off $\mathrm{my}$ flesh and sit in my bones." - - Sydney Smith.

How often did I enry those natives, with their lithe, slender, ratless borlies and their long arms and legs and flexible joints. In squatting, the easiest resting position for these natives, the legs fold on themselves like 
a jackknife. 'The arony I experienced from a combination of humidity, heat, and the lazy, sleeping air during the two nights and day I spent in Calcutta would be difficult, yes, impossible, to describe; bathed in sweat, panting for breath, with only partial relief from icc and soda and from vigorous pulling of the bedroom punkah throughout the night, by men employed for that purpose.

A word concerning the punkah puller. Two men or two women, or one man and one woman are hired for the night, and they receive 8 cents each for their easy work and loss of sleep. One night I had two men at the rope; about midnight the to-and-fro motions of the punkah became less and less and finally almost came to a standstill. I went to the door and found one of them sound asleep and the other barely awake. The slight jerks were directed by the spinal cord exclusively; the brain was sleeping. A few sharp words brought life to men and punkah.

I was made to comprehend by a trying experience the meaning of

"A dem'd, damp, moist, unpleasant body."Dickens.

I spent a whole forenoon in visiting the Calcutta Medical College and large government hospital connected with it, under the guidance of Major Drury, I.M.S., principal of the school. We inspected the laboratories, walked from ward to ward, climbed stairs innumerable and, although an attendant with an enormous fan accompanied us and gave us the full benefit of the useful article, I soon felt the sweat running in streams down my legs and into my shoes and, in spite of frequent wiping of face and neck, the collar soon wilted into a shapeless rag. It was then it occurred to me :

"Ay, now am I in Arden; the more fool I. When I was at home I was in a good place, but travelers must be content."--Shakespeare. 
For once I was glad when the risit was at an end and the courteons major took me to his private apartments, where a most luxurious breakfast was served and where my torturing thirst was quenched with ice and claret. As soon as we arrived in the room, the major suggested that I should make myself more comfortable by removing the eoat. I did so most willingly and then discovered to what extent the clothing had become saturated by the profuse sweating. Judged by the clothing, and found near the Ganges, the suspicion would have been well founded that I had been rescued a few moments ago from drowning in the sacred river. Without rain and sweating the clothing would become moist from the excessive humidity of the atmosphere. What discomfort and annoyance this creates. Try under such cireumstances to feteh in a hurry from the wet trousers pocket with a sweating hand a coin for a tip and you will find that the pocket becomes a veritable trap for the hand, which is with difficulty extricated without everting the pocket and scattering the coins.

It seemed to me strange that the temperature increased as I traveled north, but in leaving the coast the humidity gradually diminished, and in the interior the air was comparatively dry. The thermometer I carried with me registered $132 \mathrm{~F}$; on several occasions the mereury reached the maximum limit of the instrument in the sum and would undoubtedly have gone higher had there been additional space. This high temperature was registered at Agra, Delhi and Jaipur. The night and shade temperature on the whole trip from Calcutta to Bombay ranged between 92 to $105 \mathrm{~F}$. The Bombay weather was very much like that of Calcutta, rain and humidity, but the temperature was a little lower and necasional breezes diminished the sweating and relieved the intense sense of heat.

All throngh India the absence of a breeze made the heat distressing. Some days about 4 o'clock in the 
afternoon a slight agitation of the atmosphere wou!d begin, enough to shake slightly the leaves of the omnipresent nim trees and would bring with it a decider relief, but even this slight attempt on the part of the atmosphere to counteract the effeet of the burning sun was alway's of short duration. It was interesting to observe how the animals, wild and domestic, behaved during the hottest part of the day. The water buflalo is a great bather and he is not particular about the nature of the bath; if he has any preference, it is for the mud bath. In passing the many water and mud holes along the line of the railroad, I have often seen through the car window two long, flat, reclining horns and a pair of sleepy or closed eyes just above the level of the mud or water, and in looking closer might dis. tinguish back of them the ridge of the spine, the l:a!ance of the body being completely immersed. 'The buffalo has three objects in view when he goes bathing: To rid himself for the time being of pestering insects, to gain relief from the intense heat and to obtain a soothing rest after his liberation from the hard, i) imsitive yoke. Sometimes we saw a herd of these animals closely packed in a small pool or mud hole. They are peaceable, tolerant animals, so that even when standing space is scarce, these animals of burden make room for each other without the slightest indication of selfishness. I fancy that the water buffalo prefers mud to water for his bath, for it leaves a thick layer of mud on the surface of his body, which soon dries into a crust, a further protection against flies and mosquitoes. The bullocks, sheep and goats seck the shade of trees during the hottest part of the day, and if the trees are few and the animals numerous, every inch of it is made useful, and, as the shade moves, the family of animals shifts in the same direction to protect themselves against the scorching rays of the sun.

The proud, wild peacock, so numerous all through India, but more especially in the eastern part, forgets 
for a time his vanity when the sun is in a position to send down on poor India its most scorching rays. He folds and hangs his gaudy tail and sneaks away into the shade of a clump of shrubs or cactus hedge and lowers his microcephalic head with half closed eyes in obedience to his majesty of the day. India swarms with turtle doves and the telegraph wires are their favorite perch. In many stretches of the country from one to a dozen of these tidy, innocent birds can be seen perched on a wire betwcen two telegraph posts as the train rushes by. When the temperature rises to $130 \mathrm{~F}$. and more, the wires become too hot for their tiny red feet and they are driven by the heat to find, protection in the shade.

Man appears to possess the greatest resisting power against heat. The coolie, bareheaded or with a few rards of cotton cloth wrapped about his head in the form of a turban, can be seen at work any time of the day, no matter what the thermometer may say. From early morning until late at night he toils in the fields, plowing, sowing, harvesting, or dipping water. as the case may be, to earn his scanty livelihood. In many parts of India the month of September is the most trying one. My guide at Delhi called it the "sickness month," and informed me that during this month few escaped fever, which would last from one to several days. I presume a mild form of malaria.

The insects were not so troublesome as I expected. At Jaipur the flies were numerous and aggressive. In the hotel at Calcutta I found my bed screened with mosquito bar. As the evening was extremely sultry and as I heard no mosquito music, I remored it. Next morning I found the uncovered part of my body checkered with ugly mosquito bites, the noiseless minute mosquito had deceired me and wrought the mischief during the few snatches of sleep that came to me that awful night. I am glad that I have seen India at its worst, so far as the climate is concerned, and that I have escaped with my life, and my health unimpaired, 


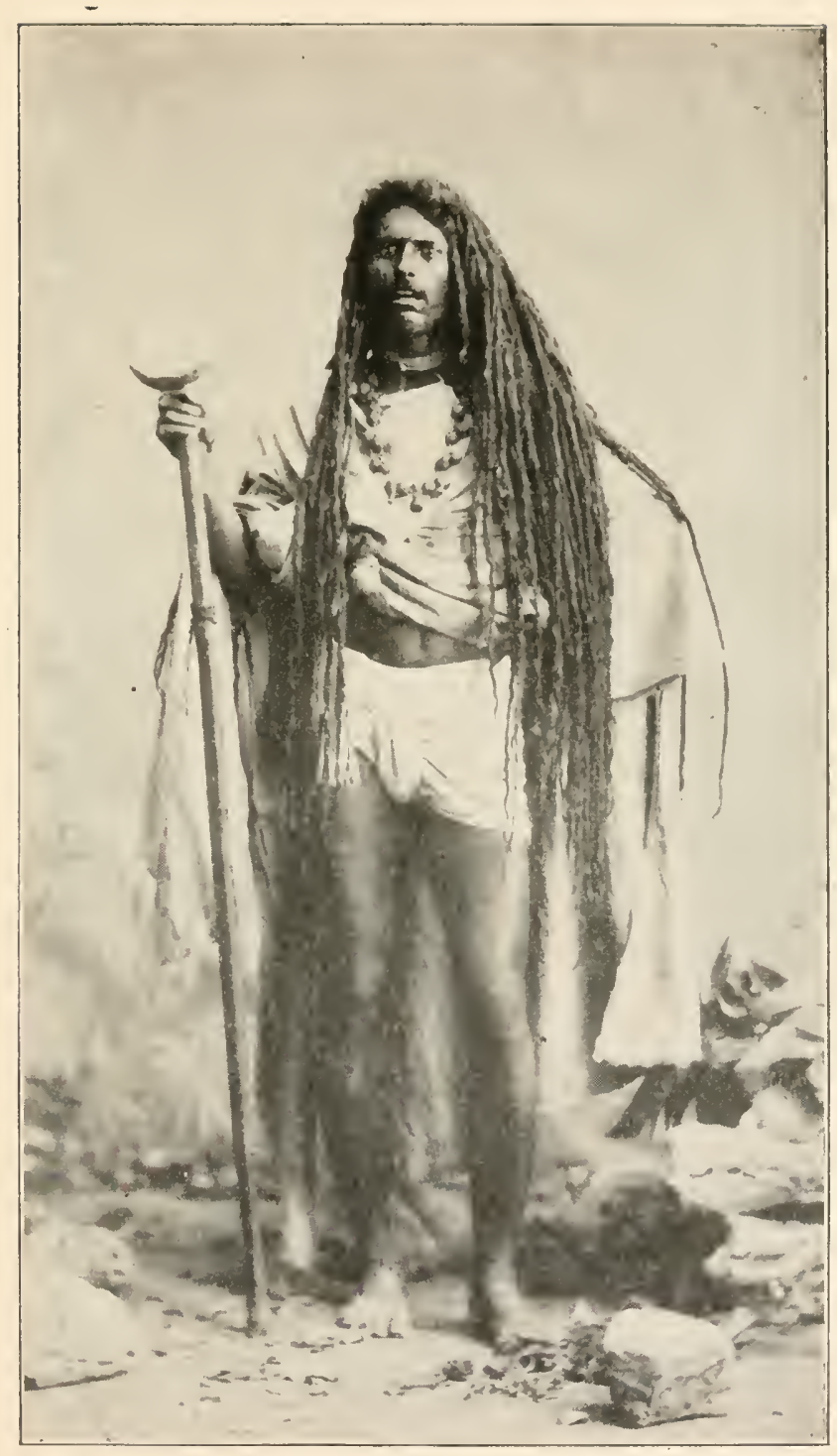

Fig. 56.-An Indian faquer. 



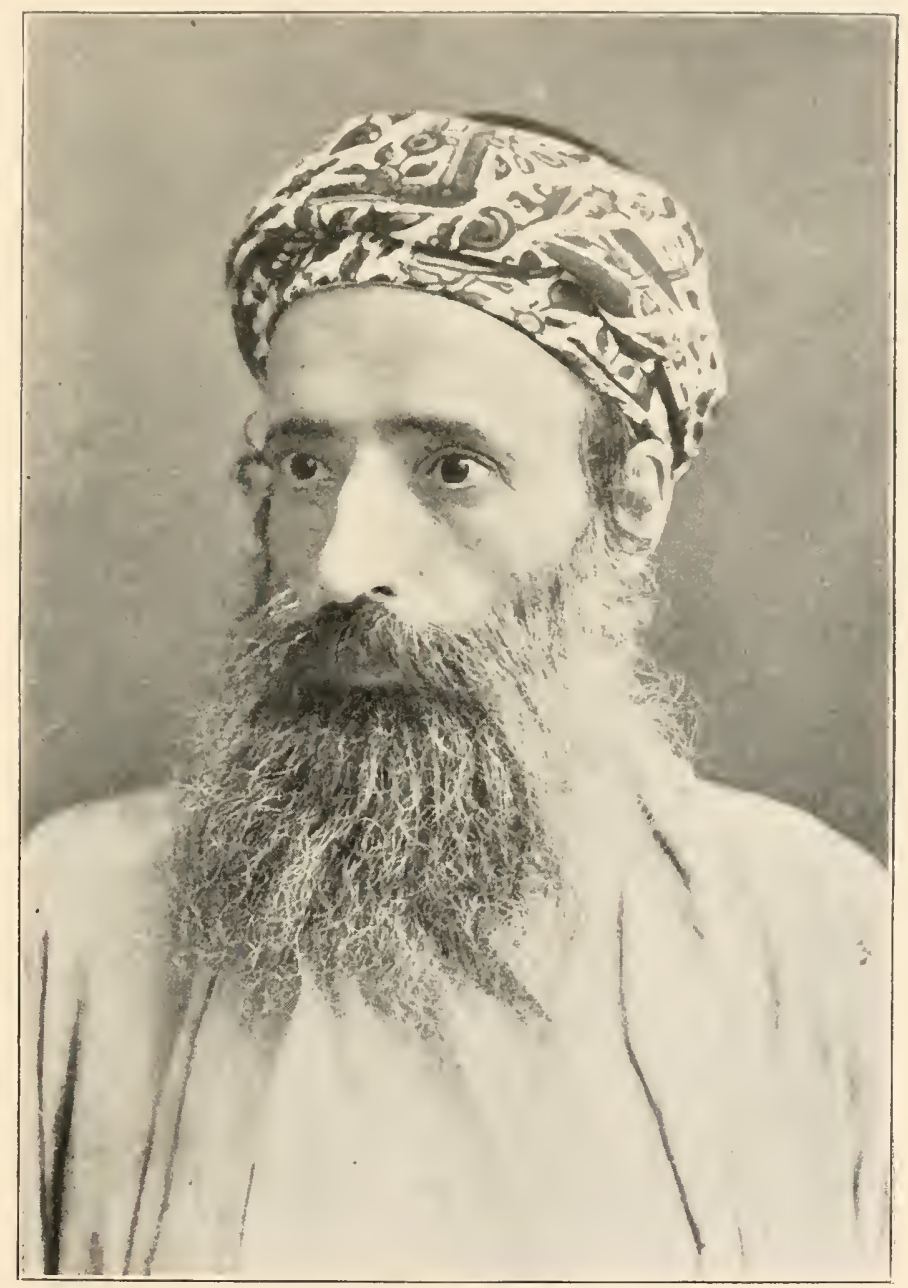

Fig. 57,-An Arab Jew in India. 

but 1 will never advise any of my friends to go through a similar experience, as it involves great suffering and is attender by no ineonsiderable immediate and remote risk in life.

\section{THE PEOPLE.}

India has, approximately, 300,000,000 inhabitants, four to one of the United States The population is a very mixed one, composed of Hindus, Afghans, Mohammedans, Parsees, Thibetans, and other Asiatic races, Europeans and Asiatics, called here Eurasians, in Ceylon half-castes. The original East Indians were an Aryan race, which came from Central Asia by way of the Cabul river. The present Hinitu race represents Aryan and non-Aryan elements. The typical Hindu is above arerage size, fine, erect, slender physique, long, very thin legs and arms, straight black hair, beard of the same color, light or heavy. The color of the skin varies from rellow to coal black. (Fig. 50.) Many of the men are handsome; others, especially the common coolies, are often not only ngly but absolutely hideous, their faces approaching the appearance of a monkey rather thar that of a man. The women are homely almost without exception; much smaller than the men and very spare even during old age.

The handsomest men and women are found among the Parsees, the fire worshipers, who eame from Persia to India centuries ago. They are a thrifty people, fond of dress. The men wear a very strange head covering, which does not answer to the description of either a hat or eap. Imagine a black piece of stovepipe a foot in length, speckled with minute yellow dots, and turn in the top obliquely and you have as complete a description of the headdress of the Parsee as can be given in words. The women are dressed in flowing silk of rivid colors, and display a wealth of jewels attached to ears, neek, fingers and wrists. Bombay is the center of the Parsee population, about 100,000 in number. Their principal temple and ghastly graveyard are located here. 
Social distinction is drawn in India in more definite lines than in any other country. It is a land of castes. There are more than 1,000 of these eastes, which have very little in common with each other. The Brahmins or priests take the first rank, the warriors the second, and the merehants the third, then follow the different professions and trades. The easte of warriors is the only one which is permitted to hunt and to eat meat. There is never an intermarriage between a high caste man or woman with a lower caste woman or man, but in exceptional cases a promotion from a lower to a higher caste with all privileges belonging to such advancement may take place. 'The lower castes made themselves known by stripes and dots of all colors and designs on the forehead or face. A study of these distinctive marks would prove a very thankless task to the foreigner owing to the endless number of castes.

The religious life in India is as mixed as its population. In 1891 there were $20 \%, \% 31$, $\% 2 \%$ Brahma followers, \%,131,361 Buddhists, $.5 \%, 321,16+$ Mohammedans, and only 2,284,380 Christians, a rather discouraging showing for the millions and millions of dollars that have been spent in efforts to christianize the people. The slow progress of Christianity in India is due, at least in part, to the character of the people. The complicated class distinction is one of the greatest obstacles. The high caste Hindu prides himself on the antiquity of his religion. He is firmly convinced that:

"Antiquity, the nearer it was to its divine origin, perhaps perceived more clearly what things were true."-Cicero.

A high-caste Hindn, a very learned man, a magistrate in one of the eastern districts of India, expressed himself to me on this subject abont as follows: "My religion is the oldest in the world. It was old before the religion of the Christians was known. I spent five years in England. I made careful observations and in consequence came to the conclusion that my people are better people than the people $\mathrm{I}$ observed in Fngland. 


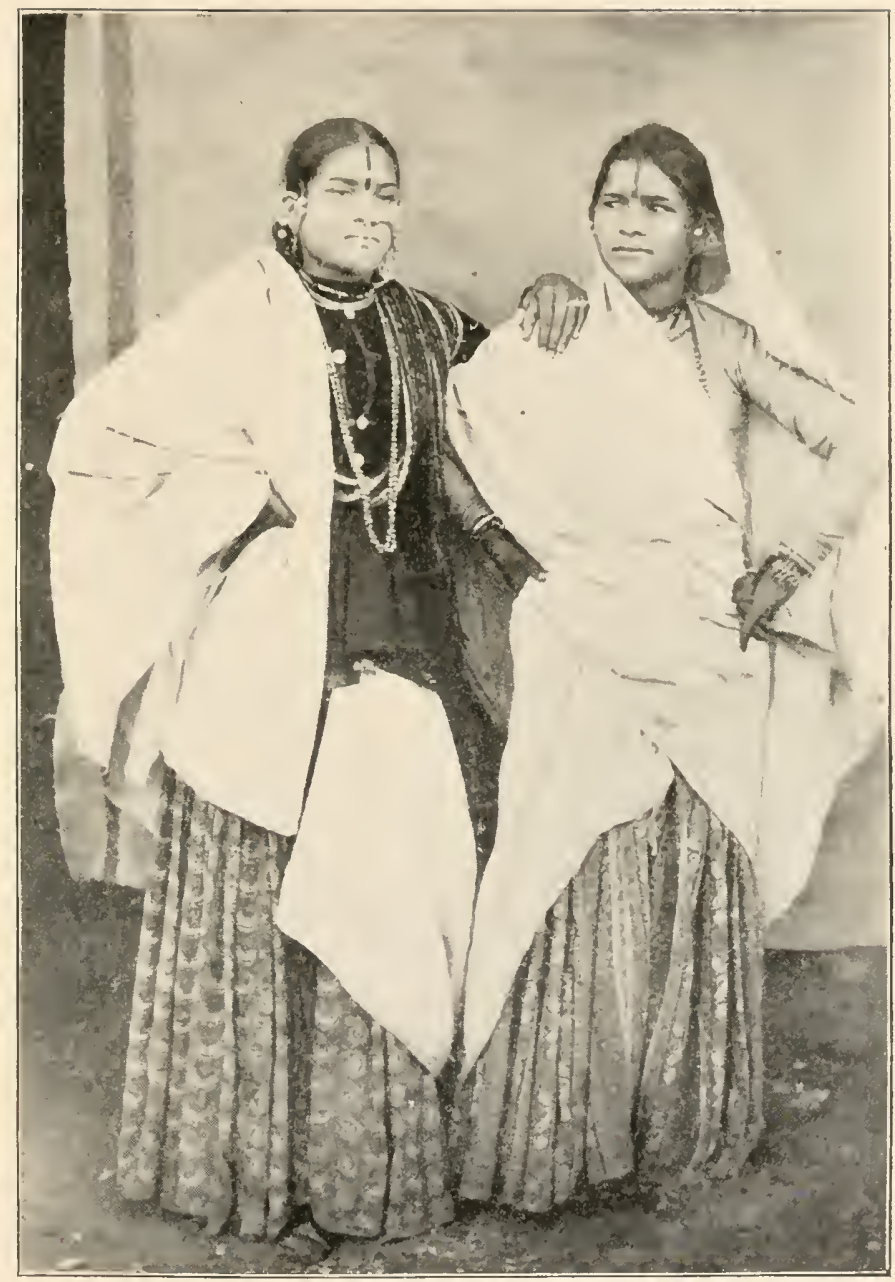

Figure is. 

Crime is more common in England than in India. Why should I change my religion? The essence of our religion consists in leading a useful, pure life. We believe in progression in spiritual as well as in worldly affairs. As the muscle is strengthened by exercise, so constant efforts to reach a higher spiritual existence will improve progressively the spiritual part of men until perfection is reached. We do not believe in perpetual punishment after death, but in a gradual elevation until nirvana, a state of perfection, is attained. Missionaries can not change the religious views of high caste Hindus. Then, too, the manner of living and the way in which the missionaries approach the low caste Hindus are not calculated to excite their interest or to gain their confidence." This is what the Hindu said.

In conversation with me a Roman Catholic priest who came to India 26 years ago said: "We can do nothing with the adults in the way of converting them. The people appreciate our works of charity and our efforts to educate their children. We must plant the seed of true religion in the hearts of the children, where it will grow, but their parents are out of our reach. The ligh caste, educated Hindus have their fixed religious ideas from. which they can not be diverted, and the low castes are in the firm grasp of the Brahmin and the Buddhist priests."

The natives are suspicious of the Europeans and are naturally proud and not easily approached. The poorest of the poor possess an inborn pride and manifest a spirit of reserve entirely unknown among the South Sea Islanders. There is no "Alohanui" or "Talof:" greeting for the stranger in India. 'The faces are stern, the look shy. the bearing defiant and smiles few moles: they are provoked by a liberal tip. The converted natives may conform on the surface with the teachings of the church to which they belong, but in their inner life they retain much of what they have been taught, and what they practiced before they changed their re- 
ligious views; we can say of them as well as of their heathen brethren:

"Some are good, some are middling, the greater part are bad."-Martialis.

"Habit has prodnced the custom."-Ovidius.

Jissionary work has done more good in supplying the starring with food, the sick with nursing and with medical treatment, the poor with clothing and in the education of children than in the christianization of the people. The door to the heart of the Hindu is charity.

The greatest virtue of the coolie is his willingness to work. It is the coolie who cultivates the fields, loads and unloads ressels and cars. cleans the streets, empties the cesspools and performs all other menial work, for wages which range from 8 to 32 cents a day. He has held his place in the competition for cheap labor against Chinese and Japanese, and against cheap workmen from other parts of the world. He meets the demand for labor in India and the low wages with which he is content have so far effectually prevented outside competition, and owing to the dense population and the severe struggle for existence which are in evidence everywhere, preclude the idea of a possible betterment of the condition of the laboring classes. The coolie has no desire to acemmulate wealth; he is satisfied if by hard toil he is able to keep the wolf from the door. His needs are few. and what many a Chicago family spends every day for newspapers will support himself, his wife and children. From experience he can say:

"Ye immortal gorls, men know not how great a revenue economy is."-Cicero.

\section{TNDTI ART.}

Tndia is a groat art musemm. The ancient palaces. tomples and tombs are the silent witnesses of the exquisite workmanship of native artists. who lived and worked her centuries before Solomon's temple was built. The masonry of many of these remmants of ancient architecture is the wonder of the leaders of the craft to-day. 


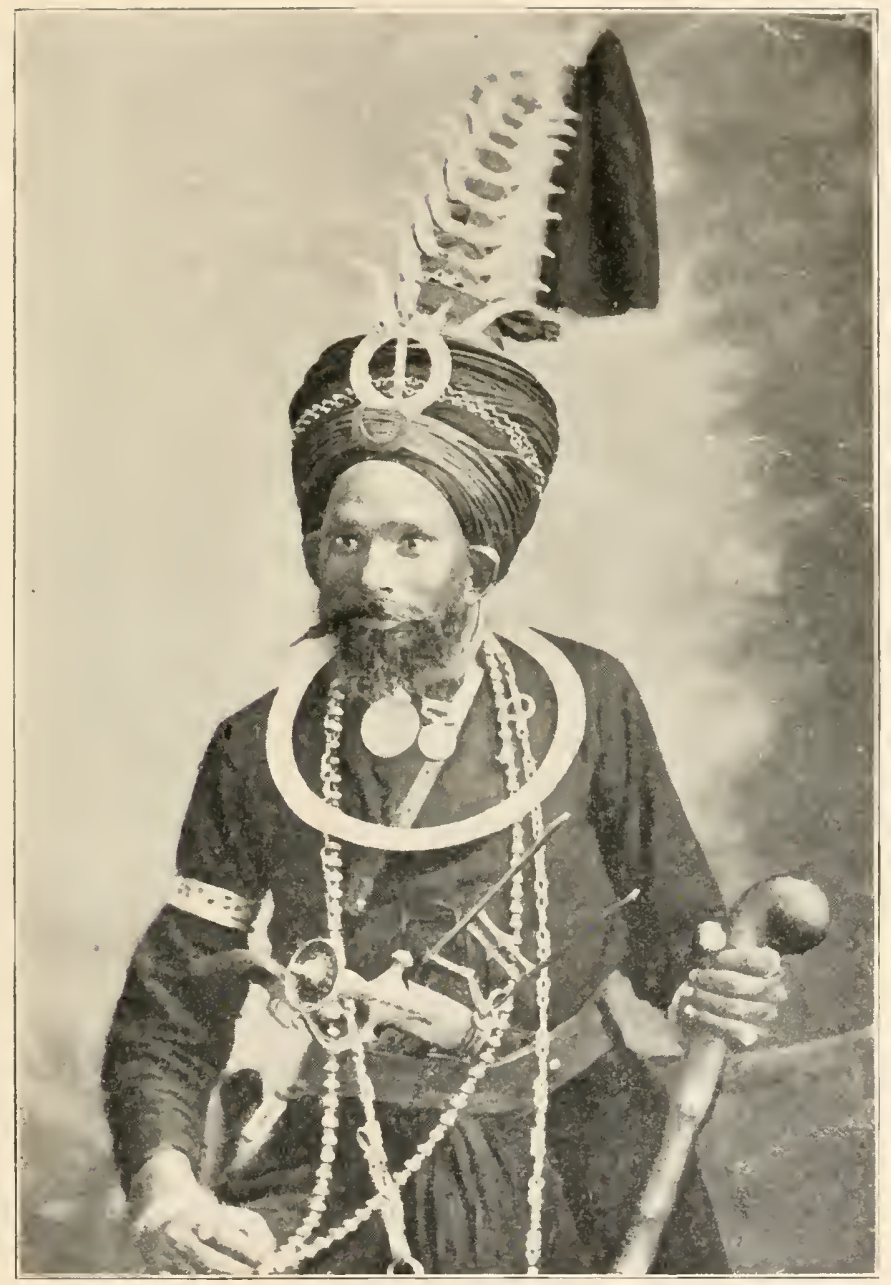

Fig. 59.-A Sikh Priest. 



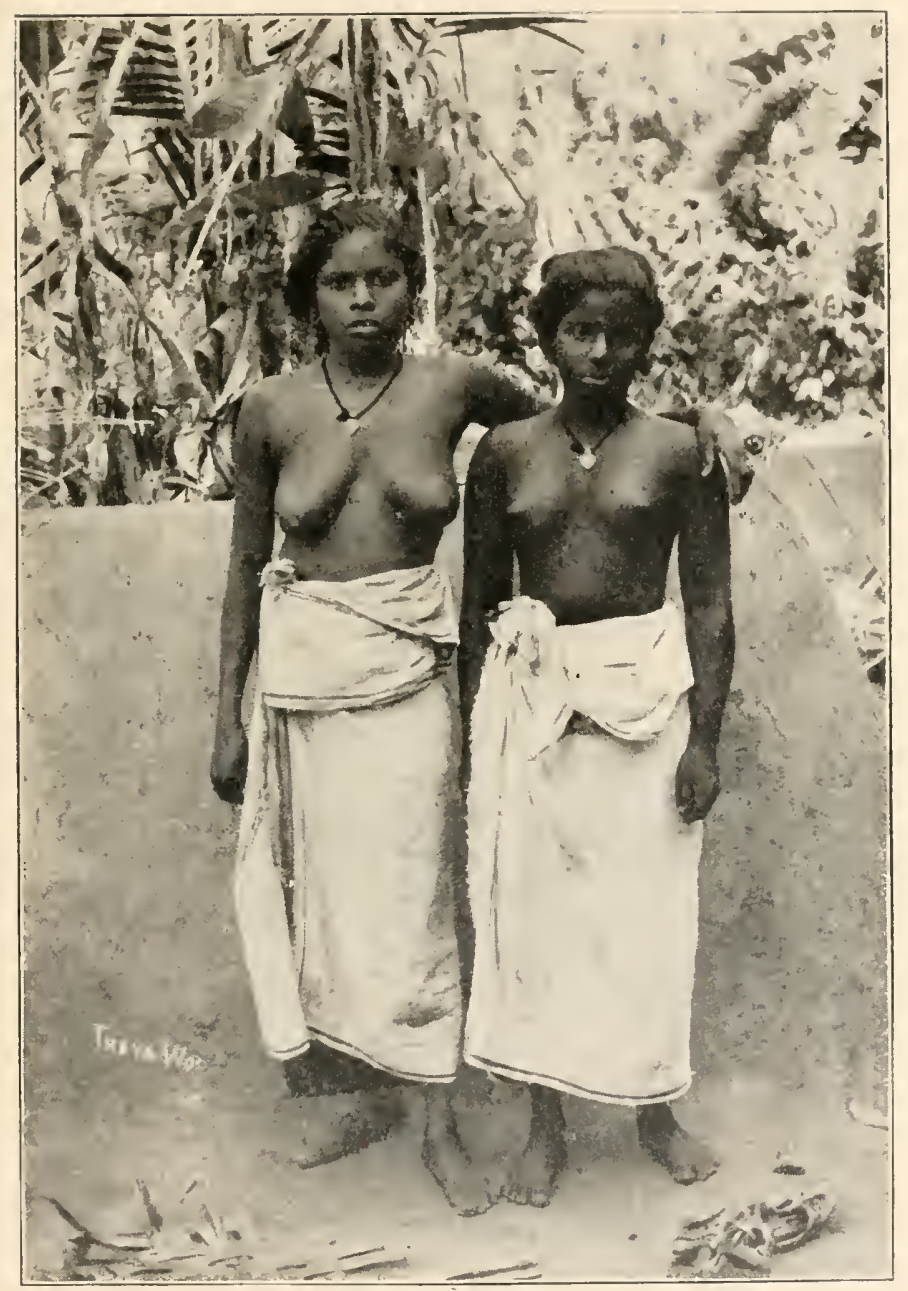

Fig. 60.-Low Caste Mindu Girls. 

'The size of the stones, the cutting, placing them in position, the fitting them together with such accuracy that cement of any kind was superfluous, in other instances the fitting together with metallic substances, are lost arts. 'The designs of the mosirics, the sculpturing and the wood carvings, the inlaid work are marvels of skill, patience and persererenee. 'The ancient artist and artisan made use of nohle material on which to stamp indelibly the proofs of his skill. In short, nature supplies the material, art works on it.

"Art can effect nothing without material, yet there is an inherent value in material, though untouned by the art of man. Perfection of art is superior to the best material."-Quintilianus.

Symmetry was above everything else the object of the ancient architecture, mosaics, columns and arches were the details in carrying out his designs. The two pieces of architecture and design that impressed me most were the royal tomb, Taj Mahal at Igra and the Cave Temple in Elephanta Island near Bombay, the former noted for its exquisite beanty, the latter for its great age and wonderful mural statues, cut out of the lard rock, to which allusion will again be made further on.

It is a source of great regret that the influential and rich natives take so little interest in the preservation and maintenance of their works of art, which after all, are the great magnets that attract thousands of visitor's to India annually. Palaces and palatial residences are now being built in imitation of what they have seen abroad. Painters from Italy and France do the decorating. Plush and silk covered furniture is brought from Europe, and the old beautifully carved chairs, tables and other articles of furniture are stored away, sold for a song or given away to make room for things that are not adapted to the climate and that can malie no pretention to art. It is very fortunate that Lsord Curzon has taken the necessary steps to preserve Indian art by the erection of a great museum of art in Calcutta, in blessed memory of the late Empress Victoria, where 
the most valuable and interesting specimens will find a permanent resting place for the benefit of future generations of natives and visitors.

It is high time that in the three great cities of Calcutta, Bombay, and Madras, associations of Indian art should be founded for the purpose of collecting and preserving specimens of ancient Indian art, and with the object of encouraging the native artists of to-day by patronizing them instead of importing furniture from foreign countries and imitating the artless style of the huildings of the Europeans. For the benefit of natives as well as of travelers, India should remain specifically Indian in dress, customs, agriculture, and especially in art.

NOTABLE MEDICINAL TREES OF INDIA.

On landing at Tuticurin I came face to face with two trees that I never lost sight of on my long railway journey-the palmyra paln and the nim tree. The pahnyra pahm (Borassus flabelliformis) is a hardy, noble tree, and attains a beight of 100 feet. The base of the stem is large and gradually tapers into the stem proper. which has a uniform thickness up to the very crown. The bark is almost black and indented with circular rings. The crown of fronds is small compared with the size of the tree. In southern India the leares are used for roofing, and nearly all the trees have been pruned down to six or eight fronds. The pulp of the fruit serves as food. Enormous masses of sugar and toddy are produced in India from the sap which flows from incisions of the stalk of the unexpanded flowers. This tree is noted for its longerity, and trees 200 years old are by not means rare. The Mohammedans are supposed to be total abstainers, but not invariably so, as I learned from a little story related to me in India. A man who owned a number of these palm trees, and who had bled then for the purpose of supplying himself with the much cherished toddy, noticed that much of 


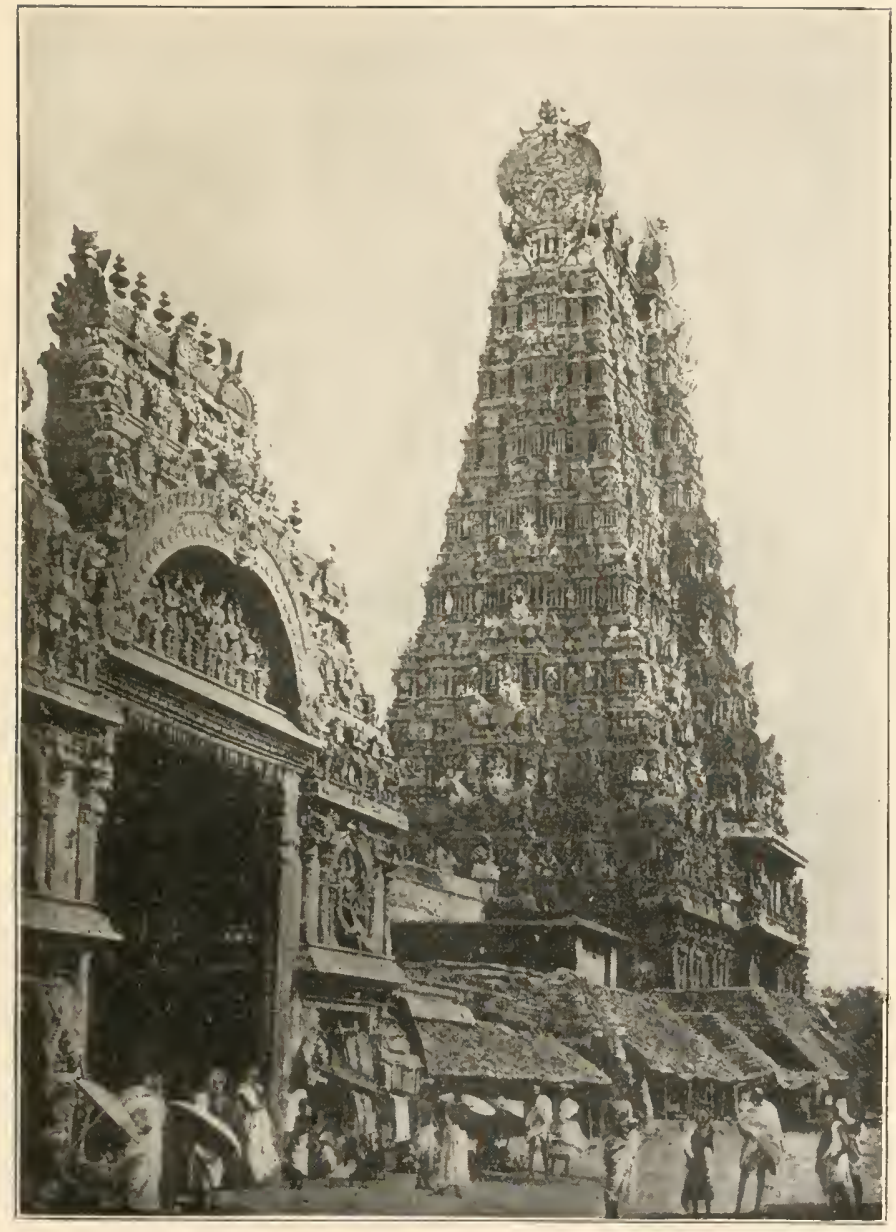

Fig. 61. - An Illustration of IIindu Architecture. 



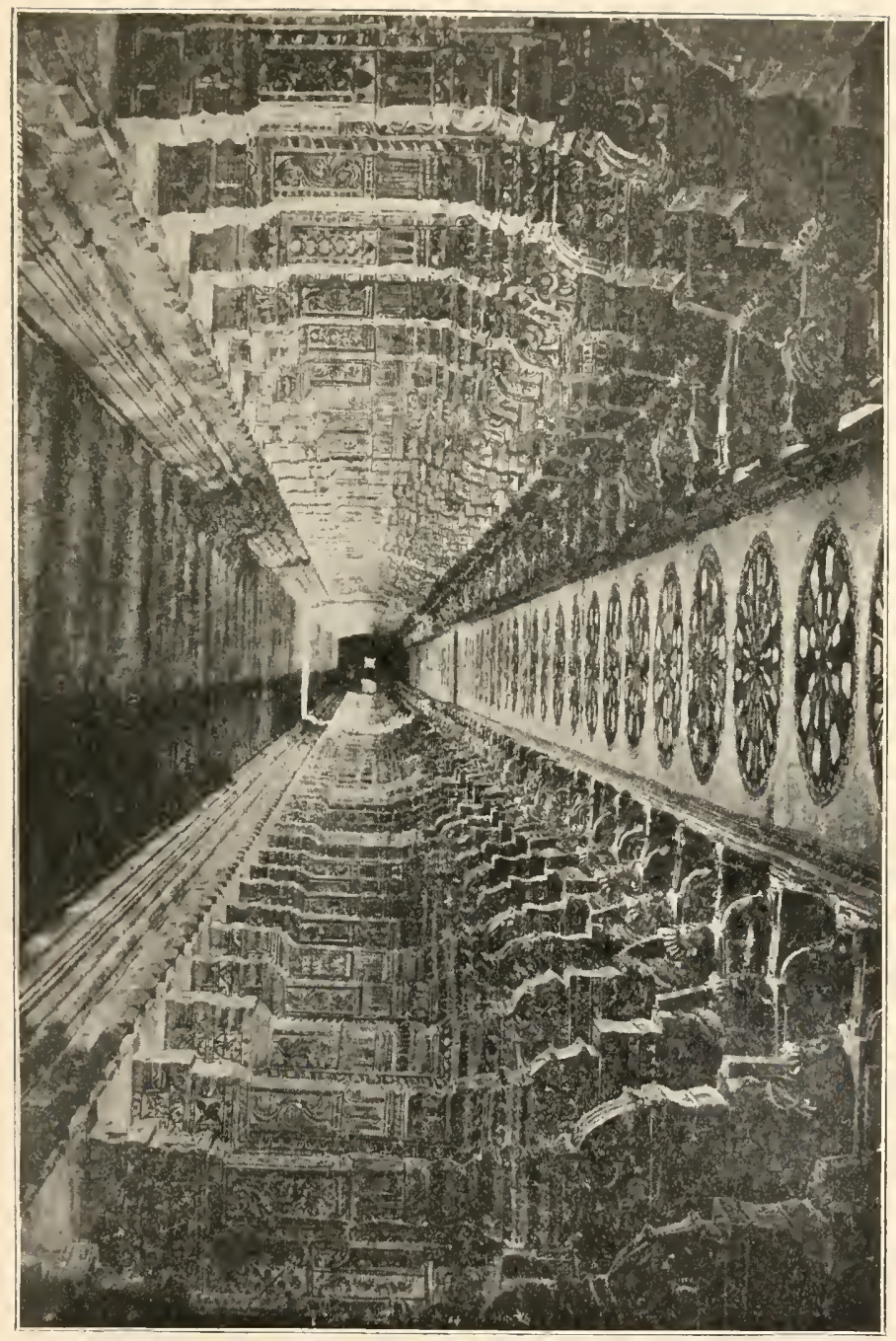

ह 

the precious juice disapfeared mysteriously during the night. Not snsperting that the pilfering was done by human beings he poured tincture of aconite into the cuts into which the sap acemulated. The next morning on roing for his toddy he found to his ntter astonishment two followers of the prophet lead near the tree and sereral more very sick in an adjacent thicket. For obvious reasons a judicial investigation was not applied for. The leaves of this palm have been nsed for centuries as writing paper.

The nim tree (Melia azadirachta) is one of the most beautiful and useful trees of India. It attains a height of 50 feet. has a short. black barked stem. strong, widely spreading branches and a dark, fresh green, rich foliage of long feathery leaves. At Jaipur I saw a boy climb one of these trees, and with pruning scissors serer enough of its leaves to feed a flock of sheep which had gathered around the base of the tree, anxiously awaiting the expected fodder. The leaves have a great reputation as a remedy for drsentery and malaria. Many wonderful stories have I heard concerning the curative powers of a decoction of the leares of the nim tree. This popular reputation is sustained by the medical profession.

The tamarind (Tamarindus indica) is a magnificent, large, expansive tree. It is one of the largest trees of southern India. In immense tamarind tree is in the court of the monkey temple at Benares, and it is in this tree that the monkeys take their gymmastic exercises. The monkeys are anxionsly awaiting the ripening of its fruit. The acid pulp of the long pods forms the medicinal tamarind, rich in formic and butyric acid, irrespective of its other contents, cold made into a syrup, it can be kept for preparing a palatable acidulous drink.

The bábal or gum arabic tree (Aracia arabica) is a very common tree in India. It is a small tree and is usert sometimes for thorny hedges. Occasionally the -tem attains a circumference of 10 feet. It furnishes 
one of the best kinds of gum arabic for medicinal and technical purposes. Cattle are fond of its leaves. The wood is hard and durable, and the pods and bark are llsed for tanning.

One of the most interesting trees to be found in India, although without medical interest, is the banyan trer (Ficus bengalensis). While at Caleutta I made a special pilgrimage to see the famous banyan tree in the Botanical Garden, six miles from the center of the city. I label attached to the stem of the mother trec bears the following legend: "This tree is about 135 years old; the cireumference of its trunk, at about $51 / 2$ feet from the ground, is 51 feet, and of its crown about $93 \mathrm{~s}$ feet. It has 464 aerial roots actually rooted in the ground." The sight of this veteran of the Botanical Garden is inspiring. The daughter trees form a eircular colonnade and their interweaving branches a roof under which a whole regiment of soldiers would find an ample camping ground. The mother tree shows signs of far adranced senile deeay, but her offspring have gained an independent existence and will keep her memory fresh for many generations to come. Since I saw this wonder of the Indian forests $I$ have learned that the banyan tree at Ahemabad is still larger and the largest in the world. Had I known this before I woull have intercepted my itinerary at that ancient eity.

For teehnical purposes, the most valuable tree in India is the teak tree (Tectona grandis). It is a superb timber tree. It sheds its very large leares annually. Teakwood is held in the highest esteem by shipbuilders; for the backing of ironelad men-of-war it is preferred to any other wood; also for the panels of coaches and inside finishing of houses, and for various other select purposes. The wood is extremely hard and scarcely shrinks. This wood is sold in London at \$rj per jo cubic feet.

The siris-acacia (Albizzia Lebbech) is a very common and beantion shade tree. It produces also a good 


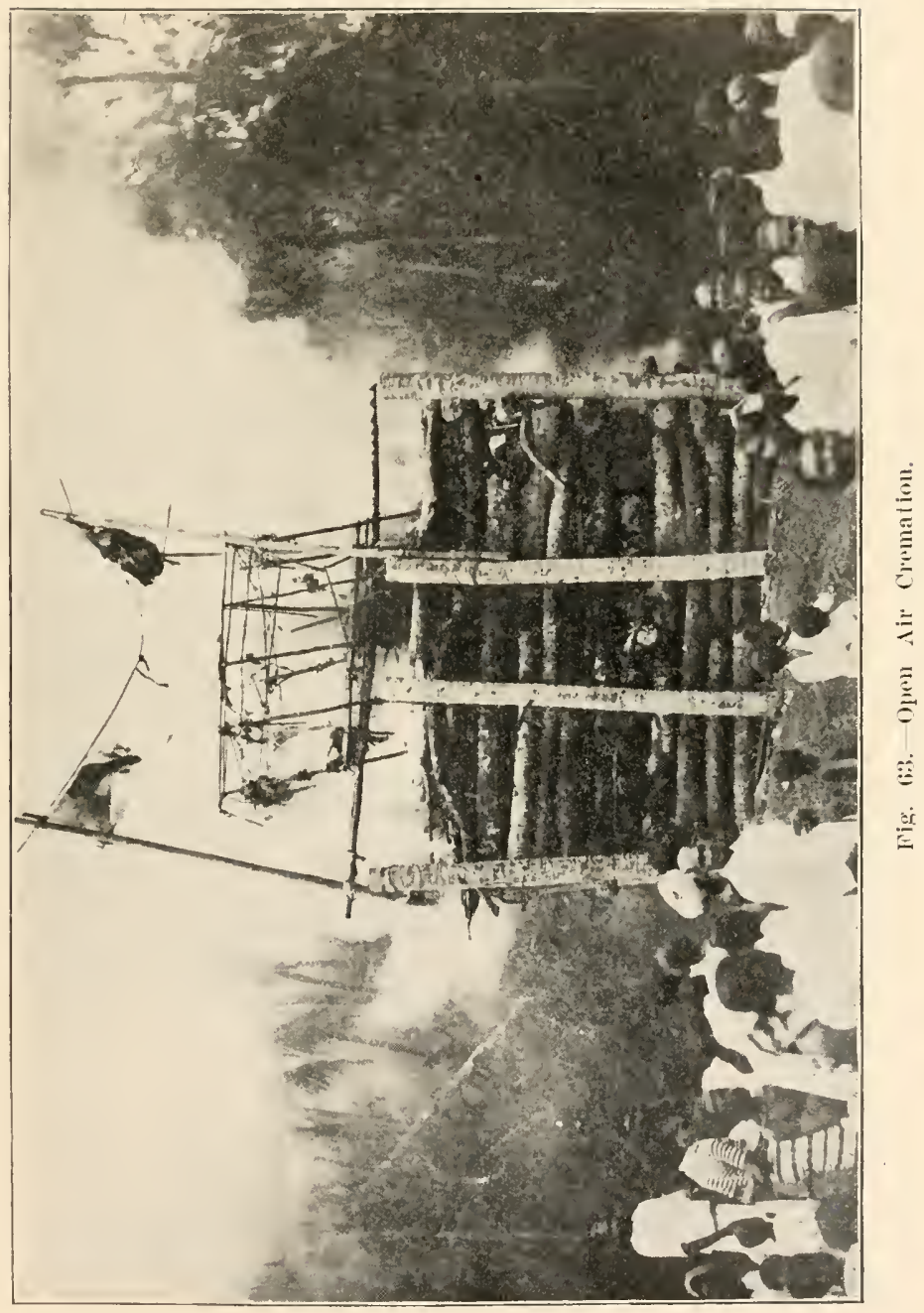



deal of useful gmm. The blossoms are much sought by honey bew, as their pollen is rich in honey-producing material.

\section{MENARLS MONKEY TEMPLE.}

Among the many things which interest the traveler at Benares is the Monkey 'Temple. Within the walled enclosure surrounding the temple is an immense tank which collects the rainwater. From the tank a series of wide stone steps lead to the famous temple. On entering the temple. we were met by the chief priest, Sree Swayam P'rakashhashanand Maithila Auland Bag. the sucessor of the Benares saint recently deceased. His dress did not indicate his high Bralmmin position. It consisted of a loin cloth and a few yards of yellow calico with which to obscure the left arm and a very limited part of the chest. ITis short-cropped, grizzly hair and beard did not add much to his clerical appearance.

The moment we entered half a dozen young priest: who surrounded him howled at the top of their roices. "How, how, how." I thought I had committed a blumler by entering the sanctuary in my mud-stained shoes. This was not the case. It was a priestly greeting and a call for the monkeys. which came rumning from all directions, knowing well that the call meant the arrival of a stranger who would be willing to part with a few small silver coins. with some of which the good priests would buy fond for them which they expected to eat in the presence of the risitor. They had calculated right; their expectations were realized. These miserable, treacherous, thievish, filthy beasts occupy a high position as objects of worship by the Hindus. To maltreat a monkey constitutes, in their estimation, a greater crime than the killing of a coolie. The monkeys in this temple are the same as herds of monkeys in and all around Jaijur. They are very large, gray, with black faces, and tails as long and thick as 
loroom handles. In a few moments we were surrounded by a large crowd of these pets of the priest, with whom they are very familiar. but they mistrust the white man and remain at a respectable distance from him. They eagerly devoured the proffered food, roasted peas and small crackers. The majestic tamarind tree behind the temple was alive with monlicys of all sizes

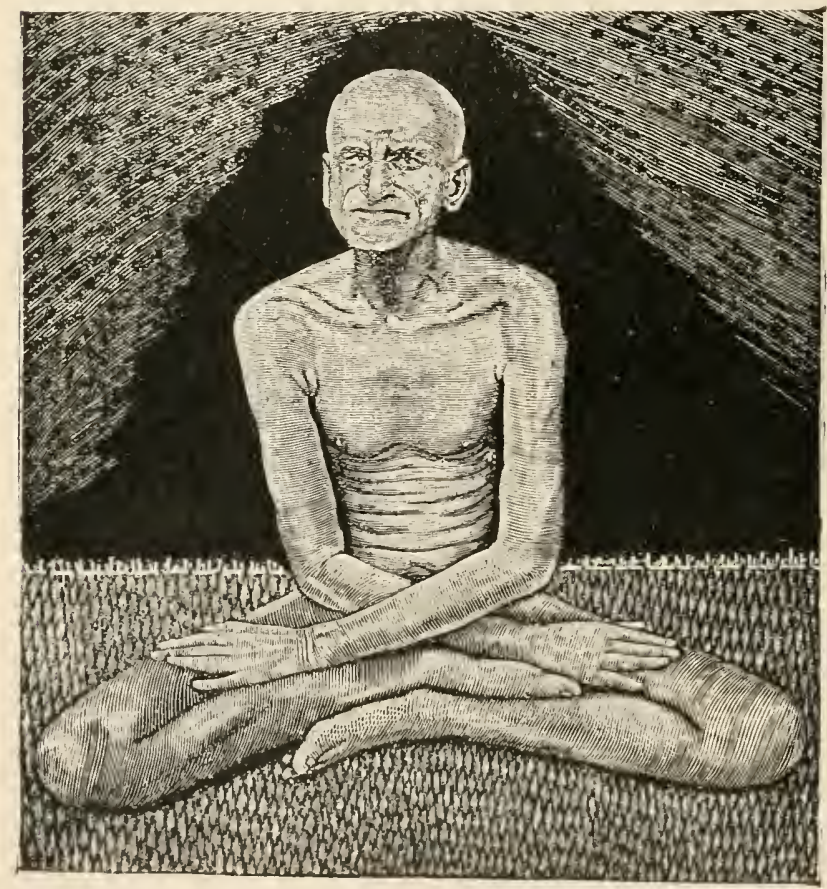

Fig. 61.- Nwami Ihaskara Nand Saraswati, the famous Ascetic of lienares.

amel agcs. Teteran monkeys of doubtful age and baby monkeys on the backs of their mothers, were all equally anxious to be benefited by the liberality of the visitor, as visitors during this season of the year are of rare occurrence. There are more than 300 of these monkey gods in this temple. 


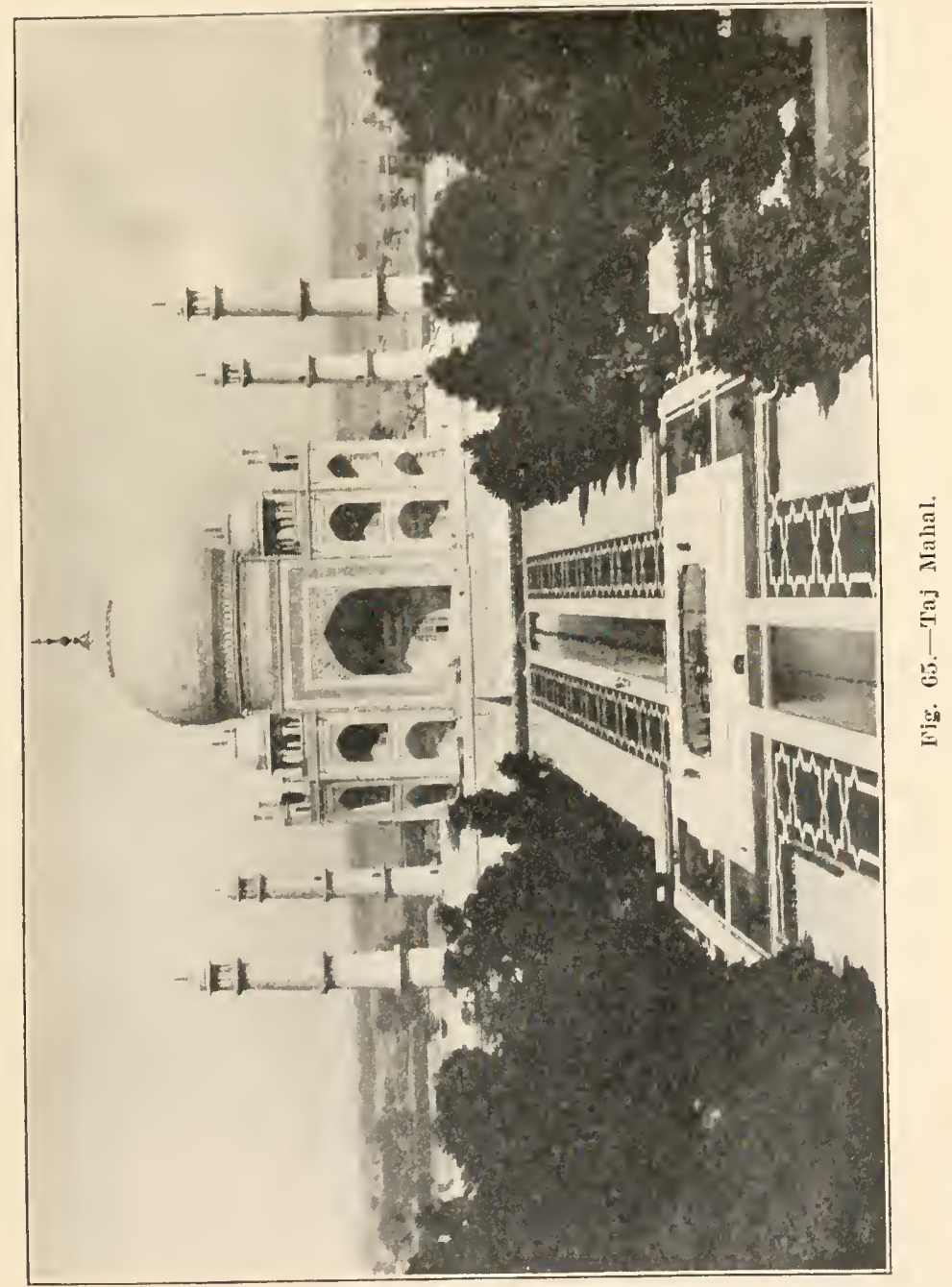




\section{BENARES SAINT.}

The priest to whom I have first referred is, as he claims, the legitimate snceessor to the Benares Saint, Swami Bhaskala Nand Saraswati. (Fig. 6t.) He has the adrantage orer his predecessor in the greater length of his name. 'The saint, or, as his suecessor' calls him, "Holy Sage," died a lew years ago and I visited his plain tomb near the temple. He was for many years a familiar Benares character. His deep learning, plain manner of living and ascetic dispositon made him prominent in the priesthood and an object of curiosity to the visitors. He was born in the year 1833. He was inrested with the sacred thread when he was s years old. He married at the age of 12 but left no issue, althongh a son had been born to him. Soon after the hirth of his child he left his home and wife and deroterl himself to the study of Sanscrit, visited shrines and became known to all as a profound Sanscrit scholar, a philosopler and a real Jogi. His successor says of him: "His dignified mein and renerable face silenced the onlookers who had doubted that a man could learn and practice Ioga at such an early age." And again, "His sonl penetrated into the rery heart of Being, by seeing reality as it is. He was a philosopher to whon God was not merely the creator of this universe. its protector and guide, but the life of his life, the soul of his sonl-his rery self. Such a sage was the Swami Bhaskara Nand-ealn. silent, majestic, immersed in the glory of his omn soul." What an enriable record to leave in this world of sin and corrpution.

\section{IIINDU CREMATION.}

Sitting on the reck of a river rowhoat and gliting down the sacred Ganges near its border on the side of the ancient city of Benares, we passed the principal temple. I saw a number of burning funeral pyres at the very edge of the turbulent, dirty stream. It was too late to see the whole process of cremation as practieed by the Hindus. It was at Igra that I was given 
an opportunity to become a witness of this funeral rite. On the way to the Taj Mahal we passed a small procession, following a corpse carried on a litter of dry bamboo sticks on the shoulders of four men. The corpse was covered with a cloth of bright colors, red being the predominating one. The whole procession was made up of men, 24 in number. Women nerer attend funerals. The procession moved in quick steps and the mourners chanted a monotonous dirge, repeating over and over the same words, which the guide translated into "The name of God is true." Wishing to profit by this opportunity to witness an open-air cremation, I abandoned, for the time being, the visit to the Taj IIahal and followed the procession. The procession continued its march until the border of the Jumna River was reached, where the corpse resting on the bamboo litter was deposited on the ground. I learned that the body was the corpse of a married coolie woman, 25 years old. She was sick 15 days with a diffuse swelling of the face (erysipelas?), and had died at 5 o'clock in the morning of the same day. It was now 9 a. m. Her husband was working in a place in the country, 20 miles from the city, and knew nothing of her illness and death. The only relative present was a brother, a lad about 17 years old, who officiated at the ceremony. The people were evidently extremely poor, so economy had to be practiced in cremating the corpse. The men squatted in a group on the banks of the river, smoked and chatted, and nothing but the presence of the corpse and the materials for building a fire reminded us that we were in the presence of death. The young brother was the only one whose face was earnest and expressire of grief, but not a tear was to be seen. Wood is very expensive in India, $1 / 4$ pie a pound (1/16 of a cent), hence it was used sparingly in this cremation. About two armsful had been procured. A pile of round dry chips, each about the size of a soup plate, was to be the principal fuel. These 


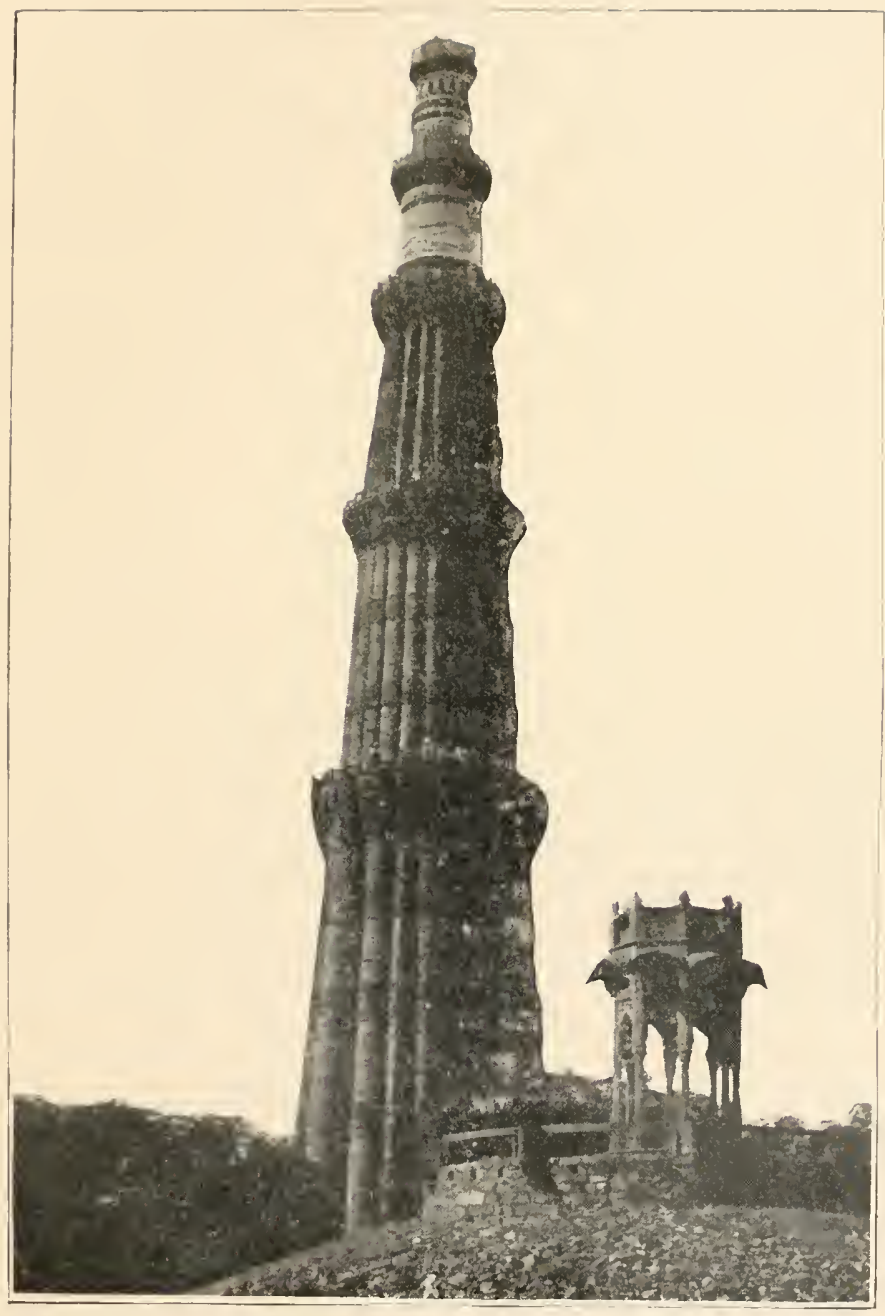

Fig. G(i.-Tower neal belhi. 



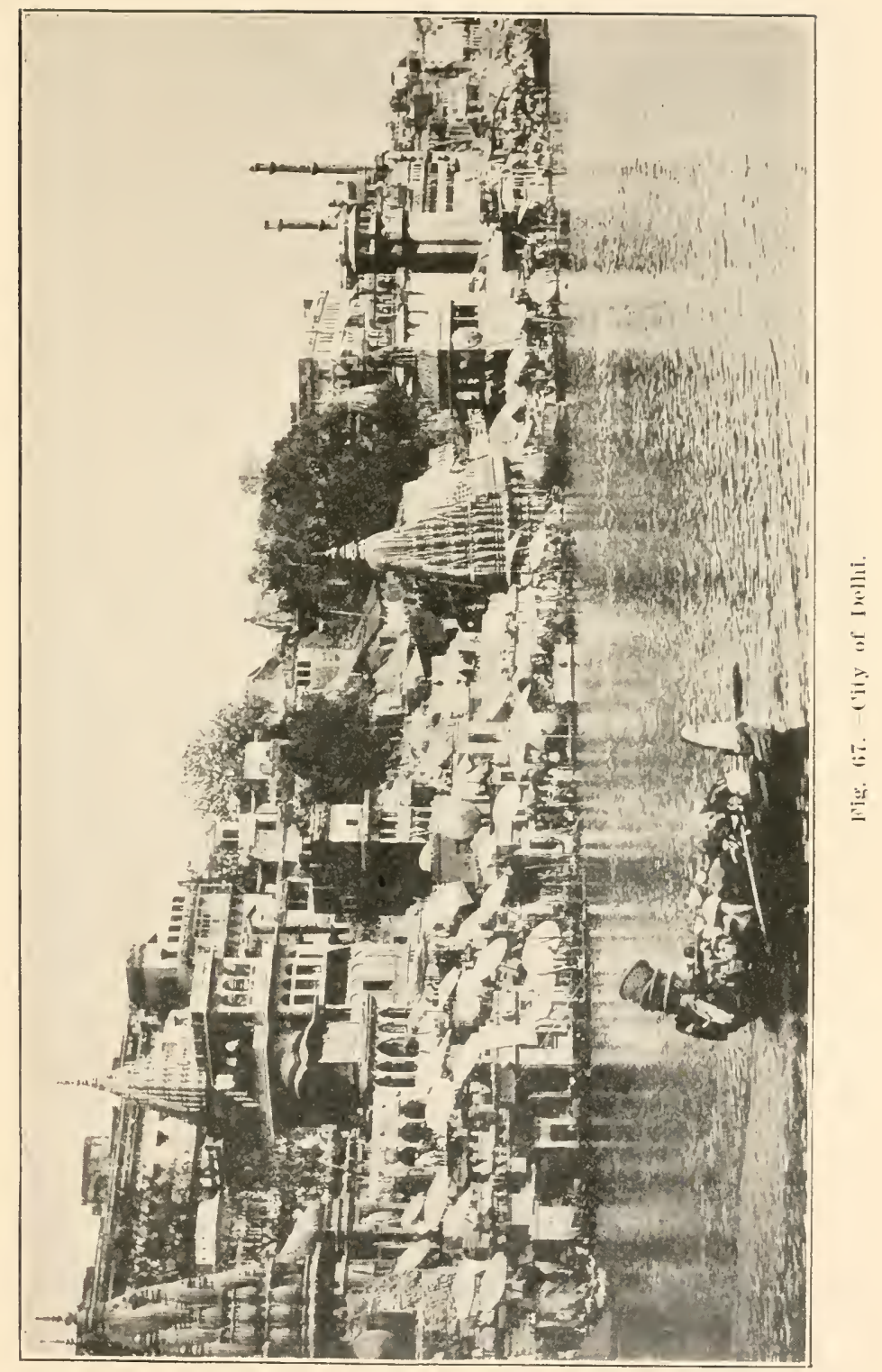



chips are made of stable manure mixed with rice straw. In the soft state, they are attached to walls and the outside of houses, where they are dried in the sun, and are used extensively as fuel. They are the prototype of the "buffalo ehips" of our western prairies. The ground was first covered with several layers of these chips over an area a little in excess of the width and length of the corpse; pieces of dry wood were then laid across. (Fig. 63.) The body was then prepared by the brother; the highly colored cloth was removed; the face was wrapped in a cloth and was never exposed while the brother washed it with water dipped from the nearby Jumna. Next the glass bracelets were broken with a piece of wood. The body, in a cheap, well-worn calico dress, was placed on the layer of woot and, lastly, chips were piled on all sides and over the corpse. A small bundle of dry brush was then purchased, for four annas, and distributed over the sides and top of the small mountain of chips. A handful of rice straw was then taken from the litter, twisted into a torch, ignited by one of the old men, swung by the brother until it burned in a bright flame, and with this the dry brush was set afire at the head of the corpse. The breeze was in the right direction, and in a few moments the entire pile was ablaze, the chips canght fire and soon the odor of burning flesh escaped with the smoke. It was at this stage of the cremation that I was as anxious to leave as I had been at first to witness it. We left the mourning party jabbering, laughing, smoking and looking lazily and unfeelingly into the smouldering fire maintained by the chips. During our stay, the ashes of the two corpses previously cremated were thrown into the Jumna River. On a knoll overlooking the river a Brahmin priest was perched, awaiting the funcral procession of a corpse attended by mourners who could pay him for his priestly funetions. He did nothing for the poor young woman whose rorpse was now being devoured by the smouldering 
fire furnished by the cheapest fuel. $\mathrm{He}$ did not have to wait long to assist in the happy incarnation of the soul of one of his faith. In returning to the city we met another funeral procession, chanting the same funeral dirge, but to outward appearances the mourners belonged to a higher caste. They were well dressed and undoubtedly expected to pay the priest liberally for his services.

"It is a brief period of life that is granted us by Nature, but the memory of a well-spent life never dies."-Cicero.

TAJ MAHAL.

The Royal Tomb, Taj Mahal, at Agra, is the most costly and the most beautiful mausoleum in the world. It was built by Emperor Shahjehan Jeman for his wife, Bagum. It was commenced in 1629 and completed in 1648 . It is the most significant landmark of the power, glory and wealth of Turkish rule in India, and Agra to-day is a very important stronghold of Mohammedanism in India, as one-half of its population of 150,000 are Mussulmen. How so much money could be spent in memory of even a beloved empress surpasses all understanding. (Fig. 65.) The entrance to the building which contains the tomb is a specimen of exquisite architectural art. From the entrance a pathway, paved with the purest white marble, leads to the main building, lined by columns of the same material and on each side a row of arbor vitæ, the tree so constantly found in Mohammedan cemeteries.

\footnotetext{
"Thon must leave thy lands, house and beloved wife, nor shall any of those trees follow thee, their short-lived master, exeept the hated cypress."-Horatius.
}

The passage between pools and fountains and lovely flowers and shrubbery up to the steps of the magnificent marble building characterized by symmetry and beauty in which the precious ashes of the empress have found their last resting place, is unequaled in the world for its exquisite architectural design. The real tomb is in 


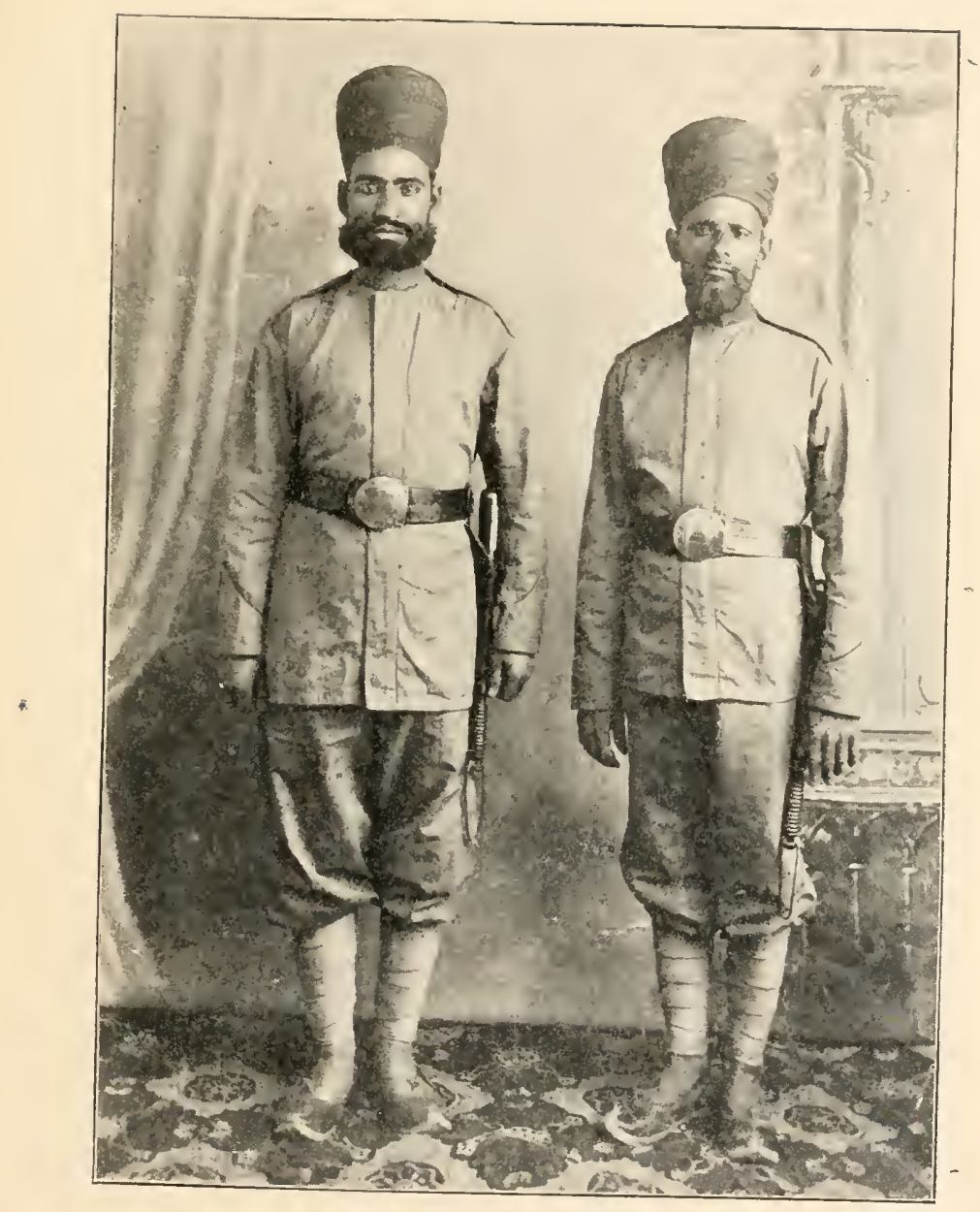

Fig. 68.-Native policemen. 

the basement, side by side with that of her husband. The emperor had planned a separate mausoleum for himself of black marble on the opposite side of the Jumna. The building was commenced on a large scale, but death overcame him prematurely and he now shares the ample space of the mausoleum which was intended exclusively for the last resting place of his wife.

DELIII.

Delhi is unquestionably the most interesting eity in India. I mean by this not Delhi of to-day with its 300.000 inhabitants, but the Delhi of long, long ago with its ruins of palaces, temples and tombs spreading orer a length of ten miles by a breadth averaging a little less than six. In this area are comprised the traditional "seven castles and fifty-two gates" spoken of as far back as 1611 by the merchant Finch. This entire ąrea is literally strewn with remnants of the glory of the Delhi of the past. The palace of the Moguls within the fortress of Delhi is a magnificent specimen of Indian architecture, a combination of symmetry and beanty of design. The road from Delhi to the old town of Qutab, twelve miles distant, passes orer and on each side as far as the eye can reach ruins of former wealth and power come into view. In this great stretch of country millions and millions of people have lived and stmuggled centuries ago when Delhi was the Rome of India. (Fig. 66.) The most conspicuous landmark of ancient history here is the minaret Qutab, 238 feet high, sloping from the foot. Although struck twice by lightning, it remains in a good condition of preservation, a strong reminder of the former powerful Mohammedan reign. The remaining historical ruins of Old Delhi in the immediate neighborhood of the colossal minaret are the mosque and tombs of Altamsh and Adham Khan, noted for their simplicity and architectural beauty. I met here a 
guard, a vative, an old veteran who served under Lord Roberts during the Cabul war. Ile was prond of the decoration he wore on his breast, but, like all other guards in charge of public institutions, his right hand was converted into a big shallow cup for the reception of a handsome tip when I was ready to say goodbye. I took breakfast at the Rest ITouse, kept by a Turk. In view of the nationality of the host, I expected to cnjoy a good cup of coffee. The stuff that was served as coffee was absolutely beyond criticism. I asked to be shown the coffee used in its preparation. I was handed a package wrapped in a yellow paper and containing a pitch black pasty mass. It bore the following delusive label: "Symington's French coffee, prepared as in Paris and blended with the finest chicory." Judging from the taste and smell of the black infusion I. became satisfied that it was made from poor chicory without even a blending of coffee. During our return trip the mercury in the thermometer went up to $126 \mathrm{~F}$.

The Royal Palace in Delhi, within the great fort on the bank of the Jumna river (Fig 6\%), is in a good state of preservation and an imposing example of ancient Indian architectnre. The great temples, old and new. scattered all over India, remind one very forcibly of:

"No nation is so barbarous, no one so savage, whose mind is not imbued with some idea of the gods. Many entertain foolish ideas respecting them, yet all think that there is some divine power and nature."-Cicero.

Their grandeur and beauty suggest:

"There's nothing ill ean dwell in such a temple; if the ill-spirit have so fair a house, good things will strive to dwell within it."-Shakespeare.

\section{A PARSEE TOMAN DOCTOR.}

On my arrival at Jaipur the proprictor of the Rustem Family Hotel informed me that the only other guest in the house was a very distinguished Parsee woman doctor. He said that her reputation has spread all 
over India and that she was well known in the medical circles of Europe. Naturally these statements excited my interest. I was anxious to get some particulars of the medical and surgical work of women in India and to obtain additional information regarding the status of gynecology and obstetries in this country. At dinner she occupied a seat opposite me at the table. She was a woman well beyond blooming youth with a yellow, freckled face, coal black eyes and hair. She was dressed in flowing silk of different colors, with ruby red in the lead, and displayed a profusion of what appeared to me cheap jewelry. She displayed a nervous disposition. She brought a new book with her, which she seemed not to read, but to glance over in a very nervous manner during and between courses. The attention paid to her by the waiters proved to me that she was no stranger in the house. The proprietor of the house was, like her, a Parsee, a fire worshiper. From the appearance and behavior of the woman I became satisfied that I had a colleague to deal with from whom I had little to expect in the way of professional courtesy, and yet a possible opportunity to increase my stock of medical and surgical knowledge from such a rare source was too tempting not to make an effort to obtain it. With many misgivings I made the attempt very cautiously. Nothing but an occasional timid, lightning glance was exchanged during dinner. After dinner I sent my servant to her room with my card. He returned a few moments later with the disconraging information, "The lady is too tired." Disappointed as $\mathrm{T}$. was in receiving this not entirely unexpected news, I had the satisfaction of knowing that I had done what I deemed my duty. The next day I was "too tired," because in the meantime I had ascertained that the much famed Parsee woman doctor knew more about fire worship than medicine. A strict armed neutrality was maintained on both sides during the remaining time we were obliged to live under the same roof 
and to eat at the same table. A red cloth-bound book was her invariable silent table companion. It was not a medical book. It must have been either a norel or some occult treatise on fire worship. Of the meeting with this woman I can not say, as of all other members of the medical profession. that I had the pleasure of mecting on my long journey:

"Friendship, mysterious cement of the soul. Sweet'ner of life and soldier of society."-Blair.

\section{A SICK ELEPHANT.}

From Jaipur I made a trip to the old capital city, Amer, its palace and wonderful mountain fortifications, eight miles distant from the present seat of government of Jaipur state. The old city is enclosed by mountain ridges 1,500 to 2,000 feet high, all strongly fortified. The eity is now in ruins and nearly deserted. The palace and fortifications are in good repair. It was arranged the evening before that I should go by carriage as far as the base of the mountain, where an elephant would he in waiting, who would take me over the mountain ridge to the old city, and from there up the steep incline to the palace and fortification. When morning came I was informed that the elephant was sick and that a bullock cart would be sent instead. In making inquiry regarding the elephant's sickness I ascertained that the luuge beast, quite old, had for several years been suffering at intervals from acute attacks of illness. He would fall down suddenly, with great pain. These attacks would. last from three to four hours, when he would recover and remain in apparently good health until the next attack. I am quite confident that this giant beast is the subject of gallstones of enormons size and that it is only a question of a short time before he will die from a complicating suppurative inflammation of the bile ducts. When we came to the foot of the momntain the bullock eart was conspicnous for its absence. I was determined to see the old city, palace and fortification, and there was no other 


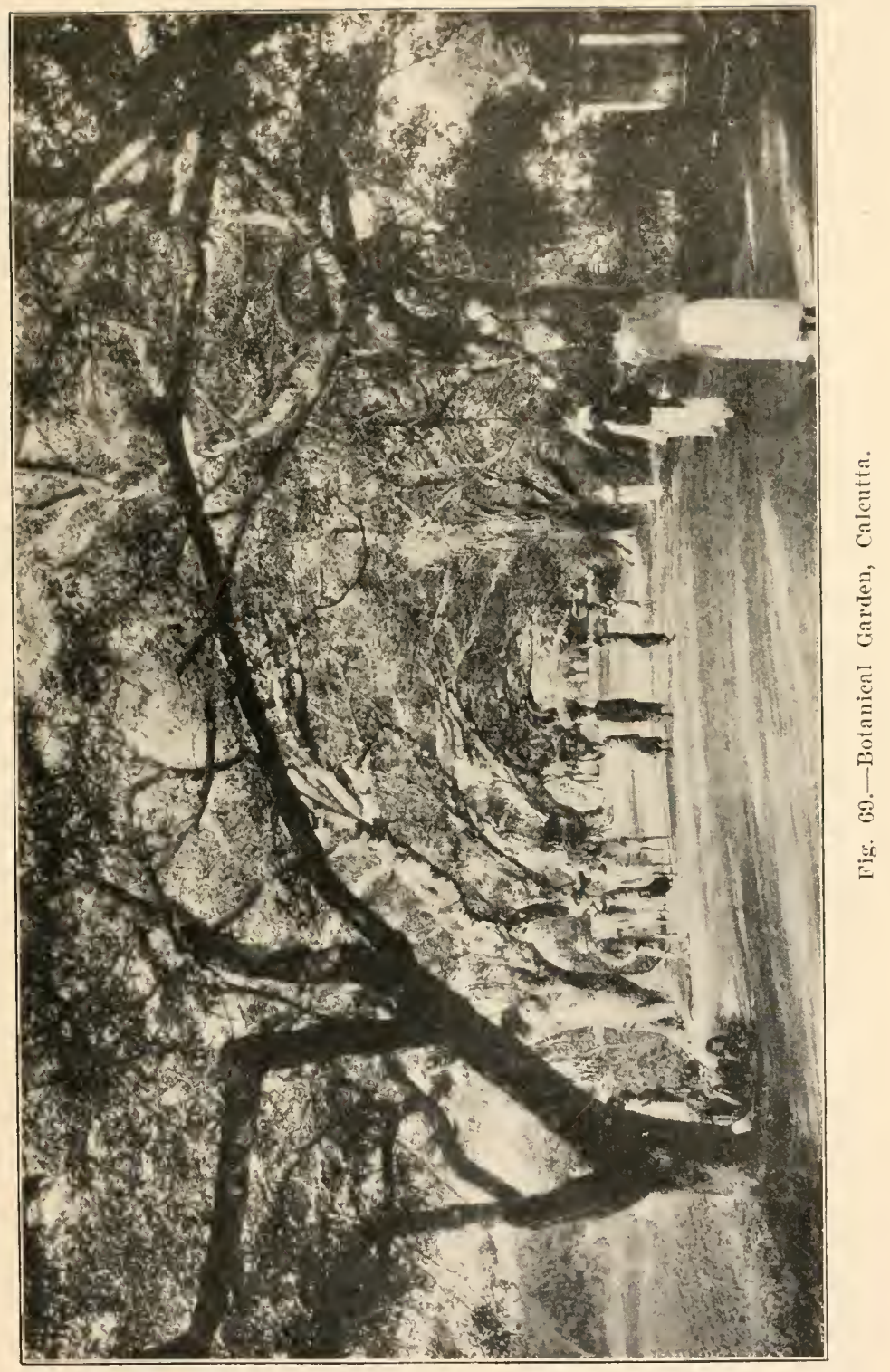



alternative left but to make the trip of two miles and the climb of 1,500 feet on foot in a temperature of $132 \mathrm{~F}$. as registered by my thermometer. It is needless to say that when I reached the palace my clothes were not only wet through and through, but my feet and socks were soaked in sweat that ran down the legs in streams.

After sceing the sights the belated bullock cart arrived, and on it I made the return trip. The cart was a first-class one, but what a vehicle! I first tried to ride á la native by doubling myself up in monkey style. As the springless rough cart jumped over the stones, into and out of ruts, this position soon became unendurable. If it had not been for my inborn pride to surmount hardships I would gladly have jumped out, paid the owner and his old wile, who accompanied us and who helped her spouse in keeping the bullocks in motion, for their trouble, and returned as I came, on foot. As it was. I rendered my position endurable by sitting crosswise in the cart with the numb legs hanging over one of the immense wooden wheels. I made up my mind at the time that as long as I remained in India I would ride on anything else but a bullock cart. It was my first and last experience with this rude antiquated native rehicle.

\section{A CROCODILE TANK.}

In the rear of the palace of the maharajah of Jaipur is a tank covering several acres and containing a greenish turbid water covered for the most part with the scum of algae. It is inhabited by crocodiles and turtles. Stone steps lead down from the palace, to the edge of the water. On the advice of the guide we had brought with us from a nighboring butcher-shop delicacies with which to feed the crocodiles. As soon as we reached the edge of the tank a palace guard commenced to make a barking noise and in a few minutes something appeared on the surface of the water which looked like a black $\log$ about fifteen feet long. The 
scuttling motion of the smaller end of the $\log$ showed that it was a crocodile on the way to accept the proffered invitation for tiffin. Slowly, lazily, the monster approached, and as it came up to the steps an immense inoss-corered head with small slit-like eyes appeared above the surface of the water with the eavernous mouth wide open. displaying two rows of sawlike teeth. With merring aim he caught the fragments of meat, which at once disappeared from the tongueless mouth. In less than ten minutes four other crocodiles and a large turtle were our guests. One of the largest of the beasts, a monster at least twenty feet long. took the liberty to climb the steps in order, I presume, to cultivate a closer aequaintance with us. A few blows with a chb administered over the skull by the guard brought him to a standstill, and with a tremendous splash he returned to his proper element and disappeared from sight.

\section{A BELATED BRIDAI CEREMIONY.}

One Sunday afternoon, while driving through one of the principal streets of Jaipur, I heard the ear-killing strains of native musicians. I brought the carriage to a standstill and a procession soon made its appearance, headed by the band. It was made up exclusively of women, from four to six abreast, each of them earrying on the head a basket containing sweets and other small presents. It was explained to me that this procession was in honor of a woman who in four weeks would make her first addition to the census of the city. It was not difficult to locate the bride of eight months in the first row of the procession. The lusband was not there. He was at loome awaiting the presents from his father-in-law, conveyed to him by the members of the procession. Later in the day I saw another procession on a larger seale announcing to the public a similar erent. This custom, which to me appeared a praiscrorthy one, is generally observed, and 
if the census taker of Jaipur keeps his ears ready and his eyes open, he has no difficulty in keeping track of the increase of the population.

\section{FEAST OF THE NEW MIOON.}

As I was elbowing my way through the crowded streets of Jaipur, on Sunday evening, soon after sundown, I saw thousands of eyes looking in the direction in which the scorching sun had so recently disappeared. I was told that it was the feast of the new moon. It was a long time before I could see the goddess that was the object of worship that erening. I finally could make out the faintest outlines of a pale little sickleit was the new moon. A great procession formed in honor of the event, headed by a native band, a gaudily caparisoned elephant, a squad of police, and followed by a company of native soldiers. 'The moon is held in high esteem as a goddess by both Brahmins and Buddhists, and the new moon is always greeted with joy and heralded by a religious procession.

\section{A FAITHFUL ROMAN CATHOLIC PRIEST.}

At Abu Road a gentleman, plainly dressed, with full beard well peppered with gray, entered my compartment and at once entered into a lively conversation. He spoke English as it is spoken in England and I took bim for an Englishman, probably an employe in the civil service. In removing his cheap gray helmet I noticed that the top of his head as large as the palm of the hand was shaved. There was now no doubt in my mind concerning the vocation of my new companion. He informed me that he was a Roman Catholic priest, and furthermore, that he was a native of Switzerland, had been in India since he entered the priesthood 26 years ago, and that for eight years he had served as chaplain in the army, and was now on his way to visit a detachment of troops at Ahemabad. It further developed that our birthplaces in Switzerland were not 
far apart. It was a strange coincidence that I should find here in the wilds of India a countryman whose cradle was so near to mine. Rev. B. Jost, S.J.R.C.; chaplain, has spent his whole professional life in India as a missionary and chaplain. He has never taken a racation. He has seen the horrors of famine and the ravages of cholera, and other devastating epidemic diseases and has but once left his post when, stricken by fever and dysentery, his physician insisted on his being taken to Bombay to save his life. He was tenderly nursed by his brother priests, who for a long time had no hope that he would recover. His vigorous Helvetian constitution and determined will triumphed. $\mathrm{He}$ recovered and at once returned to his station. During the last famine, which extended over four years, he spent the money sent to him by friends in buying food, and dealt out rice and peas with his own hands during the hottest months of the year and was the means of saving 600 lives from starvation. He had exposed himself to all kinds of privations and dangers. In one day he dispatcherl four of the most deadly vipers in his yard and bungalow. All honor to such a brave, faithful servant of the Roman Catholic church.

\footnotetext{
"Calamity is an opportunity to show one's virtue."-Seneca. Ibid.

"Fire tries gold, misery tries brave men."-
}

ELEPHANTA CAVES.

The most interesting place I visited during my stay at Bombay was the Care Temple in Elephanta Island, one hour and a half by sailboat from the city. The elephant's island is about three miles in circumference, is forest-clad and interlaced with a very pretty creeper, which blossoms more than half of the year. The caves which in reality are a large Brahmin cave temple, are, according to Hindu tradition, 4,000 years old. There are fire cares, but the one usually visited is the Great Care, which is located about 250 feet above the level 


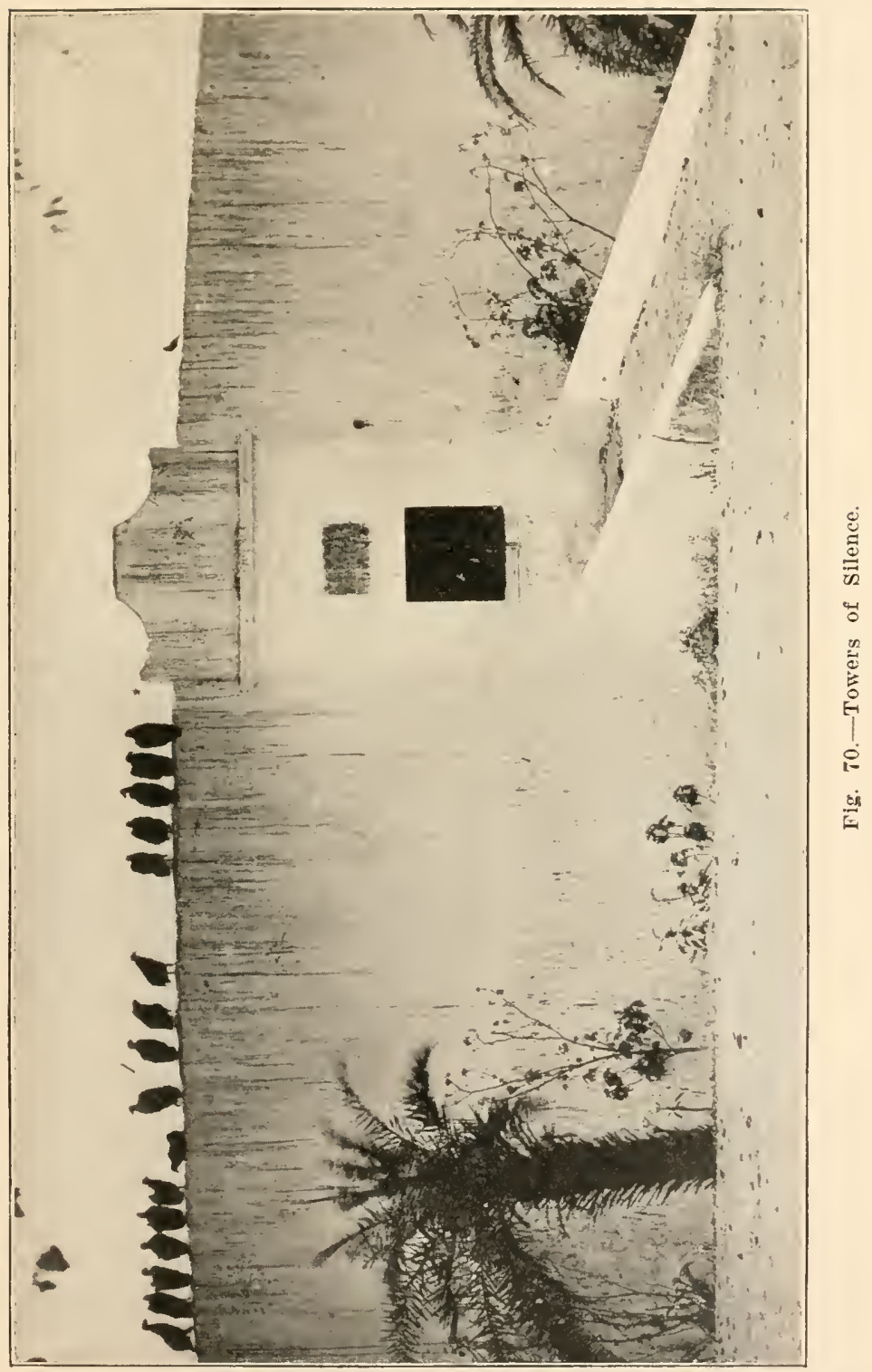



of the sea. It is hewn out of solid, hard rock. It is about 130 feet long and of the same width, and 17 feet high. At present it is only used as a place of worship on occasions of Shiva festivals, and in the middle of February a religious fair is held here. The sculptures which ornament the walls are cut out of the rock as well as the columns which support the stone ceiling. All of them show the ravages of time. Some of the colunmos are destroyed whole or in part, and large pieces have been split off from many of the mural figures.

'In short, do you not see stones even yield to the power of time; lofty towers fall to decay and rocks moulder away? Temples and statues of the gods go to ruin, nor can the gods themselves prolong their dates or give reprieve from fate."Lucretins.

Of the nine allegorical figures illustrating the Brahmin cult I will only briefly describe the central one which represents Brahma, the creator; that on the right is Vishnu, the preserver, and Shiva, the destroyer, on the left. This is the most elaborate and striking of the sculptures. Brahma's face is expressive of peace, kindness and reflection. If the artist of this exquisite work of art made any mistake it was in sparing stone in forming the thick everted lips. Brahma holds a lotus flower in his left hand; Shiva holds the deadly serpent, the cobra. 'The significance of the pomegranate is creation: that of the lotus flower preservation, and that of the ngly snake in threatening attitude, destruction. The figures on each side are supposed to be doorkeepers. each attended by a dwarf. The figures of this masterpiece of the sculptor's art of 4,000 years ago are well preserved and a study of them will satisfy any observer of the great skill of Indian artists of that remote period. In front of the open temple is a small tank, in the shallow water of which a number of pigmy frogs enjoyed their childish frolic. No one can visit this venerable care temple without becoming deeply impressed with the art of India long before the infant Moses was 
resuced from the crocodile infested Nile and long before liomulus was weaned from the breast of his ferocions wet nurse.

A GREWSOME CHARIEL HOLSE.

The Parsee people who came from P'ersia to India centuries ago, and of whom there are now about 100.000 in Bombay, are fire worshipers, and neither burn nor cremate their dead. They dispose of their lead by exposing them in a place wilere rultures can derour them in veace and safoty. The Towers of Silenee is the place where the hundreds of rultures are fed by the bodies of the rlead Parsee. 'These towers, five in nmmber. and the Fire Temple, the place of Parsec worship, are located on Malabar Hill. in elerated beantiful grounts which hare an area of orer $\% 5.000$ square vards. These gromds are surromnded hy a high stone wall and strangers are not admitter withont al special permit. (Fig. io.) The Towers of silence, the largest of which measures ?:6 feet in eircumfer-

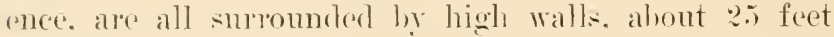
in height. and hare an opeuing on the gromol level. through which the dead bodies are carried. The corpse learers are the only persons allowed to enter the towers. The bodies of the deceased are laid in grooves around the well. which is in the center of the tower. The corpses of chilitren are laid in the center circle, those of the women in the second and those of the men in the onter ring. The bodies exposed in this manner are in a short time stripped of the flesh by the hundreds of vultures that are always in waiting for the arrival of the dead. and then the bonos are thrown into the well. where they are allowed to decompose. On the day I risited this grewsome spot I saw hundreds of these bird cannibals perehed in neighboring trees and on top of the towers. their gizzards eridently gorged with hnman flesh, motionless, llanging heads. drooping eyelids. sleeping. dreaming of the next feast on the first corpse of the 
community of lire worshipers. Should the interval bertween the lead marches be a long one, these cannibals of the air will be very hungry, a lively struggle will ensue for a share of the body exposed, fingers, toes and other parts of the body will be torn off and earried away to some quiet retreat, to be devoured at leisure. It is in this way that parts of the skelctons of the Parsee dead find their way into the dooryards, streets, gardens and on to house tops, grewsome relies of a grewsome practice of disposing of the dead.

In conchusion, it is to me a source of great pleasure to extend my sincerest thanks to the members of our noble profession whon I had the opportunity to meet and to whom I am deeply indebted for their uniform courtesy and charming hospitality.

S. S. Kroxprinz Wilielir, Harbor of New York, Oet. 11, 1904. 



UC SOUTHERN REGIONAL LIBRARY FACILITY

| || || || || || || || || || || || ||

AA $000217287 \quad 2$ 
